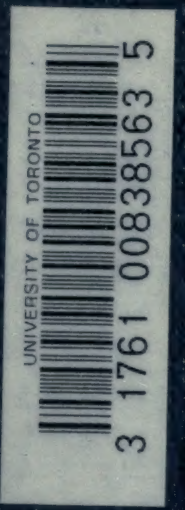




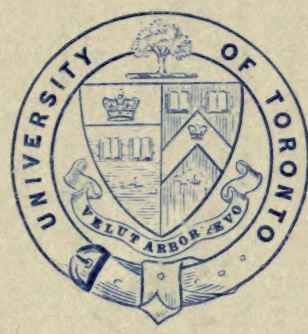

Dresentes to

\section{The Iíbrary}

of the

\section{University of Eoronto}

by

JBertram 1月. Davis

from the books of

the late $\mathfrak{L i o n e l}$ Davis, Ik.C. 
Digitized by the Internet Archive in 2008 with funding from Microsoft Corporation 



$$
446
$$

ESSAYS AND CRITICISMS 



\title{
ESSAYS AND CRITICISMS
}

\author{
BY \\ Jackeson
}

ST. GEORGE MIVART, F.R.S.

\section{IN TWO VOLUMES}

\author{
VOL. II
}

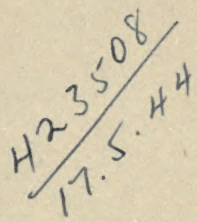

BOSTON

LITTLE, BROWN, AND COMPANY

1892 
QH

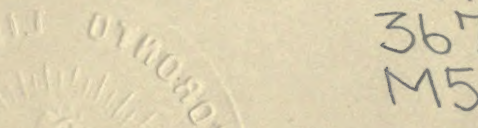

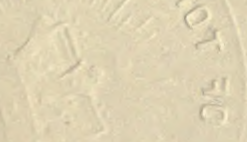

V. 2 


\section{NOTE}

THE author desires to express his thanks to the editors and publishers of the Quarterly, Edinburgh, Nineteenth Century, Fortnightly, Contemporary, and other Reviews, for their kind permission to republish the various articles from each of those periodicals which appear in these volumes. 



\section{CONTENTS}

2. Evolution axd its Consequences. A Reply to Professor HUXLEY . . . . . . 60

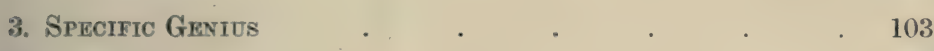

4. Herbert Spencer . . . . . . . 127

5. Prehistoric and Savage Max $\quad . \quad \ldots \quad . \quad$. 169

6. Address to the British Association, 1879 . . . 193

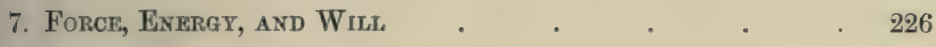

8. Likenesses ; or, Philosophical Anatomy . . . 250

9. Hermann Lotze and the Mechanical Philosophy • • 279

10. A Limit to Evoldtion - . . . . . . . . . 289

11. Organic Nature's Riddle . . . . . 315

12. What are Animals and Plants? . . . . 358

13. Weismann's Theories-The Beginning and End of Life $\quad 384-$

14. Eimer on Growth ANd Inheritance . . . . . 417 



\section{THE DESCENT OF MAN.}

The Descent of Man, and Selection in Relation to Sex. By Charles Darwin, M.A., F.R.S., \&c. 2 vols. London, 1871.

TN Mr. Darwin's last work we possess at length a complete 1 and thorough exposition of his matured views. He gives us the results of the patient labour of many years' unremitting investigation and of the application of a powerful and acute intellect, combined with an extraordinary active imagination, to an unequalled collection of most varied, interesting, and important biological data. In his earlier writings a certain reticence veiled, though it did not hide, his ultimate conclusions as to the origin of our own species; but now all possibility of misunderstanding or of a repetition of former disclaimers on the part of any disciple is at an end, and the entire and naked truth as to the logical consequences of Darwinism is displayed with a frankness which we had a right to expect from the distinguished author. What was but obscurely hinted in the Origin of Species is here fully and fairly stated in all its bearings and without disguise. Mr. Darwin has, in fact, 'crowned the edifice,' and the long looked for and anxiously awaited detailed statement of his views as to the human race is now unreservedly put before us.

We rise from the careful perusal of this book with mingled feelings of admiration and disappointment. The author's style is clear and attractive-clearer than in his earlier works-and his desire to avoid every kind of conscious misrepresentation is as conspicuous as ever. The

VOL. II. 
number of interesting facts brought forward is as surprising as is the ingenuity often displayed in his manipulation of them. Under these circumstances it is a most painful task to have to point out grave defects and serious shortcomings. Mr. Darwin, however, seems in his recent work even more than in his earlier productions to challenge criticism, and to have thrown out ideas and suggestions with a distinct view to their subsequent modification by others. It is but an act of fairness to call attention to this :-

'False facts,' says Mr. Darwin, 'are highly injurious to the progress of science, for they often long endure; but false views, if supported by some evidence, do little harm, as every one takes a salutary pleasure in proving their falseness ; and when this is done, one path towards error is closed and the road to truth is often at the same time opened.'-Descent of Man, vol. ii. p. 385 .

Although we are unable to agree entirely with Mr. Darwin in this remark, it none the less contains an undoubted truth. We cannot agree, because we feel that a false theory which keenly solicits the imagination, put forward by a writer widely and deservedly esteemed, and which reposes on a multitude of facts difficult to verify, skilfully interwoven, and exceedingly hard to unravel, is likely to be very prejudicial to science. Nevertheless, science cannot make progress without the action of two distinct classes of thinkers: the first consisting of men of creative genius, who strike out brilliant hypotheses, and who may be spoken of as 'theorisers' in the good sense of the word; the second, of men possessed of the critical faculty, and who test, mould into shape, perfect or destroy, the hypotheses thrown out by the former class.

Obviously important as it is that there should be such theorisers, it is also most important that criticism should clearly point out when a theory is really proved, when it is but probable, and when it is a mere arbitrary hypothesis. This is all the more necessary if, as may often and very 
easily happen, from being repeatedly spoken of, and being connected with celebrated and influential names, it is likely to be taken for very much more than it is really worth.

The necessity of caution in respect to this is clearly shown by Mr. Darwin's present work, in which 'sexual selection, from being again and again referred to as if it had been proved to be a vera causa, may readily be accepted as such by the uninstructed or careless reader. For many persons, at first violently opposed through ignorance or prejudice to Mr. Darwin's views, are now, with scarcely less ignorance and prejudice, as strongly inclined in their favour.

Mr. Darwin's recent work, supplementing and completing, as it does, his earlier publications, offers a good opportunity for reviewing his whole position. We shall thus be better able to estimate the value of his convictions regarding the special subject of his present inquiry. We shall first call attention to his earlier statements, in order that we may see whether he has modified his views, and, if so, how far and with what results. If he has, even by his own showing and admission, been over-hasty and seriously mistaken previously, we must be the more careful how we commit ourselves to his guidance now. We shall endeavour to show that Mr. Darwin's convictions have undergone grave modifications, and that the opinions adopted by him now are quite distinct from, and even subversive of the views he originally put forth. The assignment of the law of 'natural selection' to a subordinate position is virtually an abandonment of the Darwinian theory; for the one distinguishing feature of that theory was the all-sufficiency of 'natural selection.' Not the less, however, ought we to feel grateful to Mr. Darwin for bringing forward that theory, and for forcing on men's minds, by his learning, acuteness, zeal, perseverance, firmness, and candour, a recognition of the probability, if not more, of evolution and of the certainty of 
the action of 'natural selection.' For though the 'survival of the fittest' is a truth which readily presents itself to any one who considers the subject, and though its converse, the destruction of the least fit, was recognised thousands of years ago, yet to Mr. Darwin, and (through Mr. Wallace's reticence) to Mr. Darwin alone, is due the credit of having first brought it prominently forward and demonstrated its truth in a volume which will doubtless form a landmark in the domain of zoological science.

We find even in the third edition of his Origin of Species the following passages:- 'Natural selection can act only by taking advantage of slight successive variations; she can never take a leap, but must advance by short and slow steps' (p. 214). Again he says :- ' If it could be demonstrated that any complex organ existed, which could not possibly have been formed by numerous, successive, slight modifications, my theory would absolutely break down. But I can find out no such case' (p. 208). He adds :-

' Every detail of structure in every living creature (making some little allowance for the direct action of physical conditions) may be viewed, either as having been of special use to some ancestral form, or as being now of special use to the descendant of this form-either directly, or indirectly through the complex laws of growth ;' and 'if it could be proved that any part of the structure of any one species had been formed for the exclusive good of another species, it would annihilate my theory, for such could not have been produced through natural selection.'-P. 220 .

It is almost impossible for Mr. Darwin to have used words by which more thoroughly to stake the whole of his theory on the non-existence or non-action of causes of any moment other than natural selection. For why should such a phenomenon 'annihilate his theory'? Because the very essence of his theory, as originally stated, is to recognise only the conservation of minute variations directly beneficial to the 


\section{The Descent of Man}

creature presenting them, by enabling it to obtain food, escape enemies, and propagate its kind. But once more he says :-

'We have seen that species at any one period are not indefinitely variable, and are not linked together by a multitude of intermediate gradations, partly because the process of natural selection will always be very slow, and will act, at any one time, only on a very few forms ; and partly because the very process of natural selection almost implies the continual supplanting and extinction of preceding and intermediate gradations.'-P. 223.

Such are Mr. Darwin's earlier statements. At present we read as follows :-

'I now admit, after reading the essay by Nageli on plants, and the remarks by various authors with respect to animals, more especially those recently made by Professor Broca, that in the earlier editions of my Origin of Species I probably attributed too much to the action of natural selection or the survival of the fittest. . . . . I had not formerly sufficiently considered the existence of many structures which appear to be, as far as we can judge, neither beneficial nor injurious; and this I believe to be one of the greatest oversights as yet detected in my work.'-Descent of Man, vol. i. p. 152.

A still more remarkable admission is that in which he says, after referring to the action of both natural and sexual selection :-

'An unexplained residuum of change, perhaps a large one, must be left to the assumed action of those unknown agencies, which occasionally induce strongly marked and abrupt deviations of structure in our domestic productions.'-Vol. i. p. 154.

But perhaps the most glaring contradiction is presented by the following passage:-

'No doubt man, as well as every other animal, presents structures which, as far as we can judge with our little knowledge, are not now of any service to him, nor have been so during any former period of his existence, either in relation to his general conditions of life, or of one sex to the other. Such structures cannot be accounted for by any 
form of selection, or by the inherited effects of the use and disuse of parts. We know, however, that many strange and strongly marked peculiarities of structure occasionally appear in our domesticated productions; and if the unknown causes which produce them were to act more uniformly, they would probably become common to all the individuals of the species.'-Vol. ii. p. 387.

Mr. Darwin, indeed, seems now to admit the existence of internal, innate powers, for he goes on to say:-

'We may hope hereafter to understand something about the causes of such occasional modification, especially through the study of monstrosities. .... In the greater number of cases we can only say that the cause of each slight variation and of each monstrosity lies much more in the nature or constitution of the organism ${ }^{1}$ than in the nature of the surrounding conditions; though new and changed conditions certainly play an important part in exciting organic changes of all kinds.'

Also, in a note (vol. i. p. 223), he speaks of 'incidental results of certain unknown differences in the constitution of the reproductive system.'

Thus, then, it is admitted by our author that we may have 'abrupt, strongly marked' changes, 'neither beneficial nor injurious' to the creatures possessing them, produced by 'unknown agencies' lying deep in 'the nature or constitution of the organism,' and which, if acting uniformly, would 'probably' modify similarly 'all the individuals of a species.' If this is not an abandonment of 'natural selection,' it would be difficult to select terms more calculated to express it. But Mr. Darwin's admissions of error do not stop here. In the fifth edition of his Origin of Species (p. 104) he says : 'Until reading an able and valuable article in the North British Review (1867), I did not appreciate how rarely single variations, whether slight or strongly marked, could be perpetuated.' Again: he was formerly 'inclined to lay much

${ }^{1}$ The italics in the quotations from Mr. Darwin's book in this article are, in almost all cases, ours, and not the author's. 
stress on the principle of protection, as accounting for the less bright colours of female birds' (Descent of Man, vol. ii. p. 198); but now he speaks as if the correctness of his old conception of such colours being due to protection was unlikely. 'Is it probable,' he asks, 'that the head of the female chaffinch, the crimson on the breast of the female bullfinch, - the green of the female chaffinch,-the crest of the female golden-crested wren, have all been rendered less bright by the slow process of selection for the sake of protection? I cannot think so' (vol. ii. p. 176).

Once more Mr. Darwin shows us (vol. i. p. 125) how he has been over-hasty in attributing the development of certain structures to reversion. He remarks, 'In my Variations of Animals under Domestication (vol. ii. p. 57) I attributed the not very rare cases of supernumerary mammæ in women to reversion. But Professor Preyer states that mammce erraticce have been known to occur in other situations, even on the back; so that the force of my argument is greatly weakened or perhaps quite destroyed.'

Finally, we have a postscript at the beginning of the second volume of the Descent of Man which contains an avowal more remarkable than even the passages already cited. He therein declares :-

- ' I have fallen into a serious and unfortunate error in relation to the sexual differences of animals, in attempting to explain what seemed to me a singular coincidence in the late period of life at which the necessary variations have arisen in many cases, and the late period at which sexual selection acts. The explanation given is wholly erroneous, as I have discovered by working out an illustration in figures.'

While willingly paying a just tribute of esteem to the candour which dictated these several admissions, it would be idle to dissemble, and disingenuous not to declare, the amount of distrust with which such repeated over-hasty 
conclusions and erroneous calculations inspire us. When their author comes before us anew, as he now does, with opinions and conclusions still more startling, and calculated in a yet greater degree to disturb convictions reposing upon the general consent of the majority of cultivated minds, we may well pause before we trust ourselves unreservedly to a guidance which thus again and again declares its own reiterated fallibility. Mr. Darwin's conclusions may be correct, but we feel we have now indeed a right to demand that they shall be proved before we assent to them? and that since what Mr. Darwin before declared 'must be' he now admits not only to be unnecessary but untrue, we may justly regard with extreme distrust the numerous statements and calculations which, in the Descent of Man, are avowedly recommended by a mere ' may be.' This is the more necessary, as the author, starting at first with an avowed hypothesis, constantly asserts it as an undoubted fact, and claims for it, somewhat in the spirit of a theologian, that it should be received as an article of faith. Thus the formidable objection to Mr. Darwin's theory, that the great break in the organic chain between man and his nearest allies, which cannot be bridged over by any extinct or living species, is answered simply by an appeal 'to a belief in the general principle of evolution' (vol. i. p. 200), or by a confident statement that 'we have every reason to believe that breaks in the series are simply the result of many forms having become extinct' (vol. i. p. 187). So, in like manner, we are assured that 'the early progenitors of man were, no doubt once covered with hair, both sexes having beards; their ears were pointed and capable of movement; and their bodies were provided with a tail, having the proper muscles' (vol. i. p. 206). And, finally, we are told, with a dogmatism little worthy of a philosopher, that, 'unless we wilfully close our eyes,' we must recognise our parentage (vol. i. p. 213). 
These are hard words; and, even at the risk of being accused of wilful blindness, we shall now proceed, with an unbiassed and unprejudiced mind, to examine carefully the arguments upon which Mr. Darwin's theory rests. Must we acknowledge that ' $m a n$ with all his noble qualities, with sympathy which feels for the most debased, with benevolence which extends not only to other men but to the humblest living creature, with his god-like intellect which has penetrated into the movements and constitution of the solar system,' must we acknowledge that man 'with all these exalted powers' is descended from an Ascidian? Is this a scientific truth resting on scientific evidence, or is it to be classed with the speculations of a bygone age ?

With regard to the Origin of Man, Mr. Darwin considers that both 'natural selection' and 'sexual selection' have acted. We need not on the present occasion discuss the action of natural selection; but it will be necessary to consider that of 'sexual 'selection' at some length. It plays a very important part in the 'descent of man,' according to Mr. Darwin's views. He maintains that we owe to it our power of song and our hairlessness of body, and that also to it is due the formation and conservation of the various races and varieties of the human species. In this matter then we fear we shall have to make some demand upon our reader's patience. 'Sexual selection' is the corner-stone of $\mathrm{Mr}$. Darwin's theory. It occupies three-fourths of his two volumes; and unless he has clearly established this point, the whole fabric falls to the ground. It is impossible, therefore, to review the book without entering fully into the subject, even at the risk of touching upon some points which, for obvious reasons, we should have preferred to pass over in silence.

Under the head of 'sexual selection' Mr. Darwin includes two very distinct processes. One of these consists in the action of superior strength or activity, by which one male 
succeeds in obtaining possession of mates and in keeping away rivals. This is, undoubtedly, a vera causa; but may be more conveniently reckoned as one kind of 'natural selection' than as a branch of 'sexual selection.' The second process consists in alleged preference or choice, exercised freely by the female, in favour of particular males on account of some attractiveness or beauty of form, colour, odour, or voice, which such males may possess. It is this second kind of 'sexual selection' (and which alone deserves the name) that is important for the establishment of Mr Darwin's views, but the efficiency of its action has to be proved.

Now, to prove the existence of such a power of choice Mr. Darwin brings forward a multitude of details respecting the sexual phenomena of animals of various classes; but it is the class of birds which is mainly relied on to afford evidence in support of the exercise of this power of choice by female animals. We contend, however, that not only is the evidence defective even here, but that much of his own evidence is in direct opposition to his views. While the unquestionable fact, that male sexual characters (horns, mane, wattles, etc., etc.) have been developed in many cases where sexual selection has certainly not acted, renders it probable, a priori, that the unknown cause which has operated in these numerous cases has operated in those instances also which seem to favour the hypothesis supported by Mr. Darwin. Still he contends that the greater part of the beauty and melody of the organic world is due exclusively to this selective process, by which, through countless generations, the tail of the peacock, the throat of the humming-bird, the song. of the nightingale, and the chirp of the grasshopper have been developed by females, age after age, selecting for their mates males possessing in a more and more perfect degree characters which must thus have been continually and constantly preferred. 


\section{The Descent of Man}

Yet, after all, Mr. Darwin concedes in principle the very point in dispute, and yields all for which his opponents need argue, when he allows that beautiful and harmonious variations may occur spontaneously and at once, as in the dark or spangled bars on the feathers of Hamburg fowls (Descent of Man, vol. i. p. 281). For what difference is there, other than mere difference of degree, between the spontaneous appearance of a few beautiful new feathers with harmonious markings, and the spontaneous appearance of a whole beautiful clothing like that of the Tragopans?

Again, on Mr. Darwin's own showing, it is manifest that male sexual characters, such as he would fain attribute to sexual selection, may arise without any such action whatever. Thus he tells us, 'There are breeds of the sheep and goat in which the horns of the male differ greatly in shape from those of the female'; and 'with tortoise-shell cats, the females alone, as a general rule, are thus coloured, the males being rusty-red' (vol. i. p. 283). Now, if these cats were only known in a wild state, Mr. Darwin would certainly bring them forward amongst his other instances of alleged sexual selection, though we now know the phenomenon is not due to any such cause. A more striking instance, however, is the following:- 'With the pigeon, the sexes of the parent species do not differ in any external character; nevertheless, in certain domesticated breeds the male is differently coloured from the female. The wattle in the English carrierpigeon and the crop in the pouter are more highly developed in the male than in the female'; and 'this has arisen, not from, but rather in opposition to, the wishes of the breeder'; which amounts to a positive demonstration that sexual characters may arise spontaneously, and, be it noted, in the class of birds!

The uncertainty which besets these speculations of Mr. Darwin is evident at every turn. What at first could be 
thought a better instance of sexual selection than the light of the glowworm, exhibited to attract her mate? Yet the discovery of luminous larvæ, which of course have no sexual action, leads Mr. Darwin to observe: 'It is very doubtful whether the primary use of the light is to guide the male to the female' (vol. i. p. 345). Again, as to certain British fieldbugs, he says: 'If in any species the males had differed from the females in an analogous manner, we might have been justified in attributing such conspicuous colours to sexual selection with transference to both sexes' (vol. i. p. 350). As to the stridulating noises of insects (which is assumed to be the result of sexual selection), Mr. Darwin remarks of certain Neuroptera:- 'It is rather surprising that both sexes should have the power of stridulating, as the male is winged and the female wingless ' (vol. i. p. 366); and he is again surprised to find that this power is not a sexual character in many Coleoptera (vol. i. p. 382).

Moths and butterflies, however, are the insects which Mr. Darwin treats of at the greatest length in support of sexual selection. Yet even here he supplies us with positive evidence that in certain cases beauty does not charm the female. He tells us :-

'Some facts, however, are opposed to the belief that female butterflies prefer the more beautiful males; thus, as I have been assured by several observers, fresh females may frequently be seen paired with battered, faded, or dingy males.'-Vol. i. p. 400.

As to the Bombycidæ, he adds :-

'The females lie in an almost torpid state, and appear not to evince the least choice in regard to their partners. This is the case with the common silk-moth (B. mori). Dr. Wallace, who has had such immense experience in breeding Bombyx cynthia, is convinced that the females evince no choice or preference. He has kept above three hundred of these moths living together, and has often found the most vigorous females mated with stunted males.' 
Nevertheless, we do not find, for all this, any defect of colour or markings, for, as Mr. Alfred Wallace observes (Nature, March 15th, 1871, p. 182), 'the Bombyces are amongst the most elegantly coloured of all moths.'

Mr. Darwin gives a number of instances of sexual characters, such as horns, spines, etc., in beetles and other insects; but there is no fragment of evidence that such structures are in any way due to feminine caprice. Other structures are described which doubtless do aid the sexual act, as the claws of certain Crustacea; but these are often of such size and strength (e.g. in Callianassa and Orchestia) as to render any power of choice on the part of the female in the highest degree incredible.

Similarly with the higher classes, i.e. Fishes, Reptiles, and Beasts, we have descriptions and representations of a number of sexual peculiarities, but no evidence whatever that such characters are due to female selection. Often we have statements which conflict strongly with a belief in any such action. Thus, e.g., Mr. Darwin quotes Mr. R. Buist, Superintendent of Fisheries, as saying that male salmon

'are constantly fighting and tearing each other on the spawningbeds, and many so injure each other as to cause the death of numbers, many being seen swimming near the banks of the river in a state of exhaustion, and apparently in a dying state. . . The keeper of Stormontfield found in the northern Tyne about three hundred dead salmon, all of which, with one exception, were males; and he was convinced that they had lost their lives by fighting.'- Vol. ii. p. 3 .

The female's choice must here be much limited, and the only kind of sexual selection which can operate is that first kind, determined by combat, which, we before observed, must rather be ranked as a kind of 'natural selection.' Even with regard to this, however, we may well hesitate, when Mr. Darwin tells us, as he does, that seeing the habitual contests of the males, 'it is surprising that they have not gene- 
rally become, through the effects of sexual selection, larger and stronger than the females'; and this the more as 'the males suffer from their small size,' being 'liable to be devoured by the females of their own species' (vol. ii. p. 7). The cases cited by our author, with regard to fishes, do not even tend to prove the existence of sexual selection, and the same may be said as to the numerous details given by him about reptiles and amphibians. Nay, rather the facts are hostile to his views. Thus, he says himself, 'It is surprising that frogs and toads should not have acquired more stronglymarked sexual differences; for though cold-blooded, their passions are strong' (vol. ii. p. 26). But he cites a fact, than which it would be difficult to find one less favourable to his cause. He adds, 'Dr. Günther informs me that he has several times found an unfortunate female toad dead and smothered from having been so closely embraced by three or four males.' If female selection was difficult in the case of the female salmon, it must be admitted to have been singularly infelicitous to the female toad.

We will now notice some facts brought forward by Mr. Darwin with regard to beasts. And first, as to the existence of choice on the part of the females, it may be noted that 'Mr. Blenkiron, the greatest breeder of race-horses in the world, says that stallions are so frequently capricious in their choice, rejecting one mare and without any apparent cause taking to another, that various artifices have to be habitually used.' He has never known a mare to reject a horse; though this has occurred in Mr. Wright's stable.

Some of the most marked sexual characters found amongst mammals are those which exist in apes. These are abundantly noticed by Mr. Darwin, but his treatment of them seems to show his inability to bring them within the scope of his theory.

It is well known that certain apes are distinguished by 
the lively colours or by the peculiarities as to hair possessed by the males, while it is also notorious that their vastly superior strength of body and length of fang would render resistance on the part of the female difficult and perilous, even were we to adopt the utterly gratuitous supposition, that at seasons of sexual excitement the female shows any disposition to coyness. Mr. Darwin has no facts to bring forward to prove the exercise of any choice on the part of female apes, but gives in support of his views the following remarkable passage :-

'Must we attribute to mere purposeless variability in the male all these appendages of hair and skin ? It cannot be denied that this is possible ; for, with many domesticated quadrupeds, certain characters, apparently not derived through reversion from any wild parentform, have appeared in, and are confined to, the males, or are more largely developed in them than in the females-for instance, the hump in the male zebu-cattle of India, the tail in fat-tailed rams, the arched outline of the forehead in the males of several breeds of sheep, the mane in the ram of an African breed; and, lastly, the mane, long hairs on the hinder legs, and the dewlap in the male alone of the Berbura goat.'-Vol. ii. p. 284.

If these are due, as is probable, to simple variability, then, he adds-

'it would appear reasonable to extend the same view to the many analogous characters occurring in animals under a state of nature. Nevertheless, I cannot persuade myself that this view is applicable in many cases, as in that of the extraordinary development of hair on the throat and fore-legs of the male Ammotragus, or of the immense beard of the Pithecia (monkey).'-Vol. ii. p. 285.

But one naturally asks, Why not? Mr. Darwin gives no reason beyond that (if such it may be called) implied in the gratuitous use of the epithet 'purposeless' in the passage cited, and to which we shall return.

In the Rhesus monkey, the female appears to be more vividly coloured than the male; therefore Mr. Darwin infers 
(grounding his inference on alleged phenomena in birds) that sexual selection is reversed, and that in this case the male selects. This hypothetical reversion of a hypothetical process to meet an exceptional case will appear to many rash indeed, when they reflect that as to teeth, whiskers, general size, and superciliary ridges this monkey 'follows the common rule of the male excelling the female' (vol. ii. p. 294).

To turn now to the class on which Mr. Darwin especially relies, we shall find that even birds supply us with numerous instances which conflict with his hypothesis. Thus, speaking of the battling of male waders, our author tells us:- 'Two were seen to be thus engaged for half an hour, until one got hold of the head of the other, which would have been killed had not the observer interfered; the female all the time looking on as a quiet spectator' (vol. ii. p. 41). As these battles must take place generally in the absence of spectators, their doubtless frequently fatal termination must limit greatly the power of selection Mr. Darwin attributes to the females. The same limit is certainly imposed in the majority of Gallinaceous birds, the cocks of which fight violently; and there can be little doubt but that, as an almost invariable rule, the victorious birds mate with the comparatively passive hens.

Again, how can we explain, on Mr. Darwin's hypothesis, the existence of distinguishing male sexual marks, where it is the male and not the female bird which selects? Yet the wild turkey-cock, a distinguished bird enough, is said by $\mathrm{Mr}$. Darwin (vol. ii. p. 207) to be courted by the females; and he quotes (vol. ii. p. 120) Sir R. Heron as saying, 'that with peafowl, the first advances are always made by the female.' And of the capercailzie he says, 'the females flit round the male while he is parading, and solicit his attention.'

But though, of course, the sexual instinct always seeks its gratification, does the female ever select a particular 
plumage? The strongest instance given by Mr. Darwin is as follows :-

' Sir R. Heron during many years kept an account of the habits of the peafowl, which he bred in large numbers. He states that the hens have frequently great preference for a particular peacock. They were all so fond of an old pied cock, that one year, when he was confined though still in view, they were constantly assembled close to the trellice-walls of his prison, and would not suffer a japanned peacock to touch them. On his being let out in the autumn, the oldest of the hens instantly courted him, and was successful in her courtship. The next year he was shut up in a stable, and then the hens all courted his rival. This rival was a japanned or black-winged peacock, which to our eyes is a more beautiful bird than the common kind.'-Vol. ii. p. 119.

Now no one disputes as to birds showing preferences one for another, but it is quite a gratuitous suggestion that the pied plumage of the venerable paterfamilias was the charm which attracted the opposite sex; and even if such were the case, it would seem to prove (from Mr. Darwin's concluding remark) either that the peahen's taste is so different from ours, that the peacock's plumage could never have been developed by it, ur (if the taste of these peahens was different. from that of most peahens) that such is the instability of a vicious feminine caprice, that no constancy of coloration could be produced by its selective action.

Mr. Darwin bases his theory of sexual selection greatly on the fact that the male birds display the beauty of their plumage with elaborate parade and many curious and uncouth gestures. But this display is not exclusively used in attracting and stimulating the hens. Thus he admits that ' the males will sometimes display their ornaments when not in the presence of the females, as occasionally occurs with the grouse at their balz-places, and as may be noticed with the peacock; this latter bird, however, evidently wishes for a spectator of some kind, and will show off his finery, as I VOL. II. 
have often seen, before poultry or even pigs' (vol. ii. p. 86). Again, as to the brilliant Rupicola crocea, Sir R. Schomburgk says: 'A male was capering to the apparent delight of several others' (vol. ii. p. 87).

From the fact of ' display' Mr. Darwin concludes that 'it is obviously probable that the females appreciate the beauty of their suitors' (vol. ii. p. 111). Our author, however, only ventures to call it 'probable,' and he significantly adds: 'It is, however, difficult to obtain direct evidence of their capacity to appreciate beauty.' And again he says of the hen bird: 'It is not probable that she consciously deliberates; but she is most excited or attracted by the most beautiful, or melodious, or gallant males' (vol. ii. p. 123). No doubt the plumage, song, etc., all play their parts in aiding the various processes of life; but to stimulate the sexual instinct, even supposing this to be the object, is one thing-to supply the occasion for the exercise of a power of choice is quite another. Certainly we cannot admit what Mr. Darwin affirms (vol. ii. p. 124), that an 'even occasional preference by the female of the more attractive males would almost certainly lead to their modification.'

A singular instance is given by Mr. Darwin (vol. ii. p. 111) in support of his view, on the authority of Mr. J. Weir. It is that of a bullfinch which constantly attacked a reed-bunting, newly put into the aviary; and this attack is attributed to a sort of jealousy on the part of the blackheaded bullfinch of the black head of the bunting. But the bullfinch could hardly be aware of the colour of the top of its own head!

$\mathrm{Mr}$ Wallace accounts for the brilliant colours of caterpillars and many birds in another way. The caterpillars which are distasteful, must have gained if 'some outward sign indicated to their would-be destroyer that its prey was a disgusting morsel.' As to birds, he believes that brilliance of plumage is developed where not hurtful, and that the gener- 
ally more sober plumage of the hens has been produced by natural selection, killing off the more brilliant ones exposed during incubation to trying conditions.

Now as Mr. Wallace disposes of Mr. Darwin's views by his objections, so Mr. Darwin's remarks tend to refute Mr. Wallace's positions, and the result seems to point to the existence. of some unknown, innate, and internal law which determines at the same time both coloration and its transmission to either or to both sexes. At the same time these authors, indeed, show the harmony of natural laws and processes one with another, and their mutual interaction and aid.

It cannot be pretended that there is any evidence for sexual selection except in the class of Birds. Certain of the phenomena which Mr. Darwin generally attributes to such selection must be due, in some other classes, to other causes, and there is no proof that sexual selection acts, even amongst birds.

But in other classes, as we have seen, sexual characters are as marked as they are in the feathered group. $\mathrm{Mr}$. Darwin, indeed, argues that birds select, and assumes that their sexual characters have been produced by such sexual selection, and that, therefore, the sexual characters of beasts have been similarly evolved. But we may turn the argument round and say that sexual characters not less strongly marked exist in many beasts, reptiles, and insects, which characters cannot be due to sexual selection; that it is, therefore, probable the sexual characters of birds are not due to sexual selection either, but that some unknown internal cause has equally operated in each case. The matter, indeed, stands thus: Of animals possessing sexual characters there are some in which sexual selection cannot have acted; others in which it may possibly have acted; others again in which, according to Mr. Darwin, it has certainly acted. It is somewhat singular reasoning to deduce from these facts the con- 
clusion that sexual selection is the one universal cause of sexual characters, when similar effects to those which it is supposed to cause take place in its absence.

But, indeed, what are the data on which Mr. Darwin relies as regards birds? As before said, they are 'display' by the males, the 'greater brilliancy and ornamentation of these,' and the 'occasional preference' by females in confinement for particular inales. Is there here any sufficient foundation for such a superstructure? In the first place, in insects, e.g. butterflies, we have often many brilliant males crowding in pursuit of a single female. Yet, as Mr. Wallace justly observes, 'Surely the male who finally obtains the female will be either the most vigorous, or the strongestwinged, or the most patient--the one who tires out or beats off the rest.' Similarly in birds strength and perseverance will, no doubt, generally reward the suitor possessing those qualities. Doubtless, also, this will generally be the most beautiful or most melodious; but this will simply be because extra beauty of plumage or of song, will accompany supereminent vigour of constitution and fulness of vitality. What has been before said as to the fierce combats of cock-birds must be borne in mind.

But that internal spontaneous powers are sufficient to produce all the most varied or bizarre sexual characters which any birds exhibit, is actually demonstrated by the class of insects, especially caterpillars, which from their sexless, undeveloped state can have nothing to do with the kind of selection Mr. Darwin advocates. Yet amongst caterpillars we not only find some ornamented with spots, bands, stripes, and curious patterns, 'perfectly definite in character and of the most brilliantly contrasted hues. We have also many ornamental aprendages; beautiful fleshy tubercles or tentacles, hard spines, beautifully coloured hairs arranged in tufts, brushes, starry clusters, or long pencils, and horns on 
the head and tail, either single or double, pointed or clubbed.' Mr. Wallace adds, 'Now, if all these beautiful and varied ornaments can be produced and rendered constant in each species by some unknown cause quite independent of sexual selection, why cannot the same cause produce the colours and many of the ornaments of perfect insects?'-we may also add, the colours and ornaments of all other animals, including birds ?

There is, however, another reason which induces $\mathrm{Mr}$. Darwin to accept sexual selection; and it is probably this which, in his mind, mainly gives importance to the facts mentioned as to the plumage and motions of birds. He says of 'display': 'It is incredible that all this display should be purposeless' (vol. ii. p. 399); and again (vol. ii. p. 93), he declares that any one who denies that the female Argus pheasant can appreciate the refined beauty of the plumage of her mate ' will be compelled to admit that the extraordinary attitudes assumed by the male during the act of courtship, by which the wonderful beauty of his plumage is fully displayed, are purposeless; and this is a conclusion which I for one will never admit.' It seems then that it is this imaginary necessity of attributing purposelessness to acts, which determines Mr. Darrin to attribute that peculiar and special purpose to birds' actions which he does attribute to them. But surely this difficulty is a mere chimæra. Let it be granted that the female does not select; yet the display of the male may be useful in supplying the necessary degree of stimulation to her nervous system, and to that of the male. Pleasurable sensation, perhaps very keen in intensity, may thence result to both. There would be no difficulty in suggesting yet other purposes if we were to ascend into higher speculative regions. Mr. Darwin has given us in one place a very remarkable passage; he says :-

'With respect to female birds feeling a preference for particular 
males, we must bear in mind that we can judge of choice being exerted, only by placing ourselves in imagination in the same position. If an inhabitant of another planet were to behold a number of young rustics at a fair, courting and quarrelling over a pretty girl, like birds at one of their places of assemblage, he would be able to infer that she had the power of choice only by observing the eagerness of the wooers to please her and to display their finery.'-Vol. ii. p. 122 .

Now here it must be observed that, as is often the case, Mr. Darwin assumes the very point in dispute, unless he means by 'power of choice' mere freedom of physical power. If he means an internal, mental faculty of choice, then the observer could attribute such power to the girl only if he had reason to attribute to the rustics an intellectual and moral nature similar in kind to that which he possessed himself. Such a similarity of nature Mr. Darwin, of course, does attribute to rational beings and to brutes; but those who do not agree with him in this, would require other tests than the presence of ornaments and the performance of antics and gestures unaccompanied by any evidence of the faculty of articulate speech.

Such, then, is the nature of the evidence on which sexual selection is supposed to rest. To us the action of sexual selection scarcely seems more than a possibility, the evidence rarely raising it to probability. It cannot be a 'sufficient cause' to account for the phenomena which it is intended to explain, nor can it even claim to be taken as a vera causa at all. Yet $\mathrm{Mr}$ Darwin again and again speaks as if its reality and cogency were indisputable.

As to the alleged action of natural selection on our own species we may mention two points.

First, as to the absence of hair. This is a character which Mr. Darwin admits cannot be accounted for by ' natural selection,' because manifestly not beneficial; it is therefore 
attributed to 'sexual selection,' incipient man being supposed to have chosen mates with less and less hairy bodies; and the possibility of such action is thought by Mr. Darwin to be supported by the fact that certain monkeys have parts of the body naked. Yet it is a fact that the higher apes have not this nakedness, or have it in a much smaller degree.

Secondly, as to the races of mankind, Mr. Darwin's theory, indeed, requires the alternation of constancy and caprice to account for the selection and the conservation of marked varieties. In order that each race may possess and preserve its own ideal standard of beauty, we require the truth of the hypothesis that 'certain tastes may in the course of time become inherited'; and yet Mr. Darwin candidly admits (vol. ii. p. 353), 'I know of no evidence in favour of this belief.' On the other hand, he says (p. 370), 'As soon as tribes exposed to different conditions came to vary, each isolated tribe would form for itself a slightly different standard of beauty,' which 'would gradually and inevitably be increased to a greater and greater degree.' But why have not the numerous tribes of North American Indians diverged from each other more conspicuously, inhabiting, as they do, such different climates, and surrounded by such diverse conditions?

Again, far from each race being bound in the trammels of its own features, all cultivated Europeans, whether Celts, Teutons, or Slavs, agree in admiring the Hellenic ideal as the highest type of human beauty.

We may now pass on to the peculiarities of man's bodily frame, and the value and the signification of the resemblances presented by it to the various structures which are found to exist in lower members of the animal kingdom.

Mr. Darwin treats us to a very interesting account, not only of man's anatomy, but also of the habits, diseases, and parasites (internal and external) of man, together with the 
process of his development. He points out (vol. i. p. 11) not only the close similarity even of cerebral structure between man and apes, but also how the same animals are 'liable to many of the same non-contagious diseases as we are; thus Rengger, who carefully observed for a long time the Cebus Azarœ in its native land, found it liable to catarrh, with the usual symptons, and which when often recurrent, led to consumption. These monkeys suffered also from apoplexy, inflammation of the bowels, and cataract in the eye. The younger ones, when shedding their milk-teeth, often died from fever. Medicines produced the same effect on them as on us. Many kinds of monkeys have a strong taste for tea, coffee, and spirituous liquors; they will also, as I have myself seen, smoke tobacco with pleasure.' He also tells us of baboons which, after taking too much beer, 'on the following morning were very cross and dismal, held their aching heads with both hands, and wore a most pitiable expression: when beer or wine was offered them, they turned away with disgust, but relished the juice of lemons.' He notices, besides, the process of development in man with the transitory resemblances it exhibits to the immature conditions of other animals, and he mentions certain muscular abnormalities.

Mr. Darwin also brings forward an observation of $\mathrm{Mr}$. Woolner, the sculptor, as to a small projection of the helix or outermost fold of the human ear, which projection 'we may safely conclude' to be 'a vestige of formerly pointed earswhich occasionally re-appears in man' (vol. i. p. 23). Very many other interesting facts are noted which it would be superfluous here to recapitulate. It is, however, in connection with man's bodily structure and its resemblances, that we have observed slight errors on the part of Mr. Darwin, which it may be as well to point out; though it should be borne in mind that he does not profess to be in any sense an 
anatomist. Thus, at vol. i. p. 28 , he mistakes the supracondyloid foramen of the humerus for the inter-condyloid perforation. Did the former condition frequently occur in man - as, through this mistake, he asserts -it would be remarkable indeed, as it is only found in the lower monkeys and not in the higher. A more singular mistake is that of the malar bone for the premaxilla (vol. i. p. 124).

To return to the bodily and other characters enumerated at such length by Mr. Darwin. They may, and doubtless they will, produce a considerable effect on readers who are not anatomists, but in fact the whole and sole result is to show that man is an animal. That he is such is denied by no one, but has been taught and accepted since the time of Aristotle. We remember on one occasion meeting at a dinnertable a clever medical man of materialistic views. He strongly impressed the minds of some laymen present by an elaborate statement of the mental phenomena following upon different injuries, or diseased conditions of different parts of the brain, until one of the guests remarked as a climax, 'Yes; and when the brain is entirely removed the mental phenomena cease altogether' - the previous observations having only brought out vividly what no one denied, viz., that during this life a certain integrity of bodily structure is requisite for the due exercise of the mental powers. Thus Mr. Darwin's remarks are merely an elaborate statement of what all admit, namely, that man is an animal. They further imply, however, that he is no more than an animal, and that the mode of origin of his visible being must be the mode of his origin as a whole-a conclusion of which we should not question the legitimacy, if we could accept Mr. Darwin's views of man's mental powers.

All that can be said to be established by our author is, that if the various kinds of lower animals have been evolved one from the other by a process of natural generation or 
evolution, then it becomes highly probable $\dot{a}$ priori that man's body has been similarly evolved; but this, in such a case, becomes equally probable from the admitted fact that he is an animal at all.

The evidence for such a process of evolution of man's body amounts, however, only to an à priori probability, and might be reconciled with another mode of origin if there were sufficient reason (of another kind) to justify a belief in such other mode of origin. Mr. Darwin says:-' It is only our natural prejudice, and that arrogance which made our forefathers declare that they were descended from demigods, which leads us to demur to this conclusion' (vol. i. p. 32). But this is not the case ; for many demur to his conclusion because they believe that to accept his view would be to contradict other truths which to them are far more evident.

He also makes the startling assertion that to take any other view than his as to man's origin, 'is to admit that our own structure and that of all the animals around us, is a mere snare laid to entrap our judgment' (vol. i. p. 32). Mr. Darwin is, we are quite sure, far enough from pretending that he has exhausted the possibilities of the case, and yet could anything but a conviction that the whole field had been explored exhaustively justify such an assertion? If, without such a conviction, it were permissible so to dogmatise, every theoriser who had attained to a plausible explanation of a set of phenomena might equally make use of the assertion, and say, until a better explanation was found, that to doubt him would be to attribute duplicity to the Almighty.

In tracing man's origin Mr. Darwin is again betrayed into slight inaccuracies. Thus, in combating a position, advanced in the Quarterly Review, ${ }^{1}$ that the hands of apes had been

${ }^{1}$ See that for April 1869, p. 392. 
preformed (with a view to man) in a condition of perfection beyond their needs, he says :-

' On the contrary, I see no reason to doubt that a more perfectly constructed hand would have been an advantage to them, provided, and it is important to note this, that their hands had not thus been rendered less well adapted for climbing trees. We may suspect that a perfect hand would have been disadvantageous for climbing; as the most arboreal monkeys in the world, namely Ateles in America and Hylobates in Asia, either have their thumbs much reduced in size and even rudimentary, or their fingers partially coherent, so that their hands are converted into grasping-hooks.'-Vol. i. p. 140.

In a note, Mr. Darwin refers to the Syndactyle Gibbon as having two of the digits coherent. But these digits are not, as he supposes, digits of the hand but toes. Moreover, though doubtless the Gibbons and spider-monkeys are admirably organised for their needs, yet it is plain that a well developed thumb is no impediment to climbing, for the strictly arboreal Lemurs are exceedingly well furnished in this respect. Again he says (vol. i. p. 143) of the Gibbons, that they, "without having been taught, can walk or run upright with tolerable quickness, though they move awkwardly, and much less securely than man.' This is a little misleading, inasmuch as it is not stated that this upright progression is effected by placing the enormously long arms behind the head or holding them out backwards as a balance in progression.

We have already seen that $\mathrm{Mr}$. Darwin tries to account for man's hairlessness by the help of 'sexual selection.' He also, however, speculates as to the possibility of his having lost it through heat of climate, saying:- Elephants and rhinoceroses are almost hairless; and as certain extinct species which formerly lived under an arctic climate were covered with long wool or hair, it would almost appear as if the existing species of both genera have lost their hairy covering from exposure to heat' (vol. i. p. 148). 
This affords us a good example of hasty and inconclusive speculation. Surely it would be as rational to suppose that the arctic species had gained their coats as that the tropical species had lost theirs. But over-hasty conclusions are, we regret to say, the rule in Mr. Darwin's speculations as to man's genealogy. He carries that genealogy back to some ancient form of animal life somewhat like an existing larval Ascidian; and he does this on the strength of the observations of Kowalevsky and Kuppfer. He assumes at once that the similarities of structure which those observers detected are due to descent instead of to independent similarity of evolution, though the latter mode of origin is at least possible, ${ }^{1}$ and can hardly be considered improbable when we reflect on the close similarity independently induced in the eyes of fishes and cephalopods.

Quite recently, however, observations have been published by Dr. Donitz, ${ }^{2}$ which render it necessary, at the least, to pause and reconsider the question before admitting the Ascidian ancestry of the Vertebrate sub-kingdom.

We now come to the consideration of a subject of great importance-namely, that of man's mental powers. Are they, as Mr. Darwin again and again affirms that they are, ${ }^{3}$ different only in degree and not in kind from the mental powers of brutes? As is so often the case in discussions, the error to be combated is an implied negation. Mr. Darwin implies and seems to assume, that when two things have certain characters in common, there can be no fundamental difference between them.

1 See Professor Rolleston's Address at the Liverpool Meeting of the British Association, 1870.

2 See Journal für Anatomie und Plysiologie, edited by Reichert and Dubois, Berlin.

3 'There is no fundamental difference between man and the higher mammals in their mental faculties.'-Descent of Man, vol. i. p. 35. 
To avoid ambiguity and obscurity, it may be well here to state plainly certain very elementary matters. The ordinary antecedents and concomitants of distinctly felt sensations may exist, with all their physical consequences, in the total absence of intellectual cognisance, as is shown by the wellknown fact, that when through fracture of the spine the lower limbs of a man are utterly deprived of the power of feeling, the foot may nevertheless withdraw itself from tickling just as if a sensation was consciously felt. Amongst lower animals, a decapitated frog will join its hind feet together to push away an irritating object just as an uninjured animal will do. Here we have coadjusted actions resulting from stimuli which normally produce sensation, but occurring under conditions in which cerebral action does not take place. Did it take place, we should have sensations, but by no means necessarily intellectual action.

'Sensation' is not 'thought,' and no amount of the former would constitute the most rudimentary condition of the latter, though sensations supply the conditions for the existence of 'thought' or ' knowledge.'

Altogether, we may clearly distinguish at least six kinds of action to which the nervous system ministers :-

I. That in which impressions received, result in appropriate movements without the intervention of sensation or thought, as in the cases of injury above given.-This is the reflex action of the nervous system.

II. That in which stimuli from without, result in sensations through the agency of which their due effects are wrought out.-Sensation.

III. That in which impressions received, result in sensations, which give rise to the observation of sensible objects. - Sensible perception.

IV. That in which sensations and perceptions continue to coalesce, agglutinate, and combine in more or less complex 
aggregations, according to the laws of the association of sensible perceptions.-Association.

The above four groups contain only indeliberate operations, consisting, as they do at the best, but of mere presentative sensible ideas in no way implying any reflective or representative faculty. Such actions minister to and form Instinct. Besides these, we may distinguish two other kinds of mental action, namely:-

V. That in which sensations and sensible perceptions are reflected on by thought, and recognised as our own, and we ourselves recognised by ourselves as affected and perceiving. -Self-consciousness.

VI. That in which we reflect upon our sensations or perceptions, and ask what they are and why they are.-Reason.

These two latter kinds of action are deliberate operations, performed as they are by means of representative ideas implying the use of a reflective representative faculty. Such actions distinguish the intellect or rational faculty. Now, we assert that the full possession of all the first four (presentative) kinds of action, by no means implies the possession of the last two (representative) kinds also. All persons, we think, must admit the truth of the following propositions :-

Two faculties are distinct, not in degree but in kind, if we may possess the one in perfection without that fact implying that we possess the other also. Still more will this be the case if the two faculties tend to increase in an inverse ratio. Yet this is the distinction between the instinctive and the intellectual parts of man's nature.

As to animals, we fully admit that they may possess all the first four groups of actions-that they may have, so to speak, mental inages of sensible objects combined in all degrees of complexity, as governed by the laws of association. We deny to them, on the other hand, the possession of the last two kinds of mental action. We deny to them, that is, 
the power of reflecting on their own existence, or of inquiring into the nature of objects and their causes. We deny that they know that they know or know themselves in knowing. In other words, we deny them reason. The possession of the presentative faculty, as above explained, in no way implies that of the reflective faculty; nor does any amount of direct operation imply the power of asking the reflective question before mentioned, as to 'what' and 'why.'

According to our above given definition, then, the faculties of men and those of other animals differ in kind; and brutes low in the scale supply us with a good example in support of this distinctness ; for it is in those animals which are generally admitted to be wanting in reason-such as insects (e.g. the ant and the bee)-that we have the very summit and perfection of instinct made known to us.

We will shortly examine Mr. Darwin's arguments, and see if he can bring forward a single instance of brute action implying the existence in it of the representative reflective power. Before doing so, however, one or two points as to the conditions of the controversy must be noticed.

In the first place, the position which we maintain is the one in possession-that which is commended to us by our intuitions, by ethical considerations, and by religious teaching universally. The onus probandi should surely therefore rest with him who, attacking the accepted position, maintains the essential similarity and fundamental identity of powers, the effects of which are so glaringly diverse. Yet Mr. Darwin quietly assumes the whole point in dispute, by asserting identity of intuition where there is identity of sensation (vol. i. p. 36), which, of course, implies that there is no mental power whatever except sensation. For if the existence of another faculty were allowed by him, it is plain that the action of that other faculty might modify the effects of mere sensation in any being possessed of such additional faculty. 
Secondly, it must be remembered that it is a law in all reasoning that where known causes are sufficient to account for any phenomena we shall not gratuitously call in additional causes. If, as we believe to be the case, there is no need whatever to call in the representative faculty as an explanation of brute mental action;-if the phenomena brutes exhibit can be accounted for by the presentative faculty-that is, by the presence of sensible perceptions and emotions, together with the reflex and co-ordinating powers of the nervous system; - then to ascribe to them the possession of reason is thoroughly gratuitous.

Thirdly, in addition to the argument that brutes have not intellect because their actions can be accounted for without the exercise of that faculty, we have other and positive arguments in opposition to Mr. Darwin's view of their mental powers. These arguments are based upon the absence in brutes of articulate and rational speech, of true concerted action and of educability, in the human sense of the word. We have besides, what may be called an experimental proof in the same direction. For if the germs of a rational nature existed in brutes, such germs would certainly ere this have so developed as to have produced unmistakably rational phenomena, considering the prodigious lapse of time passed since the entombment of the earliest known fossils. To this question we will return later.

We shall perhaps be met by the assertion that many men may also be taken to be irrational animals, so little do the phenomena they exhibit exceed in dignity and importance the phenomena presented by certain brutes. But, in reply, it is to be remarked that we can only consider men who are truly men-not idiots, and that all men, however degraded their social condition, have self-consciousness properly so called, possess the gift of articulate and rational speech, are capable of true concerted action, and have a perception of 
the existence of right and wrong. On the other hand, no brute has the faculty of articulate, rational speech: most persons will also admit that brutes are not capable of truly concerted action, and we contend most confidently that they have no self-consciousness, properly so called, and no perception of the difference between truth and falsehood and right and wrong.

Let us now consider Mr. Darwin's facts in favour of an opposite conclusion.

First, his testimony drawn from his own experience and information regarding the lowest races of men.

Secondly, the anecdotes he narrates in favour of the intelligence of brutes.

In the first place, we have to thank our author for very distinct and unqualified statements as to the substantial unity of men's mental powers. Thus he tells us :-

'The Fuegians rank amongst the lowest barbarians; but I was continually struck with surprise how closely the three natives on board H.M.S. "Beagle," who had lived some years in England, and could talk a little English, resembled us in disposition, and in most of our mental qualities.'-Vol. i. p. 34 .

Again he adds :-

'The American aborigines, Negroes, and Europeans differ as much from each other in mind as any three races that can be named; yet I was incessantly struck, whilst living with the Fuegians on board the " Beagle," with the many little traits of character, showing how similar their minds were to ours; and so it was with a full-blooded negro with whom I happened once to be intimate.'-Vol. i. p. 232.

Again:- 'Differences of this kind (mental) between the highest men of the highest races and the lowest savages are connected by the finest gradations' (vol. i. p. 35).

Mr. Darwin, then, plainly tells us that all the essential mental characters of civilised man are found in the very lowest races of men, though in a less completely developed state; while, in comparing their mental powers with those of VOL. II. 
brutes, he says, 'No doubt the difference in this respect is enormous' (vol. i. p. 34). As if, however, to diminish the force of this admission, he remarks, what no one would dream of disputing, that there are psychical phenomena common to men and to other animals. He says of man that

' He uses in common with the lower animals inarticulate cries to express his meaning, aided by gestures and the movements of the muscles of the face. This especially holds good with the more simple and vivid feelings, which are but little connected with the higher intelligence. Our cries of pain, fear, surprise, anger, together with their appropriate actions, and the murmur of a mother to her beloved child, are more expressive than any words.' - Vol. i. p. 54.

But, inasmuch as it is admitted on all hands that man is an animal, and therefore has all the four lower faculties enumerated in our list, as well as the two higher ones, the fact that he makes use of common instinctive actions in no way diminishes the force of the distinction between him and brutes, as regards the representative, reflective faculties. It rather follows as a matter of course from his animality that he should manifest phenomena common to him and to brutes. That man has a common nature with them is perfectly compatible with his having, besides, a superior nature and faculties of which no brute has any rudiment or vestige. Indeed, all the arguments and objections in Mr. Darwin's second chapter may be met by the fact that man being an animal, has corresponding faculties, whence arises a certain external conformity with other animals as to the modes of expressing some mental modifications. In the overlooking of this possibility of coexistence of two natures, lies that error of negation to which we before alluded. Here, as in other parts of the book, we may say there are two quantities $a$ and $a+x$, and Mr. Darwin, seeing the two as but neglecting the $x$, represents the quantities as equal.

We will now notice the anecdotes narrated by Mr. Darwin 
in support of the rationality of brutes. Before doing so, however, we must remark that our author's statements, given on the authority (sometimes second-hand authority) of others, afford little evidence of careful criticism. This is the more noteworthy when we consider the conscientious care and pains which he bestows on all the phenomena which he examines himself.

Thus, for example, we are told on the authority of Brehm that-

'An eagle seized a young cercopithecus, which, by clinging to a branch, was not at once carried off ; it cried loudly for assistance, upon which other members of the troop, with much uproar, rushed to the rescue, surrounded the eagle, and pulled out so many feathers that he no longer thought of his prey, but only how to escape.'-Vol. i. p. 76 .

We confess we wish that Mr. Darwin had himself witnessed this episode. Perhaps, however, he has seen other facts sufficiently similar to render this one credible. In the absence of really trustworthy evidence we should, however, be inclined to doubt the fact of a young cercopithecus, unexpectedly seized, being able, by clinging, to resist the action of an eagle's wings.

We are surprised that Mr. Darwin should have accepted the following tale without suspicion:-

'One female baboon had so capacious a heart that she not only adopted young monkeys of other species, but stole young dogs and cats which she continually carried about. Her kindness, however, did not go so far as to share her food with her adopted offspring, at which Brehm was surprised, as his monkeys always divided everything quite fairly with their own young ones. An adopted kitten scratched the above-mentioned affectionate baboon, who certainly had a fine intellect, for she was much astonished at being scratched, and immediately examined the kitten's feet, and without more ado bit off the claws' (!!!). -Vol. i. p. 41.

Has Mr. Darwin ever tested this alleged fact? Would it 
be possible for a baboon to bite off the claws of a kitten without keeping the feet perfectly straight?

Again, we have an anecdote on only second-hand authority (namely a quotation by Brehm of Schimper) to the following effect :-

'In Abyssinia, when the baboons belonging to one species ( $C$. gelada) descend in troops from the mountains to plunder the fields, they sometimes encounter troops of another species (C. hamadryas), and then a fight ensues. The Geladas roll down great stones, which the Hamadryas try to avoid, and then both species, making a great uproar, rush furiously against each other. Brehm, when accompanying the Duke of Coburg-Gotha, aided in an attack with firearms on a troop of baboons in the Pass of Mensa in Abyssinia. The baboons in return rolled so many stones down the mountain, some as large as a man's head, that the attackers had to beat a hasty retreat; and the pass was actually for a time closed against the caravan. It deserves notice that these baboons thus acted in concert.'-Vol. i. p. 51 .

Now, if every statement of fact here given be absolutely correct, it in no way even tends to invalidate the distinction we have drawn between 'instinct' and 'reason'; but the positive assertion that the brutes 'acted in concert,' when the evidence proves nothing more than that their actions were simultaneous, shows a strong bias on the part of the narrator. A flock of sheep will simultaneously turn round and stare and stamp at an intruder; but this is not 'concerted action?' which means that actions are not only simultaneous, but are so in consequence of a reciprocal understanding and convention between the various agents. It may be added that if any brutes were capable of such really concerted action, the effects would soon make themselves known to us so forcibly as to prevent the possibility of mistake.

We come now to Mr. Darwin's instances of brute rationality. In the first place he tells us :-

' $\mathrm{I}$ had a dog who was savage and averse to all strangers, and I purposely tried his memory after an absence of five years and two 
days. I went near the stable where he lived, and shouted to him in my old manner; he showed no joy, but instantly followed me out walking and obeyed me, exactly as if I had parted with him only half an hour before. A train of old associations, dormant during five years, had thus been instantaneously awakened in his mind.'-Vol i. p. 45.

No doubt! but this is not 'reason.' Indeed, we could hardly have a better instance of the mere action of associated sensible impressions. What is there here which implies more than memory, impressions of sensible objects and their association? Had there been reason there would have been signs of joy and wonder, though such signs would not alone prove reason to exist. It is evident that Mr. Darwin's own mode of explanation is the sufficient one-namely, by a train of associated sensible impressions. Mr. Darwin surely cannot think that there is in this case any evidence of the dog's having put to himself those questions which, under the circumstances, a rational being would put. Mr. Darwin also tells us how a monkey-trainer gave up in despair the education of monkeys of which the attention was easily distracted from his teaching, while 'a monkey which carefully attended to him could always be trained.' But 'attention' does not imply 'reason.' The anecdote only shows that some monkeys are more easily impressed and more retentive of impressions than others.

Again, we are told, as an instance of reason, that ' Rengger sometimes put a live wasp in paper so that the monkeys in hastily unfolding it got stung; after this had once happened, they always first held the packet to their ears to detect any movement within.' But here again we have no need to call in the aid of 'reason.' The monkeys had had the group of sensations 'folded paper' associated with the other groups'noise and movement' and 'stung fingers.' The second time they experience the group of sensations 'folded paper' the 
succeeding sensations (in this instance only too keenly associated) are forcibly recalled, and with the recollection of the sensation of hearing, the hand goes to the ear. Yet Mr. Darwin considers this unimportant instance of such significance that he goes on to say:-

'Any one who is not convinced by such facts as these, and by what he may observe with his own dogs, that animals can reason, would not be convinced by anything I could add. Nevertheless, I will give one case with respect to dogs, as it rests on two distinct observers, and can hardly depend on the modification of any instinct. Mr. Colquhoun winged two wild ducks, which fell on the opposite side of a stream; his retriever tried to bring over both at once, but could not succeed; she then, though never before known to ruffle a feather, deliberately killed one, brought over the other, and returned for the dead bird. Colonel Hutchinson relates that two partridges were shot at once, one being killed and the other wounded; the latter ran away, and was caught by the retriever, who on her return came across the dead bird; she stopped, evidently greatly puzzled, and after one or two trials, finding she could not take it up without permitting the escape of the winged bird, she considered a moment, then deliberately murdered it by giving it a severe crunch, and afterwards brought away both together. This was the only known instance of her having wilfully injured any game.'

Mr. Darwin adds :-

'Here we have reason, though not quite perfect, for the retriever might have brought the wounded bird first and then returned for' the dead one, as in the case of the two wild ducks.'-Vol. i. pp. $47,48$.

Here, we reply, we have nothing of the kind, and to bring 'reason' into play is gratuitous. The circumstances can be perfectly explained (and on Mr. Darwin's own principles) as evidences of the revival of an old instinct. The ancestors of sporting dogs of course killed their prey, and that trained dogs do not kill it is simply due to man's action, which has suppressed the instinct by education, and which continually thus keeps it under control. It is indubitable that the old tendency must be latent, and that a small interruption in the 
normal retrieving process, such as occurred in the cases cited, would probably be sufficient to revive that old tendency and call the obsolete habit into exercise.

But perhaps the most surprising instance of groundless inference is presented in the following passage :-

' My dog, a full-grown and very sensible animal, was lying on the lawn during a hot and still day; but at a little distance a slight breeze occasionally moved an open parasol, which would have been wholly disregarded by the dog had any one stood near it. As it was, every time that the parasol slightly moved, the dog growled fiercely and barked. He must, I think, have reasoned to himself in a rapid and unconscious manner, that movement without any apparent cause indicated the presence of some strange living agent, and no stranger had a right to be on his territory.'-Vol. i. p. 67.

The consequences deduced from this trivial incident are amazing. Probably, however, Mr. Darwin does not mean what he says; but, on the face of it, we have a brute credited with the abstract ideas 'movement,' 'causation,' and the notions logically arranged and classified in subordinate genera - 'agent,' 'living agent,' 'strange living agent.' He also attributes to it the notion of 'a right' of 'territorial limitation,' and the relation of such 'limited territory' and 'personal ownership.' It may safely be affirmed that if a dog could so reason in one instance he would in others, and would give much more unequivocal proofs for Mr. Darwin to bring forward.

Mr. Darwin, however, speaks of reasoning in an 'unconscious manner,' so that he cannot really mean any process of reasoning at all; but, if so, his case is in no way apposite. Even an insect can be startled, and will exhibit as much evidence of rationality as is afforded by the growl of a dog; and all that is really necessary to explain such a phenomenon exists in an oyster, or even in the much talked-of Ascidian.

Thus, then, it appears that, even in Mr. Darwin's 
specially-selected instances, there is not a tittle of evidence tending, however slightly, to show that any brute possesses the representative reflective faculties. But if, as we assert, brute animals are destitute of such higher faculties, it may well be that those lower faculties which they have (and which we more or less share with them) are highly developed, and their senses possess a degree of keenness and quickness inconceivable to us. Their minds ${ }^{1}$ being entirely occupied with such lower faculties, and having, so to speak, nothing else to occupy them, their sensible impressions may become interwoven and connected to a far greater extent than in us. Indeed, in the absence of free will, the laws of this association of ideas obtain supreme command over the minds of brutes: the brute being entirely immersed, as it were, in his presentative faculties.

There yet remain two matters for consideration, which tend to prove the fundamental difference which exists between the mental powers of man and brutes:-1. The mental equality between animals of very different grades of structure, and their non-progressiveness; 2. The question of articulate speech.

Considering the vast antiquity of the great animal groups, ${ }^{2}$ it is, indeed, remarkable how little advance in mental capacity has been achieved even by the highest brutes. This is made especially evident by Mr. Darwin's own assertions as to the capacities of lowly animals. Thus he tells us that:-

'Mr. Gardner, whilst watching a shore-crab (Gelasimus) making its burrow, threw some shells towards the hole. One rolled in, and

1 The words ' mind,' 'mental,' 'intelligence,' etc., are here made use of in reference to the psychical faculties of brutes, in conformity to popular usage, and not as strictly appropriate.

${ }^{2}$ Mr. Darwin (vol. i. p. 360) refers to Dr. Scudder's discovery of 'a fossil insect in the Devonian formation of New Brunswick, furnished with the well-known tympanum or stridulating apparatus of the male Locustidæ.' 


\section{The Descent of Man}

three other shells remained within a few inches of the mouth. In about five minutes the crab brought out the shell which had fallen in, and carried it away to the distance of a foot; it then saw the three other shells lying near, and evidently thinking that they might likewise roll in, carried them to the spot where it had laid the first.' -Vol. i. p. 334.

Mr. Darwin adds or quotes the astonishing remark, 'It would, I think, be difficult to distinguish this act from one performed by man by the aid of reason. Again, he tells us :-

'Mr. Lonsdale informs me that he placed a pair of land-shells (IIelix pomatia), one of which was weakly, into a small and ill-provided garden. After a short time the strong and healthy individual disappeared, and was traced by its track of slime over a wall into an adjoining well-stocked garden. Mr. Lonsdale concluded that it had dleserted its sickly mate; but after an absence of twenty-four hours it returned, and apparently communicated the result of its successful exploration, for both then started along the same track and disappeared over the wall.'-Vol. i. p. 325.

Whatever may be the real value of the statements quoted, they harmonise with a matter which is incontestable. We refer to the fact that the intelligence of brutes, be they high or be they low, is essentially one in kind, there being a singular parity between animals belonging to groups widely different in type of structure and in degree of development.

Apart from the small modifications which experience occasionally introduces into the habits of animals - as sometimes occurs after man has begun to frequent a newly-discovered island-it cannot be denied that, looking broadly over the whole animal kingdom, there is no evidence of advance in mental power on the part of brutes. This absence of progression in animal intelligence is a very important consideration, and it is one which does not seem to be adverted to by Mr. Darwin, though the facts detailed by him are exceedingly suggestive of it.

When we speak of this absence of progression we do not, 
of course, mean to deny that the dog is superior in mental activity to the fish, or the jackdaw to the toad. But we mean that, considering the vast period of time that must (on Mr. Darwin's theory) have elapsed for the evolution of an Orang from an Ascidian, and considering how beneficial increased intelligence must be to all in the struggle for life, it is inconceivable (on Mr. Darwin's principles only) that a mental advance should not have taken place greater in degree, more generally diffused, and more in proportion to the grade of the various animals than we find to be actually the case. For in what respect is the intelligence of the ape superior to that of the dog or of the elephant? It cannot be said that there is one point in which its psychical nature approximates to man more than that of those four-footed beasts. But, again, where is the great superiority of a dog or an ape over a bird? The falcon trained to hawking is at least as remarkable an instance of the power of education as the trained dog. The tricks which birds can be taught to perform are as complex and wonderful as those acted by the mammal. The phenomena of nidification, and some of those now brought forward by Mr. Darwin as to courtship, are fully comparable with analogous phenomena of quasi-intelligence in any beast.

This, however, is but a small part of the argument. For let us descend to the invertebrata, and what do we find? - it restriction of their quasi-mental faculties proportioned to their constantly inferior type of structure? By no means. We find, e.g. in ants, phenomena which simulate those of an intelligence such as ours far more than do any phenomena exhibited by the highest beasts. Ants display a complete and complex political organisation, classes of beings socially distinct, war resulting in the capture of slaves, and the appropriation and maintenance of domestic animals (Aphides) analogous to our milk-giving cattle. 


\section{The Descent of Man}

Mr. Darwin truthfully remarks on the great difference in these respects between such creatures as ants and bees, and singularly inert members of the same class - such as the scale insect or coccus. But can it be pretended that the action of natural and sexual selection has alone produced these phenomena in certain insects, and failed to produce thern in any other mere animals even of the very highest class? If these phenomena are due to a power and faculty similar in kind to human intelligence, and which power is latent and capable of evolution in all animals, then it is certain that this power must have been evolved in other instances also, and that we should see varying degrees of it in many, and notably in the highest brutes as well as in man. If, on the other hand, the faculties of brutes are different in kind from human intelligence, there can be no reason whatever why animals most closely approaching man in physical structure should resemble him in psychical nature also.

This reflection leads us to the difference which exists between men and brutes as regards the faculty of articulate speech. Mr. Darwin remarks that of the distinctively human characters this has 'justly been considered as one of the chief' (vol. i. p. 53). We cannot agree in this. Some brutes can articulate, and it is quite conceivable that brutes might (though as a fact they do not) so associate certain sensations and gratifications with certain articulate sounds as, in a certain sense, to speak. This, however, would in no way even tend to bridge over the gulf which exists between the representative reflective faculties and the merely presentative ones. Articulate signs of sensible impressions would be fundamentally as distinct as mere gestures are from truly rational speech.

Mr. Darwin evades the question about language by in one place (vol. i. p. 54) attributing that faculty in man to his 
having acquired a higher intellectual nature; and in another (vol. ii. p. 391), by ascribing his higher intellectual nature to his having acquired that faculty.

Our author's attempts to bridge over the chasm which separates instinctive cries from rational speech are remarkable examples of groundless speculation. Thus he ventures to say

' that primeval man, or rather some early progenitor of man, probably used his voice largely, as does one of the gibbon-apes at the present day, in producing true musical cadences, that is, in singing; we may conclude from a widely-spread analogy that this power would have been especially exerted during the courtship of the sexes, serving to express various emotions, as love, jealousy, triumph, and serving as a challenge to their rivals. The imitation by articulate sounds of musical cries might have given rise to words expressive of various complex emotions.'

\section{And again :-}

'It does not appear altogether incredible, that some unusually wise ape-like animal should have thought of imitating the growl of a beast of prey, so as to indicate to his fellow-monkeys the nature of the expected danger. And this would have been a first step in the formation of a language.'-Vol. i. p. 56 .

But the question is, not whether it is incredible, but whether there are any data whatever to warrant such a supposition. Mr. Darwin brings forward none: we suspect none could be brought forward.

It is not, however, emotional expressions or manifestations of sensible impressions, in whatever way exhibited, which have to be accounted for, but the enunciation of distinct deliberate judgment as to 'the what,' 'the how,' and 'the why,' by definite articulate sounds; and for these Mr. Darwin not only does not account, but he does not adduce anything even tending to account for them. Altogether we may fairly conclude, from the complete failure of $\mathrm{Mr}$. Darwin to establish 
identity of kind between the mental faculties of man and of brutes, that identity cannot be established; as we are not likely for many years to meet with a naturalist so competent to collect and marshal facts in support of such identity, if any such facts there are. The old barrier, then, between 'presentative instinct' and 'representative reason' remains still unimpaired, and, as we believe, insurmountable.

We now pass to another question, which is of even greater consequence than that of man's intellectual powers. Mr. Darwin does not hesitate to declare that even the 'moral sense' is a mere result of the development of brutal instincts. He maintains, 'the first foundation or origin of the moral sense lies in the social instincts, including sympathy; and these instincts no doubt were primarily gained, as in the case of the lower animals, through natural selection' (vol. ii. p. 394).

Everything, however, depends upon what we mean by the 'moral sense.' It is a patent fact that there does exist a perception of the qualities 'right' and 'wrong' attaching to certain actions. However arising, men have a consciousness of an absolute and immutable rule legitimately claiming obedience with an authority necessarily supreme and absolute - in other words, intellectual judgments are formed which imply the existence of an ethical ideal in the judging mind.

It is the existence of this power which has to be accounted for; neither its application nor even its validity have to be considered. Yet instances of difference of opinion respecting the moral value of particular concrete actions are often brought forward as if they could disprove the existence of moral intuition. Such instances are utterly beside the question. It is amply sufficient for our purpose if it be conceded that developed reason dictates to us that certain modes of 
action, abstractedly considered, are intrinsically wrong; and this we believe to be indisputable.

It is equally beside the question to show that the existence of mutually beneficial acts and of altruistic habits can be explained by 'natural selection.' No amount of benevolent habits tend even in the remotest degree to account for the intellectual perception of 'right' and 'duty.' Such habits may make the doing of beneficial acts pleasant, and their omission painful; but such feelings have essentially nothing whatever to do with the perception of 'right' and 'wrong,' nor will the faintest incipient stage of the perception be accounted for by the strongest development of such sympathetic feelings. Liking to do acts which happen to be good is one thing; seeing that actions are good, whether we or others like them or not, is quite another.

Mr. Darwin's account of the moral sense is very different from the above. It may be expressed most briefly by saying that it is the prevalence of more enduring instincts over less persistent ones-the former being social instincts, the latter personal ones. He tells us :-

'As man cannot prevent old impressions continually re-passing through his mind, he will be compelled to compare the weaker impressions of, for instance, past hunger, or of vengeance satisfied, or danger avoided at the cost of other men, with the instinct of sympathy and goodwill to his fellows, which is still present and ever in some degree active in his mind. He will then feel in his imagination that a stronger instinct has yielded to one which now seems comparatively weak; and then that sense of dissatisfaction will inevitably be felt with which man is endowed, like every other animal, in order that his instincts may be obeyed.'-Vol. i. p. 90 .

Mr. Darwin means by 'the moral sense' an instinct, and adds, truly enough, that 'the very essence of an instinct is, that it is followed independently of reason' (vol. i. p. 100). But the very essence of moral action is that it is not followed independently of reason. 
Having stated our wide divergence from Mr. Darwin with respect to what the term 'moral sense' denotes, we might be dispensed from criticising instances which must from our point of view be irrelevant, as Mr. Darwin would probably admit. Nevertheless, let us examine a few of these instances, and see if we can discover in them any justification of the views he propounds.

As illustrations of the development of self-reproach for the neglect of some good action, he observes :-

'A young pointer, when it first scents game, apparently cannot help pointing. A squirrel in a cage who pats the nuts which it cannot eat, as if to bury them in the ground, can hardly be thought to act thus either from pleasure or pain. Hence the common assumption that men must be impelled to every action by experiencing some pleasure or pain may be erroneous. Although a habit may be blindly and implicitly followed, independently of any pleasure or pain felt at the moment, yet if it be forcibly and abruptly checked, a vague sense of dissatisfaction is generally experienced; and this is especially true in regard to persons of feeble intellect.'-Vol. i. p. 80 .

Now, passing over the question whether in the 'pointing' and 'patting' referred to there may not be some agreeable sensations, we contend that such instincts have nothing to do with 'morality,' from their blind nature, such blindness simply ipso facto eliminating every vestige of morality from an action.

Mr. Darwin certainly exaggerates the force and extent of social sympathetic feelings. Mr. Mill admits that they are 'often wanting'; but Mr. Darwin claims the conscious possession of such feelings for all, and quotes Hume as saying that the view of the happiness of others ' communicates a secret joy,' while the appearance of their misery 'throws a melancholy damp over the imagination.' ${ }^{1}$ One might wish that this remark were universally true, but unfortunately

${ }^{1}$ Enquiry Concerning the Principles of Morals, edit. 1751, p. 132. 
some men take pleasure in the pain of others ; and La Rochefoucauld even ventured on the now well-known saying, 'that there is something in the misfortunes of our best friends not unpleasant to us.' But our feeling that the sufferings of others are pleasant or unpleasant has nothing to do with the question, which refers to the judgment whether the indulging of such feelings is 'right' or ' wrong.'

If the 'social instinct' were the real basis of the moral sense, the fact that society approved of anything would be recognised as the supreme sanction of it. Not only, however, is this not so, not only do we judge as to whether society in certain cases is right or wrong, but we demand a reason why we should obey society at all; we demand a rational basis and justification for social claims, if we happen to have a somewhat inquiring turn of mind. We shall be sure avowedly or secretly to despise and neglect the performance of acts which we do not happen to desire, and which have not an intellectual sanction.

The only passage in which our author seems as if about to meet the real question at issue is very disappointing, as the difficulty is merely evaded. He remarks, ' I am aware that some persons maintain that actions performed impulsively do not come under the dominion of the moral sense, and cannot be called moral' (vol. i. p. 87). This is not a correct statement of the intuitive view, and the difficulty is evaded thus: 'But it appears scarcely possible to draw any clear line of distinction of this kind, though the distinction may be real!' It seems to us, however, that there is no difficulty at all in drawing a line between a judgment as to an action being right or wrong and every other kind of mental act. Mr. Darwin goes on to say:-

'Moreover, an action repeatedly performed by us will at last be done without deliberation or hesitation, and can then hardly be distinguished from an instinct; yet surely no one will pretend that an 
action thus done ceases to be moral. On the contrary, we all feel that an act cannot be considered as perfect, or as performed in the most noble manner, unless it is done impulsively, without deliberation or effort, in the same manner as by a man in whom the requisite qualities are innate.'-Vol. i. p. 88.

To this must be replied, in one sense, 'Yes'; in another, 'No.' An action which has ceased to be directly or indirectly deliberate, has ceased to be moral as a distinct act, but it is moral as the continuation of those preceding deliberate acts ${ }^{1}$ through which the good habit was originally formed, and the rapidity with which the will is directed in the case supposed may indicate the number and constancy of antecedent meritorious volitions. Mr. Darwin seems to see this more or less, as he adds: 'He who is forced to overcome his fear or want of sympathy before he acts, deserves, however, in one way higher credit than the man whose innate disposition leads him to do a good act without effort.'

As an illustration of the genesis of remorse, we have the case

' of a temporary though for the time strongly persistent instinct conquering another instinct which is usually dominant over all others.' Swallows 'at the proper season seem all day long to be impressed with the desire to migrate; their habits change; they become restless, are noisy, and congregate in flocks. Whilst the mother-bird is feeding or brooding over her nestlings, the maternal instinct is probably stronger than the migratory; but the instinct which is more persistent gains the victory, and at last, at a moment when her young ones are not in sight, she takes flight and deserts them. When arrived at the end of her long journey, and the migratory instinct ceases to act, what an agony of remorse each bird would feel, if, from being endowed with great mental activity, she could not prevent the image continually passing before her mind of her young ones perishing in the bleak north from cold and hunger.'-Vol. i. p. 90.

Let us suppose she does suffer 'agony,' that feeling would be nothing to the purpose. What is requisite is that she ${ }^{1}$ See ante, vol. i. p. 329.

VOL. II. 
should judge that she ought not to have left them. To make clear our point, let us imagine a man formerly entangled in ties of affection which in justice to another his conscience has induced him to sever. The image of the distress his act of severance has caused may occasion him keen emotional suffering for years, accompanied by a clear perception that his act has been right. Again, let us suppose another case: The struggling father of a family becomes aware that the property on which he lives really belongs to another, and he relinquishes it. He may continue to judge that he has done a proper action, whilst tortured by the trials in which his act of justice has involved him. To assert that these acts are merely instinctive would be absurdly false. In the cases supposed, obedience is paid to a clear intellectual perception against the very strongest instincts.

That we have not misrepresented Mr. Darwin's exposition of ' conscience' is manifest. He says that if a man has gratified a passing instinct, to the neglect of an enduring instinct, he ' will then feel dissatisfied with himself, and will resolve with more or less force to act differently for the future. This is conscience; for conscience looks backwards and judges past actions, inducing that kind of dissatisfaction, which if weak we call regret, and if severe remorse' (vol. i. p. 91). 'Conscience,' certainly, 'looks back and judges,' but not all that 'looks back and judges' is 'conscience.' A judgment of conscience is one of a particular kind, namely, a judgment according to the standard of moral worth. But for this, a gourmand, looking back and judging that a particular sauce had occasioned him dyspepsia, would, in the dissatisfaction arising from his having eaten the wrong dish at dinner, exercise his conscience!

Indeed, elsewhere (vol. i. p. 103), Mr. Darwin speaks of 'the standard of morality rising higher and higher,' though he nowhere explains what he means either by the 'standard 
or by the 'higher'; and, indeed, it is very difficult to understand what can possibly be meant by this 'rising of the standard,' if the 'standard' is from first to last pleasure and profit.

We find, again, the singular remark :- 'If any desire or instinct leading to an action opposed to the good of others still appears to a man, when recalled to mind, as strong as or stronger than his social instinct, he will feel no keen regret at having followed it' (vol. i. p. 92).

Mr. Darwin is continually mistaking a merely beneficial action for a moral one; but, as before said, it is one thing to act well and quite another to be a moral agent. A dog, or even a fruit-tree, may act well, but neither is a moral agent. Of course, all the instances he brings forward with regard to animals are not in point, on account of this misconception of the problem to be solved. He gives, however, some examples which tell strongly against his own view. Thus, he remarks of the Law of Honour-' The breach of this law, even when the breach is known to be strictly accordant with true morality, has caused many a man more agony than a real crime. We recognise the same influence in the sense of burning shame which most of us have felt, even after the interval of years, when calling to mind some accidental breach of a trifling, though fixed, rule of etiquette' (vol. i. p. 92). This is most true; some trifling breach of good manners may, indeed, occasion us pain; but this may be unaccompanied by a judgment that we are morally blameworthy. It is judgment, and not feeling, which has to do with right and wrong. But a yet better example might be given. What quality can have been more universally useful to social communities than courage? It has always been, and is still, greatly admired and highly appreciated, and is especially adapted, both directly and indirectly, to enable its possessors to become the fathers of succeeding generations. If the 
social instinct were the basis of the moral sense, it is infallibly certain ${ }^{1}$ that courage must have come to be regarded as supremely 'good,' and cowardice to be deserving of the deepest moral condemnation. And yet what is the fact? A coward feels probably self-contempt, and that he has incurred the contempt of his associates, but he does not feel 'wicked.' $\mathrm{He}$ is painfully conscious of his defective organisation, but he knows that an organisation, however defective, cannot, in itself, constitute moral demerit. Similarly, we, the observers, despise, avoid, or hate a coward; but we can clearly understand that a coward may be a more virtuous man than another who abounds in animal courage.

The better still to show how completely distinct are the conceptions 'enduring or strong instincts' and 'virtuous desires' on the one hand, and 'transient or weak impulses' and 'vicious inclinations' on the other, let us substitute in the following passage for the words which Mr. Darwin, on his own principles, illegitimately introduces others which accord with those principles, and we shall see how such substitution eliminates every element of morality from the passage :-

'Looking to future generations, there is no cause to feal' that the social instincts will grow weaker, and we may expect that enduring [virtuous] habits will grow stronger, becoming perhaps fixed by inheritance. In this case the struggle between our stronger [higher] and weaker [lower] impulses will be less severe, and the strong [virtue] will be triumphant' (vol. i. p. 104).

As to past generations, Mr. Darwin tells us (vol. i. p. 166) that at all times throughout the world, tribes have supplanted other tribes; and as social acts are an element in their success, sociality must have been intensified, and this because ' an increase in the number of well-endowed men will cer-

${ }^{1}$ As before observed. See ante, vol. i. p. 464. 
tainly give an immense advantage to one tribe over another.' No doubt! but this only explains an augmentation of mutually beneficial actions. It does not in the least even tend to explain how the moral judgment was first formed.

Having thus examined Mr. Darwin's theory of Sexual Selection, and his comparison of the mental powers of man (including their moral application) with those of the lower animals, we have a few remarks to make upon his mode of conducting his argument.

In the first place, we must repeat what we have already said as to his singular dogmatism, and, in the second place, we must complain of the way in which he positively affirms again and again the existence of the very things which have to be proved. Thus, to take for instance the theory of the descent of man from some inferior form, he says:- 'The grounds upon which this conclusion rests will never be shaken' (vol. ii. p. 385), and 'the possession of exalted mental powers is no insuperable objection to this conclusion' (vol. i. p. 107). Speaking of sympathy, he boldly remarks :- 'This instinct no doubt was originally acquired like all the other social instincts through natural selection' (vol. i. p. 164); and 'the fundamental social instincts were originally thus gained' (vol. i. p. 173).

Again, as to the stridulating organs of insects, he says:'No one who admits the agency of natural selection, will dispute that these musical instruments have been acquired through sexual selection.' Speaking of the peculiarities of humming-birds and pigeons, Mr. Darwin observes :- ' The sole difference between these cases is, that in one the result is due to man's selection, whilst in the other, as with hummingbirds, birds of paradise, etc., it is due to sexual selection,that is, to the selection by the fernales of the more beautiful males' (vol. ii. p. 78). Of birds, the males of which are brilliant, but the hens are only slightly so, he remarks:- 
'These cases are almost certainly due to characters primarily acquired by the male, having been transferred, in a greater or less degree, to the female' (vol. ii. p. 128). 'The colours of the males may safely be attributed to sexual selection' (vol. ii. p. 194). As to certain species of birds in which the males alone are black, we are told, there can hardly be a doubt, that blackness in these cases has been a sexually selected character' (vol. ii. p. 226). The following, again, is far too positive a statement:- 'Other characters proper to the males of the lower animals, such as bright colours, and various ornaments have been acquired by the more attractive males having been preferred by the female. There are, however, exceptional cases, in which the males, instead of having been selected, have been the selectors' (vol. ii. p. 371).

It is very rarely that $\mathrm{Mr}$. Darwin fails in courtesy to his opponents; and we were therefore surprised at the tone of the following passage (vol. ii. p. 386):-' He who is not content to look, like a savage, at the phenomena of nature as disconnected, cannot any longer believe that man is the work of a separate act of creation. He will be forced to admit the contrary.' What justifies Mr. Darwin in his assumption that to suppose the soul of man to have been specially created is to regard the phenomena of nature as disconnected?

As an instance of Mr. Darwin's practice of begging the question at issue, we may quote the following assertion:- Any animal whatever, endowed with well-marked social instincts, would inevitably acquire a moral sense or conscience, as soon as its intellectual powers had become as well developed, or nearly as well developed, as in man ' (vol. i. p. 71). This is either a monstrous assumption or a mere truism; it is a truism, for, of course, any creature with the intellect of a man would perceive the qualities men's intellect is capable of perceiving, and, amongst them-moral worth. 


\section{The Descent of Man.}

Mr. Darwin, in a passage before quoted (vol. i. p. 86), slips in the whole of absolute morality, by employing the phrase 'appreciation of justice.' Again (vol. i. p. 168), when he speaks of aiding the needy, he remarks :- 'Nor could we check our sympathy, if so urged by hard reason, without deterioration in the noblest part of our nature.' How noblest? According to Mr. Darwin, a virtuous instinct is a strong and permanent one. There can be, according to his views, no other elements of quality than intensity and duration. Mr. Darwin, in fact, thus silently and unconsciously introduces the moral element into his 'social instinct,' and then, of course, has no difficulty in finding in the latter what he had previously put there. This, however, is quite illegitimate, as he makes the social instinct synonymous with the gregariousness of brutes. In such gregariousness, however, there is no moral element, because the mental powers of brutes are not equal to forming reflective, deliberate, representative judgments.

The word 'social' is ambiguous, as gregarious animals may metaphorically be called social, and man's social relations may be regarded both beneficentially and morally. Having first used 'social' in the former sense, it is subsequently applied in the latter; and it is thus that the really moral conception is silently and illegitimately introduced.

We may now sum up our judgment of Mr. Darwin's work on the Descent of Man - of its execution and tendency, of what it fails to accomplish and of what it has successfully attained.

Although the style of the work is, as we have said, fascinating, nevertheless we think that the author is somewhat encumbered with the multitude of his facts, which at times he seems hardly able to group and handle so effectively as might be expected from his special talent. Nor does he 
appear to have maturely reflected over the data he has so industriously collected. Moreover, we are surprised to find so accurate an observer receiving as facts many statements of a very questionable nature, as we have already pointed out, and frequently on second-hand authority. The reasoning also is inconclusive, the author having allowed himself constantly to be carried away by the warmth and fertility of his imagination. In fact, Mr. Darwin's power of reasoning seems to be in an inverse ratio to his power of observation. He now strangely exaggerates the action of 'sexual selection,' as previously he exaggerated the effects of the 'survival of the fittest.' On the whole, we are convinced that by the present work the cause of 'natural selection' has been rather injured than promoted; and we confess to a feeling of surprise that the case put before us is not stronger, since we had anticipated the production of far more telling and significant details from Mr. Darwin's biological treasure-house.

A great part of the work may be dismissed as beside the point-as a mere elaborate and profuse statement of the obvious fact, which no one denies, that man is an animal, and has all the essential properties of a highly organised one. Along with this truth, however, we find the assumption that he is no more than an animal-an assumption which is necessarily implied in Mr. Darwin's distinct assertion that there is no difference of kind, but merely one of degree, between man's mental faculties and those of brutes.

We have endeavoured to show that this is distinctly untrue. We maintain that while there is no need to abandon the received position that man is truly an animal, he is yet the only rational one known to us, and that his rationality constitutes a fundamental distinction-one of kind and not of degree. The estimate we have formed of man's position differs therefore most widely from that of Mr. Darwin.

Mr. Darwin's remarks, before referred to (ante, p. 43) 
concerning the difference between the instincts of the coccus (or scale insect) and those of the ant-and the bearing of that difference on their zoological position (as both are members of the class Insecta) and on that of man-exhibit clearly his misapprehension as to the true significance of man's mental powers.

For in the first place zoological classification is morphological. That is to say, it is a classification based upon form and structure-upon the number and shape of the several parts of animals, and not at all upon what those parts do, the consideration of which belongs to physiology. This being the case, we not only may, but should, in the field of zoology, neglect all questions of diversities of instinct or mental power, equally with every other power, as is evidenced by the location of the bat and the porpoise in the same class, mammalia, and the parrot and the tortoise in the same larger group, sauropsida.

Looking therefore at man with regard to his bodily structure, we not only may, but should, reckon him as a member of the class mammalia, and even (we believe) consider him as the representative of a mere family of the first order of that class. But all men are not zoologists; and even zoologists must, outside their science, consider man in his totality and not merely from the point of view of anatomy.

If then we are right in our confident assertion that man's mental faculties are different in kind from those of brutes, and if he is, as we maintain, the only rational animal; then is man, as a whole, to be spoken of by preference from the point of view of his animality, or from the point of view of his rationality? Surely from the latter, and if so, we must consider not structure, but action.

Now Mr. Darwin seems to concede ${ }^{1}$ that a difference in kind would justify the placing of man in a distinct kingdom,

\section{Descent of Man, vol. i. p. 186.}


inasmuch as he says a difference in degree does not so justify; and we have no hesitation in affirming (with $\mathrm{Mr}$. Darwin) that between the instinctive powers of the coccus and the ant, there is but a difference of degree, and that, therefore, they do belong to the same kingdom; but we contend it is quite otherwise with man. Mr. Darwin doubtless admits that all the wonderful actions of ants are mere modifications of instinct. But if it were not so-if the piercing of tunnels beneath rivers, etc., were evidence of their possession of reason, then, far from agreeing with Mr. Darwin, we should say that ants also are rational animals, and that, while considered from the anatomical standpoint they would be insects, from that of their rationality they would rank together with man in a kingdom apart of ' rational animals.' Really, however, there is no tittle of evidence that ants possess the reflective, self-conscious, deliberate faculty; while the perfection of their instincts is a most powerful argument against the need of attributing a rudiment of rationality to any brute whatever.

We seem, then, to have Mr. Darwin on our side when we affirm that animals possessed of mental faculties distinct in kind, should be placed in a kingdom apart. And man possesses such a distinction.

Is this, however, all that can be said for the dignity of his position? Is he merely one division of the visible universe co-ordinate with the animal, vegetable, and mineral kingdoms?

It would be so if he were intelligent and no more. If he could observe the facts of his own existence, investigate the co-existences and successions of phenomena, but all the time remain, like the other parts of the visible universe, a mere floating unit in the stream of time, incapable of one act of free self-determination or one-voluntary moral aspiration after an ideal of absolute goodness. This, however, is far 


\section{The Descent of Man.}

from being the case. Man is not merely an intellectual animal, but he is also a free moral agent, and, as such-and with the infinite future such freedom opens out before himdiffers from all the rest of the visible universe by a distinction so profound that none of those which separate other visible beings is comparable with it. The gulf which lies between his being as a whole, and that of the highest brute, marks off vastly more than a mere kingdom of material beings; and man, so considered, differs far more from an elephant or a gorilla than do these from the dust of the earth on which they tread.

Thus, then, in our judgment the author of the Descent of Man has utterly failed in the only part of his work which is really important. Mr. Darwin's errors are mainly due to a radically false metaphysical system in which he seems (like so many other physicists) to have become entangled. Without a sound philosophical basis, however, no satisfactory scientific superstructure can ever be reared; and if $\mathrm{Mr}$. Darwin's failure should lead to an increase of philosophic culture on the part of physicists, we may therein find some consolation for the injurious effects which his work is likely to produce on too many of our half-educated classes. We sincerely trust Mr. Darwin may yet live to furnish us with another work, which, while enriching physical science, shall not, with needless opposition, set at naught the first principles of both philosophy and religion. 


\section{EVOLUTION AND ITS CONSEQUENCES.}

\section{A REPLY TO PROFESSOR HUXLEY.}

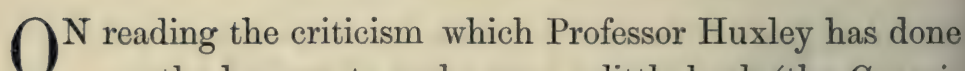
me the honour to make upon a little book (the Genesis of Species) which I ventured to publish in the early part of this year, ${ }^{1}$ I felt that I was being severely reprimanded by my superior officer; that I might apprehend a sentence of degradation to the ranks, if not actual expulsion from the service. I found myself taxed, if not with positive desertion to an enemy with whom no truce is to be allowed, yet, at least, suspected of treasonable communication with a hostile army, and treacherous dalliance with ministers of Baal.

Now, recognising as I do that, in physical science, Professor Huxley has just claims to respect and deference on the part of all scientific men, I also feel that I am under special obligations to him, both many and deep, for knowledge imparted and for ready assistance kindly rendered. No wonder then that the expression of his vehement disapproval is painful to me.

It was not however without surprise that I learned that my one unpardonable sin - the one great offence disqualifying me for being ' a loyal soldier of science'-was my attempt to show that there is no real antagonism between the Christian religion and evolution !

My Genesis of Species was written with two main objects :-

My first object was to show that the Darwinian theory is

$$
{ }^{1} \text { i.e. in } 1870 \text {. }
$$


untenable, and that natural selection is not the origin of species. This was and is my conviction purely as a man of science, and I maintain it upon scientific grounds only.

My second object was to demonstrate that nothing even in Mr. Darwin's theory, as then put forth, and ì fortiori in evolution generally, was necessarily antagonistic to Christianity.

Professor Huxley ignoring the arguments by which I supported my first point, fastens upon my second; and the gist of his criticism is an endeavour to show that Christianity and science are necessarily and irreconcilably divorced, and that the arguments I have advanced to the contrary are false and misleading.

Before replying to Professor Huxley's observations and misconceptions on this head, I may be excused for saying a few words as to my first point, namely, the scientific reasons which seem to oppose themselves to the reception of the Darwinian theory as originally propounded by its author; and here I claim to be acting, and to have acted, as 'a loyal soldier of science' in stating the scientific facts which have impressed me with certain scientific convictions (on purely scientific grounds), in opposition to Mr. Darwin's views.

Professor Huxley does not so much dispute the truth of my conclusions as deny their distinctness from those at which Mr. Darwin himself has arrived, or indeed originally put forth, asserting that my book is but 'an iteration of the fundamental principle of Darwinism.'

I shall then shortly endeavour to show more distinetly wherein my view radically differs from that first propounded by Mr. Darwin, and still maintained, or at least not distinctly repudiated by him; though I believe that the admissions he has of late made amount to a virtual, but certainly not to an explicit, abandonment of his theory.

The Professor expresses his doubt as to the existence of 
an 'absolute and pure Darwinian,'-a doubt which is certainly a surprise to me, as I had always understood him as guarding himself carefully against the identification of his uwn views with those of Mr. Darwin, and as allowing that it was one thing to hold the doctrine of evolution and another to accept the Darwinian hypothesis. In a lecture ${ }^{1}$ delivered in 1868 at the Royal Institution, he observed: ' I can testify, from personal experience, it is possible to have a complete faith in the general doctrine of evolution, and yet to hesitate in accepting the Nebular, or the Uniformitarian, or the Darwinian hypotheses in all their integrity and fulness.'

It is plain then that up to a recent period Professor Huxley distinguished himself from thoroughgoing disciples of $\mathrm{Mr}$. Darwin; implying by this distinction a recognition of the existence of such disciples, pure Darwinians, like those of whom he now ignores the existence.

The very essence of Mr. Darwin's theory as to the 'origin of species' was, the paramount action of the destructive powers of nature over any direct tendency to vary in any certain and definite line, whether such direct tendency resulted mainly from internal predisposing or external exciting causes.

The benefit of the individual in the struggle for life was announced as the one determining agent, fixing slight beneficial variations into enduring characters, and the evolution of species by such agency is justly and properly to be termed formation by 'natural selection.'

That in this I do not misrepresent Mr. Darwin is evident from his own words. He says :-

'If it could be demonstrated that any complex organ existed which could not possibly have been formed by numerous, successive, slight modifications, my theory would absolutely break down.' ${ }^{2}$ Also :

1 See Proceedings of the Royal Institution, vol. v. p. 279.

2 Origin of Species, p. 208. 
'Every detail of structure in every living creature (making some little allowance for the direct action of physical conditions) may be viewed either as having been of special use to some ancestral form, or as being now of special use to the descendants of this form-either directly, or indirectly, through the complex laws of growth ;' and 'if it could be proved that any part of the structure of any one species had been formed for the exclusive good of another species, it would annihilate my theory, for such could not have been produced by natural selection.' 1

Mr. Darwin, as I before ${ }^{2}$ observed, could hardly have employed words by which more thoroughly to stake the whole of his theory on the non-existence or non-action of causes of any moment other than natural selection. For why should such a phenomenon 'annihilate his theory?' Because the very essence of his theory, as originally put forth, is to recognise only the conservation of slight variations directly beneficial to the creature presenting them, by enabling it to obtain food, escape enemies, and propagate its kind.

Such being the case, my first object, as I have before said, was to show not only that 'natural selection' is inadequate to the task assigned it, but that there is much positive evidence of the direct action both of external influences sufficient to dominate and overpower in certain instances the ordinary processes of 'natural selection,' and also of still more influential internal powers; moreover that these latter powers are so efficient as to present themselves as probably the main determining agent in specific evolution, although I admitted that a certain subordinate action of natural selection plainly obtained.

The various arguments I advanced space does not allow me here to reproduce, but referring to my book, I may point out that therein I endeavoured to show:-

1. That no mere survival of the fittest accidental variations can account for the incipient stages of structures useful

${ }^{1}$ Op. cit. p. 220.

${ }^{2}$ See ante, p. 4. 
enough when once developed. Such, e.g., as the whalebone of the whale's mouth, the larynx of the kangaroo, pedicellarix and bird's heads processes, and many other structures.

2. That the sexual colours of apes, the beauty of shell-fish and the complex mechanisms by which fertilisation is effected in many orchids are quite beyond the power of natural selection to develop.

3. That modes of formation, such as in the human eye and ear, in that they spring from simultaneous and concurrent modifications of distinct parts, have a remarkable significance.

4. That the independent origin of similar structures in very different animal forms should be noted, and I adduced evidence to show that similar modifications are sometimes directly induced by obscure external conditions, as in the sudden acclimatisation of English greyhounds in Mexico, and in the loss of the tail in certain butterflies of certain regions, and in the direct modification of young English oysters when transported to the shore of the Mediterranean. Moreover, it was shown that some groups of organic forms exhibit a common tendency to remarkable developments of particular kinds, as is the case with birds of paradise.

5. That facts may be cited to support the theory of specific stability (different in degree in different species), and to demonstrate that reversion may take place in spite of the most careful selection in breeding. The value of the facts of sterility in hybrids was also considered.

6. That data bearing on the relation of species to time may be brought forward, apparently fatal to their origin by the action of natural selection.

7. That the significant and important facts of the deepseated resemblances existing not only between different individual animals, but between different parts of one and the same individual, should be pondered over; these points 
being, as was shown, capable of reinforcement by others drawn from the abnormalities of monstrous births, and the symmetrical character of certain diseases.

From all these considerations, a cumulative argument seemed to me to arise conclusive against the theory that species have had their specific characters fixed solely by the action of ' natural selection.'

The hypothesis which I ventured to offer as my view of the evolutionary process was and is, that just as all admit the universe to have been so ordered —or to so exist — that on the mixing of chemical substances under certain conditions new and perfectly definite species of minerals are suddenly evolved from potentiality to existence, and as by the juxtaposition of inorganic matters under certain influences ${ }^{1}$ a new form of force - 'vitality'-appears upon the scene-so also in animals, the concurrence of certain external exciting causes acts in such a manner on internal predisposing tendencies as to determine by a direct seminal modification the evolution of a new specific form. The action of 'natural selection' I admitted, and admit, to be real and necessary, but I ascribe to it an altogether subordinate rôle.

This view may be true or false, but it is a very different one from that advocated by the author of the Origin of species, and I am at a loss to understand how Professor Huxley can consider it identical with Mr. Darwin's, more especially as (at p. 237) I have enumerated the points in which my theory coincides with Professor Owen's Derivation and differs from that of the author of the Origin of Species. It seems to me strange that Professor Huxley should now assert the 'very pith and marrow' of Darwinism to have been the affirmation that 'species have been evolved by variation,

1 Though Professor Huxley is disinclined as yet to admit that such evolution of living thing takes place now, he none the less admits the principle, though he relegates such evolution to a remote epoch of the world's history. See 'Address to the British Association, Liverpool, 1870,' p. 17.

VOL. II. 
aided by the subordinate action of natural selection,'-when he himself in his Lay Sermons (p. 321) has enunciated simply that Mr. Darwin's hypothesis is the origin of species ' by the process of natural selection,' without one word of qualification; and five pages further on, has considered the possibility of the refutation of Mr. Darwin's view by the discovery of residual phenomena' ${ }^{1}$ not explicable by 'natural selection'-just such phenomena as I have endeavoured to call attention to in my book.

I question whether Mr. Darwin even now does admit that 'natural selection' has only a subordinaté action. I do not recollect to have met with such a declaration, although I think that it should logically follow from the various admissions he has latterly made. If he does admit it, then a cause which is subordinate cannot be the determining agent. If he does not admit it, then there is a radical difference between my hypothesis and Mr. Darwin's.

Professor Huxley blames the Quarterly Reviewer's treatment of Mr. Darwin as 'unjust and unbecoming,' because he endeavours to show how Mr. Darwin has changed his ground without (in spite of his generally scrupulous candour) disavowing 'natural selection' as the origin of species.

I confess that it seems to me that the reviewer was fully justified in so doing; for Mr. Darwin's reputation as a man of science stands so high, that it was plainly the reviewer's duty to endeavour to prevent the public attaching, in mere deference to Mr. Darwin's authority, a greater weight to his assertions than the evidence adduced warranted. The reviewer sought to do this by showing, by Mr. Darwin's own words, he had been compelled to admit that 'abrupt strongly marked changes' may occur 'neither beneficial nor injurious' to the creatures possessing them, produced 'by unknown

1 His words are- 'What if species should offer residual phenomena, here and there, not explicable by natural selection?'-Lay Sermons, p. 326. 
agencies' lying deep in 'the nature of the organism.' In other words, that Mr. Darwin has in fact, ${ }^{1}$ though not in express words, abandoned his original theory of the 'origin of species.'

I am grateful, however, to Professor Huxley for having spoken of 'injustice' in connection with Mr. Darwin. I am so because it affords me an opportunity for declaring myself more fully with respect to the distinction between Darwinism and Mr. Darwin.

In common, I am sure, with all those who have been privileged to know not only Mr. Darwin's works, but Mr. Darwin hinself, I have ever entertained, and shall continue to entertain, for that amiable gentleman and most accomplished naturalist the warmest sentiments of esteem and regard. Convinced as I am that he is actuated by a pure love of truth, admiring, nay, venerating him for his acute, his unwearied, and widely-extended researches, it has been to me a most painful task to stand forth as his avowed and public opponent.

The struggle between my inclination to praise and to acquiesce, and my sense of duty which impelled me to dissent, led me to express myself very imperfectly, and I thank Professor Huxley for thus giving me occasion to acknowledge my regret that these sentiments should have led me to give such very inadequate expression to my dissent from, and reprobation of, Mr. Darwin's views, especially as manifested in their later developments.

$x$ Professor Huxley now tells us that Mr. Darwin is inclined to admit that varieties can 'be perpetuated, or even intensified, when selective conditions are indifferent, or perhaps unfavourable' to their 'existence.' Surely, if species may be evolved in the teeth of all the opposition 'natural selection' can offer, it is, to say the least, somewhat paradoxical to affirm that nevertheless natural selection is their cause. For all this Mr. Darwin has not, I believe, expressly said that the action of 'natural selection' is only subordinate, though he implies that it is but co-ordinate. So that though he has virtually given up his original theory, his view does not yet coincide with mine, as far as I can gather from his words. 
As to the principles embodied in Mr. Darwin's Origin of Species, the further study of them more and more brings home to me their unsatisfactoriness, as pointed out by me in my Genesis of Species. Indeed, 'natural selection,' as the agent for the determination of specific animal forms, is, I am convinced, utterly insufficient to the task assigned it; while the reasoning employed in the Descent of Man to support the hypothesis of our ape origin ${ }^{1}$ seems to me, to say the least, unworthy of Mr. Darwin's earlier productions.

Professor Huxley attributes to the Quarterly Reviewer 'peculiar notions of probability,' because he affirms that if all animals below man have been evolved one from the other, then a close resemblance in man's body to any particular animal's does not increase that à priori probability as to his bodily evolution, which springs from the fact of his being ' an animal at all.' But surely if it was of the essence of an animal to be 'evolved,' so that to be an animal implied being a creature formed by evolution, then the fact of man being an animal would necessarily have a similar implication, and I fail to see what additional force that probability would obtain through any particular resemblance. On the other hand, if there is authority for believing that man's body was miraculously created, such particular resemblance would not render such a miracle one bit less credible; for there is no necessity, on the hypothesis of such miraculous creation, for more than even a specific difference between his body and that of some other animal.

Professor Huxley also speaks of the Quarterly Reviewer's making the admission as to the similarity of man's body to that of brutes 'grudgingly.' With regard to myself, no one is better aware than Professor Huxley how I have worked at

1 The much ridiculed Lord Monboddo has been successfully redeemed from very unjust depreciation in an interesting article which has lately appeared. See the Month for November 1871. 
the demonstration of the close resemblance which exists between the bodily structures of men and apes.

Another objection is brought both against me and the Quarterly Reviewer by Professor Huxley. We are declared to make a 'conspicuous exhibition' of the 'absence of a sound philosophical basis,' in that we agree in asserting that man differs more from an ape than does an ape from inorganic matter.

But surely this is the position every one must assume who believes that man is immortal, and has a moral responsibility to God. For it is manifest that such distinctions (e.g. as to growth, nutrition, locomotion, etc.) as exist between apes and minerals are as nothing compared with the transcendent distinction above referred to. If, then, in saying this we are in 'philosophical error,' we share that error with all those who assert the immortality of the soul, and a moral responsibility of each man to God, such as no brute possesses. We can also claim as more or less on our side even one of the originators of the theory of 'natural selection' itself, and his followers. For Mr. Wallace, if I understand him rightly, teaches us that for the evolution of man's body special spiritual agencies were required, which were not needed for the rest of the organic world. So that, according to this view, man is marked off from all the rest of nature by a very special distinction.

I will turn now to the main point of Professor Huxley's paper-namely, that in which he applies himself to controvert the second object aimed at in my Genesis of Species. As I have before said, my second object was to demonstrate that there is no necessary antagonism between the Christian religion and evolution.

In meeting me on this ground (to discuss which seems to have interested the Professor more than anything else in my book), he endeavours to create a prejudice against my argu- 
ments, and to narrow my base, by representing me as a mere advocate for specially Catholic doctrine. ${ }^{1}$

I altogether decline to allow the issue to be thus limited. I decline it because neither did I intend such limitation, nor do any words of mine justify such a construction of my purpose. I took up, and I take up, only the ground common to me and to all who hold the Christian religion as expressed in the Apostles' Creed, or who maintain the inspiration of Scripture. The better to make sure of my position I made use of an extreme case, knowing that if I could maintain even that, then all within that extreme term could not certainly be questioned. Purposely then I set out to show, and I did show, that even the strictest Ultramontane Catholics are perfectly free to hold the doctrine of evolution, thereby making evident that with regard to Christians in general, there could not be a doubt as to their freedom in the matter. For this end I expressly selected just such persons as would commonly be supposed not to be those from whom (in Professor Huxley's words) 'modern science was likely to receive a warm welcome,' and amongst others the Spanish Jesuit, Father Suarez, precisely because, as Professor Huxley says, 'the popular repute of that learned theologian and subtle casuist was not such as to make his works a likely place of refuge for liberality of thought.'

My critic shows how he misapprehends my aim and intention when he speaks of 'Mr. Mivart citing Father Suarez as his chief witness in favour of the scientific freedom enjoyed by Catholics.' Had he been such a witness I should not for one moment have thought of citing him; it was precisely as one of the most rigid theologians, and of

1 At p. 454, Professor Huxley gives the words 'Catholic theology' with marks of quotation as if mine, though in fact they were not so. This typographical error does not misrepresent my substantial meaning, but it none the less tends to create a prejudice against my statements in the mind of the public. 
'unspotted orthodoxy' (as Professor Huxley justly remarks), that I called him into court, where he testifies so completely to my satisfaction.

The success of my mode of procedure is, I confess, gratifying to me. Not only was my argument 'most interesting' to Professor Huxley, but he tells us his 'astonishment reached its climax,' and that he shall 'look anxiously' for additional references 'in the third edition of the Genesis of Species.' Fortunately I have no need to keep the Professor waiting, but shall shortly proceed to give him these additional references at once.

Let it be borne in mind that in view of the popular conceptions current in England on the subject, my argument was that if even those who receive the teaching of St. Thomas Aquinas and the Jesuits, and who look to Rome for doctrinal decisions - if even those are free to accept evolution, then, a fortiori, other Christians, supposed to be comparatively untrammelled, need not hesitate as to the harmony and compatability of Christianity and evolution.

Of all I said in my book on the subject I have nothing to retract; but I repeat yet more confidently than before that 'evolution is without doubt consistent with the strictest Christian theology': that 'it is notorious that many distinguished Christian thinkers have accepted, and do accept, both ideas'; that 'Christian thinkers are perfectly free to accept the general evolution theory'; and, finally, that 'it is evident that ancient and most venerable theological authorities distinctly assert derivative creation, and thus their teachings harmonise with all that modern science can possibly require.

The point I had to prove was that the assertion of the evolution of new species (whether by Mr. Darwin's 'natural selection' or according to my hypothesis) was in no opposition to the Christian faith as to the creation of the organic world. 
In order to prove this I had to consider the meaning of the word 'creation,' and I found that it might be taken in three senses, with only two of which, however, we had to do.

The first of these was direct creation out of nothing, of both matter and form conjoined-absolute creation such as must have taken place when the earliest definite kind of matter appeared.

The second was derivative or potential creation: the creation by God of forms not as existing, but in potentia, to be subsequently evolved into actual existence by the due concurrence and agency of the various powers of nature.

Searching for information on the subject, I found to my surprise that the regular teaching of theology adopted this view, which was maintained by a complete consensus of authorities. Of these I purposely chose but a few telling ones as types; and, amongst the rest, Suarez, who without any doubt, and as I shall proceed to demonstrate more at length, is a thorough-going supporter of it.

Professor Huxley has quite misapprehended ${ }^{1}$ my meaning, hence the disappointment he speaks of. What he did not find, I never said was to be found. What he actually did find is what everybody knew before, but is a matter totally different from, and utterly irrevelant to, the point I maintained.

My critic fails to distinguish between the question as to the nature of creation as an act, and that concerning the fact of creation.

1 Not only this, but he has even misrepresented my words. He says (p. 445) : 'According to Mr. Mivart, the greatest and most orthodox authorities upon matters of Catholic doctrine agree in distinctly asserting "derivative creation" or "evolution" "-as if 'derivative creation' and 'evolution' were the same thing. Having thus made me enunciate what I never thought of, consequences are deduced which, of course, are not of my deducing. Derivative or potential creation such authorities do assert : evolution of species, however, was no more thought of in their days than the electric telegraph. 
Now, what my intention was is plainly shown by the words I used. I said: 'Considering how extremely recent are these biological speculations, it might hardly be expected it priori that writers of earlier ages should have given expression to doctrines harmonising in any degree with such very modern views; nevertheless this is certainly the case.' And so it is.

Of Suarez I said, he opposes those who maintain the absolute creation of substantial forms, and he distinctly asserts derivative (potential) creation. And this is true.

Although Professor Huxley has conveyed the impression that I adduced Suarez as a witness to evolution, I cannot think he intended so to do. He surely could not have inagined me so absurd as to maintain that ancient writers held that modern view; to attribute to them the holding of such a conception would be to represent them as nothing less than inspired. For certainly no notion of the kind could have been present, even in a dream, to the minds of such thinkers. In their eyes (as in the eyes of most till within the last century) scientific facts must have seemed to tell in the opposite direction.

All I maintained, and all that I thought any one could have supposed me to maintain, was that these writers asserted abstract principles which perfectly harmonise with the requirements of modern science, and have, as it were, provided for the reception of its most advanced speculations.

My words were: 'The possibility of such phenomena, though by no means actually foreseen, has yet been fully ymovided for in the old philosophy centuries before Darwin.' And that this is the case can be proved to demonstration. The really important matter, however, is not what were my expressions, but what is the fact as to the compatability of evolution with the strictest orthodoxy? We shall see how, by Professor Huxley's very fortunate misapprehension of my 
meaning, this truth will be brought out yet more clearly than before.

Far from maintaining that Suarez was a teacher of development or evolution, what I quoted him for was this :-

I. As an opponent of the theory of a perpetual, direct creation of organisms (which many held, and still hold).

II. To show that the principles of scholastic theology are such as not to exclude the theory of development, but, on the contrary, to favour it, even before it was known or broached.

What Professor Huxley quotes in his article amply confirms my position. For if there are innumerable substantial forms in the potentia of matter, which are evolved according to the proximate capacity of matter to receive such forms, it is evident that if the organisation of matter, through chemical or other causes, progresses by the ever-increasingly complex re-actions between bodies and their environment, then it necessarily follows that new and higher substantial forms may be evolved, and consequently new and higher forms of life.

Such a principle, firmly established against opponents, becomes applicable to the evolution of new species, as soon as ever physical science shows good reason to regard the origin of species not as simultaneous but successive.

It may be objected that Suarez, in the passage referred to, only adverts to new individuals of known kinds in the ordinary course of nature. Professor Huxley says: 'How the substantial forms of animals and plants primarily originated, is a question to which, so far as I am able to discover, he does not so much as allude in his Metaphysical Disputations.' Most certainly, in his day, no one entertained the modern notion as to origin of species; and it was hardly to be expected that Suarez should say anything directly in point. That he should establish the needful principle was all we could reasonably demand or expect. 
Nevertheless, in a remarkable manner, even Father Suarez does refer to the origination of certain kinds of animals, and admits their actual evolution by natural causes. These are partly exceptional forms such as hybrids, and partly such as were believed to originate by cosinical influences direct from the inorganic world, or through the agency of putrefaction.

In lib. ii., De Opere Sex Dierum, c. x., n. 12, speaking of such animals as the mule, leopard, lynx, etc., after stating the opinion that individuals of their kinds must have been created from the beginning, he says, 'nihilominus contrarium censeo esse probabilius'; and he gives his reason, 'quia hujusmodi species animalium sufficienter continebantur potentialiter in illis individuis diversarum specierum ex quorum conmixtione generantur; et ideo non fuit necessarium aliqua eorum individua $a b$ auctore naturæ immediate produci.' This in principle is absolutely all that can be required, for it reduces the matter simply to a question of fact. $\mathrm{He}$ asserts the principle that those kinds of animals which are potentially contained in nature need not be supposed to be directly and immediately created. In determining what kinds were or were not so contained, he followed the scientific notions of his time as he understood them. He would have written according to the exigencies of science now.

But this matter is really unmistakable. For, so far was Suarez from teaching that all life requires direct creative action, that he speaks of certain creatures, 'quæ per influentiam cœlorum ex putrida materia terræ aut aqua generari solent.' (Tbid., n. 10.)

It is also interesting to see that (in n. 11) he positively asserts the improbability and incredibility that certain kinds of animals now living were actually created at first at all: 'Alias dicendum esset in omnibus speciebus quantumvis imperfectis aliqua individua in principio fuisse facta quia non 
est major ratio de quibusdam quam de aliis. Consequens est incredibile.' He then instances certain insects, but as far as the principle of evolution in itself is concerned he might as well have selected crocodiles.

Moreover, with respect to certain vegetable productions he says (ib. c. vi. n. 1), 'an vero hujusmodi herbæ sint factæ hoc die tantum in potentia vel etiam in actu magis dubitari potest.' Finally, even with regard to the production of animals altogether, he tells us that it was not a real creation (c. x. n. 3), 'sed ex præjacente materia modo tamen proprio auctoris naturæ.' It is strange that Professor Huxley should have overlooked these passages, which so directly contradict his assertions.

Nevertheless these passages are not, let it be recollected, adduced to show that Suarez held the doctrine of evolution, or that he maintained as a fact that species were evolved, except in peculiar cases, or that he took St. Augustin's view as to the fact of creation; but to demonstrate that he distinctly admits principles compatible with evolution, and that even where he asserts direct and immediate divine action, yet that even there the exceptions he admits bring out still more clearly how completely I was justified in adducing him as a witness to the compatability of evolution with the principles of the scholastic philosophy.

So much then for the teaching of Suarez as to the nature of the creative act and the admission of the evolution of even certain new organic forms by natural causes.

Let us turn now to a much more important subject.

Besides and in addition to this view it is a most remarkable circumstance that ideas should have been expressed of a distinctly evolutionary character by the highest theological authority, even as regards the very fact of creation, as an historical event.

Few things seem to me more striking than that such an 
anticipation, as it were, should have been enunciated by one of the greatest teachers the Church has ever known, a doctor, the authority of whose writings is not surpassed by that of any of the Fathers-I mean St. Augustin. As I said in my book, 'it must be borne in mind that no one had disputed the generally received belief as to the small age of the world, or of the kinds of animals and plants inhabiting it.' Nevertheless, as I have shown, the teaching of St. Augustin was distinct with respect to the potential creation of animals and plants. That great source of Western theology held that the whole creation spoken of in Genesis took place in one instant; that all created things were created at once, 'potentialiter atque causaliter,' so that it accords with his teachings if we believe in the gradual development of species, the slow evolution, 'per temporum moras,' into actual existence of what God created potentially in the beginning.

Now the greatest representatives of Catholic theology are unquestionably St. Augustin and St. Thomas Aquinas, and this being, as almost every one knows, the case, it is inconceivable how a teacher like Professor Huxley could write as he has done regarding the consequences of a divergence of Suarez from their expressed opinions.

If, as Suarez suggests, St. Thomas followed St. Augustin rather through deference than from identity of opinion, it would only bring out more strongly the paramount authority of the latter. But in fact Suarez was here mistaken, for we have St. Thomas's own words as to the matter, where, speaking of St. Augustin's view, he tells us, 'et hæc opinio plus mihi placet' (2 Sent. dis. 12, quæst. 1, a. 2).

Here it may be well to explain (as Professor Huxley seems quite to have misapprehended me), that when I spoke of the 'wide reception' of Suarez, and of his being 'widely venerated ' and of 'unquestioned orthodoxy,' I never thought of placing him on a level with St. Thomas and St. Augustin. 
Moreover, 'wide veneration' and 'orthodoxy', by no means imply authority in the sense of binding consciences. Many Catholic teachers altogether reject the teaching of Suarez on certain points, though they none the less consider him an authority to be respectfully consulted, indeed, but by no means to be necessarily followed.

Multitudes of teachers, all agreeing in matters of faith, yet belong to very different theological schools, and the idea that any one of them can bind the others, is simply laughable to those who know anything about the matter.

Professor Huxley seems to imagine that in showing that Suarez (like most teachers of his day, Catholic or not, e.g. Tycho Brahe) adopts an extreme literalism of Scripture interpretation, he has made a notable discovery. But (as before remarked) I referred to Suarez for principles of interpretation with regard to derivative creation, and his views as to the historical facts of Genesis are quite beside the question. St. Thomas explains the diversity of opinion among theologians in a way which exactly meets my purpose: 'Quoad mundi principium, aliquid est quod ad substantiam fidei pertinet scilicet mundum incepisse creatum et hoc omnes sancti concorditer dicunt. Quo autem modo et ordine factus sit non pertinet ad fidem nisi per accidens, in quantum in Scriptura traditur, cujus veritatem diversa expositione sancti salvantes diversa tradiderunt' ( 2 Sent., dist. 12 , q. 1, a. 2).

My critic also appears to think that, because one side of a question is perfectly orthodox, its contradictory cannot be so likewise. If he knew the A B C of Catholic doctrine, he would know that in open questions it is perfectly allowable to maintain either side.

Professor Huxley says that Suarez in this question (as in other matters) is in opposition to St. Augustin. He is so; but other theologians of equal weight severely took him to 
task for his expressions on this subject, as I shall proceed to show, and there is not the slightest difficulty in bringing forward many theological authorities, both before and since the time of Suarez, who approve or positively affirm the position which St. Augustin took. Therefore, even if I had made the mistake which Professor Huxley supposes I had, it would not be of the slightest moment, and my thesis could repose as securely on the support of other theologians.

Thus I may mention St. Thomas, St. Bonaventure, Albertus Magnus, Denis the Carthusian (1470), Cardinal Cajetan (1530), Melchior Canus (1560), Bannes (1580), Vincentius Contenson (1670), Macedo and Cardinal Noris (1673), Tonti (1714), Serry (1720), Berti (1740), and others down to the present day.

St. Bonaventure calls St. Augustin's exposition 'multum rationabilis et valde subtilis,' and speaks of his method as a 'via philosophica'; nay, he calls the contrary opinion 'minus rationabilis quam alia' (Librum secund. Sent. dist. xii. quæst. ii, art. 1 conclusio).

St. Thomas, as I have shown, supports and approves St. Augustin, but he even admits ('Summ.' par. i. quæst. lxxiii. art. 1, ad. 3) the possibility of the evolution of new species. He says :- 'Species etiam novæ si quæ apparent, præextiterunt in quibusdam activis virtutibus sicut et animalia ex putrefactione generata producuntur ex virtutibus stellarum et elementorum quas a principio acceperunt, etiam si novæ species talium animalium producuntur.'

Professor Huxley will hardly dispute the weight and significance, in this controversy, of the distinct adoption of St. Augustin's view by an eminent Roman Cardinal of the latter part of the seventeenth century.

Yet Cardinal Noris (Vindicioe Augus., c. iv. § ix.; see Migne's Patrologice Cursus Completus, tom. xlvii. p. 719) speaks in the following uncompromising words:- 
'Hic etiam recentiorum querelæ, imo censura, quibus insignem Sancti Doctoris interpretationem in cap. i. Geneseos excipiunt, refellendæ sunt. . . Augustinus, quod videbat sex priores dies queis Moyses mundum a Deo creatum scribit, si litteraliter accipiantur, gravissimis difficultatibus subjici, quas ipsemet in libris de Genesi ad litteram proponit, subtilem prorsus ac se dignam sententiam excogitavit, nempe dies illos intelligendos esse mystice, juxta cognitionem angelicam de rebus in Deo, et in proprio genere, et juxta ordinem rerum simul a Deo creatarum, dierum etiam ordinem in angelorum mente designavit. . . . . Ex nostris scriptoribus Magister Emmanuel Cerda Lusitanus, publicus in Academia Conimbricensi theologiæe professor, in suis Quodlibetis theologicis, acerrime contra recentiorum impetum Magni Parentis sententiam propugnat, eorumque et in censurando audaciam, et in impugnando debilitatem ostendit; idem quoque prestitit Carolus Moreau, noster Bituricencis in vindiciis pacificis.'

Speaking of Cornelius à Lapide, he adds :-

'Verum Augustino consentit Albertus, qui ob multiplicem ac mirabilem litteraturam Magni cognomento insignitus fuit, his plane verbis ; sine præjudicio sententiæ melioris videtur Augustino consentiendum. Part I. Summæ q. 12, de quatuor coævis. Addit Sanctus Thomas proxime laudatus: Hæc opinio (Augustini) PLUS MIHI PLACET. Itane Cornelii sententia illa, quam Albertus Magnus ac sanctus Thomas, Scholasticorum lumina ac columnæ, probant et sequuntur, hac ætate erronea evasit? Quænam illam Synodi, qui Romani præsules, quæ doctorum academiæ proscripsere? An quia tibi tuisque displicet erronea censenda est?..... Num Sanctus Thomas, Albertus Magnus, Sanctus Bonaventura, et Egidius Romanus inter accuratiores theologos minime recensendi sunt? Eruntne illi de ultima theologorum plebe, Senatores vero Suarez, Molina et Martinon? Imo omnium nobilissimi illi sunt quibus et Suarez et Molina assurgant, Martinon vero nec eadem cum illis die nominetur.'

Berti, who was Assistant-General of his order, who published his book at Rome, and belongs to a period more than half a century later than Cardinal Noris, proposes the following thesis (De Theologicis Disciplinis, lib. xi. c. ii.) :- 
- Propositio I. Audaciæ potius et fidentiæ vitio, quam doctrinæ laude debent notari, qui maledico dente carpunt Augustianam de simultanea creatione sententiam.

'Propositio II. Augustini de simultanea creatione sententia non solum ab omni animadversione immunis est, verum etiam probabilis et prope certa.'

\section{And in n. 9 he says:-}

'Quare in distributione operum Dei omnia quidem spectant ad illos dies invisibiles in quibus creavit omnia simul, videlicet ad diversas cognitiones angelorum; sed plura, hoc est, quæ primum in rationibus seminalibus, deinde visibiliter facta sunt si accipiantur secundum priorem conditionem, pertinent ad dies intelligibiles, et unico momento fuerunt et ipsa producta ; si vero inspiciantur, ut in propria forma aspectabili constitutæ, istorum creatio perficitur in tempore, et post sex illos dies invisibiles; spectatque ad dies naturales in quibus Deus operatur quotidie, quidquid ex illis tanquam involucris primordialibus in tempore evolvitur. Sed legite S. Patrem Lit. v. de Gen. ad lit.'

But now, coming down to our own day, the same complete refutation of Professor Huxley's position is most easily effected.

Father Pianciani, a Jesuit, was president of the College of Philosophy in the Roman University. His work, Cosmogonia Naturale Comparata al Genes., was published at Rome in 1862, at the press of the 'Civiltà Catholica.' Professor Huxley will hardly dispute as to his orthodoxy. This author, in his Historia Creationis Mosaicae (published at Naples as long ago as 1851), p. 29, shows that the whole of the first chapter of Genesis must be read as a most sublime and magnificent poetical description. Concerning St. Augustin's special view, he tells us (p. 15), 'Ejus doctrina ad hæc capita revocatur':-

' $1^{0}$ Omnia simul a Deo fuisse producta : $2^{0}$ Cum ipsa ita disponi queant, ut infimum gradum materia elementaris; supremum puri spiritus occupent, interjectos et medios tum mixta, seu chimica composita, tum corpora physice composita, ut saxa, tum præcipue corpora

VOL. II. 
organica. Hinc quæ ad infimum, supremumque gradum spectant et si quæ alia sunt, quæ naturæ viribus neque nunc producuntur, plene et perfecte tunc fuisse producta; quæ vero interjectis gradibus continentur et nunc naturæ viribus producuntur, virtute duntaxat et et seminaliter seu causaliter, tunc Dei imperio extitisse. Augustini opinio, semper ab errore immunis habita, pluribus placuit theologis quos inter Albertus Magnus. St. Thomas in Summa, p. 1, q. 74, a. 2 - eam reveretur, et nec ipsi nec vulgari doctrinæ præjudicandum censet, p. 15, 16 .'

No liberal-minded man can see with anything but regret how eagerly Professor Huxley endeavours to restrict within the narrowest limits the faith of the greater part of the Christian world, saying, 'I, for one, shall feel bound to believe that the doctrines of Suarez are the only ones which are sanctioned by authority;' etc.

But the attempt to represent that such literalism is binding on Catholics is simply preposterous. There is no need for the present Archbishop of Westminster to give any such permission as Professor Huxley speaks of (as to the six days), because such freedom existed long before His Grace occupied the see, and was accepted by his predecessor, Cardinal Wiseman. It would be restriction, not freedom, which could alone require him to make any declaration on the subject.

We might really suppose that at this day it would be superfluous to assert that Catholics are free and unembarrassed in their geology and palæontology. But that I may not seem to shirk a point on which the Professor lays such stress, namely, the 'six days' of creation, I will say a few words as to the position of Catholics with regard to this matter.

Now, authorities showing the freedom of Catholics in this respect are so numerous, that it is only difficult to choose. In the first place we have St. Augustin and his many followers, also St. Hildegard, Bertier, Berchetti, Ghici, Robebacher, and Bossuet. Cardinal Cajetan says distinctly that 
the six days were not real days, but meant to indicate order. And I may cite also Cardinal Gousset, Théol. Dogmatique, t. i. p. 103, seq.; Frayssinous, Défense du Christianisme, conf. Moïse, Historien des Temps Primitifs; Perrone, S.J., Proelect. Theol., vol. i. p. 678 (édit. Migne, 1842). But it is really needless to speak of writers during the last few years, for books are daily printed at Rome with the permission of authority such as Perrone, just mentioned, also Tongiorgi and Pianciani (Cosmogonia Naturale, p. 24), before referred to. In English we have Cardinal Wiseman's Science and Revealed Religion, Lectures v. and vi., and only last year a similar work was published in London by the Rev. Dr. Gerald Molloy.

So much for the question of the six days. But before leaving the subject of Christianity and Evolution, there is yet one more point which it may be well to notice. With respect to the hypothesis I advanced that Adam's body might have been formed by evolution like those of other animals, the soul being subsequently infused, Professor Huxley remarks :-

'If Suarez is any authority it is not Catholic doctrine. "Nulla est in homine forma educta de potentia materiæ " is a dictum which is absolutely inconsistent with the doctrine of the natural evolution of any vital manifestation of the human body. Moreover, if man existed as an animal before he was provided with a rational soul, he must, in accordance with the elementary requirements of the philosophy in which Mr. Mivart delights, have possessed a distinct sensitive and vegetative soul or souls. Hence, when the "breath of life" was breathed into the manlike animal's nostrils, he must have already been a living and feeling creature. But Suarez particularly discusses this point, and not only rejects Mr. Mivart's view, but "adopts language of very theological strength regarding it."'

Professor Huxley then quotes from Suarez a passage ending 'ille enim spiritus, quem Deus spiravit, anima rationalis fuit, et PER EAMDEM FACTUS EST homo vivens, ET CONSEQUENTER, ETIAM SENTIENS,' and a conciliar decree condemning the assertion of the existence of two souls in man. 
It is surely not less prudent than it is just, to refrain from speaking authoritatively of that which we have not studied and do not comprehend. The fact is that Professor Huxley has completely misapprehended the significance of the passages he quotes. No wonder if reasoning perfectly lucid to those who have the key appears a mere 'darkening of counsel' to those who have not mastered the elements of the systems they criticise.

To say that Suarez 'rejects Mr. Mivart's view' is absurd, because no such view could by any possibility have been present to the mind of any one of his day. To say that anything in the passage quoted is, even in the faintest degree, inconsistent with that view, is an utter mistake. This is plain from the doctrine as to the infusion of every soul into every infant, which was generally received at the period when Suarez wrote.

This doctrine was that the human foetus is at first animated by a vegetative soul, then by a sentient soul, and only afterwards, at some period before birth, with a rational soul. Not that two souls were supposed ever to coexist, for the appearance of one was thought to coincide with the disappearance of its predecessor-the sentient soul including in it all the powers of the vegetative soul, and the rational soul all those of the two others. The doctrine of distinct souls, which Professor Huxley attributes to me as a fatal consequence of my hypothesis, is simply the doctrine of St. Thomas himself. He says (Quæst. lxxvi., art. 3, ad. 3) :- 'Dicendum quod prius embryo habet animam quæ est sensitiva tantum, qua ablata advenit perfectior anima quæ est simul sensitiva et intellectiva ut infra plenius ostendetur.' Also (Quæst. cxviii., art. 2, ad. 2) :'Dicendum est quod anima præexistit in embryone, a principio quidem nutritiva, postmodum autem sensitiva et tandem intellectiva.' 
He then answers the objection that we should thus have three souls superposed, which he says is false because :-

'Nulla forma substantialis accipit majus aut minus, sed superadditio majoris perfectionis facit aliam speciem sicut additio unitatis facit aliam speciem in numero. ... Ideo dicendum quod cum generatio unius sit corruptio alterius, necesse est dicere quod tam in homine quam in animalibus aliis, quando perfectior forma advenit fit corruptio prioris, ita tamen quod sequens forma habet quidquid habebat prima et adhuc amplius.... Sic igitur dicendum quod anima intellectiva creatur a Deo in fine generationis humanæ quæ simul est et sensitiva et nutritiva corruptio formis præexistentibus.'

Now I am not saying anything about the truth of this doctrine, but only that it perfectly harmonises with the hypothesis thrown out; while that it was the doctrine generally held in Suarez's day should be known to every one who writes upon such a subject at all. This agreement between the doctrine and the hypothesis will readily be apprehended, for if Adam was formed in the way of which I suggested the possibility, he would, till the infusion of the rational soul, be only animal vivens et sentiens, and not 'homo' at all. But when the rational soul was infused, he thereby, as Suarez justly says, 'factus est homo vivens, et consequenter, etiam sentiens.'

The dictum 'Nulla est in homine forma educta de potentia materix' is nothing to the point, because I never supposed that the 'forma rationalis' was in potentia materiæ, but only the 'forma sentiens,' which would disappear and become non-existent as soon as the 'animal,' by the infused rationality, becomes 'homo.' Thus, so far from being inconsistent with my hypothesis, it supports it; for the dictum must have been applied by Suarez to every child, the 'forma sentiens' of which he must have allowed to be 'educta de potentia materiæ.' Professor Huxley has read Suarez ad hoc, and evidently without the guidance of any one familiar with that author, or with his philosophy, and the necessary 
consequence of writing on such a subject under such circumstances follows of course.

I think that it must now be plain to all readers from the passages referred to, that there is perfect freedum for even the very strictest Christians, not only as regards the question of the six days, but also with respect to the full doctrine of Evolution.

Professor Huxley, indeed, must know well that, in addition to the authority of approved writers of ancient and modern times, there is a living authority in the Church. That authority, moreover, is ready at any moment to condemn heresy in the published expressions of any of her children, and certain to detect it; the question as to such views as Evolution being tenable, solvitur ambulando. The Professor congratulates himself prematurely on the 'spontaneous retreat of the enemy from nine-tenths of the territory which he occupied ten years ago.' Not one step backwards has been taken by the enemy Professor Huxley seems to detest above all. In proof of this I can refer to the Rambler of March 1860, wherein a position was at once taken up which is substantially identical with that which I maintain now.

A word as to what I cannot but consider the very regrettable animus which Professor Huxley displays in this matter. We have been accustomed to hear again and again the assertion that men of science differ from the devotees of theology, in that they enter on their inquiries oequo animo, free from prejudice, ${ }^{1}$ and desirous only of truth. Believers have been warned, usque ad nauseam, that a wish to believe vitiates all their arguments. But what weight can we attach to Professor Huxley's conclusions when he tells us, with regard to the doctrine of Evolution, that 'the position of complete and irreconcilable antagonism which, in his opinion, it occupies to the Catholic Church, is "one of its

${ }^{1}$ See Professor Tyndall's Fragments of Science, p. 167. 
greatest merits in my eyes."' A similar, though less striking, theological prejudice is also exhibited by Mr. Darwin himself. $\mathrm{He}$ tells us, in his Descent of Man, with characteristic candour, that in his Origin of Species his first object was 'to show that species had not been separately created,' and he consoles himself for admitted error by the reflection that ' $I$ have at least, as $I$ hope, done good service in aiding to overthrow the dogma of separate creations.' ${ }^{1}$

I have already refused to allow that I contend for less than the intellectual and religious interests of all Christians. But, in fact, I may claim a yet wider sympathy; for in my book I have supported the dogma of Creation as against all those who decline to assert the existence of a God, on the one hand, or those who identify Him with the Creation on the other; and I have endeavoured to uphold the Theistic conception as opposed to Antitheism ${ }^{2}$ and Pantheism respectively.

Professor Huxley tells us that the necessity of a belief in a personal God, in order to a religion worthy of the name, 'is a matter of opinion'! Of course the word may be employed in some unusual sense. I recollect reading of a certain Emersonian who, having accompanied his wife to see Fanny Elssler dance, and being charmed, remarked to her during the performance- 'Margaret, this is poetry.' To which his wife replied-'No, Paul, it is religion!' Of such religion I willingly make a present to Professor Huxley. But, apart from such bizarre employments of the word, I firmly adhere to my proposition. I know that Buddhism is sometimes asserted to be atheistic, but the conception of a power or

1 I am indebted to Mr. Chauncey Wright for calling my attention to this remark, which had escaped my notice.

2 By Antitheism I mean that opinion which is opposed to theism, without dogmatically denying the existence of God. Antitheists deny that we can make any assertion whatever about that which underlies phenomena, and which they term the 'unknowable.' 
principle apportioning after death rewards and punishments, according to a standard of virtue, necessarily involves the existence of an entity, which, as being most powerful, intelligent, and good, is virtually, and logically, a personal God, whatever be the name habitually applied to it.

I do not know what precise meaning Professor Huxley would give to the word religion. He speaks of "worship, "for the most part of the silent sort," at the altar of the Unknown and the Unknowable,' but he has not (as far as I recollect) explained to us as yet the full and exact nature and tenets of that religion the ritual of which is thus hinted at. $\mathrm{Mr}$. Darwin's conception of religion is, however, sufficiently definite. He tells us ${ }^{1}$ that it consists ' of love, complete submission to an exalted and mysterious superior, a strong sense of dependence, fear, reverence, gratitude, hope for the future, and perhaps other elements.'

Let us apply this to the Unknown and the Unknowable. 'Love' for that of which we can by no possibility know anything whatever, and to which we may as reasonably attribute hideousness and all vileness, as beauty and goodness! 'Dependence' on that of which treachery and mendacity may be as much characteristics as are faithfulness and truth! 'Reverence' for an entity, whose qualities, if any, may resemble as much all we despise as all we esteem, and which, for all we know, may be indebted to our faculties for any recognition of its existence at all! 'Gratitude' to that which we have not the faintest reason to suppose ever willingly did anything for us, or ever will! 'Hope' in what we have no right whatever to believe may not, with equal justice, be a legitimate cause for despair as pitiless, inexorable, and unfeeling, if capable of any sort of intelligence whatever !

This is no exaggeration. Every word here put down is strictly accurate, for if that which underlies all things is to us 
the unknowable, then there can be no reason to predicate of it any one character rather than its opposite. If, on the other hand, we have any reason to predicate goodness rather than malice, nobility rather than vileness, then let preachers of the unknowable abandon their unmeaning jargon, for it is no longer with the unknowable we have to deal, and we are plunged at once into a whole world of as distinctly dogmatic theology as can be conceived-a theology the dogmas of which are profoundly mysterious, while they are even more trying, and at the same time more illuminating, to the reason than any others of the whole catena which logically follow.

Although I have taken up this broad ground in controversy, and only contended for truths common to all believers in revelation, nevertheless I would not have it supposed that I in any way shrink from openly avowing my position as a Catholic Christian, and I cannot consider it other than a compliment to my creed that Professor Huxley, in his attack on Christianity generally, singles it out for his special hostility. All Christians owe a debt of gratitude to Professor Huxley for calling forth more clearly the certainty that their religion has nothing to fear from the doctrine of Evolution. It is, however, Catholic Christians who are pre-eminently beholden to him for occasioning a fresh demonstration of the wonderful way in which their greatest teachers of bygone centuries, though imbued with the notions and possessing only the rudimentary physical knowledge of their day, have yet been led to emit fruitful principles by which the Church is prepared to assimilate and harmonise even the most advanced teachings of physical science.

Professor Huxley indulges in rhetorical declamation as to a 'blind acceptance of authority,' but such acceptance is as much repudiated by me as by P'rofessor Huxley. The Church in addressing unbelievers appeals to 'reason' and 'conscience' alone for the establishment of that Theistic foundation on 
which she reposes, and no acceptance of authority can be called 'blind' which results from a clear perception both of its rational foundation and of the harmony of its dogmas and precepts with those highest faculties of our nature, reason and conscience.

I confess myself weary of these tedious declamations as to the incompatability of science with Christianity on the one side, as also of timid deprecations on the other. The true position of these two powers justifies neither such hopes nor such fears; for, in truth, no possible development of physical science (and as to Biology I claim to speak with some slight knowledge) can conflict with Christian dogma, and therefore every attempt to attack it from that basis is necessarily rutile.

On the other hand, so far from the Christian religion tending to cramp or fetter intellectual development, it is notorious that some of the profoundest thinkers of recent, as of more ancient times, have been believers in Christianity, and I am convinced that every man who rejects that belief is ipso facto necessarily condemned not only to a moral but also, and as inevitably, to an intellectual inferiority as compared with what he might attain did he accept that system in its fulness. The Christian creed has long been before the world. I would invite Professor Huxley to formulate his system in distinct propositions, that it also may be tested by our supreme and ultimate standards - 'reason' and 'conscience.'

With the extreme hatred of Catholicity which animates my critic, it is easy to understand the irritation which my demonstration of the harmony which exists between the Church and modern science has caused him. He lets it be seen that he had supposed science to have thoroughly refuted some of the Church's fundamental dogmas, hence the vehement reproaches I have unwittingly drawn down upon my head by my endeavour to promote concord. I feel 
persuaded, however, that an intolerance which would exclude from the band of 'loyal soldiers of science' a Secchi, a Van Beneden, and a Sullivan, merely because they happen to be at the same time 'true sons of the Church,' will not commend itself to the great bulk of my scientific fellow-countrymen any more than the wish to deprive Catholics of their common rights as citizens will be approved of by the English-speaking races generally.

Turning to Professor Huxley's observations in another branch of philosophy, I proceed now to say a few words as to his strictures on the psychology of the Quarterly Reviewer.

I apprehend that my critic's psychological views coincide in the main with those of Mr. Herbert Spencer. Now it is not of course possible within the limits of this article to write a treatise on psychology, and nothing less would be requisite to explain the grounds of my complete and fundamental divergence from the views referred to. It must suffice to say here, that Professor Huxley has adduced no argument and has brought forward no kind of illustration which I have not maturely considered and deliberately rejected as inadequate and fallacious. Another time I hope to be able to go at length into this question and to endeavour to explain, according to the system I adopt, the facts adduced by the opposite school; as also to support my views by positive arguments. In the meantime I heartily re-echo Professor Huxley's tribute to the supreme importance of 'the philosophical questions which underlie all physical science,' and I am confident that vast good would result if only men could be brought to undergo the labour and persevering application necessary for their thorough investigation.

I must here, then, confine myself to the clearing up of some misapprehensions and misrepresentations.

In the first place, Professor Huxley objects to the assertion that 'sensation' is not 'thought,' 'though sensations 
supply the conditions for the existence of thought.' $\mathrm{He}$ says :-

'If I recall the impression made by a colour or an odour, and distinctly remember blueness and muskiness, I may say with perfect propriety that I 'think of ' blue or musk ; and so long as the thought lasts, it is simply a faint reproduction of the state of consciousness to which I gave the name in question, when it first became known to me as a sensation.

'Now, if that faint reproduction of a sensation, which we call the memory of it, is properly termed a thought, it seems to me to be a somewhat forced proceeding to draw a hard-and-fast line of demarcation between thoughts and sensations. If sensations are not rudimentary thoughts, it may be said that some thoughts are rudimentary sensations. No amount of sound constitutes an echo, but for all that no one would pretend that an echo is something of totally different nature from sound.'

To this I can now only reply by observing that according to my view a recalled thought is not a 'rudimentary sensation,' though the sensible memory is made use of with regard to it. I also deny utterly that the faint recurrence of a sensation can ever be properly termed a thought, and the act of 'recalling' such sensation is only to be so named on account not of the sensation recalled, but of the intellectual, voluntary act of recalling.

The analogy of an echo is false and misleading. An echo is merely a particular kind of sound, but a thought is not merely a particular kind of sensation.

Again, Professor Huxley objects to the assertion that sensations supply the conditions for the existence of thought or knowledge-saying :-

'If this implies that sensations supply the conditions for the existence of our memory of sensations, or of our thoughts about sensations, it is a truism which it is hardly worth while to state so solemnly. If it implies that sensations supply anything else it is obviously erroneous. And if it means, as the context would seem to show it does, that sensations are the subject-matter of all thought 


\section{Evolution and its Consequences}

or knowledge, then it is no less contrary to fact, inasmuch as our emotions, which constitute a large part of the subject-matter of our thought or of knowledge, are not sensations.'

It seems to me that this argument is quite unfair, and that it is a false dilemma. The Reviewer's words evidently point to 'sensations' as the condition of our knowledge of external objects, and this, at least, is no truism. For my part, if I understand Professor Huxley rightly, I should assert that to be 'axiomatic' which he says is 'obviously erroneous.'

The short summary in the Quarterly Review of the physical characters common to man and brutes on the one hand, and peculiar to man as a rational animal on the other, was evidently not intended as an exhaustive catalogue, but merely as a concise statement of certain leading and essential differences. Therefore 'emotion,' as avowedly common to man and brute, and volition and memory, as beside the question, were reasonably left unnoticed.

A carping criticism as to the word 'agency' as applied to sensation in these reflex acts in which sensation intervenes, is what, I confess, I should not have expected from Professor Huxley. He certainly would never think of denying the intervention of sensation in such acts.

As to his assertion that the Quarterly Reviewer in conceding to animals his first four groups of actions, 'grants all that is necessary for the purposes' of his critic, it is an error which arises from the thorough misapprehension by Professor Huxley of the Reviewer's position, as will be made manifest by what I have to say concerning reason and predication.

Professor Huxley gives us, in illustration of his views, a comparison between a gamekeeper and a greyhound, both engaged in coursing, the relevancy of which, I confess, escapes me.

No one denies that man is an animal. No one denies 
that the sensitive faculties of the greyhound are possessed by the man, just as are his digestive and locomotive faculties. No anatomist denies that man's bodily structure closely resembles the brutes', and I, at least, have been forward in asserting it. I maintain, however, that though man and dog agree in exhibiting the phenomena of feeling, they differ altogether as to the phenomena of thinking, of which man alone gives any evidence.

Professor Huxley asks a singular question. $\mathrm{He}$ says, 'What is the value of the evidence which leads one to believe that one's fellow-man feels? The only evidence in this argument of analogy is the similarity of his structure and of his actions to one's own.' Surely it is not by similarity of actions in any ordinary sense of the word, but by language that men are placed in communication with one another, and that the rational intellect of each perceives the rationality and sensibility of his fellow-man.

Professor Huxley asserts that by 'a combination of sensible images' the Quarterly Reviewer must mean more than his words imply, or otherwise a greyhound would not run after a hare. Certainly the Reviewer could hardly have suspected that any one would take him to mean that brutes are destitute of appetites and emotions. The conjunction, however, of these appetites and emotions with sensible images in complex associations is certainly amply sufficient to explain all that is exhibited by dogs in 'the noble art of coursing,' and this Professor Huxley must allow if, as I suspect, he would attribute nothing essentially higher to the gamekeeper himself.

On the question concerning morality I have, I conceive, some reason tô complain of Professor Huxley's treatment of my observations. From the remarks which he has again and again made, it is evident to whom he attributes the article in the Quarterly Review. Nevertheless, he, in the first place 
misrepresents my statement in my book, and attributes to me an absurdity which is not in it, but which is distinctly pointed out and repudiated in the Quarterly Review. In the second place, he accuses me of neglecting a remark made by Mr. Darwin, which remark is not only referred to, but actually quoted in the same review.

First, with regard to Mr. Darwin. In this matter Professor Huxley accuses me of charging that gentleman 'with being ignorant of the distinction between material and formal goodness,' though Mr. Darwin himself 'discusses the very question at issue in a passage well worth reading, and also comes to a conclusion opposed to Mr. Mivart's axiom.' As I have said, this passage is not only referred to but actually quoted in the Quarterly Review. In that passage, however, Mr. Darwin, though he notices, gives no evidence of fully understanding my distinction, nor, though he notices an objection, does he meet the difficulty in the least. Professor Huxley seems to think that because Mr. Darwin has referred to an objection, that that objection has thereby lost its force. The objection, however, has not been refuted either by Mr. Darwin or Professor Huxley, and hence it becomes probable that, as I am convinced is the case, it cannot be refuted.

We will turn now to the more serious misrepresentation of which I have to complain. My critic exhibits me as committing the absurdity of maintaining that no act can be 'good' unless it is done with deliberate and actual advertence in every instance-as if I thought that a man must stand still, consider and reflect in each case in order to perform a meritorious action. He also implies that I am so unreasonable as to deny 'merit' to actions done unreflectingly and spontaneously from the love of God or one's neighbour.

What I assert, however, is, that for an act to be 'good' it must be really directed by the doer to a good end, either actually or virtually. The idea of good, which he has in the 
past apprehended, must be influencing the man at the time, whether he adverts to it or not, otherwise the action is not moral. The merit of that virtue, which shows itself even in the spontaneous, indeliberate actions of a good man, results from the fact of previous acts having been consciously directed to goodness, by which a habit has been formed. The more thoroughly a man is possessed by the idea of goodness the more his whole being is saturated with that idea, the more will goodness show itself in all his even spontaneous actions, which thus will have additional merit through their very spontaneity. Now this was actually expressed in the Quarterly Review, ${ }^{1}$ where of such an act it is stated that 'it is moral as the continuation of those preceding deliberate acts through which the good habit was originally formed; and the rapidity with which the will is directed in the case supposed may indicate the number and constancy of antecedent meritorious volitions.'

Not only, however, does Professor Huxley avoid noticing this passage, but he quotes my words as to the unmeritorious nature of actions ' unaccompanied by mental acts of conscious will directed towards the fulfilment of duty,' so as to lead his readers to believe that I say this absolutely. He takes care not to let them know that here I am speaking ${ }^{2}$ only of the 'actions of brutes such as those of the bee, the ant or the beaver,' which, of course, never at any period of the lives of any one of these creatures were consciously directed to 'goodness' or 'duty' as an end, so that no later spontaneous actions could in their case result from an acquired habit of virtue, on which account I was fully justified in speaking of their actions as devoid of morality.

Professor Huxley speaks of 'the most beautiful character to which humanity can attain, that of the man who does good without thinking about it' (p. 468). Does he mean

${ }^{1}$ See ante, p. 49.

2 See Genesis of Species, p. 221, 2nd edition. 
that the absence of thought is the cause of the beauty? If so, then if I do the most beneficial acts in my sleep, I attain this apex of moral beauty. This, of course, he will not allow. Therefore it is not by reason of the not thinking about it that the action is beautiful, but, as Professor Huxley goes on to say, 'because he loves justice and is repelled by evil.' In this last, then-in this habit of mind, the beauty consists. But will the Professor say that the man got himself into this state without previous acts of conscious will? Can a man elect for justice without being able to distinguish between the just and unjust? If he loves moral beauty, must he not know it?

Professor Huxley does not, I believe, mean what he says when he asserts that acts may be moral which are not directed to a good end. Were it so, such words as 'virtue' and 'goodness' would have no rational and logical place in his vocabulary.

Similarly, I do not believe him when he says he 'utterly rejects' the distinction between ' material' and 'formal ' morality. ${ }^{1}$ I do not, because he has elsewhere asserted that 'our volition counts for something as a condition of the course of events.' If, however, he rejects the distinction he says he rejects, he thereby absolutely denies every element of freedom and spontaneity to the human will, and reduces our volition to a rank in the 'course of events,' which counts for no more than the freedom of a match as to ignition, when placed within the flame of a candle. With the enunciation of this view, 'formal morality' most certainly falls, and together with it every word denoting 'virtue,' which thus becomes a superflous synonym for pleasure and expediency.

Adverting now to the question of 'reason,' according to Professor Huxley (p. 463), 'ratiocination is resolvable into predication, and predication consists in marking, in some way,

1 See ante, vol. i. p. 328.

VOL. II. 
the succession, the likeness and unlikeness, of things or their ideas. Whatever does this, reasons; and if a machine produces these effects of reason, I see no more ground for denying to it the reasoning power, because it is unconscious, than I see for refusing to Mr. Babbage's engine the title of a calculating machine on the same grounds.'

'Thus it seems to me that a gamekeeper reasons whether he is conscious or unconscious, whether his reasoning is carried on by neurosis alone, or whether it involves more or less psychosis.'

According to my idea of the matter, predication essentially consists not in marking 'succession, likenesses and unlikenesses,' but in recognising these relations as true.

To this extent I may shelter myself under the authority of Mr. John Stuart Mill. Mr. Mill, in criticising Sir William Hamilton's definition of judgment, makes the following remarks (Examination of Sir William Hamilton's Philosophy, p. 346):-

'The first objection which, I think, must occur to any one, on the contemplation of this definition, is that it omits the main and characteristic element of a judgment and of a proposition. . . . When we judge or assert, there is introduced a new element, that of objective reality, and a new mental fact, belief. Our judgments, and the assertions which express them, do not enunciate our mere mode of mentally conceiving things, but our conviction or persuasion that the facts are conceived actually exist; and a theory of judgments and propositions which does not take account of this, cannot be $a$ true theory. In the words of Reid "I give the name of judgment to every determination of the mind concerning what is true or what is false. This, I think, is what logicians, from the days of Aristotle, have called judgment." And this is the very element which Sir William Hamilton's definition' [and I may now add Professor Huxley's also] 'omits from it.'

Further on Mr. Mill says :- 1

'Belief is an essential element in a judgment. . . . The recognition

1 As before quoted. See ante, vol. i. p. 405. 
of it as true is not only an essential part, but the essential element of it as a judgment; leave that out, and there remains a mere play of thought, in which no judgment is passed. It is impossible to separate the idea of judgment from the idea of the truth of a judgment; for every judgment consists in judging something to be true. The element belief, instead of being an accident which can be passed in silence, and admitted only by implication, constitutes the very difference between a judgment and any other intellectual fact, and it is contrary to all the laws of definition to define judgment by anything else. The very meaning of a judgment or a proposition is something which is capable of being believed or disbelieved; which can be true or false; to which it is possible to say yes or no.'

In addition to this, Mr. Mill, in his notes on his father's, Mr. James Mill's, Analysis of the Human Mind, ably shows, against Mr. Herbert Spencer, that rational belief cannot be explained as being identical with indissoluble association (vol. i. p. 402).

In denying, then, reason to brutes-in denying that their acts are rational, I do not, of course, deny for a moment that they are rational in the sense in which Mr. Babbage's machine is calculating, but what I do maintain is, that brutes have not the power of forming judgments in the sense above explained. And I still more emphatically deny that brutes have any, even the very dimmest, consciousness of such ideas as 'ought' and moral excellence. And because I further believe that no amount of sensible experiences can generate these conceptions, I deny that any brute is even potentially a moral agent. Those who credit brutes with 'morality,' do so by first eliminating from that idea all its essential characteristics.

One word now of explanation. Professor Huxley seems much disturbed at my speaking of virtue as, in his view, $a$ kind of retrieving, ${ }^{1}$ and accuses me of imposing an 'injurious

${ }^{1}$ See ante, vol._. $. " p . ~ 326$, and also my Genesis of Species, 2nd ed., pp. 213 and 232. 
nickname,' and making a 'joke.' Nothing could have been further from my intention than either one or the other. As it happens the expression was not my own, but was picked up in conversation with as thorough a Darwinian even as Professor Huxley himself, who used it, as I understood, not as a nickname, but as a handy mode of bringing home his conceptions to my mind. I made use of it in all innocence, and I still think it singularly apt and appropriate, not certainly to express the conception of virtue, but to bring home the utilitarian notion of it. Professor Huxley says, 'What if it is? Does that make it less virtue?' I answer, unhesitatingly, that it not only makes it 'less virtue,' but prevents it being virtue at all, unless it springs as a habit acquired from self-conscious acts directed towards an end recognised as good.

Professor Huxley regrets that I should 'eke out' my arguments against the views he patronises, by ascribing to them 'logical consequences which have been over and over again proved not to flow from them.' But it was to be expected that a disciple of Mill, ${ }^{1}$ such as Professor Huxley; would know that in matters of this kind it is impossible to reason $\alpha$ posteriori, on account of the complexity of the conditions; and that the à priori argument, by deductions

${ }^{1}$ In speaking of the application of the experimental method to social science, Mr. Mill remarks :- 'This mode of thinking is not only general with practitioners in politics, and with that very numerous class who (on a subject which no one, however ignorant, thinks himself incompetent to discuss) profess to guide themselves by common sense rather than by science; but is often countenanced by persons with greater pretensions to instruction. . . . . As, however, the notion of applicability of experimental methods to political philosophy cannot co-exist with any just conception of these methods themselves, the kind of arguments from experience which the chemical theory brings forth as its fruits (and which form the staple, in this country especially, of parliamentary and hustings oratory) are such as, at no time since Bacon, would have been admitted to be valid in chemistry itself, or in any other branch of experimental science.' (Mill's Logic, vol. ii. p. 454.) 'It is evident that Sociology, considered as a system of deductions a priori, cannot be a science of positive predictions, but only of tendencies.' (Op. cit. p. 477.) 
from inevitable tendencies, can be alone employed. If Professor Huxley is persuaded of the evil consequences of Christianity, I am equally persuaded of the evil consequences of his system.

No one, I believe, has a greater regard for Professor Huxley than I have, and no one is more convinced than I am of the uprightness of his intentions and his hearty sympathy with self-denying virtue. Nevertheless, the principles he unhappily advocates cannot but tend, by a fatal necessity, in one direction, and to produce results socially, politically, and morally, which he would be the first to deplore. They tend in the intellectual order to the degradation of the mind, by the essential identification of thought with sensation, and in the political order to the evolution of horrors worse than those of the Parisian Commune. I refrain from characterising their tendency in the moral order.

Before concluding, I must make one observation with regard to Mr. Wallace. I emphatically disclaim having had any intention of depreciating obliquely Mr. Darwin, though I desired to do justice to Mr. Wallace. It is an undoubted fact that there are many men who, if they had thought out natural selection simultaneously with Mr. Darwin, would have clamorously sought a recognition of the fact, and have lost no opportunity of asserting simultaneity. No one can affirm that Mr. Wallace has shown the faintest inclination of the kind, while no one can deny that if he had followed the clamorous path, his name would have been more widely known and more popularly associated with natural selection than has been, in fact, the case.

It is a gratuitous assertion on the part of Professor Huxley to say I have suggested that Mr. Darwin's eminence is due to Mr. Wallace's modesty, in any other sense than what I have now explained-namely, that had Mr. Wallace put himself more prominently forward, he would have been 
seen more distinctly by the popular eye, an assertion no one - can question. ${ }^{1}$.

As a fact, I believe that $\mathrm{Mr}$. Wallace, in the passage quoted by Professor Huxley, allows his modesty to deceive him. From what I know of Mr. Wallace, I venture to affirm he underrates his powers, and I am convinced he could have written as good a defence of natural selection as even the Origin of Species. There are not wanting those who, though they have carefully studied Mr. Darwin's work, only fully understood his theory when presented to their mind in the clear, lucid, and admirable writings of $\mathrm{Mr}$ Wallace.

1 Dr. Hooker, in his address to the British Association at Norwich, made the following remarks on the subject: 'Of Mr. Wallace and his many contributions to philosophical biology, it is not easy to speak without enthusiasm; for, putting aside their great merits, he, throughout his writings, with a modesty as rare as I believe it to be in him unconscious, forgets his own unquestioned claims to the honour of having originated, independently of Mr. Darwin, the theories which he so ably defends.'-See Report for 1868, p. Ixxi. 


\section{SPECIFIC GENESIS.}

To the Editor of the 'North American Review':-

SiR,-The rapid growth of physical science, and the constant publication of ever-new observations, make such demands on the time of naturalists that an author actively engaged upon a subject covering the whole field of biology cannot be expected to reply directly to critics, unless under very exceptional circumstances.

I have to thank Mr. Chauncey Wright for having been so obliging as to devote much space, and necessarily a considerable portion of his valuable time, to an examination of my recent work, the Genesis of Species. Nevertheless I must confess that, with all respect for his conspicuous talents and for his deserved reputation, I should not have undertaken the following few words of explanation but for his paper's wide circulation in England and elsewhere by Mr. Darwin.

Any criticism published by Mr. Darwin himself, or by Professor Huxley, I should always deem it a duty carefully to consider and, if possible, reply to; and the very extensive circulation by Mr. Darwin of a reprint of Mr. Chauncey Wright's remarks, appears to me to amount to such an implied adoption of them, as to demand for them a consideration somewhat similar to that which I should accord them were Mr. Darwin himself their author.

Mr. Wright's criticism touches upon so many matters of detail that it is not altogether easy to ascertain his main 
objects. Having, however, considered his remarks with that care which my esteem for his opinions makes incumbent on me, I venture to express my belief that, neglecting minor matters, his criticism is mainly directed to the assertion of two points.

One of these is, that I have misrepresented Mr. Darwin's views, and have been guilty of involuntary injustice with respect to the natural forces which, according to that naturalist, have determined specific forms.

The other is, that I have attributed an irreligious tendency to Mr. Darwin's writings which they do not, in fact, possess; and that this is in part owing to my defective knowledge, in part to early prejudices.

Thus Mr. Wright speaks of my 'theological education' and my 'schooling against Democritus.' It is a matter of wonder to me who could have so misled Mr. Wright. Though reluctant, in the extreme, to obtrude such private and personal matters before the public, I must nevertheless, in justice, observe, that my schooling has been of the very opposite character, and perfectly in unison with that which Mr. Darwin himself would favour. Only at length, and with difficulty, have I struggled out of that philosophy of 'nescience,' the evils and the fallacies of which are so apparent to me because, at one time, its doctrines so completely possessed my assent.

With regard to Mr. Darwin's theory of the origin of species, I should hasten eagerly to acknowledge my error if I had been guilty of injustice with respect to it, and also to thank any critic who had been so kind as to call my attention to such unintentional unfairness. I must confess, however, that I cannot detect that misrepresentation in my Genesis of Species which Mr. Wright seems to there discover.

In common with so many others I was, at one time, a hearty and thoroughgoing disciple of $\mathrm{Mr}$. Darwin, and I 
accepted from him the view that Natural Selection was 'the origin of species.' It was only by degrees, and through the evidence of a multitude of biological facts, that an opposite conclusion was gradually forced upon me. Having come to that conclusion, on scientific grounds only, after careful reconsideration of those grounds and much discussion of the subject, I ventured to publish my Genesis of Species. Therein I endeavoured to bring before the public the leading facts which had produced the conviction in my own mind that Natural Selection was not the origin of species, not the main determining agent in the fixation of specific characters; although I allowed that it played, and necessarily must play, a certain subordinate part.

This conviction had forced itself on many minds before the publication of my book, and since then has approved itself to the minds of many more. Indeed, Mr. Darwin himself seems to have come round substantially, though not avowedly, to the same opinion, and has, in his Descent of Man, implicitly admitted, though he has not yet explicitly declared, that Natural Selection is not the origin of species. I cannot but confess that it appears to me even Mr. Chauncey Wright himself concedes all that for which I contend, though he at the same time seems to imagine that he asserts the validity of Mr. Darwin's original position.

No one could be less disposed than I am to detract from the great merit unquestionably due to Mr. Darwin, or to ignore the vast impetus which his views have given to the wide reception of the doctrine of evolution. Nevertheless, we must not allow our just admiration for the zeal, genius, and courage of Mr. Darwin to blind our eyes to two facts. One of these is that an important part of Mr. Darwin's theory was not new, but, on the contrary, very old. The other is, that though the popular acceptance of evolution has been brought about through him, yet that the minds of scientific men were 
well prepared for, and well disposed towards, evolution years before the appearance of The Origin of Species.

Biological facts, by their gradual accumulation, had long been predisposing scientific minds to the acceptance of this theory. I myself, indeed, fully accepted it, and I found that a similar acceptance existed in the minds of others, notably in that of Professor Owen. Mr. Wright, therefore, is certainly correct, in this sense, when he says that 'it is not to what is now known as "Darwinism" that the prevalence of the doctrine of evolution is to be attributed or indirectly assigned.' The part of Mr. Darwin's theory which is old is that which attributes so much importance to the destructive powers of nature, a view advocated by Lucretius and treated of by Aristotle in the passage quoted in my book.

What, however, was unquestionably Mr. Darwin's own, was the remarkable conception that this exterminating power, acting upon organisms presenting slight variations, so overbore all other influences as to occasion the survival of the fittest variations, and in this way (by a process of cutting off and limiting) fixed the characters of the different organic species, thus becoming their origin. The origin, not, of course, of the slight variations, but of the fixing of these in definite lines and grooves.

Gradually, however, the arguments of opponents have forced upon Mr. Darwin's active and candid mind modifications of his views, till, as I have said, he has come to admit in principle that Natural Selection is not the origin of species. I cannot myself see that there is, in this change of view, anything at all derogatory to $\mathrm{Mr}$. Darwin; and for my part, my esteem for that illustrious naturalist is strengthened rather than weakened when I read candid admissions of antecedent error. These admissions should not be brought forward, save when an unscientific appeal is made to his authority, or when an advocate more zealous than judi- 
cious attempts to deny that Mr. Darwin's opinions have undergone any grave modifications. Then indeed truth and justice demand the production of such admissions. They do so since the assignment of the law of Natural Selection to a subordinate place is manifestly an abandonment of the Darwinian theory as originally proposed; for how can that be said to be the origin of species which only co-operates, in an inferior and comparatively uninfluential manner, in determining that origin?

Mr. Chauncey Wright's remarks seem to me, then, to render necessary a reference to these earlier statements of $\mathrm{Mr}$. Darwin. A number of such statements ${ }^{1}$ and admissions of our great naturalist-not, indeed, his earliest, but from his Descent of Man and the third edition of The Origin of Species-were recently brought forward in the July number of the Quarterly Review. ${ }^{2}$ They were published in that periodical for the purpose of guarding the public from a hasty acceptance of Mr. Darwin's dogmatic expressions, merely in deference to his authority, and without a careful estimate of the value of the facts brought forward by him.

The passages referred to seemed to me to contain statements amply sufficient to repel $\mathrm{Mr}$. Wright's charge against me of injustice to Mr. Darwin, and to show, on the one hand, that the original theory of the origin of species was such as I have represented it to have been; and, on the other, that Mr. Darwin has, in fact, abandoned the position which he originally took up.

From the passages referred to we may learn that Mr. Darwin, even so lately as in his third edition of the Origin, considered that Natural Selection acts only by numerous

1 They are to be found in The Origin of Species, 3rd edition, pp. 208, 214, 220, 223 ; 5th edition, p. 104. The Descent of Man, vol. i. pp. 125, 152, 154, 223 ; vol. ii. pp. $176,198,387$, and the postscript at the beginning of the volume. Animals and Plants under Domestication, vol. ii. p. 57.

2 See ante, pp. 5-7. 
slight modifications of special use to the organisms possessing them. In fact, that he completely stakes the whole of his theory on the non-existence or non-action of causes of any moment other than Natural Selection; it being the essence of that theory to recognise only the conservation of slight variations directly beneficial to the creature which possesses them, by affording it better means either of obtaining nourishment or of eluding or outstripping its enemies or of reproducing its kind.

From The Descent of Man, however, we find that Mr. Darwin now recognises and admits ${ }^{1}$ that he has fallen into various errors.

Every respect and deference ought to be shown to a naturalist such as Mr. Darwin, but deference has its limits and must not be exercised to the sacrifice of truth, and truth compels the recognition of the important modifications above noticed. It is not only, however, critics that dissent from Mr. Darwin's views who recognise the existence of these changes. Mr. Darwin's authorised interpreter, Professor Huxley, has lately told us the highly significant fact that $\mathrm{Mr}$. Darwin is even inclined to reply in the affirmative to the question whether a variety 'can be perpetuated, or even intensified, when selective conditions are indifferent, or perhaps unfavourable to its existence.' A more complete repudiation in principle of the origin of species by Natural Selection it would be difficult if not impossible to imagine.

Mr. Darwin has not, however, so far as I know, explicitly declared what Professor Huxley tells us he is inclined to admit. He has certainly made many important and significant admissions, but there is one more which consistency seems to demand as the logical outcome of others above cited: I mean the admission that the attribution to Natural Selection of the main determining office in the fixation of specific

${ }^{1}$ See ante, p. 7. 
characters has also been 'a serious error,' whether it be not rather a fortunate than an 'unfortunate' one.

Mr. Wright challenges the production of a sudden adaptive modification of a race, wild or domesticated, 'not referable by known physiological laws to the past history of the race on the theory of evolution.' In this statement I must in the first place object to the introduction of the words 'on the theory of evolution,' as that theory, far from being opposed, is, on the contrary, adopted and contended for by me, and I do not understand how Mr. Wright can have inserted them unless by inadvertance. Instances, however, of modifications, the production of which he desiderates, can readily be supplied. Thus the Cashmere sheep, when transferred to Europe, lost their long wool in a few generations, and this could not possibly have been due to Natural Selection. Again, the marine animals now living in Swedish lakes have become remarkably transformed, and the instance noticed by $\mathrm{Mr}$. Darwin as to the Mediterranean oyster, though not evidently adaptive, is probably so, and if so would be in point. There was, however, no need to bring such cases forward, for surely it was fair to take Mr. Darwin's own estimate of what facts he would consider fatal, and such facts I claim to have brought forward, in sufficient number, in my book. I can only express my profound regret that I should be so unfortunate as to seem to Mr. Chauncey Wright to have made an 'unfathomable translation' of the theory of Natural Selection. Mr. Darwin nowhere himself says, with Mr. Wright, that the 'slightness' of the variations he speaks of 'is only relative to the differences between the characters of the species'; and I cannot but think Mr. Wright himself misconceives Mr. Darwin's meaning, for I believe the latter gentleman would not speak of the sudden development of a large proboscis, like that of semnopithecus nasalis, as a 'slight' variation. 
An admission which Mr. Darwin makes, and which I considered and consider to be important, is sought to be explained away by Mr. Chauncey Wright in a mode I cannot think admissible. He tells us that when $\mathrm{Mr}$. Darwin says that the goose 'seems to have a singularly inflexible organisation,' $\mathrm{Mr}$. Darwin's 'obvious meaning' is 'that the goose has been much less changed by domestication than other domestic birds.' Certainly if Mr. Darwin had meant this, he would not have used the word 'inflexible,' but 'unmodified,' or some equivalent expression. To have a 'singularly inflexible organisation' is to have one which cannot without great difficulty be modified, not one which, as a fact, has not been modified.

Similarly where Mr. Darwin speaks of ' a whole organism having become plastic and tending to depart from the parental type,' Mr. Wright asserts that Mr. Darwin means 'capable of being moulded or fashioned to the purpose, as clay.' This is to credit Mr. Darwin with the enunciation of a truism which I am sure he would never have written. The words 'tends to depart '1 are plainly a repetition and explanation of the epithet 'plastic,' and fix its meaning. Mr. Darwin here evidently predicates an existing predisposition, and not a mere state of indifference. By 'tends to depart' he cannot mean 'capable of being made to depart, for that would not indicate any influence which has affected the 'whole organisation,' as by his hypothesis every organism is 'capable' of being modified.

I will now turn to the second matter of argument, that in which Mr. Chauncey Wright treats of the alleged possibly irreligious tendencies of Mr. Darwin's theory, and of my incompetency in physics and ignorance of the experimental philosophy.

1 The omission of the words 'in a slight degree' in my book was purely accidental. As, however, the question is one of principle, I do not see that the omission was of any importance. 
He says :-

'Mr. Mivart has made the mistake, which nullifies nearly the whole of his criticism, of supposing that "the theory of Natural Selection may (though it need not) be taken in such a way as to lead men to regard the present organic world as formed, so to speak, accidentally, beautiful and wonderful as is confessedly the haphazard result" (p. 33). Mr. Mivart, like many another writer, seems to forget the age of the world in which he lives and for which he writes, -the age of "experimental philosophy," the very standpoint of which, its fundamental assumption, is the universality of physical causation. This is so familiar to minds bred in physical studies, that they rarely imagine that they may be mistaken for disciples of Democritus, or for believers in "the fortuitous concourse of atoms," in the sense, at least, which theology has attached to the phrase.'

I feel a little difficulty in replying to this criticism, because I cannot bring myself to attribute to $\mathrm{Mr}$. Wright such a misapprehension either of my meaning or of that of the school of Democritus, as seems necessary to explain it.

I would willingly suppose that an obscurity of expression on my part is alone to blame, but in using the word 'accidentally' I qualified it by the prefix 'so to speak.' But even had I not done so, I could not have imagined that any one would think me unaware that the various phenomena which we observe in nature have their respective phenomenal antecedents. It is extremely difficult to me to think that $\mathrm{Mr}$. Wright can suppose I held the opinion that the phenomena of variation, etc., are not determined by definite physical antecedents. Yet, if he does not so suppose, how can he assert that when I use the expression 'accidentally' I mean anything antagonistic to physical causation?

On the other hand, Mr. Wright cannot suppose that the old atheistic philosophy held events to be accidental in the strict sense, for he knows very well that Democritus and Empedocles and their school no more held phenomena to be undetermined or unpreceded by other phenomena, than do their successors at the present day. 
My meaning, which I rashly imagined plain enough, was that Mr. Darwin's theory might be so taken as to oppose the conception of design in the same way as the old Ionian theory opposed that conception. That I was fully justified in expressing such an opinion is, I conceive, plain, from the language employed by Mr. Darwin himself. In his work on Animals and Plants under Domestication, Mr. Darwin considers the building of an edifice from broken fragments of rock, and makes use even of strong expressions of the kind referred to. He says :-

'In regard to the use to which the fragments may be put, their shape may sTRICTLY be said to be accidental. . . . If the various laws which have determined the shape of each fragment were not predetermined for the builder's sake, can it with any greater probability be maintained that $\mathrm{He}$ specially ordained, for the sake of the breeder, each of the innumerable variations in our domestic animals and plants? .... But, if we give up the principle in one case,-if we do not admit that the variations of the primeval dog were intentionally guided, in order that the greyhound, for instance, that perfect image of symmetry and vigour, might be formed-no shadow of reason can be assigned for the belief that the variations, alike in nature, and the result of the same general laws, which have been the groundwork through Natural Selection of the formation of the most perfectly adapted animals in the world, MAN INCLUDED, were intentionally and specially guided. However much we may wish it, we can hardly follow Professor Asa Gray in his belief that "variation has been led along certain beneficial lines," like a stream "along definite and useful lines of irrigation."'

Not only then may the organic world, on the Darwinian theory, be conceived as formed in some sense accidentally, but we have Mr. Darwin's own words for viewing that formation as 'STRICTLY ACCIDENTAL.' I say 'his words,' because I am far from desiring to bind Mr. Darwin in anti-teleological fetters. I have carefully given him credit for every theistic expression I noticed, as it was at once my duty and my pleasure to do. 
Here I take the opportunity of acknowledging, as I have also done in my second edition, that an American naturalist -Professor Theophilus Parsons, of Harvard University_put forth, more than ten years ago, views ${ }^{1}$ very similar to those I enunciated in my Genesis of Species, though they were of course unknown to me when I published my first edition. Mr. Wright, however, is mistaken when he states that I am 'indebted to Mr Galton' for my conception of specific genesis although I made use, with due acknowledgment, of that gentleman's illustration of a conception analogous to mine.

Mr. Wright has been so unfortunate as to misapprehend Mr. Murphy also. Speaking of spheres and crystals, that gentleman is quoted as saying:-

'Attraction, whether gravitative or capillary, produces the spherical form ; the spherical form does not produce attraction.'

Upon this Mr. Wright remarks :-

' No abstraction ever produced any other abstraction, much less a concrete thing. The abstract laws of attraction never produced any body, spherical or polyhedral.'

But really not only has Mr. Murphy not said they did, but his very expression $\mathrm{Mr}$. Wright will, I am sure, regret to see has been changed by my critic; and the result is, that Mr. Murphy is unlucky enough to be blamed for what he never said, or apparently thought of saying. This is all the more hard because Mr. Wright goes on to observe, 'it was actual forces acting in definite ways that made the sphere or crystal,' which is precisely what Mr. Murphy himself said.

Mr. Wright goes on to make a statement which I confess is utterly beyond me. He says :-

'Moreover, in the case of crystals, neither these forces nor the abstract law of their action in producing definite crystals reside in the

${ }^{1}$ See the July number of the American Journal of Science and Art for 1860.

VOL. II. 
finished bodies, but in the properties of the surrounding media, portions of whose constituents are changed into crystals, according to these properties and to other conditioning circumstances.'

If this is so, then when a broken crystal completes itself, the determining forces reside exclusively in the media, and not at all in the crystal with its broken surface! The first atoms of a crystal deposited arrange themselves entirely according to the forces of the surrounding media, and their own properties are utterly without influence or effect in the result !

To my mind, I confess, it would appear manifest that those marvellously delicate and complex ice mosses, which in the winter season occasionally fringe our walls and palings, are not due to forces residing in the atmosphere only, but also in the crystalline particles already deposited and in course of deposition.

Professor Tyndall's teaching differs widely from that of Mr. Chauncey Wright. Speaking of the formation of pyramidal crystals of salt, he says :-

'The scientific idea is that the molecules act upon each other, ... that they attract each other and repel each other at certain definite points or poles, and in certain definite directions, and that the pyramidal form is the result of this play of attraction and repulsion.' 1

Mr. Wright seeks to refute the parallelism asserted by $\mathrm{Mr}$. Murphy and by me to exist between crystals and organisms, saying :-

'In organisms, no doubt, and as we may be readily convinced without resort to analogy, there is a great deal that is really innate, or dependent on actions in the organism, which diversities of external conditions modify very little, or affect at least in a very indeterminate manner, so far as observation has yet ascertained.'

Here Mr. Murphy and I are fortunately at liberty to

${ }^{1}$ Essays on the Use and Limit of the Imagination in Science, 2nd edition, 1871, p. 57. 
invoke in our favour the authority, once more, of Professor Tyndall, who can hardly be deemed even by Mr. Chauncey Wright as incompetent in 'experimental philosophy,' or as likely to forget 'the age of the world in which he lives.' In the little work already quoted ${ }^{1}$ he tells us :-

'This tendency on the part of matter to organise itself, to grow into shape, to assume definite forms in obedience to the definite action of force, is, as I have said, all-pervading. It is in the ground on which you tread, in the water you drink, in the air you breathe. Incipient life, as it were, manifests itself throughout the whole of what we call organic nature.'

Speaking of a living grain of corn, and comparing it with a crystal, he tells us we are bound 'to conclude that the molecules of the corn are self-posited by the forces with which they act upon each other. It would be poor philosophy to invoke an external agent in the one case and to reject it in the other.'

Mr. Wright, however, as I have shown, invokes what is innate in the case of organisms and rejects it in the case of crystals, and asserts that in organisms what is innate is so predominant in its action, that external conditions 'modify' them ' very little.'

Passing over how important an admission this is against any effective action of Natural Selection, let us see how it tells against the analogy maintained.

Is not the innate force, as existing in each organism, that which has been educed by antecedent combinations and conditions, just as much and no more external to it than are the forces of the medium to each atom of a crystal? And how does this tell in the least against the analogy which has been asserted, and which really does exist between each chemical unit and each organic unit? Not of course that it is for a moment contended that there is not, as common observation ${ }^{1} \mathrm{Ibid}$., p. 58. 
tells us there is, a distinct power and principle, 'vitality,' in the one which is wanting in the other, as well as more or less complexity of organisation.

Again we are told, as to organisms: 'External conditions are, nevertheless, essential factors in development, as well as in mere increase of growth. No animal or plant is developed, nor do its developments acquire any growth, without very special external conditions.' Surely, I hardly needed to be solemnly informed of so very elementary a truth.

Regarding the rules of the 'inductive philosophy,' Mr. Wright remarks :-

'A stricter observance of these by Mr. Murphy and our author might have saved them from the mistake we have noticed, and from many others,- the "realism" of ascribing efficacy to an abstraction, making attraction and polarity produce structures and forms, independently of the products and of the concrete matters and forces in them.'

In whom, or in what? and what are attraction and polarity if they be not forces? Who ever considered them as acting independently of themselves? Would Mr. Wright prefer that the earth's orbit should be spoken of not as the resultant of gravity and centrifugal force, but as produced by ' coming together' and 'flying away'? I have, of course, no objection to that mode of expression, but I see no special advantage in it warranting such a departure from usage. It is singular that Mr. Wright himself, on the next page, employs the very 'abstractions' he blames others for making use of. He there quotes approvingly the expressions 'impenetrability,' 'mobility,' and impulsive force of bodies,' and says 'that gravity does really exist and act according to' its laws. It is difficult to see the greater sin in speaking of the 'real existence' of 'polarity' than of 'gravity.' Not only, however, does Mr. Wright quote such expressions, but he uses them himself with the greatest freedom, and without scruple, whenever they suit his purpose. Thus he tells us 
'that variability and selection do really exist and act,' which appear to me quite as much abstractions as polarity or attraction.

Mr. Wright divides ' intellectual genius' into three classes : No. 1, 'that which pursues successfully the researches for unknown causes by the skilful use of hypothesis and experiment'; No. 2, 'that which, avoiding the use of hypothesis and preconceptions altogether, and the delusive influence of names, brings together in clear connection, and contrasts in classification, the objects of nature in their broadest and realist relations of resemblance'; and No. 3, 'that which seeks with success for reasons and authorities in support of cherished convictions.'

I might remark on the purely arbitrary character of this classification. But letting this pass, it must be said that class No. 1 is but a poor monster without No. 2; and that No. 1 is frequently, consciously or unconsciously, also No. 3 ; nor would it be difficult to bring forward an example.

A more real distinction is that to be drawn between the 'scientific' and the 'philosophical' habits of mind, and under these two great genera come subordinate distinctions of different degrees of importance. Now, a naturalist may attain great scientific eminence without being anything of a philosopher, and, similarly, a philosopher need have little acquaintance with physical science; but from the nature of their respective pursuits a different character of mind in each case tends to be developed. It is from this distinction that we find (as we might $\grave{a}$ priori expect to be the case) such breadth of view, freedom of handling, and flexibility of mind on the part of philosophers who are not naturalists, as compared with men great in physical science, who are not at the same time philosophers; a certain rigidity and narrowness seeming to result from the exercise of the mind merely in the arena of physics. 
Passing to details of criticism, Mr. Wright proceeds to consider the question of the giraffe's neck, and I am asked a rather startling question: 'Can Mr. Mivart suppose that, having fairly called in question the importance of the highfeeding use of the giraffe's neck, he has thereby destroyed the utility of the neck altogether, not only to the theory of Natural Selection, but also to the animal itself?' At the first glance this looks as if I had brought myself within the grasp of the Society for the Prevention of Cruelty to Animals. But I may, perhaps, be permitted to ask, in return, Can Mr. Wright suppose that I ever dreamed that the structures of animals are not useful to them, or that my position is an altogether anti-teleological one? Apparently possessed with some such idea, Mr. Wright proceeds to exhibit the giraffe's neck in the character of a 'watch-tower.' But this leaves the question just where it was before. Of course I concede most readily and fully that it is a most admirable watch-tower, as it also is a most admirable high-reaching organ, but this tells us nothing of its origin. In both cases the long neck is most useful when you have got it; but the question is how it arose, and in this species alone. And similar and as convincing arguments could be brought against the watchtower theory of origin as against the high-reaching theory, and not only this, but also against every other theory which could possibly be adduced.

In reply to my objection as to different rates of increase in strength and mass, as the animal increases in size by the supposed transformation, Mr. Wright remarks, that 'the neck may have grown at the expense of the hind parts in the ancestors of the giraffe'; and adds, 'if we met with a man with a longer neck than usual, we should not expect to find him heavier, or relatively weaker, or requiring more food on that account.' I reply, that if we should not do so it would only be from ignorance; for if, ceteris paribus, a man's 
neck was a quarter of an inch longer, he would necessarily and inevitably be heavier, less strong, and requiring more food, minute though the differences in these respects might be.

In considering criticisms on Mr. Darwin's theory drawn from animal structures, we must not forget how very great an advantage Mr. Darwin has. He has devised a theory according to which any possible utility in any organ is enough to account for its formation. It is amazing, then, that anything whatever should be found for which his theory does not readily account. Much wonder and admiration with regard to that theory has been expressed, because of the way it accounts for so many phenomena, forgetting that this is the necessary consequence of the standpoint he has taken up. Let us suppose, for argument's sake, that the theory is utterly wrong; nevertheless, let but the world be preponderatingly governed by intelligence and beneficence, and then the results of that very intelligence and beneficence exhibited in organisms can be made use of to destroy the conception of those qualities in their supreme cause, and to substantiate a theory which, by our supposition, is utterly devoid of truth. It is on this account that Natural Selection can never be completely proved or disproved by physical science in $\grave{a}$ posteriori investigation; for it will be always open to one side to say, the utility not yet shown in any given structure will be shown later, and to the other side to say, whatever utility you show, though existing in an organ, was not the cause of that organ.

This was no doubt felt by the earlier opponents of Mr. Darwin, who naturally opposed him on à priori grounds, and the same feeling has led his supporters to desiderate criticism from the physical-science standpoint, which can never be quite conclusive, and can only be approximatively so by going into great detail. And this, when done, they in turn affect to sneer at as ' minute.' 
Mr. Chauncey Wright's remarks on mimicry do not call for reply, as it is now conceded that imitation occurs where Natural Selection cannot have developed it. In reply to my criticism as to the origin of the mammary gland, my opponent suggests that its development may have been produced by a young mammal's clinging by suction to the body of its dam, this clinging causing sebaceous glands to be hypertrophied, and this hypertrophy causing their secretion to become nutritions. I confess this seems to me an extreme supposition.

With regard to sexual selection, Mr. Chauncey Wright asks, 'Is it credible Mr. Mivart can suppose that the higher or spiritual emotions, like affection, taste, conscience, ever act directly to modify or compete with the more energetic lower impulses, and not rather by forestalling and indirectly regulating them?' I answer unhesitatingly, 'Yes'; and in return say, 'Is it credible Mr. Chauncey Wright can suppose they do not?'

As to apes, it is enough to reply, that other animals are also kept in cages, but do not exhibit the phenomena to which I referred.

Passing to the hoods and rattles of poisonous snakes, Mr. Wright asserts that if "their "warnings" are also used against intended victims, they can only be used either to paralyse them with terror or allure them from curiosity, etc. Has Mr. Wright then never observed the tail of a cat when the animal is watching a mouse?

A somewhat singular exhibition of the use of the imagination occurs where Mr. Wright tells us it may be that 'the rattle will serve all the purposes that drums, trumpets, and gongs do in human warfare. The swaying body and vibrating tongue of most snakes, and the expanding neck, and the hood of the cobra, may serve as banners.' I must submit to be blamed for my 'poverty of resources' by one whose 
'reason' is supplemented by a fancy so active and unrestrained.

In reviewing my chapter on Independent Similarities of Structure, Mr. Wright replies to my remarks as to characters in placental and implacental mammals which are similar, indeed, but not similar through inheritance :-

'Our author ... has incautiously left a hostile force in his rear. $\mathrm{He}$ has claimed in the preceding chapter for Natural Selection that it ought to have produced several independent races of long-necked Ungulates, as well as the giraffe; so that, instead of pursuing his illustrations any further, we may properly demand his surrender.'

But such a demand would be futile; the cases, in fact, being quite dissimilar. With regard to the Ungulates we have the action of similar causes upon organisms which, by the hypothesis, are closely alike; in the case of the carnivorous and insectivorous beasts we have similar causes acting upon organisms which, by the hypothesis, are fundamentally different.

Certainly, then, if Mr. Darwin's theory is true, we ought to have, in the first case, many similar forms developed; and we ought not to have such in the second case. It is just the difference between adding equals to equals and equals to unequals.

Passing over Mr. Chauncey Wright's exposition ${ }^{1}$ of our Lord's discourse to Nicodemus (in which, I fear, few Darwinians will take any interest), I proceed to notice what Mr. Wright exhibits as 'a good illustration' of the origin of species by Natural Selection in the shape of 'the growth of a tree.' It is so, he tells us:-

'For its branches are selected growth, or few out of many thousands that have begun in buds; and this rigorous selection has been.

${ }^{1} \mathrm{Mr}$. Wright speaks of 'the symbols water and the Spirit, which Chris. tians have ever since worshipped.' It is certainly difficult to remember the multitude of sects which have appeared since the dawn of Christianity, but the existence of any body of water-worshippers strikes me as a novelty. 
effected by the accidents that have determined superior relations in surviving growths to their supplies of nutriment in the trunk, and in exposure to light and air. This exposure (as great as is consistent with secure connection with the sources of sap) seems actually to be sought, and the form of the tree to be the result of some foresight in it. But the real seeking process is budding, and the geometrical regularity of the production of buds on twigs has little or nothing to do with the ultimate selected results, the distributions of the branches which are different for each individual tree.'

Now, I willingly accept this illustration, which I propose to turn round and make use of against its author's view, and for the purpose of showing that it exemplifies, not 'the origin of species by Natural Selection,' but the origin of species by innate law, modified by the subordinate action of Natural Selection.

For, in fact, does not every one know that, in spite of these external influences, each kind of tree has a certain general character of growth which is definite and unmistakable. The oak, the fir, the birch, etc., each has its own special facies. Mr. Wright does not deny this; he says :-

'The general resemblance of trees of a given kind depends on no formative principle other than physical and physiological properties in the woody tissue, and is related chiefly to the tenacity, flexibility, and vascularity of this tissue, the degrees of which might almost be inferred from the general form of the tree.'

Precisely so. But on what do these physical and physiological properties depend? It is useless to endeavour to avoid the admission; we shall always be compelled by reason to confess the existence, in each seed, of a principle, an intimius principium conditioning the evolution of the plant according to its nature and laws. To deny that there is a something giving unity to the composite whole, and unity of a definite kind, is to contradict the plain and combined evidence of our senses and our reason.

This internal principle it is which produces the character of 
each tree's growth, while the special details are determined by the action of external influences upon it. Just in the same way, I believe, that an innate predisposing cause produces the evolution of new species; the special details being determined by subordinate agencies, and amongst them that of Natural Selection. Mr. Wright's illustration suits me so well I will pursue it yet further. He observes :-

'If we could study the past and present forms of life, not only in different continents, which we may compare to different individual trees of the same kind, or better, perhaps, to different main branches from the same trunk and roots, but could also study the past and present forms of life in different planets, then diversities in the general outlines would probably be seen similar to those which distinguish different kinds of trees, as the oak, the elm, and the pine; dependent, as in these trees, on differences in the physical and physiological properties of living matters in the different planets,-supposing the planets, of course, to be capable of sustaining life, like the earth, or, at least, to have been so at some period in the history of the solar system.'

Precisely so once more! In each case forms would be evolved in accordance with that innate potentiality which God has implanted in each case in the matter of which such planet was composed. Not that there, any more than here, all that was potential would become actual, but that the innate potentiality, modified by external influences, would be determined in special forms in the production of which the innate power, not the external conditions, would be the main evolving agent.

Mr. Wright seems to consider that the use of such words as 'polarity' and 'luminosity' tends to discourage the investigation of the laws and conditions by and through which such properties are manifested. Mr. Wright tells us, somewhat dogmatically, that 'definite vital aggregations and definite actions of vital forces exist, for the most part, in a world by themselves.' I should be the last to deny the 
distinctness of 'vitality'; but that certain conditions may determine its sudden and definite manifestation, is maintained by his friends as regards the earlier days of this planet. There is one expression of Mr. Wright's which it will be well to notice; he says: 'It is not impossible that vital phenomena themselves include orders of forces as distinct as the lowest vital are from chemical phenomena. May not the contrast of merely vital or vegetative phenomena with those of sensibility be of such order.' I notice with pleasure this hopeful expression. It is most true that there are these differences of order, but there is one more yet. The intellectual or rational order is as distinct from the merely sensible as is the sensible from the vegetative, or this last from the chemical. Here we touch the one great and fatal error of so many of our leading naturalists. The confusion of intellect with sensation, of reason with the association of sensible images, is, I am persuaded, the fundamental speculative vice of the day. Before concluding this reply there are a few more objections which Mr. Wright does me the honour to make, that must be noticed one after the other.

I am represented as passing an unfair judgment, because I say that though feeling myself incompetent to advance an opinion as to the correctness of Sir William Thomson's astronomical calculations, I yet assert ' that the fact that they have not been refuted pleads strongly in their favour, when we consider how much they tell against the theory of Mr. Darwin.' For my part I am unable to see how an incompetence for judging astronomical calculations necessarily carries with it an incompetence for judging of the probability of their truth, resulting from their non-refutation by those whose interest would lead them to refute, and who possess the knowledge and ability to enable them ably to handle the requisite questions and calculations. 
Again, Mr. Wright does not 'see how, with such uncertain, "fortuitous, occasional, and intermitting" elements' I 'could have succeeded in making any calculation at all.' I venture to think, however, that an inability to determine the positive time required for the occurrence of certain phenomena in no way involves an inability to fix a minimum period for their development.

Again, in eriticising the use of the words 'contrivance' and 'purpose,' Mr. Wright tells us, ' The relations of a machine to its uses may be considered in good sound English as contrivances and purposes, without thinking of what the inventor intended.' Now I deny that we can so speak without implicit reference of the kind, though we need not make direct or explicit reference. We are also told that 'the proper meaning of the word "intention" is concentration, and the not intending of something else.' I should be glad of some reference to authorities as regards this assertion. As a fact the word is used in the sense I have assigned to it. Finally Mr. Wright gives us the application of these new definitions. He affirms that Mr. Darwin is not irrational in asking whether 'the Creator intentionally ordered' certain phenomena, because we cannot reasonably make use of the term 'intention' in reference to the Creator at all.

It is evident, however, that in Mr. Darwin's opinion we can speak of Divine intention in some things, otherwise he would not ask whether we could do so or not even in these. It would be quite superfluous for any one who believed we could do so in no case to ask the question with regard to certain special cases. The criticism merely amounts to saying that both Mr. Darwin and I, instead of using the word ' intention,' should employ some other, possibly 'advertence.' This leaves the substance of my remarks and my criticism of Mr. Darwin quite unimpaired and in full force.

Thus I venture to urge, in opposition to my critic, that 
far from misinterpreting Mr. Darwin, I have been enabled to bring out more clearly what are his exact position and teaching now, by defining more exactly what was his original theory of the origin of species.

Also, that though by no means necessarily involving irreligious or anti-teleological conceptions, there is no slight danger of the strengthening of these errors by a certain use of the Darwinian theory.

My little book was directed to two objects,-one to show that Natural Selection is not the origin of species; the other that Evolution is perfectly compatible with the strictest Christian orthodoxy: and, in spite of my esteem for $\mathrm{Mr}$. Chauncey Wright, and a careful and respectful consideration of all that he has urged, I cannot at present see my way to retracting or even modifying, in deference to his criticism, one single passage of my work on Specific Genesis. 


\section{HERBERT SPENCER.}

1. Principles of Psychology. By Herbert Spencer. London, 1872.

2. First Principles. By Herbert Spencer. London, 1867.

3. Essays. By Herbert Spencer. London, 1868.

MR. HERBERT SPENCER has been termed by Mr. I. Darwin 'our great philosopher'; and there is no doubt that he is regarded by a select body of admiring disciples as the paramount authority, on all philosophical questions. Nor are we disposed to question his intellectual achievements. Possessing as he does an acquaintance with almost all branches of physical science, together with a singular quickness in the detection of analogies, and much analytic power, he has the good fortune to be also able to manifest his wealth of thought by a corresponding richness of diction, his style being clear and forcible, abounding in picturesque illustrations, aptly chosen for the purposes they are intended to subserve, and often possessing even a poetical beauty. Vigorous and well-exercised natural faculties have enabled him to gather up within his delicate yet nervous grasp, not only the multitudinous threads spun by the various discoverers in physical science, but also those yet more subtle fibres which our recent best-known psychologists have drawn forth; weaving the whole, with dexterous skill, into an intellectual fabric of great delicacy and apparent cohesion.

Mr. Spencer has indeed so co-ordinated, supplemented, 
and developed the doctrines of his contemporaries and immediate predecessors that the philosophy he sets before us is the very culmination of their efforts-the bloom and fructification resulting from long-continued anterior processes of growth. Not only if his philosophy is true should we be thankful to him, but also if it is false; since we may be sure that if he fails to convince, it is from no deficiency of his, but from a fatal defect in his cause-a defect only made the more patent by the ability of its advocate.

The prolonged dispute, between those who assert and those who deny that all our ideas are modified sensations and no more, has undergone a strange transformation within the last quarter of a century, and with this transformation we witness as strange a reaction. The ambiguity of Locke caused his system to be developed by Hume, through Berkeley, into scepticism, and by Condillac into unmitigated materialism. These results were the occasion of that Kantian resurrection hailed throughout the Continent as a philosophical system finally and triumphantly refuting the school of empiricism. They were also the occasion of the parallel movement in Great Britain of Reid and his followers-a movement less developed and less conspicuous than was the reaction under Kant on the European mainland. The event has shown, however, that sensationalism was scotched, not killed. In spite of Royer-Collard, Maine-de-Biran, Jouffroy, and Cousin, the grossest sensationalism has reappeared in France through Auguste Comte. In Britain, the successors of Reid-Sir William Hamilton, Mansel, and M'Cosh-have all been unsuccessful in exorcising the sensational spirit, and though Mr John Stuart Mill (as almost a pure Lockian) may be regarded as an instance of philosophical 'survival,' yet Hume lives again in Huxley and in Lewes; and indeed (however they may differ as to subordinate questions) Messrs. Spencer, Bain, Mill, Huxley, and Lewes, unite in an essential 
and fundamental agreement with the great sceptic of Scotland.

Thus though fifty years ago the world of thought pronounced Hume for ever defeated by Kant, we find Hume once more in possession of the field; and even the extreme sensationalism of Condillac is justified, nay, demonstrated to be inevitable truth, by the author who here concerns us. Indeed Mr. Spencer may, in a certain sense, be deemed the legitimate descendant and representative of Locke, as understood by those who refuse to attribute to the term 'reflexion,' as used by him, a meaning which would stultify him as to his whole philosophical position.

An inquiry into the causes of this untoward resurrection would be full of interest, but cannot, as too remote from the matter in hand, be here pursued. The mere existence, however, of such a revival would seem to demonstrate that the Professor of Königsberg did not dig deeply enough in his attempted process of eradication. But Mr. Spencer is far from being a mere reviver of Hume, of Locke, or of any other philosopher. Indeed, as we shall presently see, he differs from Locke in admitting, in a certain sense, 'innate ideas,' while he combats Hume with vigour and efficiency, and may not improbably quite repudiate the imputation of being a disciple of that philosopher.

It is as the philosophical embodiment of modern physical science that Mr. Spencer is pre-eminently distinguished. Science has indeed made vast acquisitions since the time of Hume, and the stored-up accumulation of its facts contains materials calculated to affect powerfully the imagination of mankind. Now Mr. Spencer's philosophy is replete with conceptions and inferences derived from that accumulated treasure. It is by such scientific progress, by the indirect influences of physical science on philosophy, that this development of reactionary sensationalism must be explained. New

VOL. II. 
issues have been joined, and the point of view having been shifted, controversies deemed closed have to be reconsidered. This reconsideration has become requisite, not through want of conclusiveness in the earlier replies to the argument as then conducted, but through the fresh lights now let in at apertures in dividing walls which then seemed of unbreachable solidity, and which give to old facts a quite new aspect.

The dispute as to our possession of ideas and conceptions which no experience of any single life, however prolonged, can explain-the existence, that is, of an $\alpha$ priori element in our knowledge-may be considered to have ended in the nineteenth century with the triumphant refutation of those sensationalists who denied the existence of such an element. This refutation Mr. Spencer not only fully accepts as valid, but he actively co-operates in demonstrating the absurdity of the belief that the mental phenomena of any one life, however prolonged, are sufficient to account for such conceptions as extension, causation, objectivity, and existence.

The opponents of sensism, however, must be prepared to take small comfort from such acceptance and seeming aid, for Mr. Spencer is really one of their most formidable enemies; and he claims to have demonstrated by a combined system of $\dot{a}$ prior $i$ and $\dot{a}$ posterior $i$ proof that sensation and all intellectual action are fundamentally one and the same, and that (sense being primary) every idea is made up of transformed sensations. This demonstration is accomplished by means of the doctrine of Evolution, which has of late attained so wide a currency and such general acceptance. According to this doctrine all the varied organisms inhabiting this planet have been gradually produced one from another by merely natural processes, and, as Mr. Darwin would fain have us believe, mainly by the action of 'Natural Selection.' In this way Mr. Spencer conceives that what is a priori to the individual is but a posteriori to the race, and 
he thus claims to have reconciled the two schools of thought, namely, those who assert and those who deny the derivation of all our ideas exclusively from sensation and experience. As is manifest, however, he gives the substantial victory entirely to the sensists, and denies to all ideas any higher origin than mere incipient sentiency. It is plain, then, that the old battle has to be fought again on new ground, and no argument can be henceforth admitted as valid until it has stood the test of examination in the light of the theory of evolution.

The effect which this theory has had on philosophy is small compared with that which may be yet to come. Its most modern advocates, such as Dr. Bastian, are not content with driving back 'experience' to the lowest forms of animal or even of vegetable life, but teach that one physical process of change-redistribution of matter and motion-results successively in chemical integration and aggregation, the formation of organisms, life, feeling, thought, memory, love, and will. Even Professor Tyndall, in spite of his opposition to Dr. Bastian, is fundamentally at one with him, and speaks of the genius of Plato, Shakespeare, Newton, and Raffaele, as latent and potentially existing in the fires of the Sun, and being the ultimate outcome of an unconscious primeval mist.

Mr. Spencer exhibits to his readers the evolutionary theory (as understood by the school which identifies man with brutes) in its most attractive and most persuasive form. All, probably, that can well be said for it by any one is said by him; every objection that can be made against it by those who do not share the views advocated in this Review seems to have been foreseen and replied to with a wealth of illustration and a force of logic hardly to be exceeded. If therefore he fails, the theory he so ably advocates is indeed discredited. If it can be shown that his whole system reposes upon fatal and fundamental error, the same defect, of 
course, vitiates the argument of the whole school he represents, in so far as that school rests on the same basis. Hence it is of great importance that the foundations of his system should be tested with all possible care; for if those foundations are solid, the skill of the architect is too great for us to expect to find weakness and insecurity in any portion of the superstructure.

No one who knows anything of philosophy will for a moment suppose that a general examination of Mr. Spencer's whole system can be effected within the limit of this essay: it will be only possible for us to glance at a few of its more obvious features. We would especially direct attention to two points, to both of which we are confident objections may be made; and although Mr. Spencer has himself doubtless considered such objections (and they may well have struck many of his readers also), we nevertheless do not observe that he has anywhere noticed or provided for them.

The two points we so select are:-

(1) That his system involves the denial of all truth.

(2) That it is radically and necessarily opposed to all sound principles of morals.

In proceeding to establish these points, we would repeat our high admiration for Mr. Spencer's intellectual and moral character, and would repudiate in the strongest terms the slightest intention of making any reflection upon Mr. Spencer personally, while we state the grave objections to which his philosophical system seems to us open.

If there is one fundamental characteristic of Mr. Spencer's philosophy, it is its emphatic assertion of the relativity - the merely phenomenal character-rof all our knowledge. But this fundamental position is not by any means special and peculiar to Mr. Spencer, but is the common property of the whole school of modern Humists, such as Messrs. Mill, Lewes, Bain, and Huxley. With Mr Spencer the relativity of know- 
ledge is the theme of two successive chapters in the early part $^{1}$ of his Psychology -as also under the head of 'Transfigured Realism,' towards the end of that work-and it is fully enunciated in his First Principles. That we can know nothing but phenomena, that everything absolute escapes us - as being for ever unknowable and beyond the ken of the human intellect-is a cardinal principle with Mr. Spencer, who distinctly tells us ${ }^{2}$ that all 'objective agencies' productive of 'subjective affections' are not only 'unknown' but also 'unknowable.'

But every philosophy, every system of knowledge, must start with the assumption (implied or expressed) that something is really 'knowable'-that something is 'absolutely true'; and in the present instance it is evidently intended to imply that the doctrine of the 'relativity of all our knowledge' is a doctrine which is really and absolutely true. But if nothing that we can know corresponds with reality, if nothing we can assert has a more than relative or phenomenal value, why does not this character also appertain to the doctrine of the relativity of all our knowledge? Either this system of philosophy itself is relative and phenomenal only, or it is absolutely and objectively true. But it must be merely phenomenal, if everything known is merely phenomenal. Its value, then, can be only relative and phenomenal - that is, it has no absolute value, does not correspond with objective reality, and is therefore false. But if it is false that our knowledge is only relative, then some of our knowledge must be absolute; but this negatives the fundamental position of the whole philosophy.

Any philosophy then which starts with the assertion that all our knowledge is merely phenomenal refutes itself, and is necessarily suicidal. Every asserter of such a philosophy must be in the position of a man who saws across the branch

${ }^{1} \mathrm{Vol}$. i. part ii. chaps. iii. and iv. pp. 193-227. $\quad{ }^{2}$ Vol. iii. p. 493. 
of a tree on which he actually sits, at a point between himself and the trunk. If he would save himself, he must refrain from destroying that which alone sustains him in his elevated position. The validity of human reason then, by a just retribution, asserts itself by the very reasoning of those who would explicitly deny its competency to apprehend what is 'absolutely true,' and who would confine it to the 'relative' and the 'phenomenal.'

Our readers will very reasonably suspect that we must have misread Mr. Spencer; they will hardly deem it possible that he can have involved himself in what, when thus nakedly put before them, seems so obvious a self-contradiction. But it will perhaps appear less incredible that he has fallen into this error when we have compared together different parts of one and the same of Mr. Spencer's works, so as to be able to realise how completely he seems to contradict himself. We shall see, indeed, that our author, in spite of the general clearness of his style, has in his Psychology the appearance, as it were, of playing 'fast and loose' with the fundamental question of the objective validity of our cognitions, and this necessarily results in such obscurity as may well be the occasion of involuntary misrepresentations on the part of the most benevolent of critics.

In the seventh part of that work Mr. Spencer justifies in several ways what he calls 'realism,' that is, the belief that the external, material world really exists objectively, and 'in such a way that each change in the objective reality causes in the subjective state a change exactly answering to it-so answering as to constitute a cognition of it.' 1 This view he justifies by an argument from 'priority, i.e. from the fact that the realistic conception is prior to the idealistic conception, so that 2 ' in no mind whatever can the Idealistic conception be reached except through the Realistic one.' He also

\footnotetext{
${ }^{1}$ Psychology, vol. ii. p. 497. The italics are ours.

2 Op. cit., p. 374.
} 
justifies it by an ' argument from simplicity,' which consists of a demonstration that, if our conviction of the world's existence be not an intuition but an inference, then the system of Idealism is an inference indefinitely more cumbrous and complex and therefore more liable to error. He says :- ${ }^{1}$

'While the first involves but a single mediate act, the second involves a succession of mediate acts, each of which is itself made up of several mediate acts. Hence, if the one mediate act of Realism is to be imvalidated by the multitudinous acts of Idealism, it must be on the supposition ... that if there is doubtfulness in a single step of a given kind, there is less doubtfulness in many steps of this kind.'

Finally, he advances an 'argument from distinctness,' which reposes on the far greater vividness of sensations than of ideas, which, according to Mr. Spencer, are but plexuses of faint sensations. He also ${ }^{2}$ opposes thinkers of the schools of Hume, Berkeley, and Kant, and asserts that their very expositions of idealism cannot be made without the use of terms which imply that very realism they deny. Here, then, we are led to infer that the common belief is valid, and that Space, Time, Figure, Number, Extension, Motion, etc., really exist objectively as they are subjectively apprehended. It must be so, since no system can be deemed either primitive, simple, or distinct which asserts that neither extension, nor figure, nor number is in reality what it appears, or that the objective connections amongst these properties are what they seem to us to be, and that ${ }^{3}$ ' what we are conscious of as properties of matter, even down to its weight and resistance, are but subjective affections produced by objective agencies which are unknown and unknowable.' Yet this is the result actually arrived at by our author-a result which to most will appear little distinguished from scepticism, since it is admitted by him to agree with idealism and scepticism in affirming that the subjective modification of consciousness in the perception
${ }^{1}$ Op. cit., p. 378.
${ }^{2}$ Op. cit., pp. 312-366.
${ }^{3}$ Op. cit., p. 493. 
of any external body 'contains no element, relation, or law that is like any element, relation, or law' in such external body. Thus the universe as we know it disappears not merely from our gaze but from our every thought. Not only the song of the nightingale, the brilliancy of the diamond, the perfume of the rose, and the savour of the peach lose for us all objective reality-these we might spare and live-but the solidity of the very ground we tread on, nay, even the coherence and integrity of our own material frame, dissolve from us, and leave us vaguely floating in an insensible ocean of unknowable potentiality. And this is REALISM; this is what is justified to us by being primitive, simple, and distinct, as being prior to idealism, 'everywhere and always, in child, in savage, in rustic, in the metaphysician himself.' 1

Mr. Spencer may well call this 'Transfigured Realism.' If he were to invite hungry men to a feast, and, having discoursed to them on the digestibility of sauces and meats, the relations of appetite, digestion, nutrition, were afterwards to lead them into a room garnished with tables of the chemical formulæ of animal substances, the disappointment of his guests would hardly be less great than that of many readers who, having read his arguments from priority, simplicity, and distinctness, come finally upon 'transfigured realism' as the result. We are, of course, quite aware of the distinctions drawn by Mr. Spencer between what he calls crude realism and the realism adopted by him, but whether or not his metaphysical position be tenable, we are quite certain it cannot be defended by arguments which are valid only to support that dualism, that distinctness yet true correspondence between matter and mind, which has been, and ever will be, the natural and practically ineradicable, spontaneous conviction of mankind.

$\mathrm{Mr}$. Spencer would probably have avoided this and other ${ }^{1}$ Psychology, vol. ii. p. 374. 
ambiguities and more or less seeming contradictions if the method of his Psychology had been less faulty. That work consists of two volumes, divided into eight parts (five of the eight being contained in the first volume), the distribution of which is such that the reader is led to and from objectivity to subjectivity in a way which it is perplexing to follow. After an opening, treating of the anatomy and physiology of the nervous system, we are taken in the second part to pure subjective psychology. The third part reverts to anatomy and physiology, and the various adjustments found, in different groups of animals, between their nervous structure and the conditions of their life; while in the fourth part these adjustments are brought into relation with pure or subjective psychology. In the fifth part he connects his psychological facts and doctrines with the general law of the evolution of the whole universe as conceived by Mr. Spencer. In the sixth part we are once more in subjectivity, logical relations, the fundamental and ultimate relations of states of consciousness. The seventh part is frankly metaphysical, and we have already referred to its outcome-Mr. Spencer's 'transfigured realism'; while the eighth and last part deals with the emotions, and considers psychology in such a manner as to serve as an introduction to his work on Sociology, which is soon to follow.

In this arrangement, Mr. Spencer has departed from the order he adopted in the first edition of his Psychology, wherein he treated of the subjective phenomena of mind before proceeding to the consideration of physiology. Under the existing conditions of philosophical controversy, we cannot but think the change unfortunate. As long as the objective validity of subjective conceptions is in dispute, objective truths should not first appear in the field. In a controversy wherein 'states of consciousness' are the ultimate criteria, it must be a mistake to begin with considering the structure 
and functions of nerve fibres and nerve cells, the very objective existence of which is as yet unjustified. We fully agree with a declaration elsewhere ${ }^{1}$ made by Mr. Spencer when he says-'Clearly, then, the metaphysician's first step must be to shut out from his investigation everything but what is subjective; not taking for granted the existence of anything objective corresponding to his ideas, until he has ascertained what property of his ideas it is which he predicates by calling them true.' It seems to us manifest that the psychologist's first business is to settle an ultimate criterion, and to show what must necessarily be postulated if we would rise from utter and absolute scepticism. Were it not for the prevalent cavils against human intelligence, we should heartily approve of starting from objectivity, and so making a progressive ascent from mere nutrition to the most abstract intellectual action, according to the great example of psychological investigation given to us by Aristotle. But such a process cannot now be followed without falling into a petitio principii. Now, it is necessary first to justify our perceptions and our reasonings, and only after such an introduction can we logically proceed to investigate the universe of objective being.

We may now pass to matters supplementary to our first point, and consider the bearing upon our perception of truth of some positions more peculiar to Mr. Spencer himself, and not shared by all those who generally agree with him. And here we would express hearty thanks to our author for the vigour, persistency, and skill with which he has exhibited the question as to the ultimate foundation of philosophy and the true basis of certitude. Although, as we have seen, in order to be perfectly consistent, Mr. Spencer ought to deny the existence of any basis of certitude, or of any absolute and fundamental truth, yet, by a happy incon-

${ }^{1}$ Essays (stereotyped edition, 1860), vol. ii. p. 400. 
sistency, he lays down the necessity of primary undemonstrable truths underlying the whole fabric of knowledge. We cite with pleasure the following statements, which seem to us to be as true and valid as they are admirably expressed. In criticising 'Empiricism' or 'Experientialism,' he says :-1'

'Throughout its argument there runs the tacit assumption that there may be a philosophy in which nothing is asserted but what is proved. It proposes to admit into the coherent fabric of its conclusions no conclusion that is incapable of being established by evidence; and thus it takes for granted that not only may all derivative truths be proved, but also that proof may be given of the truths from which they are derived, down to the very deepest. The consequence of this refusal to recognise some fundamental unproved truth is that its fabric of conclusions is left without a base. Giving proof of any special proposition is assimilating it to some class of propositions known to be true. If any doubt arises respecting the general proposition cited in justification of this special proposition, the course is to show that this general proposition is deducible from a proposition of still greater generality; and if pressed for proof of such still more general proposition, the only resource is to repeat the process. Is this process endless? If so, nothing can be provedthe whole series of propositions depends on some unassignable proposition. Has the process an end? If so, there must eventually be reached a widest proposition - one which cannot be justified by showing that it is included by any wider-one which cannot be proved. Or to put the argument otherwise :-Every inference depends on premises; every premise, if it admits of proof, depends on other premises; and if the proof of the proof be continually demanded, it must either end in an unproved premise, or in the acknowledgment that there cannot be reached any premise on which the entire series of proofs depends.

'Hence philosophy, if it does not avowedly stand on some datum underlying reason, must acknowledge that it has nothing on which to stand-must confess itself to be baseless.'

But the question immediately arises, ' How are unproved and unprovable self-evident truths to be sought?' Mani-

1 Psychology, vol. ii. p. 391. 
festly by introspection alone-the careful analysis of consciousness by each one for himself. In order successfully to combat with those who accept idealism, we must, for the sake of those who do not accept the nature-given bridge between object and subject, begin from a purely subjective basis. This, as we have already seen, is the method declared necessary by Mr. Spencer himself, and he also tells us ${ }^{1}$ to the same effect:-

'The first step in a metaphysical argument, rightly carried on, must be an examination of propositions for the purpose of ascertaining what character is common to those which we call unquestionably true, and is implied by asserting their unquestionable truth. Further, to carry on this inquiry legitimately, we must restrict our analysis rigorously to states of consciousness considered in their relations to one another: wholly ignoring anything beyond consciousness to which these states and their relations may be supposed to refer. For if, before we have ascertained by comparing propositions what is the trait that leads us to class some of them as certainly true, we avowedly or tacitly take for granted the existence of something beyond consciousness; then, a particular proposition is assumed to be certainly true before we have ascertained what is the distinctive character of the propositions which we call certainly true, and the analysis is vitiated. If we cannot transcend consciousness-if, therefore, what we know as truth must be some mental state, or some combination of mental states; it must be possible for us to say in what way we distinguish this state or these states. The definition of truth must be expressible in terms of consciousness; and, indeed, cannot otherwise be expressed if consciousness cannot be transcended.'

Now, although we have the good fortune to agree, to a certain extent, with Mr. Herbert Spencer as to the limits and necessary conditions of inquiry, yet our view as to the ultimate and final test of all truth whatever differs profoundly and fundamentally from his. We differ from him, and deem his conception of this test to be inadequate and

1 Essays, vol. ii. p. 381 (stereotyped edition). 
false, because he makes that test a purely negative one. $\mathrm{He}$ asserts that 'inconceivability' is the ultimate and supreme test, of truth. He tells us :-1

'A discussion in consciousness proves to be simply a trial of strength between different connections in consciousness-a systematised struggle serving to determine which are the least coherent states of consciousness. And the result of the struggle is, that the least coherent states of consciousness separate while the most coherent remain together; forming a proposition of which the predicate persists in the mind along with its subject. ... If there are any indissoluble connections, he is compelled to accept them. If certain states of consciousness absolutely cohere in certain ways, he is obliged to think them in those ways. . . Here, then, the inquirer comes down to an ultimate uniformity - a universal law of thinking.'

We have said we consider Mr. Spencer's test inadequate, and we do so because we are convinced that his analysis of consciousness is incomplete and misleading. He fails to distinguish between two distinct classes of ultimate psychical phenomena, and consequently does not really accept, as he professes to do, the absolute dicta of consciousness for the basis of his philosophy. He fails to distinguish between merely negative mental impotencies or simple inconceivabilities and positive 'convictions' or 'intuitions.' He fails to note the utterly different classes of judgments which severally affirm either that they simply cannot conceive a given proposition to be true, or that they positively do see that the opposite of a given proposition cannot be true. Negative perceptions of simple inconceivability are reflex, but positive intuitions (as when we gaze at a picture on the wall before us) are direct.

Mr. Spencer distinguishes between two classes of unbelievable propositions, namely: (1) the simple unbelievable

${ }^{1}$ Psychology, vol. ii. p. 450. 
or incredible, and (2) the inconceivable. He defines ${ }^{1}$ the former as a proposition 'which admits of being framed in thought, but is so much at variance with experience' 'that its terms cannot be put in the alleged relation without effort'; and he gives as an example-a cannon-ball fired from England to America. An inconceivable proposition is defined by him as 'one of which the terms cannot, by any effort, be brought before consciousness in that relation which the proposition asserts between them'; and he gives as examples of inconceivability 'that one side of a triangle is equal to the sum of the other two sides'; and a little before ${ }^{2}$ the idea of resistance, disconnected from the idea of extension in the resisting object.

Now, in the first place, it must be presumed that with Mr. Herbert Spencer the term 'framed in thought' is equivalent to 'represented in imagination,' and the distinction he draws is as true as obvious between propositions which can be imagined but are not to be believed, and those which cannot be imagined at all. He does not, however, as we have said, distinguish sufficiently between propositions, as a little introspection will convince any unprejudiced experimenter. There are, in fact, not one, but two classes of unimaginable propositions, and it is the second of these (utterly neglected by him) which alone compels the mind to absolute, unconditional, universal, and necessary assent to their contradictories, because their contradictories are seen to be absolutely, unconditionally, universally, and necessarily true.

There are altogether four kinds of propositions in consciousness :-

1. Those which can be both imagined and believed.

2. Those which can be imagined but cannot be believed.

3. Those which cannot be imagined but can be believed.

${ }^{1}$ Psychology, vol. ii. p. 408.

${ }^{2}$ Op. cit., pp. 406, 407. 
4. Those which cannot be imagined and are not believed, because they are positively known to be absolutely impossible.

We need not occupy time with a consideration of the first two kinds, but the latter two require careful discrimination. It is surely somewhat surprising that Mr. Spencer does not discuss the two meanings of the word 'inconceivable,' pointed out long ago in the controversy between Mill and Whewell: The word 'inconceivable' is sometimes taken to denote simply that which the mind cannot picture in a distinct mental image. At other times it is made use of to signify that which is 'unintelligible' or 'unthinkable.' But a great number of things which cannot be pictured to the imagination can most certainly be thought and understood, and none of those who uphold the validity of our intuitions of objective necessary truth pretend that that which cannot be imagined is necessarily untrue. Fortunately in this matter of the declarations of consciousness, the appeal is to facts and experiments-facts that can be observed, experiments that can be carried on by every one a little advanced in philosophy, and therefore possessing that which is a necessary condition of such advance-namely, a habit of careful introspection. We venture confidently to affirm that we have as certain evidence for this distinction of kind between our own thoughts as we have for the very being of those thoughts themselves. The existence of this distinction as a fact is incontrovertible, and the actual presence in consciousness of this declaration should be first carefully noted; its validity may be considered afterwards.

The first class of Mr. Spencer's inconceivable propositions (our simply unimaginable ones) are, or, for all we see, may be, the mere results of mental impotence; they are but negatively and passively inconceivable. The second class of inconceivable propositions (our necessarily false ones) are 
those which are positively and actively inconceivable, because they are clearly known by the mind to be absolutely and universally impossible. At present we have not to consider whether such perceptions are objectively true and valid; but to point out that, as a fact, they subjectively exist.

Let us, then, first note certain propositions which the mind seems impotent to imagine, but which the intellect can both understand and believe. The intellect clearly conceives a force varying inversely as the square of the distance between two bodies it reciprocally affects; yet this variation cannot be adequately represented by any image to the imagination. We can, again, conceive an infinite addition of fractions, which shall yet never attain to unity; but such a conception is utterly beyond the power of the imagination. Again, we can not only conceive but it is evidently a necessary truth that $\left(a^{2}+a b+x\right)+\left(a b-x+b^{2}\right)=(a+b) \times$ $(a+b)$, let $a, b$, and $x$ represent whatever whole numbers they may; but this can by no means be directly represented by the imagination.

But conceptions may be formed as to modes of existence of which we have had no experience whatever, and necessary deductions can even be drawn from such conceptions. Thus Professor Helmholtz has conceived ${ }^{1}$ 'beings living and moving along the surface of a solid body, who are able to perceive nothing but what exists on this surface, and insensible to all beyond it'; and he adds, 'If such beings lived on the surface of a sphere, their space would be without a limit, but it would not be infinitely extended; and their axioms of geometry would turn out very different from ours, and from those of the inhabitants of a plane. The shortest lines which the inhabitants of a spherical surface could draw would be arcs of greater circles'; also there

1 The Academy, vol. i. p. 128. 
would be many shorter lines between the same two points if there were two poles. Moreover, he tells us, such beings 'would not be able to form the notion of parallel geodetical lines, because every pair of their geodetical lines, when sufficiently prolonged, would intersect in two points,' etc. This passage is not only interesting as demonstrating our power of transcending experience by conception, but even more so as the solemn enunciation of a transparent fallacy by a man of eminence. Professor Helmholtz concludes :'We may resume the results of these investigations by saying that the axioms on which our geometrical system is based are no necessary truths.' And Professor Clifford ${ }^{1}$ cites with approval the article here quoted, and adopts its conclusions. Nevertheless the fallacy is surely transparent. Unless geometrical axioms were necessary truths, it would be impossible for these professors to declare what would or would not be the necessary results attending such imaginary conditions. And 'other systems' could not, as Professor Helmholtz admits ${ }^{2}$ they may, 'be developed analytically with perfect logical consistency.' If such beings as are supposed, called the lines referred to 'straight,' they would mean by that word what we should call 'arcs of great circles.' Whether such beings could conceive of parallel lines or not, there is no evidence to show, but there is no shadow of foundation for asserting that, if they could conceive of them, they would not perceive the impossibility of their ever meeting, as we can perceive the necessary relations of their supposed space conditions which, by the hypothesis, are not ours.

Our author, as we have seen, deems it absolutely inconceivable that an unextended object can offer resistance or exercise pressure. Nevertheless Mr. Spencer himself is able to conceive 'body' as really apart from extension, and in ${ }_{1}$ Macmillan's Magazine, Oct. 1872, p. 504. $\quad 2$ The Academy, vol. i. p. 130. VOL. II. 
terms of force only-since that which is described must be conceived; and he tells us ${ }^{1}$ it is 'manifest that our experience of force is that out of which the idea of matter is built. Matter, as opposing our muscular energies, being immediately present to consciousness in terms of force, and its occupancy of space being known by an abstract of experiences originally given in terms of force, it follows that forces, standing in certain correlations, form the whole content of our idea of matter.' But however much it is to be regretted, it is undeniably the fact that very many persons who conceive a pure spirit to be unextended and not to occupy space, find at the same time no difficulty in very distinctly converting in thought that which to Mr. Spencer is inconceivable. Again, the doctrine that the soul is whole and entire in every part of the body is a conception utterly transcending imagination, but one which has been and is accepted, believed, and reasoned about by thousands of the most acute and cultivated intellects. Some not only avow their power of conceiving that space may be bounded, but even announce that we may be shortly enabled to assert its actual extent. ${ }^{2}$

But that perception of necessary truth is not limited by experience may be shown by the fact that we are not compelled to conceive that of which we have, and our ancestors, however remote, have ever had, uniform and unvarying experience. We have ever seen with our eyes and heard with our ears, yet we can conceive of vision and audition taking place in quite other parts of the body instead. We have experience but of the five senses, apart from the muscular sense, yet we can not only believe in the possibility of other senses but conceive the existence of a sense directly

1 First Principles (second edition), p. 167.

2 See Professor Clifford's article in Macmillan's Magazine of Oct. 1872, p. 511. 
revealing to us the actinic properties of light, or the chemical composition of crystals, by special modifications of consciousness, which modifications are now, of course, unimaginable to us. We have never experienced colour apart from extension, nor an extended object not coloured, and yet these properties can be conceived of as distinct though they cannot be so imagined. But an effective argumentum ad hominem may be addressed to Mr. Mill, who tells us he can conceive of two and two making five, for most assuredly such a power transcends the experience of all his ancestors, and will transcend that of his successors to their latest posterity. Indeed, as Mr. Martineau observes,, 'Experience proceeds and intellect is trained, not by association, but by Dissociation, not by reduction of pluralities of impression to one, but by the opening out of one into many; and a true psychological history must expound itself in analytic rather than synthetic terms.' But what is experience? A stone cannot 'experience,' nor can experience be taken as ultimate. The very acquisition of experience implies innate laws or principles. Instead of experience being able to account for innate principles, innate principles are needed to explain the acquisition of experience.

Let us now consider those propositions which are deemed by the mind to be necessary and universal, not from a passive impotence to dissociate two mental images ${ }^{2}$ (such as those of colour and extension), but from an active power of positive perception of which the intellect is self-conscious. It requires but a little candid introspection to see how different is the mental declaration with regard to those unimaginable conceivabilities we have noticed, and such

1 Essays, p. 271.

2 There is not space in this essay to consider the statements of those who deny that they have such intuitions. There will not be the slightest difficulty, however, in showing, on another occasion, that they contradict themselves. 
propositions as that "things that are equal to the same thing are equal to each other'; 'a thing cannot both be and not be at the same time in the same sense.' The subjective difference is surely plain enough. Every sane man must admit that he clearly sees-sees borne in on $\operatorname{him}^{1}$ as necessary truths-that two straight lines can never enclose a space; that twice five must always be ten; and that ingratitude can under no circumstances be a virtue. If a man denies that he perceives these judgments as necessarily true in any conceivable case as it arises, then he either does not understand the real meaning of such judgments-in $\mathrm{Mr}$. Spencer's ${ }^{2}$ words, 'they have not clearly represented to themselves the propositions they assert'-or his mental condition is pathological.

The judgment that the three angles of a triangle should be together equal to two right angles, we perceive to be a mental fact of quite a different kind from our inability to imagine unextended colour or a boundary to space. Such a judgment we see, if we can see anything, to be one the falsehood of which is not negatively unthinkable, but absolutely and positively impossible even to Omnipotence itself, and this because we see the affirmative to be absolutely and necessarily true. Moreover, of all our subjective certainties none are to each one so certain as that which affirms those judgments which (rightly or wrongly) we deem absolutely and universally necessary. If then subjective certainty is our ultimate test, such judgments override all others; and to deny them invalidates every possible judgment, and logically plunges the doubter, if he is consistent, into absolute, unqualified scepticism. The actual presence of these supreme and active perceptions as to necessity and impossibility (the existence of which as distinguished from negative inconceivabilities is ignored by Mr. Spencer) may

1 Essays, p. 322.

${ }^{2}$ Op. cit., p. 372. 
be taken as one of the most certain and indubitable facts of consciousness.

If there was but the one kind of inconceivable propositions-namely those negatively inconceivable, we should be driven, as Mr. Spencer says, to accept them as limits for us whether objectively and universally valid or not. But the recognition of the quite other kind of active, positive perceptions of inconceivability (of perceived universal impossibility), together with the recognition that these looked at from the point of view of pure subjectivity assert themselves as supreme, either give us full warrant to assert universally necessary truth, or logically force us, if we decline to accept such truth, into the chaos of universal doubt.

Mr. Spencer has justly observed that the passive inconceivabilities are necessities of thought to us, and that by refusing to accept them we pass into a state of mental confusion, and even more or less physical impotence must result from a refusal to act as if they were valid. This confusion and this impotence can be remedied only by a practical acceptance of their objective validity. In the same way the convictions forced upon us by our supreme intuitions as to impossibility and necessity, are practically active necessities of thought. Every man is spontaneously convinced of their necessary truth and acts on such conviction in every case as it arises seriatim to his mind, by a spontaneous judgment accordingly. If in reflecting on such spontaneous active judgments we begin to doubt as to their objective validity, we begin ipso facto to undergo a process of mental disintegration and intellectual paralysis, only to be remedied by the acceptance of the objective validity of such truths. The objective validity of these perceptions is given in the very substance of each such perception itself. To doubt of the objective truth of each, is to doubt that of which we are directly and supremely certain. If two straight lines can 
enclose a space, and if a whole may be less than its part, then we have no certainty but that the same thing cannot both 'be' and 'not be' at the same time and in the same sense, and we are landed in utter and complete scepticism. But Mr. Spencer himself has implicitly admitted this very distinction which he explicitly ignores, and not only recognises an active power of positively perceiving necessary truths, but also the distinction between actual and possible being. He says ${ }^{1}$ - speaking of the inquiry after fundamental truth-' Hence he has no appeal from this ultimate dictum; and seeing this, he SEES that THE ONLY POSSIBLE further achievement is the reconciliation of the dicta of consciousness with one another.' Any one, however, who should deny that we have, as a fact, an intuition of 'objective, universal, and absolute necessity,' may be confuted by bringing forward the simple fact that some men assert that they have that idea, and that the very opponents of such asserters must themselves have it also, since they could not argue against and controvert that of which they have no knowledge. $\mathrm{Mr}$. J. Martineau, in criticising Mr. Mill, observes :- ${ }^{2}$

'When he' [Mr. Mill] ' says outright that à priori beliefs really inherent in the mind are totally unworthy of trust, however imperiously they may compel submission; and when he casts about for some appeal against them-either from thought to "fact" or from faculty to faculty - he seems to lose all his logical bearings, and forget the base he had measured. What security can there be for any truth-of "fact" or of thought-à posteriori or à priori-if the positive and primary affirmations of our mental nature may be suspected of making fools of us? The assumption of unveracity once made cannot arbitrarily stop with the province which $\mathrm{Mr}$. Mill wishes to discredit. He himself also must, somewhere or other, come to an end of his "evidence" and "proof," and be landed on principles not derivative but primary: and then he must either accept their coercion "because there is no use in appealing from it," or

${ }^{1}$ Essays, vol. ii. p. 407.

${ }^{2}$ Essays, p. 103. 
unconditionally rely on them as the report of truthful faculties; and in either case is on the same footing as his a priori neighbour. Be the "proof" what it may which authenticates the belief, it is the faculty which, in the last resort, authenticates the proof.'

In the controversy, therefore, between Mr. Spencer and Mr. Mill it appears to us to be clear that both are right and both are wrong. Mr. Mill we deem right in affirming that there are inconceivabilities which may yet be believed, but wrong in denying that our subjective judgments as to impossibility and necessity are both objectively valid and supreme criteria of truth. Mr. Spencer seems to us right in affirming that the ultimate declarations of our intellect are such supreme criteria of truth, but wrong in declining to attribute to such declarations absolute necessity and universal objective validity. But we are convinced that both Mr. Mill and Mr. Spencer err in failing to distinguish between (1) that negative inconceivability which comes from impotence or lack of experience; and (2) that positive, active perception of impossibility which comes from intellectual power and light. It is this active perception which reveals to us truths, neither the result of mere experience nor of logical ratiocination; since they are no sooner thought of than we assent to them, and the validity of all generalisation and deduction rests upon them as upon original and fundamental principles.

The following propositions seem, then, to be incontrovertible:-

1. Knowledge must rest on truths which are incapable of being proved, but are evident by their own intrinsic light, otherwise we have either absolute scepticism or a regressus ad infinitum.

2. These fundamental truths must be subjectively evident.

3. Such fundamental subjective truths declare their objective, absolute, and universal truth. 
4. The intellect is thus carried by its own force from subjectivity to objectivity.

From this it follows that we have a supreme degree of certainty as regards a variety of objective truths which the intellect has the power of apprehending by the aid of sensible phenomena. Our rational nature is thus seen to be capable of knowing truly what is within its range, and is justified in its conviction as to metaphysical certainty. The same degree of inevitable certainty, guarded by the same penalty of absolute scepticism, attends other dicta. That 'whatever thinks exists' is known to us as necessary a priori truth by its own evidence, but that I myself exist is known to me, not by evidence of any kind, but by consciousness, to be a particular contingent fact of supreme certainty.

Mr. Spencer is hardly clear in his enunciations as to our knowledge of our own continued personal existence. In his chapter on 'The Substance of Mind,' 1 he remarks :-

"If by the phrase "substance of mind" is to be understood Mind as qualitatively differentiated in each portion that is separable by introspection but seems homogeneous and undecomposable, then we do know something about the substance of mind, and may eventually know more. Assuming ${ }^{2}$ an underlying something, it is possible in some cases to see, and in the rest to conceive, how these multitudinous modifications of it arise. But if the phrase is taken to mean the underlying something of which these distinguishable portions are formed, or of which they are modifications; then we know nothing about it, and never can know anything about it.'

Now if by this Mr. Spencer means we cannot know our own soul otherwise than in and by its acts, he only asserts what has been ever taught by the schools to which he is the most opposed. No rational metaphysician ever taught that the soul could be known by us in its essence or otherwise than by its acts. But if by the passage quoted he would deny that we have direct consciousness of an enduring

\footnotetext{
${ }^{1}$ Psychology, vol. i. p. $145 . \quad{ }^{2}$ It may well be asked, On what ground?
} 
and persistent self known to us by its acts, as the author of our volitions and the subject of our feelings and cognitions, then we might equally deny that Mr. Spencer has, or ever can have, any knowledge of any friend, as, e.g., of Professor Tyndall. If by Professor Tyndall is to be understood a plexus of sensible accidents - an entity 'qualitatively differentiated in each portion that is separable by thought'-then Mr. Spencer may ' know something' about Professor Tyndall, ' and may eventually know more.' But if the name is taken to mean the underlying something which is now speaking, now silent, now on the Alps, now at the Royal Institution, at one time a boy, at another a man, which has a certain expression of face, a certain habit of dress, a certain mode of carriage, a certain cast of thought-then Mr. Spencer knows 'nothing about it, and never can know anything about it,' since he can never know his friend but by and through some act, were it only by action on the retina of Mr. Spencer or by some active impressions on his auditory nerves. But we have said Mr. Spencer is hardly clear in this matter, and, we may add, he is hardly consistent. He is not so, because if there is one prominent feature of his teaching, it is the supreme certainty borne in on us of the existence of what he calls the absolute and unmodified 'Unknowable.' Yet all that Mr. Spencer brings against our consciousness of the Ego may be brought against his Unknowable. If everything that we know is a form of the Unknowable, then the Unknowable is modified, and the absolute or unmodified Unknowable is an absurdity. Similarly, that we cannot know the Ego except as 'qualitatively differentiated' is most true, but it is true for the very simple reason that it never exists except in some state. A qualitatively undifferentiated Ego is a pure absurdity and an impossibility. No great wonder, then, that our intellects do not apprehend it. But an attempt to deny our knowledge of the substantial Ego, without at the same 
time implicitly asserting that knowledge, is really an effort to escape self-consciousness, which can be but very inadequately represented by the conception of a man trying to jump away from his own shadow.

Before passing from our first point (the relation of $\mathrm{Mr}$. Spencer's philosophy to our perception of truth) there is another matter which should not be passed over, namely, the 'law of contradiction.' One would have thought that this law would have been fully admitted by Mr. Spencer, as it has been by almost every other philosopher. It is strange that any one should think that the law of contradiction is derivative, or that it reposes on anything stronger and more fundamental than itself. Yet this is what Mr. Spencer appears to do. That the same thing cannot both 'be' and 'not be' at the same time, and in the same sense (i.e. the law of contradiction), we maintain to be an à priori necessity of thought-not negative, the mere result of a mental impotence, but given positively, and known to us by its own evidence. If anything may both be and not be at the same time, the whole world beyond conscious self-existence is at once a chaos, and all argument unmeaning. Yet though Mr. Spencer denies ${ }^{1}$ the validity, as an ultimate truth, of the principle of contradiction, he unconsciously affirms it. He affirms it, moreover, in that which he represents to be absolutely fundamental and ultimate, namely, our inability to dissever certain conceptions. For, supposing we know that we have tried to dissever such conceptions and failed, how can we be certain that we have not at the same time not tried and yet succeeded-except upon that very principle of contradiction itself?

Leaving now the question of the relation of this philosophy to our perception of truth, we may pass to our second main point-namely, its relation to morality. In the first

${ }^{1}$ Psychology, vol. ii. pp. 424, 425, from 'But even' to 'invalidity.' 
place the process of Evolution, as understood by Mr. Spencer, compels him to be at one with Mr. Darwin in his denial of the existence of any fundamental and essential distinction between Duty and Pleasure. Virtuous lives are represented as mere results of the continuation of that same process which has produced the association of wolves in packs or hornets in a nest. Brutal passions - the desire to pursue and prey upon a victim or to escape such pursuit, or the gross appetite of sex, are given to us as the ultimate components at once of our loftiest aspirations and of our tenderest feelings -of the most refined human affection and of our sense of awe at the Divine Majesty itself. We yield with much reluctance to the necessity of affirming that Mr. Spencer gives no evidence of ever having acquired a knowledge of the meaning of the term 'morality,' according to the true sense of the word. Nevertheless this defect, on his part, ought not to surprise our readers, since 'Virtue' and 'Goodness' are words which can have no rational or logical place in the vocabulary of any one who accepts Mr. Spencer's views. This is the case, since he explicitly and utterly denies every element of freedom to the human will--a fatal but necessary consequence of his denial of the persistent and substantial Ego. He says :- 1

'Considered as an internal perception, the illusion' [of human freedom] ' consists in supposing; that at each moment the ego is something more than the aggregate of feelings and ideas actual and nascent, which then exists. . . . This composite psychical state which excites the action, is at the same time the ego which is said to will the action. Naturally enough, then, the subject of such psychical changes says that he wills the action; since, psychically considered, he is at that moment nothing more than the composite state of consciousness by which the action is excited. But to say that the performance of the action is, therefore, the result of his free will, is to say that he determines the cohesions of the psychical states

1 Psychology, vol. i. p. 500. 
which arouse the action; and as these psychical states constitute himself at that moment, this is to say that these psychical states determine their own cohesions, which is absurd. Their cohesions have been determined by experiences-the greater part of them, constituting what we call his natural character, by the experiences of antecedent organisms; and the rest by his own experience. The changes which at each moment take place in his consciousness, and among others those which he is said to will, are produced by this infinitude of previous experiences registered in his nervous structure, co-operating with the immediate impressions on his senses : the effects of these combined factors being in every case qualified by the physical state, general or local, of his organism.'

Our doctrine is that the will indeed necessarily follows the stronger motive, but that the soul has, on certain occasions, the power of intensifying one motive at will, and so making that motive, for the time, the stronger. As Dr. Carpenter has justly observed, much of the mind's work is done by its ' automatic faculties,' but 'their direction is given by the Will, in virtue of its power of intensifying any idea or feeling that is actually present to consciousness, by fixing the attention upon it.' Asserting, as we do, the substantial and persistent Ego, we have no hesitation in affirming that that Ego occasionally does 'determine the cohesions of the psychical states which arouse' an action, and, at. the same time, in denying 'that these psychical states determine their own cohesions.' Mr. Spencer's error lies in not distinguishing between perceptions and emotional states which cannot but produce an effect in direct proportion to their strength, and that faculty of will which our consciousness tells us is not, when in act, a mere impotence arising from incomplete adjustment, but a conscious exertion of power adding to the strength of such emotional states or such perceptions, as may be selected for intensification. But the want in Mr. Spencer's mind of any perception of true morality is so complete that he looks upon the absence of moral freedom as a positive gain. He says :- 
'I will only further say that freedom of the will, did it exist, would be at variance with the beneficent necessity displayed in the evolution of the correspondence between the organism and the environment. . . Were the inner relations partly determined by some other agency, the harmony at any moment existing would be disturbed, and the advance to a higher harmony impeded. There would be a retardation of that grand progress which is bearing Humanity onwards to a higher intelligence and a nobler character.' 1

In blaming Mr. Spencer for this passage, we should protest against being charged with the absurdity of denying merit and beauty to spontaneous acts of voluntary adhesion to good. Such acts may be highly meritorious, and at the same time eminently free. All we mean is that for an act to be 'moral,' the doer of it must directly or indirectly be moved by the idea of 'right' present to his mind then or antecedently, so as to have become mentally habitual. ${ }^{2}$ Such habitual actions may be eminently 'free,' since freedom consists in the unhindered power of following the dictates of intelligence concerning what is best and most desirable. In proportion as less worthy motives have more power over us, just so far are we less free.

It would be a superfluous task here to expatiate upon the defective morality of a philosophy which denies to man's will any more power of choice than a fragment of paper thrown into a furnace has a choice concerning its ignition. But Mr. Spencer's moral system is even yet more profoundly defective, as it denies any objective distinction between right and wrong in any being, whether men are or are not responsible for their actions. According to our author, the laws of Nature are ultimately reducible to one force not necessarily moral, and therefore all laws and all actions must be, in ultimate analysis, equally moral or equally immoral. Every action whatever is, according to him, a mode of the Unknowable, and the stab of the assassin and the traffic of

${ }^{1}$ Psychology, vol. ii. p. 503.

${ }^{2}$ See ante, pp. 49 and 96. 
the courtesan are as much the necessary results and outcome of that ultimate principle as are the charity of a Howard and the self-devotion of 'Marseilles' good Bishop.'

The prevalence of such a philosophy then is no mere question of speculative interest, but is one of the highest practical importance. No mistake can be greater than that of supposing that philosophy is but a mental luxury for the few. The many become rapidly subjected to its influence. As explicitly declared and consciously pursued, metaphysics may indeed be a luxury; but an implicit, unconscious philosophy possesses the mind and influences the conduct of every peasant. No efforts, then, can well be more practical than those directed against metaphysical error, for philosophical doctrines filter down from the cultured few to the lowest social strata. Such doctrines, for good or ill, come to be, as it were, the very marrow of the bones first of a special school - then of a general society-ultimately of a nation.

At a period when calamitous social and political changes are urged upon us with the reckless but pertinacious zeal of democratic passion, earnestness of defence is a necessity of political existence. But what earnestness is to be expected from men imbued with the conviction, not only that their wills are utterly powerless, but with the deliberate persuasion that actions the most opposed and all political results are in the last analysis of equal worth as but divergent actions of one common force, and equally manifestations of the Unknown and Unknowable? Utility is not of course our direct object of pursuit when we investigate metaphysical truth, but it may reasonably intensify our efforts. If any system, in addition to being philosophically false, has social consequences which are manifestly evil in the highest degree, then surely these consequences peremptorily call upon us not to regard such a system with idle indifference, but to examine it with a keen and searching scrutiny. 
Before summarising the results of our considerations concerning the two points to which we have specially directed attention, it will, we think, be desirable to refer to one or two additional matters. First, then, it is nothing less than wonderful to note how completely Mr. Spencer ignores all the highest faculties of the soul. We have the most ingenious and interesting constructions of sensible perceptions of increasing degrees of complexity wrought out with abundance of illustration and a facility of research truly admirable. But what is the outcome? We feel indeed we have an insight into the power of mere sensation and the consequent faculties of brutes, such as we never had before, as also into the materials of our own thoughts; but we have no increased knowledge of our own intelligence itself. Our cat's mind is indeed made clear to us, but not our own. Those supreme conceptions and perceptions of our minds - Truth and Goodness-reflexly contemplated as Truth and Goodness, are simply passed over. Even the same thing must be said of 'relation.' The relativity of our knowledge is indeed a constant theme, and the 'relativity of feelings' and 'of relations' occupies, as before said, two chapters. ${ }^{1}$ Yet of our perceptions of relations as relations, we have not one word.

It is easy work to account for the evolution of the intellect of a Leibnitz from the physical faculties of an oyster, if the gulf, which separates direct sensible perceptions of particular phenomena from reflex intellectual apprehensions of general conceptions, be quietly ignored. This evolutionary process is treated of in the third part, ${ }^{2}$ and in its first three chapters we find the same assumption that pervades $\mathrm{Mr}$. Spencer's Principles of Biology. The assumption is that whenever the structures of animals and the actions such structures perform correspond with the environment (i.e. with

1 Psychology, chapters iii. and iv. in second part of vol. i.

${ }^{2}$ Tbid., vol. i. p. 291. 
the surrounding conditions), such structures must be due to such environment. But there is not even an attempt to show how the environment produces such structures, nor any proof that it does so produce them.

Mr. Spencer, however, not only evolves the intellect from sensation, but he evolves the various special senses from a common root, i.e. from slight nervous shocks. He says: ${ }^{1}$ 'There is reason to believe that the susceptibilities to odours, colours, and sounds arise by degrees out of that irritability which animal tissue, in its lowest forms, possesses.' Now, there is a certain ambiguity in the phrase 'out of,' as here employed. Many who would be willing enough to accept it with the signification 'from amongst' would utterly deny it in the sense of 'originating from.' For how can a smell, a colour, or a sound, be a modification of touch, however they may be conditioned by some form of touching-whether through ethereal undulations or what not? As Aristotle pointed out ${ }^{2}$ two thousand years ago, the special aptitudes of the several special senses must be innate before the least particle of such special senses become actual. And what must be asserted of sense may be declared as unhesitatingly of intellect. The special faculty of apprehending truth and goodness must be innate before the expressions 'true' and ' good' can in any way be made use of.

The absence of an adequately refined analysis is amusingly illustrated by the following sentence: ${ }^{3}$ "The ability to discriminate between organic and inorganic matter appears to be possessed in some degree even by the simplest animals.' In a certain sense this is most true; but such a form of expression would lend itself to a confusion between the sorting faculty of the apertures of a sieve and the sorting faculty of the man who employs it for sorting.

1 Psychology, vol. i. p. 304.

3 Psychology, vol. i. p. 307.

2 De Anima, book ii. 
This is not the place in which to examine, seriatim, the facts adduced by Mr. Spencer as exemplifications of intellectual evolution (to do so would require a volume at the least), but the effect upon our minds of reading these chapters has been to bring home to us with a force we never felt before how man is the one only intellectual animal 'looking before and after.' Moreover, though Mr. Spencer is a master in biology, all his facts are not always accurate. For example, he has, we think, made a slight oversight in the following passage. Speaking of the order containing Man and Apes, he says: 'The prehensile and manipulatory powers of the lower kinds are as inferior as are their mental powers. On ascending to the very intelligent anthropoid apes, we find the hands so modified as to admit of more complete opposition of the thumb and fingers.' Now, it is notorious that in the American apes the thumb is very imperfectly opposable, bending round about in the same place with the four fingers. Nevertheless, it is the common ring-tailed American apes or Sapajous (Cebus) which are habitually selected by itinerant Italians as the best adapted, by their psychical powers, for the acquisition of numerous and complicated tricks.

Were it not the case, as we have elsewhere ${ }^{1}$ pointed out, that we can, by means of language, draw a sharp line between rational and irrational animals, it would none the less be exceedingly unreasonable to deny the existence of an absolute distinction, though unable to clearly point it out. The animal and vegetable kingdoms have different natures, although we are unable satisfactorily to discriminate between the lowest forms of both.

When Mr. Spencer, in his Special Analysis, ${ }^{2}$ passes to a cousideration of reasoning, we have again to complain of a total elusion of the main question. We have elaborate ex-

${ }^{1}$ See ante, p. 43 ; and below, p. 182.

VOL. II.

${ }^{2}$ Psychology, vol. ii. part vi. 
positions of mathematical processes, but, as every one knows, such processes can be carried on by a mere machine. Mr. Spencer explains reasoning by considering only its lower kinds. The apprehension of truths as 'true,' of related things as related, he altogether ignores. Comparisons of relations are no doubt the materials of our reasoning - the means of which we make use-just as the intelligence makes use of sensible perceptions. Thus the highest and most important truth is neglected by our author, and attention directed exclusively to subordinate considerations.

We have lately heard much concerning the inability of certain savages to count more than five, or even three; and this fact has been advanced, with surprising shallowness, as an indication of transition from the psychical powers of brutes to the intelligence of man. But the slightest reflection is enough to show that the real gulf lies between the animal able to count two and the animal not able to count at all. The difference between being able to count two and having the integral calculus at one's fingers' ends is but a difference of degree. That between the process of counting two consciously, and an automatic quantitative segregation of objects, is a difference of kind. We have not the slightest difficulty $\mathrm{n}$ conceiving that a mere irrational ape might be created with its nervous ganglia and nerve fibres so connected as to turn out quadratic equations or to solve all the problems of Euclid with ease and facility. But such a creature would of course have no rational knowledge of the action he performed -no intellectual apprehension of his own psychical processes, or of problems and equations as problems and equations.

We may now attempt to summarise the results of such an examination of Mr. Spencer's philosophy as we have found compatible with our limits.

It seems to us that that philosophy, in spite of the genius of its expositor, possesses the following grave defects :- 
1. It fails to account for or harmonise with the dicta of consciousness as to the substantiality and persistence of the Ego.

2. It fails correctly to interpret the ultimate and fundamental declarations of consciousness as to necessary truth.

3. It denies the validity of that power of intensifying a motive by a voluntary act of selective attention of which power our own minds are conscious.

4. It does not (as put forward by himself) accept as valid the principle of contradiction, deprived of which our intellectual state becomes necessarily chaotic.

5. It negatives the declarations of idealist philosophers upon grounds which would justify the popular beliefs as to objectivity, and yet it denies to such beliefs all truth and reality.

6. It makes no essential distinction between the selfconscious intellect of man, manifested by a language expressing general conceptions, and the acquisition of sensible perceptions, as cognised by the sentient faculties of animals which are capable of expressing themselves by emotional signs only.

7. It takes no cognisance of our perceptions of truth, goodness, and beauty, as such, nor of our apprehension of the relatedness of relations.

8. It is absolutely fatal to every germ of morality.

9. It entirely negatives every form of religion.

10. It absolutely stultifies itself by proclaiming its own untruth, as included in its assertion that all our knowledge is but phenomenal and relative.

The theory of Evolution is of the very essence of Mr. Spencer's philosophy. Seeing, then, the widespread acceptance of the evolutionary theory, it may well be asked, Is there any necessary connection between that theory and $\mathrm{Mr}$. Spencer's philosophy? Do such consequences necessarily 
follow from that theory, however understood, or are they confined to the Spencerian and Darwinian forms of it?

It is, indeed, certain that any view of Evolution which should deny every distinction of kind between the mind of man and the psychical faculties of brutes would necessarily involve all the consequences here deprecated. But no such bar exists to the acceptance of Evolution as applied to the ' unfolding,' from potential into real existence, of constantly new forms of animals and plants. Even the actualisation (upon the occurrence of the requisite conditions) of latent life and sentiency in inorganic matter-so far as such life and sentiency be conceived of as depending upon and consequently united with material substance-may be affirmed without involving the results objected to by us. Such a theory of Evolution perfectly harmonises with the presence in man of that substantial and persistent soul which, as we have seen, the voice of consciousness agrees with those of reason and volition in demanding. If the existence of that distinct intellectual principle in man be conceded, then all the objections above given fall to the ground. Such a theory-

1. Accounts for and harmonises with the dicta of consciousness as to the Ego.

2. It readily accepts the declarations of reason as to ultimate and necessary truths.

3. It asserts that power of election which our reason and perception of responsibility make known to us.

4. It, of course, fully accepts the principle of contradiction, and thereby induces order into our intellectual cognitions.

5. It accords with the teaching of common-sense without being bound down within its limits.

6. It establishes the distinction between reason and instinct, and between language and emotional expressions.

7. It takes cognisances of our highest perceptions, including those of truth, goodness, and beauty as such. 
8. It supports and enforces moral teaching.

9. It harmonises with the declarations of religion, both natural and revealed.

10. It asserts its own truth in affirming the validity of our primary intentions.

What, then, is the motive for rejecting a single theory which accords with the facts of experience, co-ordinates and explains them, and for accepting one so laboured yet so inadequate as the one here criticised? It is much to be feared that with many the objection lies in the last point but one enumerated by us in its favour. The sting lies in the fact of its harmony with religion. A passionate hatred of religion, however discreetly or astutely veiled, lies at the bottom of much of the popular metaphysical teaching now in vogue. Delenda est Carthago! No system is to be tolerated which will lead men to accept a personal God, moral responsibility, and a future state of rewards and punishments. Let these unwelcome truths be once eliminated, and no system is deemed undeserving of a candid, if not a sympathetic, consideration, and, coteris paribus, that system which excludes them the most efficaciously becomes the most acceptable.

Our appeal, however, is not to religion but to reason, not to authority but to intelligence, not to any dogmatic system, but to the pure unadulterated, and unprejudiced human intellect if happly anywhere it may be obtained for our use. By that we are prepared to stand or fall.

In these days of theological and anti-theological strife it would be vain to look for an unprejudiced metaphysical teacher. To find such we must revert to pre-Christian times, and the best example that can be adduced of pure, unprejudiced, and yet learned and cultivated human reason, is furnished by the mind of Aristotle. It is a grave misfortune that philosophy at Oxford should no longer be repre- 
sented by the genius of Aristotle, but by a motley crew of incongruous writers of yesterday, from Hegel to Mill and Spencer.

There are many signs that we are now on the eve of a philosophic revival which will once more bring into vogue the strangely overlooked or misunderstood peripatetic system. To the actual commencement of such a renaissance Ueberweg bore witness ere he died, and more recently we have been assured of its existence by no less qualified a witness than Professor Brentano, of Würzburg. Paradoxical as it may at first appear, it is not impossible to regard $\mathrm{Mr}$. Spencer's system, when examined from a certain standpoint, as nothing less than the morning star of such a day of revival in England. His very inconsistencies, and the lacunæ of his system, indirectly tend to occasion the more rapid advent of that renaissance by the imperative demand they make for corrective and complementary truths.

In philosophy, we find Mr. Spencer asserting or allowing that the ultimate and fundamental dicta of our intellectual faculties must be accepted as objectively true, and that our spontaneous perception of a real external world is a valid intuition. Also, in spite of his seeming denial of the substantial Ego, he admits that we are compelled to think that something 'persists, in spite of all changes,' and he 'maintains the unity of the aggregate in spite of all efforts to divide it.' Even as regards recognition of time relations, he admits' 1 that these are 'scarcely more than foreshadowed among the higher animals'; and as to acts in anticipation of future events, he allows ${ }^{2}$ that 'only when we come to the human race, are correspondences of this degree of speciality exhibited with distinctness and frequency.' Mr. Spencer's arguments against realism fail indeed, but they do so mainly because he does not distinguish between 'sensible perception' and 'intellectual apprehension.'

1 Vol. i. p. 326.

2 Op. cit., p. 333. 
It is the presence of the positive elements in Mr. Spencer's philosophy which makes us hopeful as to some of its results in one direction, while deploring its fatal effects generally. The truths he admits, or explicitly maintains, are pregnant with far-reaching consequences which may result in strange transformations. Indeed, we are not sure but that the judicious application of a little 'transverse vibration' to Mr. Spencer's system might convert it, rapidly and without violence, into an 'allotropic state,' in which its conspicuous characters would be startlingly diverse from those that it exhibits at present. Parallel statements may be made respecting Mr. Spencer's theology. Although his system is most thoroughly and completely pantheistic, he every now and then makes admissions or assertions of a much more positive character. Thus he refers to an 'ultimate cause,' most mysterious and most incomprehensible, to which he gives the self-contradictory name ' the Unknowable.' To this supreme and inscrutable Being we must assign no limits whatever, ${ }^{1}$ and (most important of all) if $\mathrm{Mr}$. Spencer declines to affirm 'personality' of this Being, it is because ${ }^{2}$ any conception we can form of 'personality' is inadequate and below, rather than above, the unspeakable reality.

Considerations such as these lend an interest to $\mathrm{Mr}$. Spencer's writings yet deeper than their own merits, many and great though they be, would justify. His system is not a final resting-place, but a halting-station in the philosopher's progress, and one at which several roads meet and diverge. Spencerism, like Lockism, may form a landmark in the history of Philosophy. Like Locke, Mr. Spencer has enunciated an ambiguous system-one capable of two distinct interpretations. It has been the fate of Locke to have been accepted and developed mainly according to the negative and irrational interpretation. It may be that it is $\mathrm{Mr}$.

1 First Principles, p. 99.

2 Op. cit., p. 109. 
Spencer's happier lot to be accepted and developed mainly according to the more positive of his enunciations, and in support of the validity of human reason; and thus, as an unconscious herald of the dawn, he may come hereafter to occupy an important position among the supporters of true Philosophy. 


\section{PREHISTORIC AND SAVAGE MAN. ${ }^{1}$}

THAT ' the proper study of mankind is man'! is a truth which is brought home to us with peculiar force by the circumstances of our own time. For what is the main end of all our pursuit of knowledge but to obtain sure rules to guide our conduct; and what knowledge can be so efficient for this purpose as a correct appreciation of man's true place in nature, the objects of his legitimate hope or prudent dread, and the laws which govern human progress and human retrogression?

But some of my hearers may perhaps object that a knowledge of the civilised world and of the epochs reckoned as 'historical' are all that we practically require, and that a consideration of prehistoric relics and of the barbarous customs of existing savages (however curious or interesting), can but be of small if of any real utility to us.

Such objectors must be little familiar with the course of recent speculative thought, or they can but very inadequately appreciate its far-reaching consequences. I have myself no hesitation in saying that in our own day Anthropology-the science of man-is the most practically important of all the sciences, and that now, far more forcibly than in the days of Terence, one should say-

'Homo sum, et niliil humanum a me alienum puto.'

Moreover, such objectors cannot have reflected that nothing is well known to us unless we know, not only what

${ }^{1}$ An address delivered at the opening of the Loan Exhibition of Prehistoric Antiquities and Ethnography, etc., Liverpool. 
it is, but how it becomes what it is, and what are its essential powers and capacities. No plant is well known to us unless we know not only its foliage and flower but its very germ, the modes and conditions of its development, the good effects which cultivation may produce, and the deformities and diseases which adverse circumstances may occasion.

Applying this consideration to ourselves, the great importance of the sciences which this exhibition is intended to illustrate becomes manifest.

And now let me congratulate you on the exhibition itself -on the happy results obtained by those gentlemen to whose exertions our presence here is due. In the rooms opposite to us are specimens of human industry from the most diverse races and the most varied climes, illustrating the different degrees of more or less striking imperfection in which our fellow-men now exist. We have specimens of their pottery, their textile fabrics, their musical instruments, their weapons, and the objects of their worship or superstitious reverence-specimens collected, some from races still numerous, but others specially interesting as belonging to tribes rapidly diminishing in number and destined too soon to be lost to us for ever. Moreover, besides these illustrations of the world as it is, you have also a most valuable collection of objects which may carry us back in imagination to an epoch so distant that of its antiquity we have as yet no approximatively accurate measures in years.

This fine collection, the greatest and best, I believe, which has ever been made in this country out of London, is a just subject of congratulation, and I regret that the modesty of the gentlemen who have exerted themselves to get it together forbids me to mention their names. There is one name, however, which I will mention, the name of a venerable gentleman whose public spirit is well known and universally esteemed in Liverpool. I mean Mr. Mayer, to whose zeal 
and liberality this city owes so many of the antiquities of which it is possessed.

Amongst the gentlemen who have kindly lent valuable objects for exhibition I may mention Mr. W. J. A. Grant, to whom we are indebted for Eskimo articles-objects of especial value and interest, as I shall have occasion to mention shortly. To Dr. J. L. Palmer we are also indebted for similar contributions, and for some rare sketches from that wonderful Easter Island, the mysteries of which he is perhaps better qualified by his knowledge to explain than any one else. Mr. Henry C. Stephens has also contributed some very remarkable fetish figures from New Zealand. To the Rev. W. G. Lawes, missionary in New Guinea, our thanks are especially due. Also several of the Liverpool West African merchants have contributed a large group of West Coast objects. Time does not permit me to enumerate all the kind lenders, but the names of all are given in our catalogue.

And now, after these preliminary remarks on the collection itself, I will venture to direct the attention of my hearers to certain facts and theories a knowledge of which is necessary for its profitable examination and study.

No doubt a large number of my hearers, perhaps the majority of those present, are already well acquainted with them, but I feel I have no right to suppose that such is the case universally, and I therefore crave the indulgence of one portion of my audience while, for the sake of the other, I briefly state a few very elementary facts and generally admitted views.

As I have already indicated, this exhibition illustrates on the one hand the more or less ancient condition of at least a considerable portion of mankind, while on the other it tends to make known the state in which other portions exist to-day. It illustrates, that is to say, the sciences of Prehistoric Archoeology, Ethnography, and Ethnology. 
The science of Prehistoric Archæology is eminently a science of the latter half of the nineteenth century. Its birth may be dated from the year 1847, when M. Boucher de Perthes published ${ }^{1}$ his description of flint implements found in the gravel in the valley of the Somme near Abbeville. Anticipations of such a discovery had however existed, and attention had before several times been drawn to evidences of great human antiquity-evidences which had, however, been persistently disregarded owing to the strength of the prejudice which existed in favour of the belief that man had inhabited the earth but for a very few thousand years. Indeed, even at the commencement of the present century, Mr. John Frere communicated to the Society of Antiquaries ${ }^{2}$ a clear description of flint tools (like those since found near Amiens) which were discovered in Suffolk.

Much later, in the year 1832, human relics were discovered by the Rev. Mr. M'Enery in Kent's Hole, near Torquay, and by Dr. Schmerling in caverns near Liége. Nevertheless, before the eventful discovery of M. Boucher de Perthes, these and all other attempts to force on reluctant hearers, man's claim to a yet unaccepted antiquity were alike fruitless. As soon, however, as that discovery had obtained a serious and more or less unprejudiced attention to the subject, fresh evidence was rapidly accumulated from very varied sources. Not only from caves and gravel beds, but from the remains of ancient lake dwellings in Switzerland, from shell mounds and refuse heaps in the Danish islands; and not from Europe alone but also from Asia (including India and Japan), and from the Americas,-_from all sides,overwhelming evidence forced the most incredulous to yield assent to the widespread existence of the remains of Prehistoric Man.

1 In the first volume of his Antiquités Celtiques.

2 Frere's Archoologia for 1800, vol. xiii. p. 206. 
But to what past epoch can man's existence be now shown to have extended? As to this there are still wide differences of opinion amongst experts. The evidences of the past history of this planet are the various fossils which are enclosed in the several strata, the relative ages of which are shown by their relative positions - the uppermost being the most recent. These epochs, I may perhaps be permitted to remind you, are reckoned as three in number, the primary or most ancient, the secondary or intermediate, and the tertiary or most recent. It is the last of these only with which we can have any concern. The tertiary epoch is that during which the various strata have been deposited which lie above the chalk, and these strata are subdivided into three sets, called respectively eocene, miocene, and pleiocene, because the first saw, as it were, the dawn, and the third the fulness, of various forms of animal life closely resembling those which still survive. The pleiocene period really continues now, but for convenience-sake the most recent portion of it is distinguished as post-tertiary (or pleistocene and recent), including the deposits of rivers and those found in caverns.

To which of these deposits then can we trace evidences of man's existence? No one, so far as I know, has yet affirmed that there is any evidence anterior to certain remains which have been thought to be of the Miocene period. These remains consist of some splinters of flint, and a notched fragment of a rib, found by the Abbé Bourgeois at Thenay, in France. These data, however, are not generally regarded as satisfactory or sufficient, and I believe the great majority of experts decline as yet to admit the existence of Miocene man. Man, zoologically speaking, is one of the great groups of creatures which suckle their young, and are therefore called mammals. Now the mammals which existed on the earth, so far as we know, in Miocene times have, although very rich in number, entirely passed away, and it is not deemed 
likely that man should have alone survived had he then existed.

Passing on, next, to Pleiocene times, we find even there but insufficient evidence of man's presence. It is true that a human skull and flint implements have been found at Olmo, near Arezzo, in Italy, by Professor Cocchi, in deposits deemed Pleiocene, but the evidence as to the true position in which these objects were found is far from satisfactory, and the existence also of a fragment of pottery seems conclusively to point to a much later date, as does the form of the flint implement itself, which is of the more refined and not of the ruder kind of make. We may, I think, say then that there is no good evidence for the existence of even Pleiocene man. This negative evidence is again supported by the fact that almost, though not quite all, the species of mammalia which lived in Pleiocene times have disappeared from the earth. Anyhow man, however many centuries he may have seen, is still geologically recent. But the Mammalian population, which was undoubtedly contemporary with early man, existed before the glacial epoch, and it appears to me most probable that man was pre-glacial also.

The remains of prehistoric man, yet unacquainted with the use of metals, are classed in two groups, according to the form of the implements he made. The older kind, roughly though skilfully formed, are called Palæolithic, and the makers are known as Palæolithic man. The newer kind, carefully ground and polished, are called Neolithic, and their makers are known as Neolithic man.

The Palæolithic men (the oldest men as yet certainly known by their works) lived here under circumstances widely different from our own. In their day the sea rolled over what is now Norfolk and Suffolk; England and Ireland were physically one, and were continuous with the mainland of Europe. Not only had he with his rough weapons to 
defend himself against wolves and wild boars, but against hyænas, brown and grizzly bears, and enormous lions. In turn he hunted and preyed upon abundant game such as now would be sought in vain even in the teeming plains of South Africa. Besides horses and stags, the Irish elk, bisons and musk oxen, the hippopotamus, two kinds of elephants, and three kinds of rhinoceros, haunted our woods, rivers, and plains. Deeply interesting is the question-What was man in this early stage? Apparently ignorant of pottery and of spinning, Palæolithic man was nevertheless thoroughly human. Admitting that he was not even then everywhere or always in the same condition, there is yet no evidence that he was ever or anywhere in a condition below that of savage man to-day, while there is abundant evidence that even then he was often far in advance of many of our existing wild tribes. The Palæolithic men, known as the cavedwellers, shot birds with bows and arrows, and stalked or trapped other game, and seem to have practised fishing. Not only did they wear necklaces and, as appears, amulets, but they could sew, and even wore gloves. Their food was roasted, or cooked on hot stones, and if they had not forks, they had at least marrow-spoons. But far more remarkable is their artistic faculty. We owe to it the only authentic representation of the mammoth-or extinct elephant(scratched by them upon one of its own bones), and many drawings have been most fortunately preserved of other animals and of their mode of hunting, including horsehunting, that animal seeming to have been known to them merely as game. Not only, too, did they draw freely, but sculpture also existed in an incipient state amongst them.

When did this race exist? and do they anywhere survive to-day? To the first question no satisfactory answer can yet be given in years; to the second the answer has been given that they probably survive as the Eskimo. 
The Eskimo are a people possessing many peculiarities, and it is very interesting to note that some of these exaggerate the characters of the highest races of mankind. The pelvis differs from the European pelvis in an opposite direction to that by which the negro pelvis differs from the European, and the same is the case with the proportions of the limbs, while the skulls of the Esquimaux have the narrowest nasal aperture of all races, being in this respect the very opposite of the Australians. They have also large brains. They have the very same habit of depicting their hunts and game as had the Palæolithic men, and like them they sew, using sinews as their thread.

Widely different was the condition of the races which succeeded these earliest-known flint-makers. When the polished stone makers-the Neolithic men-inhabited Britain, Ireland was separated off from it by the sea, though Anglesea and the Isle of Wight formed parts of the English mainland, which was no longer the home of the great beasts before mentioned, though the brown and grizzly bears, wild boars, wild cats, and the Irish elk still lingered, accompanied also by the reindeer.

Our Neolithic ancestors seem to have come into Europe from the east, bringing with them domestic cattle (the dog, hog, ox, goat, and sheep), with wheat, barley, millet, peas, poppies, flax, apples, and pears, together with a knowledge of the domestic arts of spinning, weaving, pottery-making, the formation of carefully polished stone implements, with the use of canoes, and the practice of trading, which would account for the presence of jade from China. The Neolithic age in Northern Europe probably existed down into a period which is completely historical as regards its southern portion, and the Neolithic men probably still live amongst us in our Celtic, and certainly in our Iberian, races.

The next ages were those wherein metal was used, first 
bronze, then iron. The bronze age in Europe, which seems, like its predecessor, to have come in as a wave of migration from the east, introduced a yet higher development of civilisation leading us up to the distinctly historical period, lasting as it did in the northern peninsula till 100 A.D. To the bronze men succeeded others acquainted with the use of iron, and such were the inhabitants of this country when Julius Cæsar invaded it. I turn now to the other science which this collection is designed to illustrate-the science of Ethnography.

The inquiry into the conditions of life of different races and nations is one which dates back to the time of Herodotus, and no doubt antecedently formed part of the lore of ancient Egypt. But a true science of the kind can only be said to date from the publication of Blumenbach's inaugural thesis on the Varieties of Man, in 1775. The first Ethnographical Society was that founded at Paris, in the year 1800, and styled 'Société des observateurs de l'homme,' but it only lasted a few years.

An analogous society, but with a philanthropic object (also very short-lived), was instituted in London in 1838, while the Société Ethnologique de Paris was founded in 1839. The English Ethnological Society met for the first time in London on January 2nd, 1844. A Société Anthropologique was started in Paris, in 1859, by M. Broca. An English Anthropological Society was set going in London in 1863, but in January 1871 it united with the pre-existing Ethnological Society, and the united societies still exist under the title of the Anthropological Institute of Great Britain and Ireland.

The careful observations of successful explorers rapidly added to our stock of information, and great is our debt to such earlier travellers as Bruce, Levaillant, Pallas Bougainville, La Vermie, and our own noble countryman, Captain Cook.

VOL. II. 
In perusing the ever fresh narrative of Captain Cook, it is, I think, hardly possible to avoid a certain feeling of regret that no lands any longer remain to reward the explorer, such as again and again excited his astonishment and admiration. These earlier efforts have been followed by explorations, undertaken with increasing care as time has narrowed the field of discovery.

But much as has been done in the science, very much still remains undone, which is the more to be regretted, both on account of the perishing nature of the matter under investigation. and of its great importance. Very desirable is it that we should know much more than we do know of the history of each race, that we might be able to determine what social phenomena are due to the action of isolation and degradation, and what to spontaneous and independent advance.

Great is my desire, great I am sure is the hope of the promoters and encouragers of this exhibition, that further steps in advance may date from this day, and from the increased interest and the augmented zeal for ethnography which the study of the objects here brought together may call forth in this great city so important for its power to. aid us.

But, as I said at the beginning of this address, the great. end of human science is to enable us, through a knowledge of truth, to act judiciously; and (as I added) no knowledge can be so conducive to rational conduct as a correct appreciation of human nature.

Ethnography has become the very important science it now is, because through it we must investigate one of the most important branches of the inquiry 'What is man?' I feel it incumbent on me to say a few words as to the bearing of our sciences on this question, because a superficial consideration of such facts as those before us evidently may lead, 
since it has led, to what I am persuaded are very mistaken results. I should ill perform the honourable duty with which you have intrusted me, if I did not point out to the best of my power what I believe to be the true lessons which scientific facts, considered without prejudice, teach us as to this important question. In this inquiry it is especially necessary to try and guard against the unconscious action of our desires or sentiments upon our reason. There is no appeal from the facts of science and from inferences thence logically drawn, and every attempt to ignore the former or elude the latter in deference to any traditional belief which may be threatened, or to support any theory which may have captivated our fancy, must be carefully and scrupulously avoided.

But we must also be very careful that what we take to be facts are indeed such. We must be careful not to attach undue importance to differences which strike the eye, neglecting essential resemblances which are more recondite.

Even in our intercourse with our fellow-countrymen, we are sometines tempted to despise an intellect which manifests itself by uncouth gestures and coarse speech wherein the rules of grammar and correct pronunciation are violated, and yet that intellect may be quite as good as ours. I have been myself more than once surprised in intercourse with peasants, to find how correct was their appreciation even of questions of philosophy when once I had got over the difficulties arising simply from our different modes of expressing similar ideas.

If such misapprehensions may arise even in a country like this, how much more must we be liable to error in estimating the true nature of men so very widely different from ourselves in all that strikes the senses and is calculated to cause astonishment, as are the wild tribes which inhabit the remoter regions of the earth! Here surely extreme caution 
is needed to avoid injustice and consequent error-error in answering the grave question, What is man? Is he to be regarded but as a part and product of the organic world, and essentially one in his nature with the brutes, or does his existence indicate a break in the continuity of nature? Two beliefs as to man's origin are, as you know, now in vigorous conflict.

I. According to one of these beliefs man, with all his intellectual faculties, has arisen by a process of gradual change from an ape-like ancestor.

II. According to the other belief, man's origin is due to some sudden change in the course of evolution, which change has resulted in the introduction into the world of an intellectual principle different in kind, and not only in degree, from anything existing in the merely animal world.

Let us endeavour to see which of these beliefs is supported by the science of ethnography, and let us, if you please, assume the truth of the theory that all other animals have been evolved by a process of natural generation-a theory which commends itself to my own mind.

Starting with this assumption, we are met at once, on our course to explore the question of man's origin, by the obvious truth that man's body has a close resemblance to that of a beast, and, above all, to that of an ape, and it is urged that, if these animals have been evolved one from another, then there is an almost overwhelming probability that man has been similarly evolved. It is also further urged that prehistoric Archæology proves that man has existed in a condition less removed from that of the highest brute animals than from that of the Greeks of the time of Pericles and of that of the members of our own learned societies. Finally, it is contended by some persons that ethnography supplies us with examples of men still surviving in so low a condition as almost to fill up any gap which 
may seem to require filling. For tribes of men have been found naked and not ashamed, dwelling in caves or forests, almost as devoid of artificial weapons as are some animals, uttering only uncouth guttural sounds, which seem hardly human, and so cruel and bloodthirsty as to appear devoid of every germ of morality. Such beings may seem to be not far removed from those 'missing-links' which are required to directly connect the human species with the lower animals.

In reply to all this I may first observe, in passing, that few Evolutionists now maintain that existing savages are the survivors of primitive mankind. Even Mr. Herbert Spencer says : 'Probably most, if not all, of them had ancestors in higher states.' With respect to the degradation of savage races I refer with pleasure to a remarkable address delivered in 1873 , before the Literary and Philosophical Society of this city, by Mr. Albert J. Mott, but I shall not enter on this matter myself, as it is one quite beside the main question. That question is-Are there any indisputable and deeply important characters by which all tribes of men fundamentally agree with the Greeks of the time of Pericles, and with the members of our own learned societies, and altogether differ from even the highest brutes? I maintain that the gift of rational speech is such a character, and to this may be added the power of moral perception. No tribe has ever yet been discovered which has not such language, and there is abundant evidence that even the lowest of them can form judgments as to justice and injustice-in other words, that they are capable of ethical perception. Hence arises a very plain argument in favour of the unity and essential distinctness of our human nature. But this argument is met by three assertions which demand careful consideration. They are-(1) Mere animals also have language; (2) Man's brute ancestors had themselves language, and this begot

1 Principles of Sociology, vol. i. p. 106. 
reason; (3) The higher animals have a moral nature. Let us consider these seriatim, and for their consideration I bespeak your indulgent attention on account of the importance of the questions we are occupied with. (1) Mere animals have language. This assertion is ambiguous. Mere animals have or they have not 'language,' according to the sense we give to that word, which serves to denote two very different things; one being the expression of mere feelings or emotions, the other the external manifestation of thoughts. As to the former, no one would affirm that brutes have not the power of emotional expression. My assertion is that the gift of 'rational speech' is peculiar to man.

Now rational speech is evidently made up by the union of two factors - the one mental, the other corporeal-the one the idea conceived by the mind, the other the bodily action which serves to give expression to that idea. The essence of rational language is mental, the mental word; the bodily action by which that mental word is expressed externally, is but secondary. This is shown by two facts. First by the fact that the same idea may be expressed in various ways, and secondly by the fact that as the intellect in any new science evolves new ideas, new terms are invented as a sequence, not as an antecedent, to such intellectual action. But the external expression may be given in various ways, by a variety of gestures as well as by words: still, organised as we are, motions of our vocal organs are by so much the most convenient for the purpose that, practically, ideas are mainly thus expressed; and each mental word becomes embodied in its approximate oral expression-the oral word corresponding to the mental word, but yet being more or less inadequate, since we speak less perfectly than we think. Six different kinds of language may be enumerated:-

(1.) Sounds which are neither articulate nor rational, such as cries of pain. 
(2.) Sounds which are articulate but not rational, such as the talk of parrots, or of certain idiots, who will repeat without comprehending every phrase they hear.

(3.) Sounds which are rational but not articulate, such as the inarticulate ejaculations by which we sometimes express assent to or dissent from given propositions.

(4.) Sounds which are both rational and articulate, and such is ordinary human speech.

(5.) Gestures which do not answer to rational conceptions, but are merely the manifestations of emotions and feelings.

(6.) Gestures which do answer to rational conceptions, and are, therefore, 'external' but not 'oral' manifestations of the mental word.

A great deal too much stress has been laid upon the fact of articulation, for this character of speech is merely due to the breaking up of vowel sounds and consequent multiplication of distinguishable utterances; various mere animals can articulate, and it is quite conceivable that brutes might (though as a fact they do not) so associate certain sensations and gratifications with definite articulate sounds, as in a certain sense to 'speak' while remaining all the time as utterly devoid as ever of rational language. Just as a dog learns to 'beg' by associating certain gestures with 'subsequent pleasurable sensations of 'joy,' so a parrot might conceivably learn to ask for its dinner or to say, 'Open the cage door, that Poll may take a walk,' while in no way understanding either the words or the sentence thus uttered. The late lamented George Henry Lewes, strong Evolutionist as he was, clearly saw and admitted this distinction, and he says, ${ }^{1}$ in his just published posthumous work: 'The dog, although without language, may yet be taught so to connect the sound "lion" with other feelings, that on hearing it

1 Problems of Life and Mind. Third Series, Problems 2, 3, and 4, 1879. p. 473. 
shouted he too may have an image of the lion and be alarmed. But although the sound has thus become a sign for the dog, just as any other sound-rustle in the grass, thud on the ground, or growl-the sound is not for him a word, a symbol, an idea. It is not an abstract general sign. It cannot be thought.' Man alone then has rational speech, and therefore reason, of which it is the sign. Now as we see in human immaturity and infirmity, wherever intellectual activity exists, it seeks external expression by symbolsverbal, manual, or what not-the language either of voice or gesture.

It follows then that the second assertion above quoted, 'Speech begot reason,' cannot possibly be maintained. For just as some form of symbolic expression is the necessary consequence of the possession of reason by an animal frame, so it is impossible that true speech can for a moment exist without the co-existence with it of that intellectual activity of which it is the outward expression. As well might the concavities of a curved line be supposed to exist without its convexities, as the oral word be supposed to have arisen prior to that mental word which it represents. Moreover, speech requires an apprehending intelligence on the part of the hearer as well as on the part of the speaker, if it is to be more than a monologue; and we may consider it certain that speech could never have arisen had not two persons possessed the same idea at the same time.

How is language invented now? Do men give utterance to unmeaning articulate sounds and subsequently annex new ideas thus generated to them? Is not the fact, as before observed, notoriously the other way?

It is of course true that infants learn to speak words the meanings of which they do not understand; but in the first place they learn them from those who do know and who make known to them by degrees their meaning; and in the 
second place we do not know but that vague, incipient conceptions accompany the utterance of even the first spoken words. The son of a friend of mine, now a very distinguished young man, alarmed his father by the length of time he remained unable to speak, but he showed by an elaborate language of gesture that he had distinct intellectual conceptions. Deaf-mutes are a very instructive class, for they clearly exemplify how secondary is the spoken word to the mental concept.

I have desired, even at the risk of wearying you, to impress upon your attention the distinctions I have now pointed out, for without a clear apprehension of them it is a hopeless task to consider the problem of man's nature and origin; and yet, strange to say, men of great repute venture not only to attack that problem, but to widely promulgate their views, while remaining all the time in apparently contented ignorance that any such distinctions exist. Wonderful is the confusion of thought which exists on the subject of language. It is almost enough to make one despair of progress when one hears men affirm-in the face of such obvious facts as have been just adverted to-that human reason has been evolved by speech. As Wilhelm von Humboldt has declared: 'Man is man only through speech, but in order to invent it he must be already man.'

I turn now to a consideration of the third proposition (3) -The higher animals show signs of morality; and here I have to also meet the assertion that tribes of men are devoid of it.

Just as in the matter of language, so also in the question of morality, attention must be directed to a fundamental distinction.

Our moral activity consists of an intellectual perception which is generally accompanied by a certain feeling, but the essence of moral action is in the perception and consequent 
act, and not in the feeling. That it is so is plain, since the latter may be altogether absent, while no amount of feeling will make an action 'moral' if not accompanied or preceded by a perception that the action is a right one.

Yet another distinction should be noted. An action to be moral must be accompanied by a good intention, though its goodness need not, of course, be specially adverted to. This is plain, since no one would call the good nursing of a wearisome patient a 'virtuous act' if he knew that this was only done to secure a large legacy.

How little mere feeling has to do with morality any example of a victory of conscience over temptation will make plain enough. ${ }^{1} \quad$ A man may judge that he ought to renounce a tender friendship without its becoming one bit less delightful to him to continue it. More than this, let him have done so. Suppose further that he, from a conscientious regard to the just claims of one who has paramount rights, has severed such ties. In spite of his perception that he has acted rightly, his act may occasion him keen emotional suffering for years. Let us suppose that the struggling father of a family becomes aware that the property he lives on really belongs to another, and that he therefore relinquishes it. He may continue to judge that he has done a proper action, whilst tortured by the trials in which his act of justice has involved him.

By morality, then, is not meant merely a feeling of sympathy, a deference to the desires of others, or some emotional excitement tending to produce beneficial action. What is meant is an intellectual activity evinced by the expression of definite judgments passed upon certain modes of action to the effect that they are or are not good, bad, or indifferent. No preference of the interests of the tribe over self, or anger at the absence of such preference, is

${ }^{1}$ See ante, p. 50. 
moral unless there is a judgment that such preference is 'right.'

Similarly the prevalence in any tribe of practices which shock us will never suffice to prove the absence of moral perception in such tribe. Men are not necessarily devoid of morality because they draw their lines in different places from what we do. We have, then, but one question to consider-Have we reason to believe that any tribe is destitute of the faculty of moral perception? As to brute animals we willingly concede to them feelings which seem to run parallel with our feelings of guilt and shame, but no one pretends they are capable of abstract judgments as to right and wrong, of which we shall, I think, directly see even the most degraded savages are plainly capable.

Now one of the clearest ethical judgments is that as to 'justice' and 'injustice'; and by common consent the native Australians are admitted to be at about the lowest level of existing social development, while, as we have seen, the Eskimo are deemed by some to be the surviving specimens of the oldest known men. Concerning the first of these races, the Australians, Sir John Lubbock tells us :- 1

'The amount of legal revenge, if I may so call it, is often strictly regulated, even where we should least expect to find such limitations. Thus, in Australia, crimes may be compounded for by the criminal appearing and submitting himself to the ordeal of having spears thrown at him by all such persons as conceive themselves to have been aggrieved, or by permitting spears to be thrust through certain parts of his body, such as through the thigh, or the calf of the leg, or under the arm. The part which is to be pierced by a spear is fixed for all common crimes, and a native who has incurred this penalty sometimes quietly holds out his leg for the injured party to thrust his spear through! So strictly

\footnotetext{
1 Origin of Civilisation, p. 318.
} 
is the amount of punishment limited, that if in inflicting such spear-wounds, a man, either through carelessness or from any other cause, exceeded the recognised limits-if, for instance, he wounded the femoral artery-he would in his turn become liable to punishment.

'A yet stronger example of savage moral perception is also furnished us by the Greenlanders. Should a seal escape in Greenland with a hunter's javelin in it, and be killed by another Greenlander afterwards, it belongs to the former. But if after the seal is struck with a harpoon and bladder the string breaks, the hunter loses his right. If a man finds a seal dead, with a harpoon in it, he keeps the seal but returns the harpoon. Any man who finds a piece of driftwood can appropriate it by placing a stone on it, as a sign that some one has taken possession of it. No other Greenlander will then touch it.'

The inhabitants of Tierra del Fuego are, if possible, more wretched savages than the Australians, yet it is very interesting to note that even with respect to these no less a witness than Mr. Darwin himself informs us that when a certain $\mathrm{Mr}$. Bynoe shot some very young ducklings as specimens, a Fuegian declared in the most solemn manner, ' $\mathrm{O} \mathrm{Mr}$. Bynoe! much rain, snow, blow much!' And as to this declaration, Mr. Darwin tells us that the anticipated bad weather 'was evidently a retributive punishment for wasting human food,' i.e. for a transgression of the imperfect moral code recognised by the Fuegian in question.

That the language of savage tribes is capable of expressing moral conceptions will probably be contested by no one. Even Mr. Tylor observes: 'Glancing down the moral scale amongst mankind at large, we find no tribe standing at or near zero. The asserted existence of savages so low as to have no moral standard is too groundless to be discussed.' 
As far then as a posteriori evidence shows, man ever possesses the faculty of moral perception. And this $a$ posteriori evidence is but what we might expect seeing what is the evidence a priori. As already said: ${ }^{1}$ "The obvious truth that all knowledge is either certain in itself or is derived by legitimate methods from that which is so . . . is of course true of ethical knowledge. If a proposition announcing obligation require proof at all, one term of that proof must always be a proposition announcing obligation, which itself requires no proof. In other words, the general propositions which really lie at the root of any ethical system must themselves be ethical.'

This truth cuts the ground from under-renders simply impossible-the view that a judgment as to moral obligation can ever have been evolved from mere likings and dislikings, or from feelings of preference for tribal interests over individual ones.

Thus a glaring hiatus exists between man in the lowest and most degraded condition in which Ethnography reveals him to us and the pure and simple animal. That this hiatus now exists is not indeed denied, for it is so manifest it is incapable of denial.

But it is contended that it did not always exist, though the argument that it did not do so is not supported by any actual observations or by an appeal to experience, but reposes on its supposed necessity in order to make valid the theory of evolution in its entirety. But we cannot pay the price of the sacrifice of facts for the sake of even the most seductive theory.

Of the truth of that theory we may be persuaded, but of the existence of the hiatus we may be certain. If we must reject one, then must we rather reject the persuasion as to the former than the certainty as to the latter. As I said a

1 By Mr. Arthur Balfour. See ante, vol. i. p. 408. 
little time ago, not only must facts and legitimate reasons be accepted although they may conflict with a traditional belief, but they must also be accepted even though they may disaccord with some scientific theory which may have captivated the fancy.

But the theory of Evolution, as a whole, is not threatened by any contention, but only the doctrine which affirms the essential bestiality of man. As to one stage of evolution Mr. Darwin himself has said: 'There is grandeur in the view of life having been originally breathed by the Creator into a few forms or into one.' Why not then into the first human form also? If such a breach of continuity as Mr. Darwin supposes may have taken place once, why not again-above all at the first origin amongst mere animal life of an intellectual nature capable of recognising with gratitude and love that creative act to which it owed its being ?

The reluctance to recognise the existence of a break in the continuity of nature because we cannot imagine it, is but one of the many modern attempts to tie down reason within the narrow bonds of our power of imagination, and this though even in our own very act of sight we have an example of what we can neither perceive nor imagine, but which we nevertheless most certainly know.

Unless, then, I am very greatly mistaken, the arguments adduced to prove the bestiality of man seem but to bring out more clearly the essential distinction which may be drawn between him and the beasts which perish-a distinction which defies refutation and courts the most ample and searching examination. Not even an attempt has, as far as I know, yet been made to meet the arguments which I have briefly here restated against Mr. Darwin's theory of man's origin. I am strongly persuaded they cannot be met:

To these deductions of reason, the data set before us by the science of Ethnography lend very important aid, and 
this exhibition will now help to bring home to us the essential similarity of nature which underlies the conspicuous diversities of appearance presented by different members of the great human family. Thus our poor cousins of the woods and wilds, in fulfilling the end of their existence, are far from devoid of utility to us, since their testimony is of high value in supporting our claims to a more than brutal origin. The religion of Abraham and Chrysostom, the intellect of Aristotle and Newton, the art of Raphael-of Shakespeare, of Mozart, have their claims to be no mere bestial developments supported by that unconscious testimony.

These considerations, ladies and gentlemen, may well cause you to regard this exhibition not merely as one replete with objects of curiosity and interest, but as a spectacle full of deep and solemn import. And once more permit me to congratulate you on its existence here to-day, and to conclude with a practical suggestion with reference to the locality in which we have met. It is eminently fitting that such an exhibition should have its home in this great city, one of the largest shipping centres in the world, the home of a commerce which brings in its tributes from almost every race and clime. No city is better able than is Liverpool to give important aid to the science of Ethnography, nor, I am well persuaded, is there any want of generous desire on the part of its merchants to help the science to the best of their ability. I ask, then, why should a great ethnographical collection be but a transient, however attractive, feature of this city? Why should there not be a permanent local ethnographic museum attached to such a port as this? I should indeed rejoice if from this very 25th of May might be dated the setting on foot of such a project as the foundation of the Liverpool Ethnographical Gallery. Whilst the competition of foreign countries renders it daily more difficult for us to secure costly works of art, the opportunity still 
remains to us of purchasing with ease most valuable ethnographic treasures. But we have no time to lose. Tribes and races, precious relics of a former state of things, are rapidly passing away; and not only are tribes becoming extinct, but local customs and manufactures are rapidly disappearing. The Tasmanians are gone, and but poor remnants have been preserved of a race in many respects estimable as well as interesting. Not a day is to be lost if we would secure for those who are to come after us accurate notions of the world which like a dissolving view is passing away before our eyes. I feel persuaded that the merchants and merchant service of Liverpool are prepared to do their best; but if, acting on this suggestion, many objects should be brought home by their efforts to this city, I would beg them to observe one most important rule, without which their best efforts will be of little value. It is especially important that every object collected should bring with it a precise statement of the exact locality whence it came, with a note of as many other circumstances connected with its acquisition as may be obtainable. In these days to say that an object came from the South Seas or from Australia is useless. We must in each case be informed of the exact spot whence it has been brought. If this caution be borne in mind, there can be no doubt but that the men of this city may afford most valuable aid to the science of Ethnology, and that they will do so I argue from the appreciative interest and warm cordiality which have been displayed with respect to this exhibition. 


\section{ADDRESS TO THE BRITISH ASSOCIATION.}

\section{9.}

\section{BIOLOGY.}

$\mathrm{T}^{\mathrm{N}}$ responding to the honour which the authorities of the 1 British Association have conferred in nominating me to fill this chair, I have deemed it best not to occupy your very valuable time with any matter of detail at which I may happen to have worked, but rather to offer to you a few remarks on questions which seem to me to have a general biological interest.

Last year my esteemed friend, Professor Flower, called your attention to the great name of Linneus. I propose this year to refer to Linnæus's illustrious contemporary, BUFFON-not, however, in the character of a rival of Linnæus. Each was a man of genius, each did good work in his own way-work still bringing forth fruit. It must be admitted, however, that they were men of a very different stamp, and if it is necessary to express a relative judgment with respect to them, I should feel myself inclined to say that Buffon's mind had the greater aptitude for sagacious speculation, with an inferior power of acquiring and arranging a knowledge of facts of structure.

Various circumstances have concurred to favour our recollection of the merits of the great Swede, and to obscure those of the French naturalist. The well-earned fame of Linnæus is kept ever fresh in our memories by the necessarily frequent references to him in matters of nomenclature. On VOL. II. 
the other hand, not only are Buffon's claims on our esteem in no similar way brought before us, but those very speculative opinions of his, which are a merit in our eyes, gained him disfavour with our immediate predecessors, whose opinions and sentiments we more or less inherit.

No one, however, can dispute Buffon's title to our grateful respect on account of the very powerful effect his writings had in stimulating men's love of nature, an effect which I think is not sufficiently appreciated.

It is fitting that I should call attention to his (once generally recognised) claims in this respect; since my own love of natural history is probably due to the circumstance that his great work was one of the earliest with which I was familiar.

Buffon was indeed Linnæus's contemporary, for the same year (1707) saw the births of both. In 1733 he was elected a member of the Academy of Sciences, and six years later was appointed superintendent of the Jardin du Ro $i{ }^{1}$ which was the occasion of that work to which he is indebted for his fame, and to perfect which he displayed so much zeal in collecting specimens and in obtaining information respecting the various kinds of animals with which he became acquainted. His Histoire Naturelle générale et particulière began to appear in 1749, and in 1767 was published the fifteenth volume, which closed his history of mammals. Herein are contained those numerous anatomical illustrations (due, with their accompanying descriptions, to Daubenton) which have been again and again copied down to the

1 The Jardin du Roi was first instituted by Louis xIII. in 1628, and definitively established in 1635 . It cannot be affirmed that Buffon enriched the incipient museum-the Cabinet $d u$ Roi-so much as might have been expected; although the skeletons which served for Daubenton's descriptions were, at least in many instances, preserved. It is to Geoffroy St.-Hilaire that the magnificent museum of the Jardin des Plantes, which now exists, is most indebted. 
present time. Next came nine volumes on birds, then his history of minerals, and, finally, seven supplementary volumes, the last of which appeared in 1789 , the year after his death. His life was thus prolonged ten years beyond that of his illustrious contemporary, Linnæus.

Buffon can claim no merit as a classifier. With the exception of the Apes of the old and new worlds (which respectively fill the fourteenth and fifteenth volumes of his work), the beasts treated of are hardly arranged on any system, beyond that of beginning with the best known and most familiar-a system necessarily applicable to but a few forms.

But Buffon deliberately rejected the Linnæan classification -a grave error, certainly, yet one not altogether without excuse. Indeed, some of the objections he brought against that classification have considerable force. Such were his objections to the association of the hippopotamus, the shrewmouse, and the horse in one order, and of the monkey and the manis in another. ${ }^{1}$ What, indeed, could be more preposterous than the separation of the bat, Noctilio leporinus, from the other bats, and its association with the rodents, on the ground of its having (as supposed) only two incisor teeth above and two below? - an anomaly of arrangement of which you were reminded last year. It scarcely seems possible for the pedantry of classification to go further than this. Yet, perhaps, the association in one group of the walrus, the elephant, the ant-eater, the sloth, and the manatee was hardly less unphilosophical. Moreover, zoologists should not forget, in blaming Buffon for his want of appreciation of the classification of Linnæus, that one great portion of that classification-the classification of plants-has been superseded by us. Had he lived to witness the publication of Jussieu's Genera Plantarum, ${ }^{2}$ it might have given him a

${ }^{1}$ Hist. Nat. tome i. p. 39.

2 This appeared in 1789. 
truer insight into biological classification, and have led him to endeavour to improve on Linnæus's system instead of only criticising it.

But it is Buffon's speculative views which have most interest for us. Those views exercised a very widespread influence in their day, though the time was not ripe for them. Indeed, it is far from improbable that writers whose speculations have been made public at a more propitious season owe much to their comparatively forgotten predecessor.

Amongst Buffon's various speculations we might glance at his Théorie de la Terre (put forth in the very first volume of his work), and at his Epoques de la Nature, which fills the fifth volume of his supplement. We might consider his speculations concerning the formation of mountain and valley by water, and the evidence that there was present to the ear of his imagination-

'The sound of streams, which, swift or slow,

Tear down Aelian hills, and sow

The dust of continents to be.'

That he saw, in thought, the projection of the planets from the sun's mass; the primitive fluidity of the earth, and the secular refrigeration of the sun. Such considerations, however, are foreign to this Section. I will therefore select two which are of biological interest.

In the first place I may refer to Buffon's speculations concerning ANIMAL VARIATION. In this matter Isidore Geoffroy St.-Hilaire has affirmed that Buffon stands to the doctrine of animal variability in a position analogous to that in which Linnæus stands to the doctrine of the fixity of species.

Buffon, in his chapter on the animals of the Old and New World, remarks : 1 'It is not impossible that the whole ${ }^{2}$ of the

1 Op. cit., vol. ix. p. 127.

${ }^{2}$ He thought that the American Jaguars, Ocelots, etc., and even the Peccary, were positive degradations of Old World forms. He also thought that 
New World's animals are derived from the same source as those of the Old, whence they have descended. . . . Nature is in a state of perpetual flux.' In his chapter on the Degeneration of Animals ${ }^{1}$ he sums up saying: 'After comparing all the animals, and arranging them all in their own group, we shall find that the two hundred kinds described here may be reduced to a small number of original forms, whence it may be all the rest have issued.'

As to the modes and causes of the origin of new forms, he entertained four connected opinions :-

(1) He attributed much modifying efficacy to migrations ;

(2) Also to the direct action of external conditions;

(3) He believed largely in the origin of new forms by degradation; and

(4) He regarded each animal as the manifestation of an individuating force, lying, as it were, at the root of the changes manifested by it.

The view that Migration (with isolation) is a necessary antecedent to the origin of new species, is one which has been advocated by a modern naturalist, Moritz Wagner, ${ }^{2}$ who does not hesitate to affirm ${ }^{3}$ that the formation of a really new species 'will only succeed when a few individuals, having crossed the barriers of their station, are able to separate themselves for a long time from the old stock.'

In support of his view the author brings forward a multitude of interesting facts, one of the most significant of which appears to me to be the following. It concerns Beetles of Tropical America of the genus Tetracha. In Venezuela (as

the Llama, the American Apes, Agoutis, and Ant-eaters might be examples of such forms; but the Opossums, Sloths, and Tapirs he took to be original species. (See vol. xiv. pp. 272, 273.)

1 Vol. xiv. p. 358.

${ }^{2}$ In a paper read before the Royal Academy of Sciences at Munich on March 2, 1868. This has been translated by Mr. James L. Laird, and published by Edward Stanford in 1873.

${ }^{3}$ Op. cit., p. 29. 
also in the western part of Central America), he tells us, rivers flow partly through savannahs, where they have undermined the light tufaceous soil, forming deep beds with high precipitous banks. According to Professor Wagner, individual beetles from the highlands have thus been isolated, and in no longer time than has been required by the rivers to undermine the loose soil of the savannah, have given rise to a distinct species markedly different in form and colour. It is to similar causes-migration and complete isolation-that he traces the formation of distinct races of men: a formation he deems no longer possible, while the wide diffusion of mankind renders more and more difficult the evolution of new species of animals of any kind.

Instances which appear to support this view will readily suggest themselves to the naturalist-instances, that is, of forms which are both peculiar in structure and remote and isolated as to their habitat. ${ }^{1}$ Thus, for example, even in the group which structurally most resembles us, we have the Orang confined to very limited tracts in Borneo and Sumatra, and the Gorilla to a small portion of Western Africa. The Proboscis Monkey is found nowhere but in Borneo, while the singular ape named 'Roxellana' (from its wonderfully 'tiptilted' nose) is confined to the lofty and isolated mountains of Moupin in Thibet. The very peculiar black ape.(Cynopithecus) is limited to Celebes and Batchian, while the Baboon, which has the baboon character of muzzle most developed, was found at the extreme south of the African continent.

Again, if we take the group of Lemur-like animals (Lemuroidea) as having had their home and starting-point

1 Isolation, it ought to be remembered, may take place as the result not only of changes in inorganic nature (such as the formation of islands, and the excavation of river-beds), but also by the presence of enemies in intermediate tracts, by the circumstance that the food of the species is found only in certain restricted localities, and by whatever other causes determine the extinction of a species in a given place. 
in or near their present head-quarters-Madagascar,-then some of the most aberrant forms are those which must have migrated farthest. The character which is perhaps the most peculiar of any which the group presents, is the elongation of two of the ankle-bones, as we find it in the Madagascar genus Cheirogaleus. But this character is more exaggerated in migrants to Africa-the Galagos-and most so of all in the more isolated emigrant, the Tarsier, now found in Celebes and Borneo.

The sub-family of Slow-Lemurs (Nycticebince) would, on this view, seem to have migrated in opposite directions, as we find the slender Slow-Lemur (Loris) in Madras, Malabar, and Ceylon; the typical Slow-Lemur (Nycticebus) in South China, Borneo, and Java; the Potto (Perodicticus) in Sierra Leone, and the Angwantibo (Arctocebus) in Old Calabar. Of these, it is the African forms which have the index-finger most atrophied-a tendency to its atrophy existing in the whole sub-family.

It would, of course, be very easy to multiply instances of the kind; but it would be also easy to cite a number of cases which appear to conflict with the view in question. Thus familiar to us as it is, few animals are more peculiar in structure than the common Mole, which gives no present evidence of isolated origin; and the most aberrant of all Bats, the Vampire (Desmodus), is rather widely distributed in South America. Again, with regard to the Lemur group, the most absolutely exceptional is the Aye-Aye (Cheiromys), which, on the hypothesis supposed, has remained persistently at the head-quarters of the group, i.e. in Madagascar.

But even if no exception existed to the co-existence now of singularity of form with isolation and remoteness of situation, we could not safely draw any decided conclusion from such facts, because fossil remains show us that forms which have a very limited distribution were either widely 
spread in earlier times, or existed in regions very remote from those they now inhabit. Thus, in Eocene times there existed in Europe true Opossums (now confined to America), Tapirs, and a form like the African Potto before mentioned. In Miocene times we had in Europe long-armed Apes (creatures at present only found in Eastern Asia), with the now exclusively African Secretary Bird and Cape Ant-Eater (Orycteropus). In the same period the Orang-or a nearly allied form-seems to have ranged over India. What are more emphatically Old-World forms than the Camel, Horse, and Elephant, with the typical Porcupine? Yet all these existed in America in Pliocene times. Did we know the Tapir in only one of the two widely-separated stations in which it dwells to-day, we might well deem its evolution to be due to migration and isolation. But we know from palæontology that it existed in Europe from the Eocene to the Pliocene period.

Such facts as these do not, of course, disprove the doctrine that migration and isolation are necessary antecedent conditions to specific genesis; but they show how much caution must be used in drawing the conclusion that they are necessary, from the distribution of animals much less likely to be found fossil than mammals are.

But an argument in favour of the views of Buffon and of Wagner may be obtained from our own species, which exhibits some singular coincidences between peculiarity of form and isolation. Among such instances may be mentioned the Tasmanians, the Andaman islanders, and the Ainos or Aborigines of Japan. One of the most striking examples is that of the Eskimo-a people presenting many peculiarities, some of which exaggerate the characters of the highest races of mankind. Thus, the pelvis ${ }^{1}$ differs from the European pelvis in an opposite direction to that by which

${ }^{1}$ As before observed, ante, p. 176. 
the Negro pelvis differs from the European, and the same is the case with the proportions of the limbs; while the skulls of the Eskimo have the largest and narrowest nasal aperture of all races, being in this respect the very opposite to the Australians. The Eskimo have migrated eastwards, not reaching the south of Greenland till the fourteenth century, and the race characters are most marked in the most easterly tribes. These facts were brought forward by Professor Flower in his Hunterian lectures for the present year, ${ }^{1}$ when he said that the characters of this peculiar race 'must be attributed to those gradual modifications produced through causes at present little understood, by which most of the striking variations met with in the human species have been brought about-modifications more strongly expressed the more completely isolated the race has become, and the farther removed from its original centre of distribution.' I think, then, that though we have not data for conclusively answering the question as to how far migration (together with isolation) may be necessary for specific genesis, it is certain that it is of very great efficacy and importance, and that credit is justly due to Buffon for his early appreciation of its importance.

The next question to which I would advert is that concerning the direct action upon organisms of the external conditions which surround them.

Buffon's belief was ${ }^{2}$ that changes of specific form were brought about by change of temperature and climatic change generally, as well as by change of food.

The curious effects of stimulating food on colour-as of

1 The lecturer also said: 'The large size of the brain of all the hyperborean races, Lapps as well as Eskimo, seems not necessarily to be connected with intellectual development, but may have some other explanation not at present apparent.' I would suggest that in this case-as in the large brains of Cetaceans-it may be due to the need in their climate of generating much heat to sustain the necessary temperature of the body.

2 Op. cit., vol. xiv. p. 317 . 
cayenne pepper with canaries, and hempseed with parrotsare notorious. The direct action of the environment on organisms has, I think, been of late somewhat undervalued. Amongst evidences in favour of its importance, I would refer to some of Mr. Alfred Wallace's observations. ${ }^{1}$ He tells us that in the small island of Amboina, the butterflies (twelve species, of nine different genera) are larger than those of any of the more considerable islands about it, and that this is an effect plainly due to some local influence. In Celebes, a whole series of butterflies are not only of a larger size, but have the same peculiar form of wing. The Duke of York's Island seems, he tells us, to have a tendency to make birds and insects white, or at least pale, and the Philippines, to develop metallic colours, while the Moluccas and New Guinea seem to favour blackness and redness in parrots and pigeons. Species of butterflies which in India are provided with a tail to the wing, begin to lose that appendage in the islands, and retain no trace of it on the borders of the Pacific. The Aneas group of Papilios never have tails in the equatorial region of the Amazon Valley, but gradually acquire tails, in many cases, as they range towards the northern and southern tropics. Mr. Gould says that birds are more highly coloured under a clear atmosphere than in islands or on coasts-a condition which also seems to affect insects, while it is notorious that many shore plants have fleshy leaves. I need but refer to the English oysters mentioned by Costa, which, when transported to the Mediterranean, grew rapidly like the true Mediterranean oyster; and to the twenty different kinds of American trees, said by Meehan to differ in the same manner from their nearest European allies, as well as to the dogs, cats, and rabbits which have been proved to undergo modifications directly induced by climatic change:

1 See Tropical Nature, pp. 254-259. 
It appears then that much may be said in favour of that direct effect of surrounding circumstances on organisms in which Buffon believed.

Lastly, I would refer to Buffon's belief that new species have arisen by degradation. This again is an opinion which, after a period of disfavour, or at least of neglect, has been of late revived, and has acquired considerable influence. I may here refer to Anton Dohrn, who has recently advocated the very widely-spread and effective action of degradation as a cause of specific change. It will, I think, be generally admitted that such exceptional Copepod crustaceans as Tracheliastes and Lerneocera are due to degradation, and the probability seems to be very strong that the Rhizocephala, at least many cirripeds, and the cestoid worms, are also degraded organisms. Very interesting would it be to know whether existing Ascidians are also examples of degradation, as not a few zoologists now suppose; but most interesting of all is that parasite of cuttlefishes, Dicyema, the structure of which has been recently investigated by Professor Edward Van Beneden, and made the type of a new primary division of animals. Should this small worm-like organism hereafter turn out to be a degraded form, it will show what an extreme degree of retrograde metamorphosis may occasionally be brought about. I think, then, that we have considerable ground for suspecting that degradation has acted much and widely in the field of Biology, and if so, Buffon is fairly entitled to a certain amount of esteem on account of the views he entertained with regard to it in so early a day and in so undeveloped a condition of zoological science. For it must not be forgotten that migration, the influence of external conditions, and degradation, are connected points: parts of one view. Degradation is most conspicuous under violent changes of condition (such as parasitism), while migration only acts by bringing organisms under new conditions. 
These reflections lead me to urge upon such of my hearers as may have any unusual facilities for experimental investigation, a course of inquiry which seems to be very desirable.

What is needed in order to solve as far as possible the question of specific genesis, is a knowledge of the laws of variation, which must, I think, be deemed the true cause and origin of species.

We may, I think, accept as true two propositions :-

(1) Animals may change in various ways, and amongst them, by degradation.

(2) Changes in the environment with isolation, induce and favour changes in form.

I would urge, then, that inquiries should be pursued in two directions simultaneously.

(A) There might be undertaken one set of inquiries to investigate the effects on different species of the same variations of environment.

(B) Other inquiries might be undertaken with a view to ascertaining the effects of different changes of environment on one and the same species. By series of experiments contrived with these ends in view, and carried on with various selected animals and plants which reproduce with rapidity, we may possibly be able to determine what to attribute to external influences (shown by such influences having the same effects on all), and what to the peculiar nature and innate powers and tendencies of different organisms-shown by the diverging reactions of the latter under the same changes in their environment.

I next desire to direct your attention to another matter treated of by Buffon-I mean THE RESEMBLANCES AND DIFFERENCES WHICH EXIST BETWEEN THE MIND OF MAN AND THE HIGHER PSYCHICAL FACULTIES OF ANIMALS.

This question is eminently a question of our own day, and one which I feel cannot but excite interest in this Section. 
But its accurate investigation is attended with special difficulties, and amongst them are two temptations, which are apt to beset the inquirer :-

(1) The first of these arises from the widespread love for the marvellous, of whatsoever kind, and the tendency to inverted anthropomorphism.

(2) The other is the temptation to strain or ignore facts to serve a favourite theory.

As to the former of these dangers, I may perhaps be permitted to quote some remarks ${ }^{1}$ made by Mr. Chambers, approvingly cited by Professor Bain: 'There are two subjects where the love of the marvellous has especially retarded the progress of correct knowledge - the manners of foreign countries, and the instincts of the brute creation. . . . It is extremely difficult to obtain true observations' as to the latter 'from the disposition to make them subjects of marvel and astonishment. . . . It is nearly as impossible to acquire a knowledge of animals from anecdotes as it would be to obtain a knowledge of human nature from the narratives of parental fondness and friendly partiality.' This I believe to be most true, and that here the danger of mistaking inference for observation is exceptionally great. The inquirer ought not to accept as facts marvellous tales without criticism and a careful endeavour to ascertain whether the alleged facts are facts and not unconscious fiction.

As to the second danger, the lamented George Henry Lewes, whom no one can suspect of any hostility to Evolution in its most extreme form, remarks (in his posthumous work ${ }^{2}$ just published) that the researches of various eminent writers on animal psychology have been 'biassed by a secret desire to establish the identity of animal and human nature,' and certainly no one can deny that those who do assert that

1 Before cited, see ante, vol. i. p. 435.

2 Problems of Life and Mind. Third Series, 1879, p. 122. 
identity are necessarily exposed to the temptation referred to. Of course, persons who desire to disprove this identity are exposed to the opposite temptation; but it cannot be maintained that there is evidence of Buffon having been influenced by any such desire.

The obvious differences between the highest powers of man and animals have led the common-sense of mankind to consider them to be of radically distinct kinds, and the question which naturalists now profess to investigate is whether this is so or not.

But we may doubt whether many who enter upon this inquiry do not enter upon it with their minds already made up that no such radical difference can by any possibility exist. To admit it, they think, would be tantamount to admitting some non-natural origin of man, to accepting as a fact something not harmonising with our views as to nature generally, leading to we know not what results. To admit it, would be to deny the principle of continuity. There cannot, therefore, be any essential difference between man and brute, and their mental powers must be the same in kind. This, I think, is no unfair representation of the state of mind in which this question is very likely to be entered upon at the present time. Surely, however, if we profess to investigate a question, we ought in honesty to believe that there is a question to investigate, or else leave the matter to others; and if evidence should seem to show that 'intellect' cannot be analysed into sense, but is an ultimate, it ought to be accepted, at the least provisionally, as such, even at the cost of having to regard its origin as at present inexplicable. Can we explain the origin of 'motion'? But what rational man thinks of denying it on that account? Let us not reject anything, then, which may be evident, on account of certain supposed speculative consequences.

But that no such consequences as those referred to need 
follow from the admission of the radical distinctness of human reason seems evident from the views of Aristotle. He certainly was free from theological prejudices or predispositions, and yet to his clear intellect the difference between the merely sentient and the rational natures was an evident difference, and the facts which are open to our observation are the same as those which presented themselves to his.

To enter on this inquiry with any fair prospect of success, it is not only necessary to guard against such temptations as these, but it is also necessary to be provided with a certain amount of knowledge of a special kind; namely, with a clear knowledge of what our own intellectual powers are. I conceive that, great as is the danger of exaggeration and false inference as to the faculties of animals, the danger of misapprehending and underrating our own powers is far greater.

Buffon held very decided views as to the distinctness of the mind of man from the so-called minds of animals. But an ingenious and gifted writer, ${ }^{1}$ who has recently done good service in supporting Buffon's claims to greater consideration than he commonly receives, has, nevertheless, done him what I believe to be strange injustice in attributing to his great work an ironical character, and this in spite of Buffon's own protest $^{2}$ against irony in such a work as his. I cannot venture to take up your time with controversy on this subject; but, apart from Buffon's protest against 'équivoque,' it is incredible to me that he should have carried on a sustained irony through so voluminous a work-thus making its whole teaching absolutely mendacious. One remark of Buffon's, which has been strangely misinterpreted by this writer, I shall have occasion to notice directly; but I think it may suffice to clear Buffon's character from the aspersion of his

1 Mr. Samuel Butler. See his Evolution, Old and New : Hardwicke \& Bogue, 1879.

a $O p$. cit., tome i. p. 25. 
admiring assailant, to point out that in the table of contents in the final volume of his History of Mammals $^{1}$ (which table gives the pith and gist of his several treatises), he distinctly affirms the distinctions maintained in the body of his work.

The following were Buffon's views. In his Discourse on the Nature of Animals, ${ }^{2}$ he says : ' Far from denying feelings to animals, I concede to them everything except thought and reflection..... They have sensations, but no faculty of comparing them one with another; that is to say, they have not the power which produces ideas.' He is full of scorn ${ }^{3}$ for that gratuitous admiration for the moral and intellectual faculties of bees, which Sir John Lubbock's excellent observations and experiments have shown to be indeed gratuitous. Speaking of the ape, most man-like (and so man-like) as to brain, he says : ${ }^{4}$ 'Il ne pense pas: y a-t-il une preuve plus évidente que la matière seule, quoique parfaitement organisée, ne peut produire ni la pensée, ni la parole qui en est le signe, à moins qu'elle ne soit animée par un principe supérieur ?' 5 Buffon has been accused of vacillation with respect to his doctrines concerning animal variation, but no one has accused him of vacillation with respect to his views concerning reason and instinct.

I come now to the passage which I said has been so strangely misunderstood. It is that in which he expresses his conviction that 'animals have no knowledge of the past, no idea of time, and consequently no memory.' But to quote this passage without explanation, is gravely to misrepresent

1 Op. cit., tome $\mathrm{xv}$.

3 Op. cit., tome iv. p. 91.

5 Mr. Butler cites objections brought forward in a certain passage (from pp. 30 and 31, vol. xiv.), as if they were Buffon's own. But they are the objections of an imagined opponent whose views Buffon himself combats. It is worthy of note that Buffon long anticipated our contemporaries with respect to man's place in nature in so far as concerns his mere anatomy. For he did not hesitate to affirm that the Orang differs less from us structurally than it differs from some other ape. 
the illustrious French naturalist. Buffon was far from ignoring, indeed he distinctly enumerates, the various obtrusive phenomena which often lead the vulgar to attribute, without qualification, both knowledge and memory to brutes. But, in fact, he distinguishes between memory and memory. ${ }^{1}$ His words are: ' $\mathrm{Si}$ l'on a donné quelque attention à ce que je viens de dire, on aura déjà senti que je distingue deux espèces de mémoire infiniment différentes l'une de l'autre par leur cause, et qui peuvent cependant se ressembler en quelque sorte par leurs effets; la première est la trace de nos idées, et la seconde, que j'appellerais volontiers réminiscence ${ }^{2}$ plutôt que mémoire, n'est que le renouvellement de nos sensations,' and he declares ${ }^{3}$ true memory to consist in the recurrence of ideas as distinguished from revived sensuous imaginations.

This distinction is one which it is easy to perceive. That we have an automatic memory, such as animals have, is obvious; but the presence of intellectual memory (or memory proper) may be made evident by the act of searching our minds (so to speak) for something which we know we have fully remembered before, and thus intellectually remember to have known, though we cannot now bring it before our imagination.

As with memory, so with other of our mental powers, we may, I think, distinguish between a higher and a lower faculty of each; between our higher, self-conscious, reflective, mental acts - the acts of our intellectual faculty - and those of our merely sensitive power. This distinction (to which I have elsewhere ${ }^{4}$ called attention) I believe to be one of the most fundamental of all the distinctions of biology, and to be

1 Op. cit., tome iv. p. 60.

2 Here he follows, without citing, the old distinction of Aristotle between memory and reminiscence.

${ }^{3}$ Op. cit., tome iv. p. 56.

${ }^{4}$ Lessons from Nature: Murray, 1876, p. 196.

VOL. II. 
one the apprehension of which is a necessary preliminary to a successful investigation of animal psychology. It is, of course, impossible for us thoroughly to comprehend the minds of dogs or birds, because we cannot enter into the actual experience of such animals, but by understanding the distinction between our own higher and lower faculties, ${ }^{1}$ we may, I think, more or less approximate to such a comprehension.

It may, I believe, be affirmed that no animal but man has yet been shown to exhibit true concerted action, or to express by external signs distinct intellectual conceptionsprocesses of which all men are normally capable. But just as some plants simulate the sense-perceptions, voluntary motions and instincts of animals, without there being a real identity between the activities thus superficially similar, so there may well be in animals actions simulating the intellectual apprehensions, ratiocinations, and volitions of man without there being any necessary identity between the activities so superficially alike. More than this, it is certain $\grave{a}$ priori that there must be such resemblance, since our organisation is similar to that of animals, and since sensations are at least indispensable antecedents to the exercise of our intellectual activity.

I have no wish to ignore the marvellous powers of animals or the resemblance of their actions to those of man. No one can reasonably deny that many of them have feelings, emotions, and sense-perceptions similar to our own; that they exercise voluntary motion and perform actions grouped

1 Certain writers (as, for example, Professor Ewald Hering, of Prague) have used the word 'memory' to denote what should properly be called 'organic habit,' i.e. the power and tendency which living beings have to perpetuate, in the future, effects wrought on them in the past. But to call such action as that by which a tree as it grows preserves the traces of scars inflicted on it years before, 'memory,' is a gross abuse of language-a use of the word as unreasonable as would be the employment of the word 'sculptor' to denote a quarryman, or 'sculpture' to indicate the fractures made in rocks by the action of water and frost. 
in complex ways for definite ends; that they to a certain extent learn by experience, and can combine perceptions and reminiscences so as to draw practical inferences, directly apprehending objects standing in different relations one to another, so that, in a sense, they may be said to apprehend relations. They will show hesitation, ending apparently, after a conflict of desires, with what looks like choice or volition, and such animals as the dog will not only exhibit the most marvellous fidelity and affection, but will also manifest evident signs of shame, which may seem the outcome and indication of incipient moral perceptions. It is no great wonder, then, that so many persons, little given to patient and careful introspection, should fail to perceive any radical distinctions between a nature thus gifted and the intellectual nature of man.

But, unless I am greatly mistaken, the question can never be answered by our observations of animals, unless we bear in mind the distinctions between our own higher and lower faculties. ${ }^{1}$

Now I cannot here even attempt to put before you what I believe to be the true view of our own intellectual processes. Still I may, perhaps, be permitted to make one or two passing observations.

Everybody knows his own vivid feelings (or sensations), and those faint revivals of feelings, simple or complex, distinct or confused, which are imaginations and emotions; but the same cannot be said as to thought. Careful introspection will, however, I think, convince any one that a 'thought' is a thing widely different from an 'imagination'-or revival of a cluster of faint feelings. The simplest element of thought seems to me to be a 'judgment,' with an intuition of reality concerning some 'fact,' regarded as a fact real or ideal. Moreover, this judgment is not itself a modified imagination, because the imaginations which may give occa-

1 See ante, pp. 28-31. 
sion to it persist unmodified in the mind side by side with the judgment they have called up. Let us take, as examples, the judgments 'That thing is good to eat,' and 'Nothing can be and not be at the same time and in the same sense.' As to the former, we vaguely imagine 'things good to eat,' but they exist beside the judgment, not in it. They can be recalled, compared, and seen to co-exist. So with the other judgment, the mind is occupied with certain abstract ideas though the imagination has certain vague 'images' answering respectively to 'a thing being' and 'a thing not being,' and to 'At the same time' and 'in the same sense'; but the images do not constitute the judgment itself any more than human 'swimming' is made up of 'limbs and fluid,' though without such necessary elements no such swimming could take place.

This distinction is also shown by the fact that one and the same idea may be suggested to, and maintained in, the mind by the help of the most incongruous images, and very different ideas by the very same image. This we may see to be the case with such ideas as 'number,' 'motion,' 'identity,' etc.

But the distinctness of 'thought' from 'imagination' may perhaps be made clearer by the drawing out fully what we really do when we make some simple judgment, as, e.g., that ' a negro is black.' Here, ${ }^{1}$ in the first place, we directly and explicitly affirm that there is a conformity between the external thing, 'a negro,' and the external quality, 'blackness' -the negro possessing that quality. We affirm secondarily and implicitly a conformity between the two external entities and the two corresponding internal concepts. And thirdly, and lastly, we also implicitly affirm the existence of a conformity between the subjective judgment and the objective existence.

All that it seems to me evident that sentience can do, is ${ }^{1}$ An illustration which we have elsewhere used. See ante, vol. i. p. 437. 
to associate feelings and images of sensible phenomena, variously related, in complex aggregations; but not to apprehend sensations as 'facts' at all, still less as internal facts, which are the signs of external facts. It may be conceived as marking successions, likenesses and unlikenesses of phenomena, but not as recognising such phenomena as true. Animals, as I have fully admitted, apprehend things in different relations, but no one that I know of has brought any evidence that they apprehend things as related, or their relations as relations. A dog may feel shame, or possibly (though I do not think probably) a migrating bird may feel agony at the imagination of an abandoned brood; but these feelings have nothing in common with an ethical judgment, such as that of an Australian, who, having held out his leg for the punishment of spearing, judges that he is wounded more than his tribal common-law warrants.

Animals, it is notorious, act in ways in which they would not act had they reason; while, as far as I have observed or read, all they do is explicable by the association of sensations, imaginations, and emotions, such as take place in our own lower faculties. We cannot, of course, prove a negative, but we have no right to assume the existence of that for which there is no evidence, without which all the facts can be explained, and which if it did exist would make a multitude of observed facts of animal stupidity impossible. As a friend of mine, Professor Clarke, ${ }^{1}$ has put it: 'In ourselves sensations presently set the intellect to work; but to suppose that they do so in the dog is to beg the question that the dog has an intellect. A cat to bestir itself to obtain its scraps after dinner need not entertain any belief that the clattering of the plates when they are washed is usually accompanied by the presence of food for it, and that to secure its share it must make certain movements; for quite independently of such belief, and

\section{${ }^{1}$ Questions on Psychology, p. 9.}


by virtue of mere association, the simple objective conjunction of the previous sounds, movements, and consequent sensations of taste, would suffice to set up the same movements on the present occasion.' Let certain sensations and movements become associated, and then the former need not be noted: they only need to exist in order that the association should produce its effects, and simulate apprehension, deliberation, inference, and volition. ' When the circumstances of any present case differ from those of any past experience, but imperfectly resemble those of many past experiences, parts of these, and consequent actions, are irregularly suggested by the laws of resemblance, until some action is hit on which relieves pain or gives pleasure. For instance, . . . . let a dog be lost by his mistress in a field in which he has never been before. The presence of the group of sensations which we know to indicate his mistress is associated with pleasure, and its absence with pain. By past experience an association has been formed between this feeling of pain and such movements of the head as tend to recover some part of that group, its recovery being again associated with movements which, de facto, diminish the distance between the dog and his mistress. The dog, therefore, pricks up his ears, raises his head and looks round. His mistress is nowhere to be seen; but at the corner of the field there is visible a gate at the end of a lane which resembles a lane in which she has been used to walk. A phantasm (or image) of that other lane, and of his mistress walking there, presents itself to the imagination of the dog; he runs to the present lane, but on getting into it she is not there. From the lane, however, he can see a tree at the other side of which she was wont to sit; the same process is repeated, but she is not to be found. Having arrived at the tree, he thence finds his way home.' By the action of such feelings, imaginations, and associations-which we know to be verce causa-I believe all the apparently intelligent actions of animals may be explained without the need of calling in 
the help of a power, the existence of which is inconsistent with the mass, as a whole, of the phenomena they exhibit.

But if there is a radically distinct intellectual power or force in man, is such a distinction of kind so isolated a fact as many suppose? May there not exist between the forces which living beings exhibit other differences of kind?

Each living being consists of an aggregation of parts and functional activities which are evidently knit together into a unity. Each is somehow the seat or theatre of some unifying power or condition which synthesises their varied activities, and is a PRINCIPLE OF INDIVIDUATION. This seems certainly to have been the opinion of Buffon, and it is to this opinion that I referred in speaking of the fourth cause to which he attributed the changes in organic forms. And to me it seems that we must admit the existence of such a living principle. We may analyse the activities of any animal or plant, and by consideration of them separately find resemblances between them and mere physical forces. But the synthesis of such forces as we find in a living creature is certainly nowhere to be met with in the inorganic world.

To deny this would be to deny the plainest evidence of our senses. To assert that each living body is made up of minute independent organisms, each with its own 'principle of individuation,' and without subordination or co-ordination, is but to multiply difficulties, while such a doctrine conflicts with the evidence of our own perceptions, which lead each of us to regard himself as one whole-a true unity in multiplicity.

The existence in each creature of a peculiar, co-ordinating, polar force seems to be specially pointed to by the phenomena of serial and bilateral symmetry, by the symmetrical character of certain diseases, by the phenomena of monstrous growths, and by the symmetrical beauty of such organisms -as the Radiolarian Rhizopods. ${ }^{1}$

1 See below, pp. 265-267. 
It also seems to me to be made evident, by the various activities of each animal, which are, as a fact, grouped in one in mutual interaction-an organism having been described by Kant as a creature, the various parts of which are reciprocally ends and means.

I think now I hear the exclamation-This is 'Vitalism!' while some of my hearers may deem these matters too speculative for our Section.

But consciously or unconsciously, general conceptions of the kind exist in the minds of all biologists, and influence them in various ways, and their consideration, therefore, can hardly be out of place here; while as to 'Vitalism,' I am convinced I shall not be wasting your time in endeavouring to remove a widespread misconception.

The 'Vitalism' which is so reasonably objected to is that which supposes the existence in each living creature of some separate entity inhabiting the body-an extra-organic force within the living creature, and acting by and through it, but numerically distinct from it. But the view which I venture to put before you as that which is to my judgment a reasonable one, is that of a peculiar form of force which is intraorganic, so that it and the visible living body are one thing, as the impress on stamped wax and the wax itself are one, though we can ideally distinguish between the two. It is, in fact, a mode of regarding living creatures with prime reference to their activities rather than to their material composition, and every creature can of course be regarded either statically or dynamically. It is to regard any given animal or plant, not as a piece of complex matter played upon by physical forces, which are transformed by what they traverse, but rather as a peculiar immanent principle ${ }^{1}$ or form of force

${ }^{1}$ This term has been used to denote that activity which, together with material substance, constitutes a living creature, because it calls up a less sensuous, and therefore less misleading, phantasm than any other. The old term $\psi v \chi \eta^{\prime}$, or soul, has become associated with the idea of a substance numeri- 
(whensoever and howsoever arising), which for a time manifests itself by the activities of a certain mass of complex material, with which it is so entirely one, ${ }^{1}$ that it may be said to constitute and be such animal or plant much rather than the lump of natter which we can see and handle can be said to constitute such animal or plant. On this view a so-called 'dead bird' is no bird at all, save by abuse of language, nor is a 'corpse' really a 'dead man'- such terms being as selfcontradictory as would be the expression 'a dead living creature.'

Thus the real essence, the substantial constituent, of every living thing is something which escapes our senses, though its existence and nature reveal themselves to the intellect.

For of course our senses can detect nothing in an animal or plant beyond the qualities of its material component parts. But neither is the function of an organ to be detected save in and by the actions of such organ, and yet we do not deny it its function or consider that function to be a mere blending and mixture of the properties of the tissues which compose it. Similarly it would seem to be unreasonable to deny the existence of a living principle of individuation because we can neither see nor feel it, but only infer it. This power or polar force, which is immanent in each living body, or rather which is that body living, is of course unimaginable by us, since we cannot by imagination

cally distinct from the living body, and capable of surviving the destruction of the latter. But as structure and function ever vary together (as do the convexities and concavities of a curved line), so 'the principle of individuation' or soul of an animal or plant and its material organisation must necessarily arise, vary, and be destroyed simultaneously, unless some special character, as in the case of man, may lead us to consider it exceptional in nature. Even in man, however, there seems no adequate reason for believing in the existence of any principle of individuation, save that which exerts its energy in all his functions, the humblest as well as the most exalted.

${ }^{1}$ See ante, vol. i. p. 430. 
transcend experience, and since we have no experience of this force, save as a body living and acting in definite ways.

It may be objected that its existence cannot be verified. But what is verification? We often hear of 'verification by sensation,' and yet even in such verification the ultimate appeal is not really to the senses, but to the intellect, which may doubt, and which criticises and judges the actions and suggestions of the senses and imagination. Though no knowledge is possible for us which is not genetically traceable to sensation, yet the ground of all our developed knowledge is not sensational, but intellectual; and its final justification depends, and must depend, not on 'feelings,' but on 'thoughts.' I must apologise to such an audience as that I have the honour of addressing for expressing truths which, to some of my hearers, may appear obvious. I would gladly suppress them as superfluous did not my own experience convince me that they are not superfluous. To proceed: 'Certainty' does not exist at all in feelings any more than doubt. Both belong to thought only. 'Feelings' are but the materials of certainty, and though we can be perfectly certain about our feelings, that certainty belongs to thought and to thought only. 'Thought,' therefore, is our absolute criterion. It is by self-conscious thought only that we know we have any feelings at all. Without thought, indeed, we might feel, but we could not know that we felt or know ourselves as feeling. If then we have rational grounds for the acceptance of such a purely intellectual conception as that of an immanent principle as the essence of each living creature, the poverty of our powers of imagination should be no bar to its acceptance. We are continually employing terms and conceptions-such, e.g., as ' being,' 'substance,' 'cause,' etc.-which are intelligible to the intellect (since they can be discussed), though they transcend the powers of the imagination to picture. 


\section{Address to the British Association}

It seems to me that the spirit which would deny such realities is the same spirit which would deny our real knowledge of an external world at all, and represent any material object as 'a state of consciousness,' and at the very same time represent 'a state of consciousness' as the accompaniment of a peculiar state of a material object-the body. ${ }^{1}$ This mode of representation may be shortly, but not unjustly, described as a process of intellectual 'thimble-rigging,' by which the unwary spectator is apt to be cheated out of his most valuable mental possession - his rational certainty.

The same spirit asserts that our psychical powers never themselves enter into the circuit of physical causation, and yet few things would seem more certain to a plain man than that (supposing him to have received a message saying his house is on fire) it is his knowledge of what has been communicated which sets him in motion. To deny this is to deny the evident teaching of our consciousness. It is to deny what is necessarily the more certain in favour of what is less so. If I do not know this I know nothing, and discussion is useless. As a distinguished writer has said: 'That we are conscious, and that our actions are determined by sensations, emotions, and ideas, are facts which may or may not be explained by reference to material conditions, but which no material explanation can render more certain.' The advocate of 'Natural Selection' may also be asked, How did knowledge ever come to be, if it is in no way useful, if it

1 Those who deny that we have a real power of perceiving objects refute themselves when they speak of 'purely physical changes,' or of anything 'physical' of which feelings are but the 'accompaniment' or 'subjects.' For according to them 'matter' is but a term for certain 'states of consciousness,' while they represent each state of consciousness as a function of matter. According to this, let $a$ represent a 'state of consciousness, and $b$ a physical state.' Then a sensation and its physical accompaniment may be represented by the symbol $a+b$. But a physical state is itself but a state of consciousness with its objective correlate, and is, therefore, $a+b$. We thus get an equation infinitely more erroneous than $b=a+b$, because the $b$ of the $a+b$ is itself ever again and again $a+b$. 
is utterly without action, and is but a superfluous accompaniment of physical changes which would go on as well without it?

As we may be confident that thought not only is but also acts, as well as that there are things which are not psychical, but which are physical; so I would urge that the conception of living things, which I venture to put before you, is one which may be rationally entertained.

Assuming for the moment and for argument's sake that it may be accepted, what light does our knowledge of ourselves throw upon the intimate life-processes of lower organisms? We know that with us a multitude of actions, which are at first performed with consciousness, come to be performed unconsciously; we know that we experience sensations $^{1}$ without perceiving them; we know also that countless organic activities take place in us under the influence and control of the nervous system, which either never rise into consciousness at all, or only do so under abnormal conditions. Yet we cannot but think that those activities are of the same generic nature, whether we feel, perceive, or attend to them or not. The principle of individuation in ourselves, then, evidently acts with intelligence in some actions, with sentience in many actions, but constantly in an unperceived and unfelt manner. Yet we have seen it undeniably intervene in the chain of physical causation.

An animal is an organism, all the actions of which are necessarily determined by the adjustments of its various organs, and by its environment. But even its sensations cannot be regarded as mere accompaniments of its activities,

1 As when having gazed vacantly through a window we revert to the pages of a manuscript we may be writing, and see there the spectra of the window bars we had before unconsciously seen. Here the effect on the organism must have been similar to what it would have been had we attended to it-i.e. it was an unfelt sensation. 
but as guides and directing agencies intervening in the circle of its actions, and as facts in a chain of physical causation. The sight of a stick may change the course of actions which a dog would otherwise have pursued-that is, the feeling of the moment, together with the faint recurrence of various past feelings and emotions therewith associated, which the sight of the stick calls up, may cause such change. Besides its feelings, the general and the organic movements of the dog are, like our own, governed by a multitude of organic influences which are not felt, but which operate through the nervous system, and so must be taken as parallel with those which are felt, i.e. as unfelt, nervous psychoses. The animal, then, like each of us, is a creature of activities partly physical, partly psychical, the latter--both the felt and the unfelt-being directing and controlling.

As we descend to the lowest animals, the evidence as to sentience fades. Yet from the resemblances of the lowest animals and plants, and from the similarity of the vegetative functions in all living creatures, we may, I think, analogically conclude that activities also take place in plants which are parallel with, and analogous to, the unfelt psychoses of animals. As Asa Gray has said with respect to their movements: 'Although these are incited by physical agents (just as analogous kinds of movements are in animals), and cannot be the result of anything like volition, yet nearly all of them are inexplicable on mechanical principles. Some of them at least are spontaneous motions of the plant or organism itself, due to some inherent power which is merely put in action by light, attraction, or other external influences.'

I have already adverted to insectivorous plants, such as Dioncea. In such plants we have susceptibilities strangely like those of animals. An impression is made, and appropriate resulting actions ensue. Moreover, these actions do not take place without the occurrence of electrical changes similar to 
those which occur in muscular contraction. Hardly less noteworthy are the curious methods by which the roots of some plants seek moisture as if by instinct, or those by which the tendrils of certain climbers seek and find appropriate support, and having found it, cling to it by a pseudo-voluntary clasping, or, finally, those by which the little 'Mother-of-athousand' explores surfaces for appropriate hollows in which to deposit her progeny.

Nevertheless, nothing in the shape of vegetable nervous or muscular tissue has been detected, and as structure and function necessarily vary together, it is impossible to attribute sensations, sense-perceptions, instincts, or voluntary motions to plants, though the principle of individuation in each acts as in the unfelt psychoses of animals and harmonises its various life processes.

The conception, then, which commended itself to the clear and certainly unbiased Greek intellect of more than two thousand years ago, that there are three orders of internal organic forces, or principles of individuation, namely, the rational, the animal, and the vegetal, ${ }^{1}$ appears to me to be justified by the light of the science of our own day.

I come now to the bearing of these remarks on the science of Biology generally.

Animals and plants may, as I have before said, be regarded either statically, by anatomy, or dynamically, by physiology.

Physiology, as usually understood, regards the properties

1 Difficult as it confessedly is to draw the dividing line between animals and plants, such difficulty is not inconsistent with the existence of a really profound difference between the two groups. That there should be a radical distinction of nature between two organisms, which distinction our senses, nevertheless, more or less fail to distinguish, is a fact which on any view must be admitted, since animals of very different natures may be indistinguishable by us in the germ, and in the earlier stages of their development. The truth of this is practically supported by the late Mr. Lewes. See the passage quoted ante, vol. i. p. 433 . 
of the ultimate morphological components of organisms, the powers of the various aggregations of such components, i.e. of the various 'tissues' and the functions of the different special aggregations and arrangements of tissues which constitute 'organs.'

But as each living creature is a highly complex unityboth a unity of body and also a unity of force, or a synthesis of activities-it seems to me that we require a distinct kind of physiology to be devoted to the investigation of such syntheses of activities as exist in each kind of living creature. I mean to say that just as we have a physiology devoted to the several activities of the several organs, which activities are the functions of those organs, so we need a physiology specially directed to the physiology of the living body considered as one whole, that is, to the power which is the function, so to speak, of that whole, and of which the whole body, in its totality, is the organ.

In a word, we need a physiology of the individual. This science, however, needs a distinct appellation. I think an adequate one is not far to seek.

Such a line of inquiry may be followed up, whatever view be accepted as to the nature of those forces or activities which living creatures exhibit. But if we recognise, as I myself think our reason calls on us to recognise, the existence in each living being of such a 'principle of individuation' as I have advocated the recognition of, then an inquiry into the total activity of any living being considered as one whole is tantamount to an inquiry into the nature of its principle of individuation. Such an inquiry becomes 'Psychology' in the widest and in the original signification of that term-it is the Psychology of Aristotle.

Mr. Herbert Spencer has already made a great step towards reverting to this original use of the term, for he has made his 'Psychology' conterminous with the animal king- 
dom, having made it a history of the psychoses of animals. But the activities of plants must not be ignored. A science which should include the impressionability and reactions of a Rhizopod, and exclude the far more striking impressionability and reactions of Venus's Fly-trap, and of other insectivorous plants, the recognised number of which is greatly on the increase, must be a very partial and incomplete science. If Psychology is to be extended (as I think $\mathrm{Mr}$ Spencer is most rational in extending it) to the whole animal kingdom, it must be made to include the vegetable kingdom also. Psychology, thus understood, will be conterminous with the whole of Biology, and will embrace one aspect of organic dynamics, while Physiology will embrace the other. ${ }^{1}$

Physiology will be devoted (as it is now) to the study of the activities of tissues, of organs and of functions, per se, such, e.g., as the function of nutrition, as exhibited in all organism from the lowest plants to man, the functions of respiration, reproduction, irritability, sensation, locomotion, etc., similarly considered, as manifested in the whole series of organic forms in which such powers may show themselves.

Psychologr will be devoted (according to its original conception) to the study of the activities of each living creature considered as one whole-to the form, modes, and conditions of nutrition and reproduction as they may coexist in any one plant; to these as they may coexist with sensibility and motility in any kind of animal, and finally to the coexistence of all these with rationality as in man, and to the interactions and conditions of action of all these as existing in him, and here the science which corresponds to the most narrow and restricted sense of the word, psychology, i.e. the subjective psychology of introspection, will find its place.

Psychology, in the widest sense of the term, in its oldest, and in what I believe will be its ultimate meaning, must

${ }^{1}$ As before pointed out, see ante, vol. i. p. 429. 
necessarily be, as to its details, a science of the future. For just as Physiology requires as a necessary antecedent condition a knowledge of anatomy-since we must know that organs exist before we investigate what they $d o$ - so Psychology requires as a necessary antecedent condition an already advanced physiology. It requires it because we must be acquainted with the various functions before we can study their synthesis and interactions.

When, however, this study has advanced, one most important result of that advance will be a knowledge, more or less complete, of the innate powers of organisms, and therefore of their laws of variation. By the acquisition of such knowledge we shall be placed in a position whence we may advance, with some prospect of success, to investigate the problem of the 'Origin of Species'-the biological problem of our century.

This reflection leads me back once more to my startingpoint, the merits of the great French naturalist of the last century, whose views as to variation, and as to animal psychosis, have enabled me to bring before you the questions on which I have presumed to enter. Buffon's claims on our esteem have, I think, been too much forgotten, and I rejoice in this opportunity of paying my debt of gratitude to him by recalling them to recollection. As to the questions which his words have suggested to me and upon which I have thus most imperfectly touched, the considerations I have ventured to offer may or may not commend themselves to your approval; but, at least, they are the result of not a few years of study and reflection, and I am persuaded they have consequences directly or indirectly affecting the whole field of biological inquiry, which belief has alone induced me to make so large a call upon your patience and your indulgent kindness. 
FORCE, ENERGY, AND WILL.

$\mathrm{O}^{\mathrm{NE}}$ benefit due to the advance of physical science is, as Professor Clerk Maxwell has remarked, the introduction into common speech of words and phrases consistent with true ideas about nature instead of others implying false ideas. But though our scientific progress has produced this amongst so many other beneficent effects, yet, as its advancing stream has left here and there a stagnant pool, so we may not unreasonably expect every now and then to meet even with a temporary verbal backwater. Thus electrical discovery by the term 'electric fluid' has left in the popular mind the illusion that electricity is a fluid substance which flows from one body to another. But a really grave misconception (in some respects a retrograde error) appears to me to be coming daily more diffused with regard to the conceptions 'energy' and 'force.'

The term 'force' has, of course, definite and exact meanings ${ }^{1}$ (not always quite consistent, however,) assigned to it in

1 Thus Professor Tait, in his Lectures on Some Recent Adrances in Physiral Science, defines (at page 16) 'force' as 'any cause which alters or tends to alter a body's natural state of rest or of uniform motion in a straight line. At page 354 he says : 'Force is the rate of change of momentum,' and adds that the term 'is obviously to be applied to any pull, push, pressure, tension, attraction or repulsion, etc., whether applied by a stick or a string, a chain or a girder, or by means of an invisible medium such as that whose existence is made certain by the phenomena of light and radiant heat.' At page 358 he adds: 'Force is the rate at which an agent does work per unit of length.' In Nature, July 5, 1877, he tells us : 'In all probability there is no such thing as force.' Force is often taken to denote 'the unknown cause of energy, 'energy being the power possessed by a body of overcoming a resistance. Force is also defined as 'mass animated by velocity, or directed pressure.' 
physics; but it is the more general, not the exact use of the term to which reference is here made. 'Force' becomes known to us partly through the sense of effort and resistance overcome which attends our muscular activity, and partly through the exercise of will, as perceived in exerting our voluntary mental activity-force of mind being a term of familiar use as well as force of arm. We have, therefore, force in our own being as the active exercise of mental and bodily powers which are possessed by our complex organisms. The sensations of effort and resistance we experience, are the occasions through and by which our intellect coines to perceive that surrounding bodies have powers corresponding to our ()wn. We do not, however, as some pretend, attribute to surrounding bodies activities such as our own, but only activities having a certain analogy with ours. If we try to pull a man up from the ground against his will, and fail from his being more muscular than we are, and if we try to pull up a stone from the ground and fail from its being too heavy to lift, we do not attribute muscular activity to the stone, or to the earth which by gravity retains it; but we perceive a certain relation of analogy between the pulling activity of the man and the pulling activity of the earth, and this though our own sensations constitute the one material by means of which our intellect has the power of apprehending those two very different perceptions. As it is with gravity, so with the other influences (luminous, calorific, electrical, etc.) which surrounding bodies bring to bear on us; we naturally recognise them as the actively exercised powers and properties of such bodies. The sleeper who wakes to find that the earth's rotation has carried him from beneath a tree's friendly shade into the direct influence of a scorching sun, believes that the heat he experiences is due to the activity of that great body acting upon his own organisation, and also believes that activity to be something radically and essentially different 
both from the activity which blinds him when he attempts to gaze at the sun itself, and from the motion which has exposed him to its rays. Is he right in so believing? If he is, then much of our modern scientific teaching tends to render popular, phrases which imply false ideas about nature, and thus to occasion such an intellectual backwater as has been referred to. The false physical conception also carries with it consequences of far greater moment.

The scientific teaching which I believe implies false ideas about nature is that which concerns the 'conservation of energy,' ${ }^{1}$ or, as it was earlier named, the 'persistence and transformation of force.' Few conceptions have of late obtained a wider currency amongst that part of the public which is interested both in physical science and philosophical speculation than have three represented by the expressions ' the unity, the persistence, and the transformation of force.'

As to the idea of the metamorphosis of 'force,' Meyer, Joule, Grove, and Helmholtz are perhaps, as Mr. Herbert Spencer says, 'more than any others to be credited with' its 'clear enunciation'; but certainly its wide diffusion has been largely aided by one who adds to his many claims on our esteem, as a man of science, the gift of a most persuasive eloquence. Indeed, Professor Tyndall's clear expositions of scientific facts, supplemented by the charm of his brilliant rhetoric, have familiarised so many minds amongst us with the conception of the transformation of force, that now a reverent acceptance of this belief seems to have become, in the opinion of many, the articulus stantis vel cadentis scientice.

But the conception of a persistent 'force' which undergoes Protean transformations has found large acceptance in philosophy no less than in science. The many who take

1 Professor Tait, in the work before referred to, speaks (p. 362) of ' the fast rising temple of science, known as the law of the conservation of energy.' 
Mr. Herbert Spencer as their speculative guide follow him in seeking to express all existences of which we have or can have any knowledge in terms of 'force'-its persistence and metamorphosis-as their only possible ultimate explanation. IIr. Spencer himself has a chapter ${ }^{1}$ on the transformation of 'force,' wherein he speaks of 'the transformation of heat into electricity,' and of this latter, again, 'into other modes of force'; he refers to Mr. Grove as having shown 'that each force is transformable, directly or indirectly, into the others,' and he himself brings even intellect and will within the sphere of such transformations. Indeed he not only teaches that force is a substance, but that it is the substance of substances. He makes the persistence of force as 'an unconditioned reality' 2 the most fundamental of all truths. 'Deeper,' he tells us, ${ }^{3}$ 'than demonstration, deeper even than definite cognition, deep as the very nature of mind, is the postulate at which we have arrived. . . The sole truth which transcends experience by underlying it is the persistence of force.' Here, then, we have a fundamentally different conception of 'force' from that which was formerly universal-the conception, in fact, of an actual multiform substance instead of the conception of a property attached to substance, i.e. the activity of a substance.

This change of conception has been brought about by the brilliant discoveries of the quantitative equivalence which exists between the different successive activities of the same or of different bodies, e.g. that quantitative equivalence between heat and motion which has led Professor Tyndall to speak of heat as 'a mode of motion.' The works of the authors before referred to are replete with wonderful exanples of this quantitative equivalence between many of the activities which bodies exhibit.

1 FirstPrinciples, 3rd edition, chapter viii.

L. c., p. 189.

${ }^{3}$ L. c., p. 192. 
We shall naturally at first be disposed to think that a conception based upon such discoveries, and which has been propagated energetically by thinkers so distinguished, must be a valid one, and that the new phraseology must therefore be a real improvement. Now I should be the last to underrate either the value of the physical discoveries of equivalence between activities or the merit of the illustrious discoverers. Deference is most justly due to the expressed opinions of such men, and we may well hesitate before venturing to regard as mistakes what they appear to deem so important and so true. We have, however, but to consult the history of a few years back to find sufficient evidence that the most distinguished leaders of thought may fall into the most elaborate speculative errors. Hegel and Schelling, in their day, were men at least as eminent and as esteemed as any of our living philosophers. Yet who now believes that any profound truth lies hid in the judgment that 'being and notbeing are identical,' enunciated by the former, or considers that the biological speculations of the latter have any real scientific value? On the other hand, there are not a few who feel no trifling grudge against these writers for having led them through the fame of their writings to expend much time in acquiring a knowledge of systems which when acquired proved empty and worthless. I should be very sorry to be thought wanting in respect for the labours and fruitful speculations of the veteran Professor Schwann, who will ever deserve the gratitude no less than the admiration of biologists; but fully recognising his merits, we may yet ask, Who now accepts his cell theory as put forward by him?

Fortified with such reflections, we need not shrink from respectfully questioning the conclusions of the most distinguished physicists or the most widely accepted philosophers of to-day, even if it were not the rule both in science and 
philosophy to be ever demanding demonstration, and never resting on authority. We may then without scruple express not only our scepticism, but our positive disbelief in the new creed-' I believe in One Force'-and we need not shrink from entering our protest against the danger of superstition contained in this credo. The protest seems to me needed, for I fail to see why a belief in a supposed, but really nonexistent, agent, invisibly entering into and as invisibly quitting the visible objects around us, should be deemed other than superstitious.

But what, then, is this awful reality of which all known or knowable existences are but modes? This force, this now so widely reverenced entity, the Alpha and Omega of the Spencerian school, this Being of Beings, which seems the great Pan not only alive once more, but actually seizing on the vacant throne of Zeus, is, in my judgment, a mere figment of the intellect. For 'force' is but an abstraction, a common term denoting the diverse activities of all known and unknown existing substances, and it has therefore no existence, as force, other than as an idea in some mind. The attempt, then, to explain all phenomena by the persistence and transformation of force, is an attempt to explain everything by an abstraction.

This new way of speaking has, not unnaturally, come into fashion as a consequence of the recognition of that quantitative equivalence between successive activities which has been of late years so happily discovered, and which can be most conveniently expressed by it. But though it is thus convenient to express such changes (especially experimental changes accurately measured) in terms of ' a persistent force,' yet all the physical phenomena capable of expression in such terms seem to me to be also capable of expression in terms of the hypothesis that bodies of different kinds really exist objectively, and have, really and objectively, active powers 
of different kinds. The conception of the same or different bodies being successively affected, and acting successively in different manners, with a quantitative equivalence between the modes of their affection and activity, seems a sufficient conception to apply to the mechanism and action of a moving locomotive steam-engine, etc.-one as consonant with facts as is the conception of a force which is transformed from heat into motion.

On the other hand, to speak of force persisting and being transformed, favours the conception of force as some objectively existing thing which really passes out of one body into another, and has a positive substantial existence. Thus it is sometimes said that a coal-bed contains the heat and light of the sun of bygone ages shut up within it, like enchanter knights, and once more to be set free upon that coal's combustion. But does it really contain them? Surely neither that light nor that heat is in the coal, nor are they in the oxygen with which that coal may one day combine; they are activities resulting from the rapid combustion of those bodies.

It may perhaps be replied that there has in fact been no intention of really inculcating the substantial existence of force, and that the language used has been employed simply. as a convenient way of speaking. Now, I most willingly concede the reasonableness of making use of the conception of such an entity as 'force' as a working hypothesis, provided care be taken that its real nature be not misunderstood; but if by that term not a real existence, but an ideal abstraction be, in fact, what is meant, then it would surely be better not to speak of its 'persistence,' and a fortiori of its 'transformation,' since nothing can be 'transformed which does not really exist.

It will perhaps be replied that if we ought not to speak without qualification of force, we ought not so to speak even 
of particular forces-heat, light, and electricity, etc.-which, as such, are also abstractions; that we ought, in fact, to atvoid the common phrases employed in everyday life. To this it may be rejoined, in the first place, that the active powers of bodies do really exist, and that therefore it is most reasonable to apply to similar powers a common name; while for the real, though not the substantial, existence of calorific, luminous, and electric activities we have the plainest evidence. Nor need we even object to the term -force' as a common name for all active powers whatever, provided its substantial existence, beside the existence of the various active bodies, be not asserted or implied. But secondly, I reply that though it is well to employ the common terms, heat, light, electricity, etc. (meaning by such ternns the objective activities to which our sensibilities become related), it is also well from time to time to make clear that such entities are abstractions (though less abstract in degree than 'force'), and have no existence other than ideal apart from warm, luminous, or electrified bodies.

The utility of the latter course seems to me to be made plain by such considerations as the following:-It is often said that bodies may, by impact, communicate motion, as when one suspended ball, falling against others, ceases itself to move, while another begins to be in motion. But we have here no real evidence of any 'communication' or 'transference' of 'motion,' but only of successive and correlative motions. The language used with respect to this phenomenon (the 'transference' of 'motion') shows the existence of a tendency to regard the abstract quality 'motion as a substantial entity, actually passing from one body to another. But if force were a substantial entity actually passing from one body to another, it would have to traverse space in so passing, and whan can that be which is to make it so pass, and govern it in transitu? Either for that we require 
another force, or else force moves itself, and thus we have the conception of a new substance with active powers gratuitously introduced in order to explain the activities of the two bodies (the balls) - the moving and the moved.

If by 'force' and its 'persistence' be meant 'cause,' and if I am challenged to admit the 'persistence of cause' as a necessary article of my philosophical creed, I answer by as readily denying the real existence of the abstraction 'cause' as the existence of the abstraction 'force.' But because the existence of an abstraction be denied, it by no means follows that the existence of an objectively real, persistent cause should be also denied. Indeed, just as reason seems to tell me that bodies with active powers exist -concrete existences, with very real and very special powers - so reason seems to tell me that one concrete cause exists, the most real of realities, the most powerful of powers-God.

But the title of this paper refers not to 'force' only, but also to 'energy,' and it does so because of the change of language which has recently taken place. Physicists have ceased, or are ceasing, to speak of the persistence and transformation of force: we hear now only of the persistence and transformation of energy. In what sense, however, is the word 'energy' really used? In every known activity of any body, e.g., in heat, we have manifested (1) the sensible perception by which it becomes known to our senses-in the case supposed the sensation of heat; and (2) the intellectual perception of an objective power or activity of a definite kind in the body which acts upon our organism. Now, if the word 'energy' is used in the sense of 'bodily activity,' there is nothing to be said against it save that it is a somewhat obscure and ambiguous expression. Moreover, though the quantitative equivalence between successive activities is indeed a great discovery reflecting high honour on the discoverers, yet the transformation of energy in the 
sense of the transformation of activities, is what everybody knew of since man first made fire by rubbing sticks together. The word 'energy,' however, is, at the least, too often used in such a way as to be in fact our old friend 'force' in a new costume. Thus Professor Tait ${ }^{1}$ gives as examples of energy, the energy of any current of water capable of driving an undershot wheel; of winds which also are used for driving machinery; the energy of water-waves or of sound-waves; the radiant energy which comes to us from the sun,' etc. By these expressions Professor Tait cannot evidently mean merely the activity of running water, but its 'force' as that word is commonly understood, and so of his other forms of energy. To the expression the 'transformation of energy' in this sense all the objections apply which have already been made to the expression 'transformation of force.' I contend then that care should be taken not so to speak of force and energy as to lead to the belief in their substantial existence, ${ }^{2}$ as force and energy, and I object to the phrases 'unity

1 Lectures on Some Recent Advances in Physical Science, p. 359.

2 Professor Tait (l. c. p. 55) tells us that Mayer 'actually says it (i.e. motion) must cease to be motion in order to become heat,' thus implying that in his (Professor Tait's) opinion, motion does not cease to be motion in becoming heat. Nevertheless he is very severe (by implication) upon Professor Tyndall for simply saying that heat is a mode of motion. Professor Tait (p. 362) observes: 'The conception of kinetic energy is a very simple one, at least when visible motion alone is involved. And from motion of visible masses to those motions of the particles of bodies whose energy we call heat, is by no means a very difficult mental transition. Mark, however, that heat is not the mere motions, but the energy of these motions-a very different thing, for heat and kinetic energy in general are no more modes of motion than potential energy of every kind (including that of unfired gunpowder) is a mode of rest!' But surely this is a piece of hypercriticism, and one moreover very obscurely and even incorrectly expressed. Much as I deprecate as false and misleading the phrase 'heat a mode of motion,' yet Professor Tait has no right to object to it as a popular way of speaking, which is how Professor Tyndall used it. Professor Tait seems to object to the use of the term 'motion' as denoting 'motion in the abstract'; but if so, then he should not have objected (as above quoted) that 'heat is not the mere motions, but the energy of these motions'; he should have objected 'heat is not the mere motions in the abstract, but the motions of the molecules.' 
of force' or 'transformation of energy' as irrational and profoundly misleading. I do not, of course, deny their existence as abstractions from really existing sensible concretes (which concretes exert real activities), as the notions ' society' and 'the state' are abstracts from really existing men. But just as a misuse of these latter terms (especially the state) seems to me often to tend to grave political evils, and to the sacrifice of concrete individuals (real men and women) for the sake of a mere abstraction, so a misuse of the abstract terms force and energy seems to me to tend to serious intellectual evils.

These evils have just been made remarkably plain by the Presidential address recently delivered by Professor Tyndall at Birmingham, republished under the title Science and Man. ${ }^{1}$ Therein the author teaches the doctrine of the persistence and transformation of energy, and makes such teaching the occasion and basis for an eloquent attack on the freedom of the will. Thus to the denial of the essential distinctness of the different kinds of bodily activity, which we know as the different physical forces, follows naturally the denial of the essential distinctness of those activities termed vital, and to the denial of these latter succeeds the denial of the essential distinctness of the activities we know as mental. The whole system of denial, however, seems to repose upon a hasty, almost gratuitous, assumption that from the quantitative equivalence found to exist between forces their essential unity necessarily follows.

It may be worth while to consider a little the last culminating expression of a system reposing upon such a basis; noticing by the way some defects of apprehension and of reasoning which, I venture to think, should make the unprejudiced reader pause before attaching weight to the Professor's opinions on matters foreign to that physical science in which we all admiringly recognise his just claims

${ }^{1}$ See Fortnightly Review for November 1877, p. 593. 
to respectful deference. The Professor brings forward from Lange ${ }^{1}$ (as an example) the case of a merchant who, on reading a telegram, is aroused to immediate energetic and complex action, and the author pronounces that the whole of the activities thus aroused are phenomena 'produced by, or associated with, the molecular processes set up by waves of light in a previously prepared brain.' His treatment of the subject makes it evident that the Professor thinks a Christian theologian must necessarily object to the sentence just (quoted, and he seems to consider that its acceptance would, in some way, tell against the doctrine of the substantiality and immortality of the soul of man. That the merchant's knowledge was not a mere accompaniment of his physical state, but also a cause of subsequent actions, cannot of course be known to a spectator save as an inference from what such spectator knows concerning his own nature; but inasmuch as all reasonable men (who have no eccentric thesis to maintain) know that knowledge is in themselves a cause of action, ${ }^{2}$ they very properly infer that the same is the case in their fellow-men also. Similarly it suffices to have realised in one's-self the essential difference between a faint or 'revived sensation' and a 'thought,' to recognise the reasonableness of explaining the merchant's activity by the spontaneity of his mind or soul.

It is interesting to observe all that Professor Tyndall has to say against the hypothesis of a human soul acting in Lange's merchant. He tells us :-

'Adequate reflection shows that instead of introducing light into our minds, it increases our darkness. You do not in this case explain the unknown in terms of the known, which, as stated above, is the method of science, but you explain the unknown in terms of the more unknown. Try to mentally visualise this soul as an entity distinct from the body, and the difficulty immediately appears.'

1 P. 605.

${ }^{2}$ See ante, p. 219. 
Now of course it is impossible to 'mentally visualise' that which the eye has never seen-but is the invisible necessarily incredible? Professor Tyndall's own discoveries make it impossible for him to affirm such a proposition. It is concederl on all hands that we cannot by imagination transcend experience, and we have experience of 'souls' only in the energies of 'living bodies'; but is that any reason for disbelieving in them? This question brings us to that of the ultimate ground of all knowledge, and to the Professor's assertion, that the hypothesis of a soul is an explanation of 'the unknown in terms of the more unknown.' But far from this, the explanation is in terms of the most known of all, for we know nothing external so certainly as we know our own personal existence. Though no knowledge is possible to us except as following upon sensation, yet the ground of all developed knowledge is not sensational but intellectual-it reposes ultimately not on 'feeling' but on thoughts. ${ }^{1}$ Even in verification by sensation it is the intellect which doubts, criticises, and judges the actions and suggestions of the senses and imagination; and if we have (as I am confident we have) rational grounds for adopting such a purely intellectual conception as that of the human soul, the poverty of our powers of imagination should be no bar to its acceptance. We are continually employing conceptions of the kind-such, e.g., as number, being, substance, cause, etc.-conceptions perfectly intelligible though transcending the powers of the imagination. The utterly unimaginable may be the most supreme of certainties, and what in its nature is necessarily undemonstrable to sense, need be none the less clear on that account to the eye of the intellect. To that same eye is alone visible our own continued personal existence and identity, which is vouched for by higher evidence than that of sensation.

Such is Professor Tyndall's argument against the exist-

${ }^{1}$ See ante, p. 218. 
ence of the human soul; his arguments against free-will rather resemble what we might expect to hear put forward at any meeting of secularist artisans than the arguments of one of his scientific eminence. He asks, ${ }^{1}$ 'Are the brain, and the moral and intellectual processes known to be associated with the brain, subject to the laws which we find paramount in physical nature?' As if to assert the freedom of the will was equivalent to the denial of such objection! Again, ${ }^{2}$ he says, 'Are we, or are we not, complete masters of the circumstances which create our wishes, motives, and tendencies to action? Adequate reflection will, I think, prove that we are not.' As if any one asserted that we are complete masters, or that it needed much reflection to know that we are not; or as if such knowledge told one iota against the freedom of the will. He then proceeds quietly to beg the question, saying, 'My physical and intellectual textures were woven for me, not by me.' As if the knowledge that they were more or less woven for us was a bar to any co-operation of our own in the weaving process. Lastly, he affirms, 'If finally our motives and wishes determine our actions, in what sense can these actions be said to be the result of free will ?' As if the conceded fact that action is ever determined by some 'motive' was the slightest bar to the action of that power (of the possession of which our consciousness assures us) by which we may voluntarily select a motive less clamorous and less attractive than some other simultaneously soliciting our will.

A few words now as to the consequences of this teaching; not that I do not confidently affirm that truth must be sought and followed, be the consequences what they may, but I do so affirm because I am a theist and an opponent of utilitarianism, and can therefore consistently make that affirmation. It is, however, always fair to argue from utility when arguing with utilitarians, and it may be of service to the cause

${ }^{1}$ P. 608.

${ }^{2}$ P. 609. 
of truth to point out that the absolute desirability of truth cannot logically be an axiom with non-theists. The consequences, then, of the teaching referred to are, it may be with confidence affirmed, simply fatal in their tendency to both morality and freedom, an utterly immoral tyranny being their natural result.

In deprecation of such a judgment as that here recorded, the Professor tells us, (1) that Mr. Holyoake and other nontheists known to him are excellent as fathers, husbands, neighbours, and citizens, free from moral shiftiness, and scrupulously faithful to engagements; and (2) he draws out his own method of dealing with criminal offenders. As to the first point, far from contesting it, it is a great satisfaction to me to be able to quote words of my own of similar effect-words addressed, not to the public of the Nineteenth. Century, but to the most ultramontane class of readers to be found in England. I then said:- 1

'No one has a stronger sense than I have of the estimable qualities of many of our English "advanced" thinkers, both in their civil and in their domestic relations. I have had personal experience of, and bear most willing testimony to, the self-denying philanthropy and purity of life of men whom I cannot claim as brother theists, but to whom for these reasons I cannot but look up with sincere admiration.'

But what valid argument can be drawn from such admission in favour of atheism? The old reply, that existing atheists are the outcome of Christian ancestors and of a more or less Christian environment, obviously accounts fully for such phenomena which should be expected à priori.

Every one knows how much better men often are than their creeds, and there is no more reason to doubt the goodness of life than the honest sincerity of unbelievers. Fully maintaining that atheists generally are not only in error but culpable (though not, of course, necessarily more culpable

${ }^{1}$ Dublin Review for 1876. 
than are many theists whose culpability may have consequences in another department of morals), yet past culpability need not prevent a man from holding his opinions conscientiously now. Again, however bad atheism may be, there is one thing yet worse-namely, a belief in a bad God. Now, surely it is quite conceivable, and there is to my mind evidence of the fact, that some men have been driven into atheism by moral revulsion from the systems in which they have been reared. Amongst my non-theistic friends is one who has ever led a life of the most exceptional purity, the greater part of whose time has for years been passed in active charity-philanthropy being the one aim and object of his life; yet this man is the son of most religious parents, and was carefully trained in early piety, though the Calvinism he was taught ultimately revolted him.

But the Professor's mode of dealing with criminals is very instructive. He represents ${ }^{1}$ 'society' as replying to a criminal who objects to it as follows: 'You punish me for what I cannot help.' 'Granted, . . . but the public safety is a matter of more importance than the very limited chance of your moral renovation.' This is frankly to throw over all considerations of justice, as generally understood by mankind, and is the natural result of denying freedom, and therefore moral responsibility. The position assumed necessarily reduces morals to a matter of taste, tested by utilitarian results, or what are believed to be such, and thus there is not, and cannot be, any true guarantee for the supremely sacred rights of conscience, the liberty of which is the most fundamental and sacred of all liberties. Conscience is that which Dr. Newman has so nobly declared to be 'the aboriginal vicar of Christ, a prophet in its informations, a monarch in its peremptoriness, a priest in its blessings and anathemas, so that even if the eternal priesthood throughout the Church should ${ }^{1}$ P. 612.

VOL. II. 
cease to be, in it the sacerdotal principle would remain and would have sway.' No protest in the name of conscience can logically have weight in the eyes of those who, denying all freedom to the will, deny the very idea of conscience and of right. ${ }^{1}$ And though the deeply planted and instinctive belief in virtue and merit renders it impossible that such protest should fail to arouse the generous sympathies of our fellowmen, yet the tendency of such teaching as the Professor's is to bring back that pagan idea of 'the State,' according to which the individual citizen had no invincibly sacred rights, while the supposed welfare of the community was proclaimed supreme. It should never be forgotten, and least of all in these days, when anti-Christian propagandism is so rife, that it was the Jews and Christians, full of the spirit of enthusiastic and vividly realised theism, who, for the first time, to the amazement of judges who would fain have been merciful, maintained the sacred rights of conscience, and by patient endurance, sufferings, and death vindicated the claim of each individual -not only citizen, but slave-to the freedom of a rational and responsible nature.

Thus it is theism which alone gives a logical basis for really tolerant views based on justice, and a belief in the wonderful dignity of that human nature which has had conferred upon it the divine gifts of reason, free-will, and responsibility. Armed, then, with these truths, we can inexpugnably defend the rights of conscience, we can, in the name and by virtue of moral responsibility, repudiate persecuting intolerance, whoever may be the victims, and, while execrating the horrors of the Parisian Commune, join also heartily in the venerable and universally esteemed

${ }^{1}$ Mr. Martineau has pointed out that according to the view advocated by Professor Tyndall, Mr. Spencer, etc., 'conscience is but a hoarded fund of traditionary pressures of utility.... Our highest attributes are only the lower that have lost their memory, and mistake themselves for something else.' As before quoted, see ante, vol. i. p. 326. 
Bishop Milner's execration respecting the iniquity of St. Bartholomew :-

'Excidat illa dies æro, nec postera credant Sæcula.'

On the other hand, were I myself an atheist, I could not deny the possible advisability of a vigorous persecution of atheism. Did I also hold man to be but an improved ape, I might reasonably maintain the need of a rigorous repression of all practices I disliked, for we should then have no rational ground for confidence that the world was so formed that truth, justice, and virtue must in the end prevail over their various and most discordant enemies.

The system Professor Tyndall advocates he has advocated on the principle of the persistence and transformation of energy, and the ultimate conception presented is that of motion (molar or molecular), as the objective reality underlying those subjective delusions-Human Virtue and Divine Wisdom. But in the first place it is most inconsistent in those who deny to man's soul the power of directly perceiving objectivity, to speak of purely physical changes at all, or of molecular motions as the accompaniments of feeling with which they may be contrasted. Try and conceive such motions as we may, they ever remain (according to their philosophy) but forms of subjectivity - a 'wave motion' can be nothing else than a plexus of sensations past and present. But, putting aside this objection, it may be asked with respect to the attempt to conceive and represent all activities in terms of motion-is not the notion that by thus representing them we get deeper into their real nature than otherwise we should do but a delusion resulting from the facts that motions are our commonest sensible experiences?

It is not that reason tells us that 'motion' is the one ultimate universal and fundamental power or activity, any 
more than 'reason' or 'will.' But our senses induce us to regard it as such, or at least always to seek it, as when in common language we say that a man is 'moved' by a strain of music or 'agitated' or 'shocked.' We cannot well avoid making use of these analogies, and hence arises a prejudice of which the practice just referred to is an ultimate result. Moreover, men of science naturally seek to reduce all phenomena to terms of motion in order to bring them within the reach of mathematics, when they can be so easily and perfectly dealt with.

But let us concede this reduction into terms of motion, let us concede even the whole process of Evolution as understood by its most 'advanced' advocates, and what is the logical result? Not, I take it, quite that which such advocates have had before their eyes. As Mr. Balfour has acutely shown, ${ }^{1}$ if all our beliefs and reasoning processes are but due to the action of the environment, then, since it is manifest that that action results now, and in times past has resulted, in the acceptance of what is not truth, we have no guarantee for the truth of even our fundamental processes of reason, and consequently for the truth of Evolution itself. Moreover, if it is thus doubtful whether we can ever attain truth at all, there is yet a second question to be considered: is truth, under such conditions, necessarily a good?

Some evolutionists, and especially Professor Tyndall, speak of 'truth' as if it was manifestly at all times necessarily a good. We may, indeed, heartily join with them in so proclaiming on the strength of an unequivocal theism, but without that belief, the affirmation seems to be destitute of a aue logical basis. In the first place, what do the gentlemen referred to mean by 'truth,' and what by 'desirable'? Now I suppose that by 'truth' is meant merely the 'general laws of nature,' and not particular truths, as it is manifest that on

${ }^{1}$ Fortnightly Review for November. 
no hypothesis can a knowledge of 'truth,' in this extreme sense, be always desirable. The utility of informing Pitt on his deathbed of the battle of Austerlitz cannot be very apparent, nor probably would any one affirm that to tell any dying man, with no property to dispose of, that the children he loved were not really his, would be a praiseworthy action. Of course we need not suppose that our friends who are so zealous for truth would go to this extreme, and yet the language used has sometimes been so strong as almost to justify the inference that they would do so, and to imply the existence of a sort of superstitious awe, as if truth was something almost supernatural. Yet 'truth' is but a relation of conformity between mind and objective existence, and if objective existence happens to be itself undesirable, can mental conformity to it be always the reverse? But granting that by 'truth' is meant scientific truth only-a knowledge of the facts of nature and her laws-what is meant by 'desirable'? That is surely 'desirable' which each man desires, and most men desire their own well-being, and that of those they care for. Now it is not difficult to imagine cases in which some people might not think a knowledge of certain scientific truths, such as those of toxicology, 'desirable' for the sharers even of their bed and board.

But it will probably be replied that 'desirable' mean̂s 'desirable for the human race'; and we may therefore proceed at once upon the amiable fiction, that the one supreme desire of the mass of mankind is the welfare of the race, and that there are really very many good enough to agree with Mr. Harrison in really caring about remote generations, existing in æons of time after they (if the hypothesis I am considering is right) have faded into what science, as opposed to rhetoric, must, instead of 'infinite azure,' call 'very finite mud.' Moreover, on the conscious-automaton hypothesis, a knowledge of truth or falsehood, being a state of conscious- 
ness, must be indifferent, since, upon that view, it can have no influence upon action, but is a mere concomitant. How then can a knowledge of the facts of nature be a cause of welfare to mankind?

Waiving this objection, it seems to me demonstrable that without theism we have no certain ground for affirming the necessary universal goodness of truth, for without theism we have no certain ground for affirming that the objective world and its laws are good, while there is much apparent evidence the other way. As a naturalist, I cannot but think that, apart from the postulate referred to, nature presents many blots, or, to say the least, very doubtful puzzles; and as to history, we may appeal to Mr. Leslie Stephen as a witness against extreme optimism. Even as regards the future of our own species, it is surely conceivable that it may be with the race as with the individual, and that the environment may be so conditioned as to make the extinction of the one, as of the other, merely a question of time; and such, certainly, would be the anticipation of most evolutionists. If, then, a complete mental conformity to the environment, a thorough knowledge of actually existing circumstances, may be prejudicial to the individual, and accelerate his extinction (and such cases might be easily imagined, had not so many suicides demonstrated the fact), what certain guarantee can we have that it could never be so for the race? Moreover, if the views of our friends of the opposite school were correct, and freedom of will and responsibility were but unmeaning words, it seems to me impossible not to question whether a general knowledge of the fact would be desirable. That degree of civilisation and improvement which has been attained by men has been attained on the supposition of their reality; may not, then, retrogression accompany the overthrow of such belief? Would not the universal realisation (were that not happily impossible) of determinism, tend 
to paralyse moral effort on critical occasions? I am persuaded that it would; but however that may be, one thing is certain. Since the belief in responsibility has been hitherto generally accepted and acted on, this fact alone constitutes a sufficient proof, for those with whom I am arguing, that the delusion was beneficial for the race, since they must admit that otherwise it could never have arisen through the survival of the fittest. In harmony with this view, Mr. Herbert Spencer fully admits that a society or nation may get free of its faith too easily for its own safety. How then can it be certain that it may not be the same for the whole human race?

If the doubts here expressed are well founded, there would surely be much wisdom in the saying attributed to Voltaire, 'Si Dieu n'existait pas, il faudrait l'inventer'; and it appears to me that the philanthropist who declines the postulate here advocated should pause before propagating his negative convictions. It may, to say the least, be far more philanthropic in such a one, instead of seeking to tear down systems the congruity of which with human welfare experience has demonstrated, to select from amongst what he deems the mythologies of his day, that which he considers the most calculated to promote human happiness, and to, more or less, energetically support it. I think I hear the indignant protests of some utilitarian and non-theistic friends at the 'immorality' of such a doctrine. Though it is impossible not to smile at the logic of such protesters, I should be the last to refuse them a tribute of warm admiration for their rectitude of sentiment, showing as it does, yet once again, how much better than their creeds good men may be; and yet, if that is 'moral' which 'tends to increase the happiness of men,' how can that be 'immoral' which ex hypothesi has that very tendency? Appeal may be made, however, to the authority of writers whom our opponents 
will not fail to respect. Mr. Bain, ${ }^{1}$ after speaking of the general importance of truth, adds, 'We are not surprised if an element of such importance as a means should be often regarded as an absolute end to be pursued irrespective of consequences ' ${ }^{2}$ and Mr. Mill, in his essay on the utility of religion, proceeds throughout on the principle that truth is valuable only for its utility.

As to the general utility of truth, there can of course be no question, any more than that the love of it ought to be an all-powerful sentiment. But I go further than this, and in common with all those who accept the theistic postulate, can logically, as well as heartily, affirm, however perplexing may be the aspect of the universe, that it must yet be good, and that the most complete knowledge of truth must be desirable for mankind.

In conclusion I would venture to urge that Professor Tyndall's teaching, the tendencies of which may, I believe, be so justly deprecated, largely reposes on the denial of the distinctness between diverse physical powers or activities, on the strength of their quantitative equivalence, and on the presentation of force (or energy) as a persistent real substance, which eternally ebbs and flows through a world of sensible phenomena (amongst which phenomena we ourselves are ranged), while the ebbing and flowing substance is represented as really constituting that which we mistakenly consider our consciousness, our reason, and our will.

Such teaching is but a supreme application of the doctrine of the persistence and transformation of force (or energy) which, as expressing the quantitative equivalence of activities, is indeed an important truth, but which in the sense too often apprehended, I cannot but deem a misleading superstition. It is a superstition which cannot be too soon

1 Mental and Moral Science, p. 106. See also pp. 359 and 444.

2 Pp. 73 et seq. 


\section{Force, Energy, and Will}

eliminated through the careful selection by physicists of expressions which do not go beyond, or inculcate more than, those facts for which we have indisputable scientific evidence. The result of such selection would be the introduction into common speech of phrases and expressions consistent with true ideas about nature and the quantitative equivalence of its activities, and the elimination of other phrases and expressions which imply false ideas and beliefs, such as the idea of and the belief in the existence of one persistent and self-transforming universal and substantial force. 


\section{LIKENESSES ; OR, PHILOSOPHICAL ANATOMY.}

TO say of any man that ' he does not know a hand from a foot' is to state that his power of estimating difference is defective in an extreme degree, and this statement also seems to imply that such defect is even more remarkable than would be its opposite-namely, a failure in apprehending the likeness which exists between those two parts. Indeed, to pass from a recognition of such unlikeness to an apprehension of such likeness-or, as it is called, 'Homology'-is to make a step in advance. Our appreciation and comprehension of the world around us is but a continued repetition, on an ever-widening scale, of similar successive processes of analysis and synthesis. In each branch of science, along with our keener and keener perception of differences, we come to perceive more and more recondite relations of agreement. The telescope and the microscope, the chemical laboratory and the dissecting-room, at first enable us to detect more and more hidden differences in sidereal masses, in animal tissues, in atomic relations, and nerve distributions. Yet, afterwards, the very same agencies enable us to discover facts which tend to harmonise in corresponding unities the previously discovered diversities of nerve distribution, of chemical relation, of histological condition, and (by spectrum analysis) of sidereal constitution.

In however many directions the human mind sends forth its energy upon surrounding nature, its activity brings just 
so many vistas of agreement underlying difference before its ken. Indeed, as Mr. Lewes says, ${ }^{1}$ with, perhaps, some exaggeration of expression: 'Science is in no respect a plain transcript of reality ... but .... an ideal construction in which the manifold relations of reals are taken up and assimilated by the mind, and there transformed into relations of ideas, so that the world of sense is changed into the world of thought.' And again he declares:2 'What we call laws of nature are not objective existences, but subjective abstractions.' We say these expressions are somewhat exaggerated, because that which is the product of the 'manifold relations of reals' must have some real foundation and some objective validity in the eyes of those who admit, as it seems Mr. G. H. Lewes does not, the real and known existence of an external world of more than mere feelings. Any one who admits such existence must also admit that the various ideal entities which are ultimately justified to reason as true ideals have their foundation in their agreement with real objective existence, 'truth' being a relation between 'Being' and an 'Intellect.'

The various groups into which animals and plants have been divided are of this nature-i.e. are ideal entities with an objective basis. Classes, orders, families, genera, and species exist as such only in a mind. Objectively, there is nothing but individual animals and plants. Nevertheless, the different biological groups also exist objectively in those facts of structure which various individual animals and plants present, and which serve for the definitions of such different groups. What Mr. Lewes says ${ }^{3}$ of certain other abstractions applies here with perfect correctness: 'They are realities in the sense of being drawn from real concretes; but they are not realities existing apart from their concretes

1 Problems of Life and Mind, vol. i. p. 342.

${ }^{2}$ Op. cit., p. $297 . \quad{ }^{3}$ Op. cit., p. 281. 


\section{Likenesses; or, Philosophical Anatomy}

otherwise than in our conception; and to seek their objective sub-stratum, we must seek the concrete objects of which they are the symbols.'

Natural classification, indeed, though formed by the mind, does not depend on the mind. It is not arbitrary, but is governed by the external realities of things. It is not that we choose to separate bats and whales from birds and fishes respectively, and put them both in the same class as that which contains also the lion and the antelope. We are compelled, by the multitudinous facts of animal structure, so to separate and so to class them. Moreover, such zoological classification is only possible because different animals are found to have like parts (parts alike as to their relations of position to other parts) which can be compared and contrasted, and can, by the agreements and differences they present, furnish us with the determining and limiting characters of the different natural groups.

As it is with respect to the various groups of animals and plants, so it is with respect to the parts and organs which together compose each individual animal or plant. As the human mind surveys these parts and organs in different lights, it finds different series of unlikenesses and likenesses, extending along that line of thought which it elects to follow. Here again, however, the resulting groups of likenesses cannot be freely and arbitrarily established, but must follow objective reality. It is thus that fanciful notions which do not respond to the realities of things, have to succumb and give place to conceptions which do harmonise with such realities.

Every bird and beast, every fish and insect, is formed of a complex aggregation of parts which are grouped together into an harmonious interdependency and have a multitude of relations, amongst themselves, of different kinds. The mind detects a certain number of these relations as it contemplates the various component parts of any individual 
animal in different ways-as it follows up different lines of thought.

These perceived relations, though subjective as relations, have nevertheless an objective foundation in real parts, or conditions of parts, of real wholes, and it is their correspondence with such objective foundations which gives to ideal relations whatever truth they may possess. To detect the most hidden laws of unity underlying the differences presented by animal structure, is the work of 'Philosophical Anatomy.'

Speculative and creative minds, imbued with natural knowledge, have pursued with avidity this kind of inquiry. While more ordinary minds have been content with observing the facts of animal structure, nobler minds have ever tried to solve the problems of the 'how' and the 'why.'

An inquiry of this kind into the nature of the skeleton is the anatomical question which has specially occupied Goethe, Oken, Spix, Carus, De Blainville, Geoffroy St.-Hilaire, and Owen. It may not be uninteresting to consider whether the attempt to solve such problems is, as so many persons have come to believe, an altogether vain one, and if it does not appear to be a vain pursuit, then to inquire what is the nature of the answer which reason and observation combine to furnish.

By a singular coincidence, the casual finding of the mutilated skull of a Ruminant helped to evolve, independently, from the minds of Goethe and of Oken, full and distinct conceptions of a new theory of the bony framework of the head. Each of these thinkers conceived the idea that the skull, instead of being (as had been universally supposed) an altogether peculiar structure, was in reality similar in composition to the backbone, or spinal column. The backbone is made up of a series of rings of bone mutually adjusted, called vertebræ. Goethe and Oken conceived that 


\section{Likenesses; or, Philosophical Anatomy}

the skull was also made up of a series of vertebræ-much altered, however, as to size and shape, from those which form the spinal column. This idea, once emitted, was rapidly taken up by Oken's countrymen (as at later periods they have vehemently taken up the ideas of Schwann and of Darwin); and Spix, Bojanus, and C. G. Carus further developed and modified the original idea. Nor did Oken's countrymen by any means stand alone, for De Blainville and Geoffroy St.-Hilaire in France, and Goodsir, Maclise, and Owen in the British Isles, more or less accepted and modified, in different ways, the hypothesis propounded. Oken, indeed, at once pushed his speculation to extremes: expecting, on $\grave{a}$ priori grounds, to find the whole trunk, with its appendages, represented in the head. He was by no means content with assimilating the skull to the backbone, but insisted on finding the arms and legs, the hands and feet, even the fingers and toes, of the head; imagining that the last mentioned members (fingers and toes) were represented by the teeth! Such a conception may be taken as a good example of those fanciful notions before referred to, which, not being sustained by objective facts, are surely destined, as was this, to die out and to disappear.

The vertebral theory of the skull, in an amended form, became widely known in England through Professor Owen, and anatomical science in this country will ever be very deeply indebted to him for his attempt to familiarise the English mind with 'Philosophical Anatomy,' since all must at least admit that it has brought about an important scientific advance, through the efforts it occasioned to support, to modify, or to refute it. According to Professor Owen's hypothesis, the skull of every backboned animal, from man to the cod-fish, was really made up of four modified vertebræ, each being provided with an inferior arch, like those which in the trunk are formed by the ribs. The 
skeleton of every existing vertebrate animal was represented as being formed from some modification of an ideal archetypal skeleton, which was again represented as composed of a series of ideal archetypal vertebræ. This notion for a time net with very general acceptance, but was, ere long, attacked, especially by Professor Huxley, as being inconsistent with the facts of development. It was said that if the skull was made up of modified vertebræ, its vertebrate character should be plainest in its earliest and least modified stages; and that yet such stages had no resemblance to vertebræ at all. Indeed, it was triumphantly shown that, as soon as the backbone begins to be a backbone, the skull begins to be something very different. It was shown, in fact, that the skull is never segmented, as is the primitive vertebral column, but mainly consists, in its earlier stage, of a mass of cartilage, from which two cartilaginous rods (the trabecula cranii) extend forwards along the base of the brain case quite unlike anything found in the incipient vertebral column. Yet other suggestions were made by Professor Seeley and by Mr. Herbert Spencer, to account mechanically (by the necessary action of pressures and strains on a frequently flexed elongated cylindrical body) for the simultaneous existence of a segmented backbone and a non-segmented skull. Finally, a flood of ridicule and sarcasm was poured on the vertebrate theory of the skull, and the doctrine of archetypal ideas was supposed to be once for all disposed of by means of the hypothesis of evolution. Mr. Darwin's Natural Selection was lauded as having given the coup de grace to such fancies; and, lastly, appeared 'Pangenesis,' to slay the slain, and to make fortuitous compounds of atoms occupy the vacant thrones of the deposed prototypal divine ideas. Evolution seemed to so many persons to have this destructive effect because by and through it similarities existing between the parts of different animals came to be represented as exclu- 


\section{Likenesses; or, Philosophical Anatomy}

sively due to blood-relationship between them. It was no longer a wonder that the skulls of a monkey and a mud-fish were essentially similar, if both these animals were the diverging descendants of some ancient common ancestor.

A distinction had long been recognised, had been plainly put forth by Professor Owen, between parts which resemble each other in their function-analogous parts-and parts which resemble each other in their position with regard to neighbouring bodily structures-homologous parts. The wing of the humming-bird and the wing of the hummingbird hawk-moth are analogous parts-they perform the same function-as, in a less perfect degree, does the parachute of the little lizard (Draco volans). But the bones which sustain that parachute, and the ribs of the humming-bird are homologous parts-i.e. they have similar relations of position to neighbouring bodily structures. The parachute-bones and the wing-bones, on the contrary, are analogous parts. Such facts of 'homology' had been deemed deep mysteries. No d priori reason could be given why animals of the most different modes of life should have been formed on similar patterns. The man, the horse, the whale, and the bat, all have the pectoral limb-whether arm, fore-leg, paddle, or wing-formed on one type, diverse as are the uses to which these limbs are applied. Again, the butterfly and the shrimp, different as they are in appearance and mode of life, are constructed on one common plan, of which they exhibit diverging manifestations. These facts were recognised as facts, though no explanation of them could be offered. But they became readily explicable on the assumption of a bloodrelationship, through actual generation and descent from common ancestors. Here, then, appeared to be the end of mystery with respect to homology - a ready, clear, and sufficient explanation seemed to have been supplied. A new definition of homologous parts thus suggested itself. They 
might be simply described as parts which resembled each other, because they were alike descended from one single part in a remote common ancestor.

Soon, however, investigation rendered necessary further analysis, with respect to parts said to be homologous. It came to be recognised that there are likenesses between different animals and different parts of the same animal, which a theory of common descent cannot explain; and 'similarity in relative position' had to be once more had recourse to as a definition of what was meant by homology, such similarity being, in certain cases, explicable by 'descent,' and in others not so explicable.

A very obvious example of likeness not explicable by 'descent' is the familiar one referred to in the early part of this paper, between our right hand and our left. This likeness is part of that general correspondence which exists between the right and left sides of most animals, and which is spoken of as 'bilateral symmetry,' or lateral homology. Another example is that likeness which sometimes exists between parts placed one above another, as between the upper and lower parts of the tail-fin of most fishes. Such likeness is an example of 'vertical symmetry,' or vertical homology. Another kind of 'likeness,' or homology, is termed 'serial.' It is chiefly in our limbs that this kind of homology is manifested externally in us, but it is plainly enough to be seen in the human skeleton (or in that of any backboned animal), in the ribs or in that series of generally similar bones (vertebræ) which make up our vertebral column or backbone. Our limbs, however, as was said at the outset, do present, even externally, a certain degree of similarity, the thigh, leg, and foot of the lower limb evidently more or less repeating the upper arm, arm, and hand of the upper limb.

Mr. Herbert Spencer, in his First Principles of Biology, vOL. II. 
attempts to explain these and all facts of structure, not due to inheritance, by the action upon each organism of its environment. Thus he explains the very general absence of symmetry between the dorsal and ventral (upper and lower) surfaces of most animals by the different conditions to which these two surfaces are respectively exposed. But it may be objected that this is no real explanation, but a mere restatement of the facts. No reasons have been given by him showing either how or why each organism so responds to such external differences of environment, or how such differences of environment tend to produce such particular modifications. Mr. Spencer, indeed, beautifully illustrates that correlation which, however produced, all must admit to exist between the structure of organisms and their surrounding conditions, but he quite fails to show that such conditions are the cause of such structure. His argument is, indeed, an example of the old fallacy, post hoc ergo propter hoc. We believe the cause to be, not external, but internal. If animals and plants respond so readily to the action of external incident forces, it must be the case that conditions exist in such animals and plants which dispose and enable them so to respond, according to the maxim, Quicquid recipitur, recipitur ad modum recipientis, as the same rays of light which bleach a piece of silk blacken nitrate of silver. If, therefore, we attribute the external forms of organisms to the action of external conditions, we but remove the difficulty a step back, since we must conceive an internal power and tendency occasioning such ready modifiability of structure. But, indeed, it is not at all easy to see how the influence of the surface of the ground, or any conceivable similar external condition or influence, can produce such differences as those existing between the dorsal and ventral shields of the carapace of a tortoise.

The likenesses, then, which exist between arm and leg, 


\section{Likenesses; or, Philosophical Anatomy}

and between hand and foot, are hardly to be explained by $L$ any mere action of the environment. But serial homology is much better exemplified in a very different group of animals from backboned creatures-namely, in that group to which all insects, lobsters, centipedes, leeches, and earthworms belong-the group of Annulose animals. In the centipede, the body (except at its two ends) consists of a longitudinal series of similar segments. Each segment supports a pair of limbs, and the appendages of all the segments (except at each end of the body) are completely alike. In most other creatures of the Annulose group, the fundamental similarity between the successive segments of which the body is composed, is more or less disguised. Thus, for example, in the lobster, a number of the anterior segments of the body are united together into one solid mass, while only in the abdomen (the so-called tail) do the segments remain distinct. The limbs also, which at first are all similar, assume, with the development of the young lobster, different forms, and become respectively antennæ, jaws, claws, legs, and swimming-feet. The peculiar and strongly marked serial homology of these Annulose animals has been the subject of an exceedingly ingenious suggestion by Mr. Herbert Spencer. In his work just referred to, he has attempted to explain such serial homologies thus:Some animals of a very low grade propagate themselves by spontaneous fission-one individual spontaneously dividing, and so becoming two distinct individuals. If certain creatures found benefit from this process of division remaining incomplete, they would (on the theory of 'Natural Selection') transmit to their posterity a naturally selected tendency to such incomplete division. It is conceivable that certain animals might thus have come to assume the form of a chain of similar segments-i.e. a chain of imperfectly separated individuals. Such a chain would, of course, in one kind of 
animal be the equivalent of a series of perfectly separated individuals of another kind of animal in which the process of fission was completely carried through. In other words, Mr. Spencer would explain the serial homology of Annulose animals by the supposed coalescence (through imperfect fission) of organisms of very simple structure, such as the small aquatic worms called Planarice, in one aggregated longitudinal series through the survival of the fittest aggregation. This is a very ingenious speculation, yet there is positive evidence which directly conflicts with Mr. Spencer's hypothesis. Mr. Mosely, in his investigations of the land Planarice of India, has brought forward evidence that a single Planaria is the equivalent not of a segment of a leech but of a whole leech. Yet a leech is the morphological equivalent of a whole centipede, lobster, or other higher Annulose animal, and therefore each higher Annulose animal must be regarded as itself a morphological unit, and not an aggregation of such units.

Moreover, even lateral, vertical, and serial homology do not exhaust the kinds of likeness (homologies) which have arisen independently of descent. For structures are continually being discovered (in animals of different kinds) so strikingly alike that their resemblance would naturally be taken, on the theory of Evolution, for a sign of genetic affinity, and yet the circumstances under which they occur preclude any such explanation. The resemblance which exists between the ankle bones of such widely different animals as frogs, and the small African lemurs, termed Galagos, may be taken as an example of such uninherited likeness. In a genus of the frog order (namely Pelobates), and in the turtle, a bony expansion covers over that hollow at the side of the head which is called the 'temporal fossa.' A similar expansion has lately been found to exist in a certain African animal of the rat order (namely Lophiomys), 
though it exists in no other known beast. The resemblance which exists between Pelobates, the turtle, and Lophiomys must be supposed to have been occasioned independently, and not by inheritance. Again, the African ant-eater, the aard-vark (Orycteropus), has each tooth, though apparently simple, really composed of a closely set bundle of very fine, long, cylindrical teeth united together side by side. Such a structure exists in no other genus of the same class, but is found in the class of fishes-namely, in the skate (Myliobutis). Yet the aard-vark can have no special relation of genetic affinity with these fishes. The shape of the teeth in kangaroos is similar to that of certain shrew-like, insecteating African beasts (of the genus Macroscelides), which also agree with kangaroos in having the hind-legs and feet much elongated and a jumping mode of progression; yet this double similarity is almost evidently induced and not inherited. The only beasts of burthen known in South America when it was discovered by the Spaniards, were the llamas, animals which present a singular structure as to the course of their vertebral arteries, which pierce the neck-bones on their inner sides. The very same condition, however, occurs again in the great ant-eater, also an inhabitant of South America. Yet it is impossible to believe that any special affinity, through descent, can connect such strangely divergent forms. It is also noteworthy that this character can hardly have been due to any action of 'natural or sexual selection.' The examples cited are but a few of inany which might be adduced as evidence in this matter.

It has then been forced upon our attention (alike by the facts of lateral and serial homology, as well as by such as those just cited) that there are likenesses or homologies which cannot be due to inheritance, and which have to be distinguished from others which are, or which may be, so due. With the new mental conception came, as was fitting, 


\section{Likenesses; or, Philosophical Anatomy}

the new oral expression. We have to thank Professor Ray Lankester for the introduction of the terms 'homoplasy' and 'homoplast,' to express such uninherited resemblance and such resembling parts, as well as for the antithetical terms ' homogeny' and 'homogen,' to express inherited resemblance and the parts which manifested it.

For our part, experience more and more convinces us that the number of similarities which have arisen independently (i,e. cases of homoplasy) is prodigious, as well as that very great caution is needed in endeavouring to discriminate between likenesses which may be due to inheritance, and those which are due to some other cause. The wonderfully minute, exact, and elaborate investigations of the first of our English embryologists (the late Professor Parker) constantly made manifest the existence of an apparently inexhaustible number of complex cross relations between widely different animals, and show more and more plainly the entangled interdependencies of their structure. The notion, once popular with evolutionists, that 'similarity of structure' necessarily implies 'genetic affinity', can certainly now be maintained, as a biological axiom, by no well-informed naturalist.

Indeed, the distinction between homogeny and homoplasy (between the influence of a common descent and that which produces independent similarity) has its importance much reduced through the power which the latter possesses of simulating the former. The degree to which homoplasy can rival homogeny in the degree of likeness produced, is shown, not only by the instances cited, but also by the likenesses existing between some of the bones of the skull in beasts and in osseous fishes. Probably but few naturalists would now dispute the independent origin of the bones of the skull in those two classes of animals. Yet their cranial bones are in many instances indisputably homologous, 


\section{Likenesses; or, Philosophical Anatomy 263}

while in others their homology is a subject of keen discussion.

If it be asked what is meant by parts being ' homologous' if they are not 'homogenetic,' it may be replied that it means they show a complex likeness, or agreement, as to their relative positions to other surrounding parts. This likeness, or agreement, may be of different kinds, according as we follow different lines of thought. An intellect of a higher order than that of man would probably detect an indefinite number of relations between two animals and between their component parts, which relations escape our observation altogether, though we can readily enough apprehend a considerable number of such relations.

Thus we may enumerate as examples of different kinds of homology :-

1. Parts which have a similarity of function but differ structurally and in their relations of position to all the other portions of the body - e.g. the legs of a lizard and of a lobster.

2. Parts which are similar both as to function and relative position-e.g. the wings of a bat and of a bird.

3. Parts which, upon the hypothesis of evolution, are descendants of some ancient similar structure-e.g. the arm and leg bones of the horse and of the rhinoceros.

4. Parts which are similar as to their mode of origin in the individuals compared, whatever be their racial genetic relations - e.g. the occipital skull bones of a panther and of a perch.

5. Parts which are alike but which do not arise similarly in the individuals compared, whether or not they are the descendants of parts in some one common ancestral forme.g. the legs of different kinds of flies - these insects differing strangely in their modes of attaining their adult structure.

6. Laterally homologous parts. 
7. Vertically homologous parts.

8. Serially homologous parts.

(These last three kinds of homology have been already sufficiently explained.)

9. Parts of the same individual which have a certain likeness and correspondence though placed at opposite ends of the body-e.g. buccal and anal chambers.

10. Parts of one individual which repeat each other and which radiate from a central point-e.g. any two arms of a star-fish.

11. Parts which agree with each other as being successive subdivisions or segments of some part or organ-as of a limb or insect's feeling organ (antenna) -and which are thus serial homologues of a subordinate kind, or subordinate serial homologues.

12. Parts of such subordinate serial homologues, which parts stand to each other in a secondary serial relation, as, for example, does the root segment of the leg of a lobster to the root segment of one of its swimming appendages.

13. Parts which stand to each other in a tertiary serial relation, as being annexed to such subordinate serial homologues as stand to each other in a secondary serial relation.

14. Special homologues which are parts existing in different animals, but belonging to the same special skeletal category -as, e.g., the nail of a man's middle toe and the hoof of a horse.

15. General homologues, which are parts belonging to the same general skeletal category-as, e.g., when we say of a part that it is a limb, or of another that it is a rib, or of a third that it is a vertebra. We may distinguish, then, different kinds and degrees of relationship, which are severally perceived according as the mind is directed along one line of inquiry or another, and whether concerning different individuals or different parts of the same individual. 
Now, we contend that it is against reason to suppose that mere indefinite variation, together with the 'survival of the fittest,' could ever have built up all these serial, lateral, and other homologies without the action of some innate power or tendency so to build up, possessed by the organism itself in each case.

What can be more wonderful than the symmetry of those lowly but beautiful organisms, the Acanthometrce, a symmetry for which it is difficult to conceive any external cause?

Hardly, if at all less wonderful, is the radial symmetry of the Echinoderms (the sea-stars, sea-eggs, and sea-urchins) with their multitudinous variety of component parts. If, then, internal forces can build up such varied structures as these, they may well be also capable of producing the various serial, lateral, and vertical symmetries which higher animals exhibit.

We may next consider whether there are not other external evidences (besides the homologies themselves) of the existence of such an internal power, by the action of which these recondite 'likenesses' may be conceived to be brought about. It is here contended that there is good evidence of the existence of some such special internal power, which evidence may be gathered from three sources: 1, Comparative anatomy; 2, the science of monstrous births, or teratology; and 3 , the science of diseased structures, or pathology.

First, as to comparative anatomy, one example may be selected where others can be easily adduced, if required.1

On the hypothesis of evolution, tortoises must be reckoned as very far indeed from being the first and earliest kinds of quadrupeds. Yet certain tortoises exhibit the most extraordinary resemblance and correspondence between their anterior and posterior limbs. This degree of likeness and

${ }^{1}$ For others see Genesis of Species, chap. viii. 
correspondence, then, must be the effect of a spontaneous development, and cannot be merely due to inheritance, because it does not exist in other forms which, upon evolutionary principles, are more nearly related to the hypothetical root-forms.

As to teratology, it is notorious that serially homologous parts tend to be similarly affected-great toes sharing abnormalities of structure with thumbs, and ankles with wrists, knees with elbows, and so on. Professor Burt Wilder has recorded six cases in which both the little fingers and both the little toes were similarly affected, and one case in which serial symmetry was alone exhibited, the right little finger and the right little toe being the only ones affected. But perhaps the most curious and instructive instances are those in which the feet of pigeons or fowls are abnormally feathered, or, as it is termed, furnished with 'boots.' These extra feathers are developed along the very parts of the foot which correspond to (i.e. are serially homologous with) those parts of the bird's hand which bear the wing-feathers, so that these 'boots' are plainly a serial repetition of the true wingfeathers. These foot-feathers have, indeed, been sometimes known to exceed the wing-feathers in length. Moreover, these foot-feathers resemble the true wing-feathers in structure, and are quite unlike the down which naturally clothes the legs of such birds as grouse and owls. But there is a more striking correspondence still, for in pigeons which are thus 'booted' the two outer digits (toes) become more or less connected by skin, as is also the case with the corresponding digits of the pigeon's hand.

As regards pathology, Sir James Paget has declared, speaking of symmetrical diseases, that 'a certain morbid change of structure on one side of the body is repeated in the exactly corresponding part of the opposite side'-i.e. we have a spontaneous manifestation of lateral homology. In 
the pelvis of a certain lion affected with a kind of rheumatism Sir James remarked a deposit which had formed a pattern more complex and irregular than the spots upon a map, while not one spot or line on one side failed to be represented with daguerreotype exactness on the other. $\mathrm{He}$ also considers that parts which are serially, as well as those which are laterally homologous, are likely to be affected in a similar manner. Such serially homologous parts are the back of the hand and the corresponding surface of the foot, and these are likely to be both modified in the same manner, as also are the palms and soles, the elbows and knees, together with the other serially corresponding parts of the arms and legs.

What explanation can be offered of these phenomena? To say that they exhibit a 'nutritional relation,' brought about by a 'balancing of forces,' is but another statement of the fact, and affords no explanation of it whatever. The changes are, of course, brought about by a 'nutritional' process, and the symmetry is undoubtedly the result of a 'balance of forces'; but to say so is to affirm a truism. The question is, What is the cause of this 'nutritional balancing' ? It seems impossible not to concede the existence of an internal force. If this power be referred, as it seems $\mathrm{Mr}$. Spencer would refer it, to certain physiological units of which he imagines each organism to be composed, it must none the less be recognised as an innate power, possessed by such units, of inheriting the effects of ancestral modification. It is not easy to see the advantage of Mr. Spencer's reference. It seems easier, simpler, and more consonant with known facts, to recognise in each organism as a whole (which is visibly a unity) an innate power, tending to development of a special kind, though the actual results of the developing force must be modified by the external conditions which happen to exist in each case during the process of development. 
Amongst the results of the recognition of such innate powers and tendencies are an increased support to Teleology and a rehabilitation of 'Philosophical Anatomy.' With such recognition, indeed, it is much less difficult, than without it, to conceive (if 'purpose' in nature be recognised at all) that results which become manifest only at last, and after complex changes which do not seem to foreshadow them, may have been latent and pre-ordained from the first.

When 'Philosophical Anatomy' fell in general esteem, in the manner already related, it did not fall alone. Teleology - or the doctrine of final causes-had been a favourite subject with Professor Owen; and with Teleology, the doctrine of Evolution appeared to many to wage a battle $\dot{a}$ outrance. It was not that this or that explanation was disputed; but the whole conception fell into utter disesteem, and the 'purposelessness' of the organic world (which became with some persons almost an article of faith) has come to form a special branch of study, with its special scientific title of ' dysteleology.'

This materialistic and atheistic spirit of negation has been, however, modified, and seems destined to be more affected hereafter, by that very study which at first came so aptly to its aid.

The further prosecution of embryological research, seemingly so fatal to 'Philosophical Anatomy' in its earlier form, is calculated to have this anti-materialistic effect. The mazy complexity of development changes, the half-revealed affinities, thus seen to radiate in all directions, have convinced more than one of our most eminent observers that no series of haphazard changes is thus offered to their ken, but that they have before them the evidences of an orderly and predetermined evolution. One such observer, at least, has been thus turned from crass materialism, if not to theism, yet to the belief in a Pantheistic Demiurge ever weaving 
Protean matter into structures, the cross relations and affinities of which are too complex for the sharpest of human observers to unravel. Thus, time has brought about strange changes.

'Jam redit et Virgo, redeunt Saturnia regna.'

From the same professional chair whence Professor Owen, in 1849, promulgated his views as to 'Philosophical Anatomy,' his unwearied opponent, Professor Huxley, in 1870, gave out in turn his quasi-vertebral theory of the skull, followed four years later by Professor Parker. Moreover, Professor Huxley has not only eloquently proclaimed the complete compatibility of 'Teleology' with 'Evolutionism,' but even the utter impotence of the latter to weaken, in however small a degree, the position of the teleologist. If such results are admitted by those who are at once zealous evolutionists and eminent advocates of the supreme importance of the study of development, they may well be yet more apparent to those who, on principle, deny that the study of development is the one key whereby may be unlocked the mysteries of animal organisation. Useful, highly useful in its degree, as is the study of development, its importance seems to us to have been of late somewhat over-estimated. For, in the first place, it is manifest that if our embryological researches be carried back as far as possible, we shall not find in the incipient germ any available characters at all, while at later stages diversities in the interpretation of nascent structures are almost always possible. In backboned animals, when the skull begins to assume the consistence of cartilage, the meaning of the initial changes of that process must be elucidated through the changes which take place at subsequent stages. Thus Professor Huxley has lately ${ }^{1}$ testified, referring to the development of the skull of the American gilled-eft Meno-

${ }^{1}$ See Proceedings of the Zoological Society for 1874, part ii. p. 199. 
branches, that, in his opinion, 'no definite answer can be given' to the question whether the trabeculæ 'grow into adjacent tissues, as a tree pushes its roots into the soil,' or whether their apparent extension does not 'arise rather from a chondrification of the pre-existing tissue in the immediate neighbourhood of the trabecular cartilage?'

Secondly, when ossification begins to set in, the meaning of the several ossific centres as they arise must be interpretated by their later stages, or subsequent adult conditions in the same animal or in other animals. How else could epiphyses ever be discriminated from other ossific centres? Again, the circumstance of a bone or cartilage making its appearance as a single element may in any case be due to the junction of its incipiently distinct parts at a period anterior to possible observation-in other words, it may be made up of parts which are called connate-i.e. never distinct to observation, though judged from analogy to be essentially multiple. Of such rationally inferred but invisible distinctness botany offers us a multitude of examples. The stages passed through by the larvæ of moths and butterflies throw but a doubtful light on their adult condition; and what misleading ideas might not be suggested by the development of the Sitaris beetle? This insect; instead of at first appearing in its grub stage, and then after a time putting on the adult form, is at first active and furnished with six legs, two long antennæ, and four eyes. Hatched in the nests of bees, it at first attaches itself to one of the males, and then crawls, when an opportunity offers, upon a female bee. When the female bee lays her eggs, the young Sitaris springs upon them and devours them. Then, losing its eyes, legs, and antennæ, it sinks into an ordinary grublike form, and feeds on honey, ultimately undergoing another transformation, re-acquiring its legs and antennæ, and emerging a perfect beetle. Surely the results of develop- 
ment are as much to be considered as are its earlier stages. We are far indeed from denying that the study of embryology is of great importance, that the investigation as to 'how things become' is a most interesting and valuable inquiry; but we deny that it is all-important. ${ }^{1}$ Aristotle declares the essence of a thing to be 'what it is to be,' and the outcome of development is, to our mind, the important matter. If the apes of the old world, and of the new, have descended from radically different stocks, are they on that account not to be classed together as apes? If it turns out that birds have come, not from one but several distinct reptilian sources, are they not all just as much and as truly 'birds' for all such divergence in origin?

Our view as to each organism is, that it is, dynamically considered, a single form or force, which the human mind is unable to thoroughly comprehend and appreciate. Partial apprehensions of it are to be obtained by different modes of

1 The widespread tendency now existing to sacrifice other and more important considerations to considerations as to origin, is noted by $\mathrm{Mr}$. Morley, in his work on Compromise, 1874. He tells us (p. 23) : 'Curiosity with reference to origins, is for various reasons the most marked element among modern scientific tendencies. . . . Character is considered less with reference to its absolute qualities, than as an interesting scene, strewn with scattered rudiments, survivals, inherited predispositions. Opinions are counted rather as phenomena to be explained than as matters of truth or falsehood. Of usages we are beginning, first of all, to think where they came from, and secondarily, whether they are the most fitting and convenient that men could be got to accept. In the last century, men asked of a belief or a story, Is it true? We now ask, How did men come to take it for true? In short, the relations among social phenomena which now engage most attention are relations of original source, rather than those of actual consistency in theory, and actual fitness in practice. The devotees of the current method are more concerned with the pedigree and genealogical connections of an idea, than with its own proper goodness or badness, its strength or its weakness.' The author goes on to show, from his point of view, some of the evils attendant on this method, such as, 'its tendency, if uncorrected, to make men shrink from importing anything like absolute quality into their propositions,' and 'to place individual robustness and initiative in the light of superfluities with which a world that goes by evolution can very well dispense.' 
study and contemplation-one such mode being the study of the development of such organism. But a synthesis of all our modes of study is the necessary preliminary to our obtaining the least imperfect apprehension which is possible for us of any animal or plant. We cannot grasp it in its totality and unity - in its essence-we can only comprehend it approximatively, as we approach it, intellectually, on as many different sides as we can, and as nearly as we can.

To return to the question of the vertebral or non-vertebral nature of the skull: the result of all the controversy on the subject, up to the present time, is that such vertebral nature may be affirmed in one sense and denied in another, according to the line of thought which is followed.

The whole body of every animal with a distinct skull and backbone exists at first as a rounded, almost structureless, mass of tissue, in which the first clear indication of such animal is a longitudinal furrow marking the place of the future spinal marrow and brain. Beneath this furrow a rod made up of cells (the chorda dorsalis) comes to lay the foundation of the future spinal column. From each side of the groove a fold extends upwards, the two folds being called the lamino dorsales, and these folds meeting together above, form a canal. It is within that part of the laminoe dorsales which form the spine that first the cartilages, then the bones, are developed which form the sides of the vertebral arches. Similarly, it is within that part of the lamina dorsales which form the skull that first the cartilages and then the bones are developed which form the sides of the skull arches, and thus there is an undeniable similarity between these two parts. Moreover, in subsequent development, the bones of the skull - especially in the higher animals-present a singular reminiscence of vertebræ in the three serially successive arches which they form. Certainly, if the essence of vertebræ consists in their being a series of bony rings fitted together, 
and enclosing the nervous centres along the dorsal region of the frame, then it must be asserted that, in that sense, the skull is in part composed of three bony vertebræ.

In certain fishes the transition from the spinal column to the skull is so gradual that it is easy to mistake part of that column for part of the skull. Thus, in the sturgeon, the cartilaginous representatives of true vertebræ coalesce into one mass with the cartilaginous skull; and in the Siluroid fish Bagrus the bony vertebræ next the head are greatly expanded, and join each other by the same mode of union (by suture) as do true cranial bones, and this shows how undoubted vertebræ may simulate cranial walls.

There are, however, various elements which enter into the composition of the brain-case (or skull) which do not enter into that of the spinal-marrow-case (or vertebral column), and there are differences as to development; but, after all, the existence of a remarkable secondary and induced resemblance between these skeletal parts is undeniable.

As to development, it has always been affirmed that while the spinal column is essentially, and in almost its earliest stages, a serially segmented structure, the primitive skull presents no serial segmentation. It is, indeed, true that parts which temporarily or permanently represent in cartilage the bony skull are never serially segmented; and more than this, the cartilaginous precursors of the bones on one side may be completely separated by an interspace of softer substance from their fellows of the opposite sidea single fore-and-aft segmentation in the skull thus violently contrasting with the manifold transverse segmentation of the spine. But a most interesting point has lately been noticed ${ }^{1}$ -namely, that in the young eft and the axolotl, before the base

I See the paper before referred to, Proceedings of the Zoological Society, 1874, p. 196, pl. xxxi., figs. 1 and 2.

VOL. II. 
of the future skull has become cartilaginous, an indication of transverse segmentation is to be traced in the soft tissue of that region-a proof of what oversights may be committed by relying too hastily on development as our guide. The continuous chondrification of the base of the skull before observed, had led to a denial of all fundamental transverse segmentation of that region by the opponents of the vertebral theory of the skull, while the assertors of that theory regarded such continuity as an induced and adaptive masking of a segmentation visible to the eye of the intellect, though not to that of the sense. The latter view now turns out to have been the right one, and a latent tendency, speculatively divined, has now been to a certain extent made palpably evident. How many other latent tendencies may not exist which never render themselves visible to sense? Might it not be contended that the ultimate segmentation of the bony cranium of mammals is one mode of expression, disguised and highly modified, of such latent earliest tendency to serial segmentation?

But most striking of all recent phenomena concerning the vertebral archetype, is the explicit return just made by Professor Huxley ${ }^{1}$ to the conception so long ago advocated

1 See Proceedings of the Royal Society, No. 157, p. 127. The author's determination of the homologies he seeks to establish rests entirely upon the constancy of position of the velum palati, which he has selected as his fixed point. A certain hesitation in assenting to the new view may be justified by the absence (as far as yet known) of the auditory organ in the amphioxus. If there is one thing which is constant in the vertebrata it is the auditory capsule, and the figures on the paper referred to, show it relatively largest in the youngest condition of the ammocres chosen for comparison. The distribution of the cranial nerves can hardly be said to afford decisive characters, since as there are myotomes, if nerves are supplied to them laterally from a central nervous trunk, each nerve must divide into a dorsal and a ventral branch to supply each muscular segment. Similarly, nervous supply must be sent to the front end of the body, and if the so-called eye-spot of amphioxus be an eye-spot, the circumstance that this nerve passes over it, though a striking fact, is scarcely sufficient to identify it with the ophthalmic division of the fifth nerve of fishes and higher vertebrates. 
by Professor Owen, that serial segmentation, however latent and disguised, extended primitively and fundamentally to quite the anterior end of the head. The first-named Professor now advocates the view that we have an approximation to the early form of the vertebrate skull in that very exceptional little fish the Lancelet (Amphioxus), ${ }_{1}^{1}$ in which the front end of the body is, like all the rest of it, made up of a series of similar segments, although the part representing the bodies of the vertebræ of higher animals is itself unsegmented. The general resemblance of the new concrete type of Professor Huxley to the old type, as exhibited in the wellknown plate of Professor Owen's book on the archetype of the vertebral skeleton, is striking enough.

It is none the less true that there are profound differences between the two conceptions. According to the recently put forth view, the skull of the higher vertebrates is really made up of something less than twenty segments, each of which has a morphological value equivalent to a spinal vertebra with its annexed parts. Again, the recent conception does not repose so much upon a speculative basis, but presents us with an apparently concrete type instead of an abstract ideal. And yet even the concrete Amphioxus must after all be idealised to serve as the type of vertebrate structure, since in ear-structure it is strangely defective, and, though its body is segmented as a whole, the central part of the spinal column is not segmented, but presents, like the embryos of the higher animals, a continuous chorda dorsalis.

The conception of cranial vertebræ, then, like the concep-

1 The constantly increasing number of instances of the independent origin of similar structures makes us think it far from impossible that vertebrate genetic affinity may lie at least as much in the direction of the annelid worms as in that of the ascidians, and that there are hardly yet data to determine which of the curious relationships exhibited by the Lancelet are due to genetic affinity, which to homoplasy, and which perhaps merely to degradation. 


\section{Likenesses; or, Philosophical Anatomy}

tions of serial, bilateral, and general homology, all pertain to 'Philosophical Anatomy,' and are subjective apprehensions of relations which have an objective existence in nature. Such conceptions are similar to our conceptions of 'types,' the very name of which is distasteful to so many. It is true that types, as types, are not real objective entities. But though, as types, they are ideal, they have none the less a basis in reality. The fact that they have no complete concrete being as types, is no more a reason for refusing to recognise their existence than is the non-existence objectively of species, as species, a reason for refusing to recognise the individual realisation of a species, and to make use of zoological and botanical specific names. The acceptance of the theory of Evolution forms no bar to the reception of that view which represents all organic forms as having been created according to certain fixed ideal types. The two beliefs, far from being reciprocally exclusive, can and do co-exist in perfect harmony in one and the same individual mind.

But have the conceptions of philosophical anatomy any other existence besides that subjective existence in the human mind, and that objective foundation in the natural world, neither of which can be denied? The answer to this must depend upon the philosophical system of him who answers the question, and especially on his belief in, and his mode of conceiving of, a first cause.

The teaching of what we believe to be true philosophy, is that the types shadowed forth to our intellects by material existences are copies of divine originals, and respond to prototypal ideas in God. Those who deny the existence of God, or who deny that we can know anything as to such existence, may, of course, consistently enough, deny or doubt the existence of such prototypal ideas. On the other hand, the teaching referred to has been ridiculed as if the maintainers of it must necessarily either pretend to possess some far- 
reaching intellectual power not shared by most naturalists, or else assert that the very natural phenomena were themselves sufficient to make manifest such transcendent conceptions. But, in fact, the acceptance of such prototypal ideas follows as a consequence, not upon the investigation of irrational nature considered by itself, but upon its investigation considered as a portion of one great whole, of which the human mind, endowed with intelligence and free-will, forms a part, and which is consequently to be viewed as the creation of God. Let the idea of God be once accepted, and then it becomes simply a truism. to say that the mind of the Deity contains all that exists in the human mind, and infinitely more. Thus it is that such human conceptions, gathered from nature, must, so considered, be asserted to be ideas in the divine mind also, just as every separate individual that has been, is, or shall be, is present to the same mind. Nay, more, such human conceptions can be but faint and obscure adumbrations of corresponding ideas which must exist in perfection and in fulness in the mind of God.

We have seen that even by viewing organisms from all the points of view possible to us, we can but attain to a very imperfect comprehension of such organisms. But the wider and wider generalisations of broader and better-informed minds, continually advance our power of comprehension. All then who admit that the natural world is the product of a divine mind must also admit, since such mind is infinitely above all human minds, that it possesses in perfection what the most perfectly developed human minds possess, as it were, in germ.

Thus viewed, the questions of philosophical anatomy acquire a fresh value, and it becomes plain that we owe a debt of gratitude to those who, years ago, forced questions such as these upon willing and unwilling ears. Not less plain is the justification which the most modern views afford 
278 Likenesses; or, Philosophical Anatomy

them. Platonic and Peripatetic conceptions are far indeed from having been overthrown by the rising tide of a revived Ionian philosophy - a flood of which has slightly covered part of our land, and deeply submerged Germany. Philosophical anatomy, types, divine prototypal ideas are one by one emerging and reappearing, refreshed and invigorated by the bath of Darwinian Evolutionism through which they have been made to pass. It is again becoming manifest that nature, when broadly surveyed, confirms and accords with the speculations of philosophy, though never without a certain want of minute agreement, so opening fresh vistas, which invite the intellect to further advance, and to the solution of more and more recondite problems which it is the task of philosophical anatomy perpetually to strive after, to elucidate in part, but never, in this life, exhaustively to solve. 


\section{HERMANN LOTZE AND THE MECHANICAL PHILOSOPHY.}

A NOT unimportant contribution towards the elucidation A of that great question, 'What is the most rational conception of nature possible for us ?' has been lately made accessible to English readers unfamiliar with German. We refer to a translation which has recently appeared of Hermann Lotze's great work entitled Microcosmus: an Essay concerning Man and his Relation to the World. ${ }^{1}$ The opinions of the author with respect to this question have a special interest, because he has been so long and industrious a worker in the field of scientific philosophy, because his eminence has been so widely recognised, and because he has been so zealous and able an advocate of a mechanical conception of nature.

Rudolph Hermann Lotze was born May 21, 1817, at Bautzen, in Saxony. He studied medicine and philosophy at the university of Leipsic, where he graduated in both subjects in 1838, and became a university lecturer in both the following year. He became a professor at Leipsic in 1842, which ten years afterwards he left for a professorship at Göttingen. ${ }^{2}$

The study of medicine made him feel the absolute necessity of a knowledge of physical and biological science for any one who would aspire to philosophy, and forced upon his

1 In two volumes, translated by Elizabeth Hamilton and E. E. Constance Jones. Published by T. \& T. Clark, of Edinburgh, in 1885.

${ }^{2}$ For further details see Dr. Friedrich Ueberweg's History of Plilosophy, vol. ii. 


\section{Hermann Lotze and the Mechanical Philosophy}

mind the complete untenableness of Hegelianism. At starting he appeared to be a thoroughgoing upholder of the mechanical view of nature. In his Pathology ${ }^{1}$ he sought to show that the processes observable in the living body are in no way fundamentally different from those of insensient nature, the only difference being in the arrangement of the parts upon which the physical forces act. 'Vital force,' he taught, 'is not to be understood as any distinct force, but rather as the sum of the effect of numerous partial forces acting under given conditions.' Naturally enough his writings were quoted with cordial approbation by men of the materialist school; but already in his Physiology, ${ }^{2}$ he repudiated materialistic dogmatism, and promised to enter more fully into the subject subsequently. This promise was fulfilled by the publication of the work $^{3}$ to some of the contents of which we here wish to call attention. The judgments expressed in it led materialists, who had accustomed themselves to reckon Lotze as one of themselves, to denounce him as an apostate. He has not, however, really repudiated his former teaching as to mechanism, and certainly he has in no way weakened his denunciations of vitalism. The head and front of his offence in the eyes of those who deem him a renegade, is his endeavour to show that the mechanical conception of nature, as understood by him, is not in any necessary contradiction with a spiritualistic conception of the universe. We would by no means be understood to express approval of the work generally - a work in writing which the author appears to have considered nothing human as foreign to his subject, so wide is its scope and so multifarious the matters treated of in it. With many of his views we differ toto calo; and as to others with which we agree we deprecate

${ }^{1}$ Allg. Pathologie und Therapie als Mechanische Naturvissenschaften, 1842.

${ }_{2}$ Allg. Physiologie des Körperlichen Lebens: Leipsic, 1851.

${ }^{3}$ Milcrokosmos : Ideen zur Naturgeschichte und Geschichte der Menschheit. 3 vols. Leipsic, 1856-1864. Second Edition, 1868. 


\section{Hermann Lotze and the Mechanical Plitosophy 28I}

the modes in which he advocates them. Nevertheless, as a very distinguished thinker and teacher, and one who has had no inconsiderable following, we gladly avail ourselves of the opportunity of introducing him to such readers as may not yet know him, as an occasion for saying a few supplementary words on that question which seems to us one of the most important of our own day-the question as to which of our conceptions concerning nature is nearest the truth.

Now the common-sense of mankind has always recognised fundamental distinction between living things and things devoid of life, and common-sense we should remember enshrines something more than the opinion of any one man, however distinguished, and demands respectful consideration though not slavish subjection) as an expression of the judgment of many generations of men. The conception of living reatures being permeated by a special force distinguished rom the merely physical forces as 'vital,' was invented by a chool of physiologists who were no doubt under the influence of this dictate of common-sense. But this conception, known as 'Vitalism,' has found less and less favour with scientific men, and almost all the most advanced physiologists now avour and seek mechanical explanations of vital phenomena. Such a change must be due to some good reasons. It is mpossible to suppose that leading men of science can have anged themselves in opposition to vitalism through any nere prejudice of whatever kind. There are at least three easons for the course they have pursued: (1) the exigencies f scientific progress; (2) the necessary conditions of human nental activity; and (3) the nature of all forces, whether physical' or 'vital.' Science, in the popular sense of the word, progresses by the discovery of uniformities in the coxistences and sequences of phenomena, and conceptions which relate not to phenomena, but to existences supposed to underlie phenomena, cannot be expected à priori to have 


\section{Hermann Lotze and the Mechanical Philosophy}

much influence on such scientific discovery. Experience confirms this anticipation. The progress of physiological and medical science has been in fact due not to any theory of 'vitalism' (or other conceptions not to be verified by experiment and observation), but to investigations conducted in harmony with mechanical conceptions. No wonder, then, that physiologists are inclined to favour views which have been found of such practical utility. In the next place it is a law of the mind that not even the most abstract thoughts can take place except by the help of the imagination, and nothing can be imagined by us which has not been the subject of sense-perception. But this is by no means all. The imagination is most easily affected by objects which can be distinctly seen and definitely felt, as is shown by the terms we spontaneously employ to denote various bodily and mental affections. Thus people speak of a 'sharp pain,' 'like a knife,' a 'light character,' a 'hard heart,' a 'bright disposition,' and say that ill tidings have given them 'a heavy blow.' Therefore a mechanical conception of nature, which imagines natural processes in terms of motion, must naturally and readily find acceptance amongst men, whether or not it be approved by reason on mature reflection. Lastly, the idea of a 'force' which is common to all living things, and to them only, is an idea which not only troubles the imagination but is repugnant to reason. Either such an energy is conceived of as being absolutely one with a living creature manifesting itself, in which case it must be an individual energy in each living thing, and not one common to them all, or it is conceived of as being distinct and a substance in itself-a grotesque conception, in support of which no valid reason can be adduced.

Vitalism, therefore, is in his last work, as in his first, consistently opposed by Lotze, and we agree with him in not only admitting, but in affirming, that men of science are fully 
justified in making use of a mechanical theory of nature as a practically useful working hypothesis. But after admitting and affirming this, our author goes on to also affirm that beyond the domains of merely physical science (which though nuch, is not everything) reason does demand a nonnechanical conception, namely, the conception of an immaent active principle or soul in everything which lives. This onception (which we ourselves have always maintained ${ }^{1}$ as eing a conception demanded by philosophy, as distinguished rom the sphere of merely physical science), is fully upheld y our author, and we will now confine ourselves to a few eferences to passages in his Microcosmus which support this ssertion.

Thus, as to the inadequacy of the popular conception of xternal forces without the presence of an immanent internal ctivity, he says: ${ }^{2}$ 'Forces do not attach themselves to a feless inner nature of things, but must arise out of them, nd nothing can take place between the individual elements ntil something has taken place within them.' Again, as to he inadequacy of material conceptions of organic unity, he ells us : ${ }^{3}$ 'Our ideas of the connection of organic parts are too auch modelled on that of a bundle of objects, which being adifferent to one another and totally destitute of cohesive ower, need to be tied together by a bond external to them 11. That is the meaning of the common craving to know he bond that holds together the body and the soul, or the onstituents of the body, or, lastly, the mental elements. or the connecting principle of these last, though probably onceived as higher in its nature than a material bond, is yet ot thought of as essentially different from a cord; for it

${ }^{1}$ The conception which we have maintained is that of Aristotle, namely, ce conception not of an immaterial substance distinct from the material ganism of a living animal or plant, but of an active principle of individual$m$ absolutely one with the living material organism of such animal or ant.

2 Vol. i. p. 49.

'3 Ibid., p. 58. 


\section{Hermann Lotze and the Mechanical Philosophy}

seems to be regarded as something which, while itself one and indivisible, fastens together a plurality of hitherto unrelated parts by very much the same folds and knots as a cord.'

As to the necessary unity implied by consciousness, and shown to exist by states of consciousness, he observes: ${ }^{1}$ 'This belief in the soul's unity rests not on our appearing to ourselves such a unity, but on our being able to appear to ourselves at all.' 'All the operations of a joint plurality either remain a plurality of separate operations, or become truly fused into one, only when transferred to the unity of a being as its states. Of consciousness we can say that, as the energy of an indivisible being, it does render possible the composition of the many with the one, but that the unity of consciousness never can spring solely from the mutual action of the many.' 2 'That most peculiar bond of the multitudinous: the active element that, passing from one to another, leaves both in existence, while it is aware of the kind and direction of its transition, cannot itself be inultitudinous.' 3

Some of Lotze's remarks concerning memory are very noteworthy. He reminds us ${ }^{4}$ that an act of memory 'not only recalls what has been forgotten, but at the same time brings about a consciousness of its identity with the new impression. Hence old and new must not wholly coincide but must be recognised as two different recurrences of the same idea.' He argues ${ }^{5}$ that memory is more than a faint revival of groups of past sensations, inasmuch as memory ' while it faithfully repeats the contents of previous sensations as regards their character and intensity, does not repeat the disturbance which we underwent from them '; for there is no difference, for example, between our recollections of the loudest clap of thunder and the softest musical tonc before experienced, at all comparable with the difference
1 Vol. i. p. 157.
4 Toid., p. 215.
Ibid., p. 161.
s Ilid., p. 166.
${ }^{5}$ Ibid., p. 205. 
between the two actual impressions at the time of their reception by our sense organs. The idea of pain is not necessarily pain, nor that of pleasure pleasure. After all,', 'things related logically and by general principles have a stronger material affinity than things naturally strange to one another, which only the accident of their being simultaneously perceived brought together in consciousness.'

Our popular psychologists confound the mere animal association of images with logical ratiocination, and they also confound the sort of 'expectation' to which in animals such associated images may give rise, with the syllogistic process. Lotze protests ${ }^{2}$ against this, inasmuch as though such expectations are as serviceable for the practical ends of animal life as would be true reasoning, 'nevertheless the syllogism involves a wholly different intellectual exertion from the instinctive expectation,' for therein we 'justify the combination of the expected with the perceived by the thought of a universal law in virtue of which the two cohere.' However adequately the imagination may serve the ends of merely animal life, there is yet in animals 'an utter absence of one mental operation which forms part of human thought.' ${ }^{3}$ We do not at first passively receive combinations of impressions, and later 'the amended selection of these left behind by the self-correcting movements of the psychic mechanism. Our thought, with independent action, breaks up the accidental associations of ideas, and instead of merely leaving intact those which are coherent, puts them through a process of reproduction, after which they appear in forms that at the same time contain an indication of the reason why they are combined.'

Our author makes many valuable remarks concerning language, and well depicts ${ }^{4}$ its essentially logical nature as
1 Vol. i. p. 217.
3 Ibid., p. 620.
2 Ibid., p. 235.
4 Tbid., p. 622. 
universally displayed by grammar, however imperfect and rudimentary. 'If there are everywhere ${ }^{1}$ forms for substantives, verbs, and adjectives, this shows that the mind must have developed everywhere the notions of Thing, of Becoming, or of Quality.' Lotze fully recognises ${ }^{2}$ our need of language, since though 'of course it does not impart to the mind the elements of thinking, yet it is indispensable when the mind has to combine these elements into the spacious fabric of its culture.' Nevertheless he also fully recognises that thought is wider and greater than language, and that the spoken word, the verbum oris, is a check and restriction on the nobler verbum mentale. Thus, after showing ${ }^{3}$ that the fact of our being able to make comparisons proves that we can entertain two ideas simultaneously, he adds: 'The habit of mental speech really retards the passage of thought by breaking up into a sequence what was originally simultaneous.' 'Thinking, of course, ${ }^{4}$ itself requires some time, but the constant recollection of words protracts the time by its dependence on bodily conditions from which thinking could have kept itself free.' 'Thought,' he tells us, ${ }^{5}$ ' is not so absolutely dependent on language that combinations of sounds are of necessity the medium through which it expresses its formal conception of the control of presentation.' On the contrary, ${ }^{6}$ 'language is often a hindrance to the cultivated understanding,' because it does not follow the codifications of thought ' with sufficient pliability.'

Some other prejudices and mental imperfections which favour a mechanical and materialistic view of nature are also forcibly pointed out in the work. Thus he observes ${ }^{7}$ that, 'spoiled by the successes of physical science, we too often regard maxims, unquestionably valid for the explanation of

1 Vol. i. p. 679.

4 Tbid., p. 632.

2 Ibid., pp. 634 and 637.

5 Tbid., p. 624.

3 Ibid., p. 213.

Ibid., pp. 195, 275, and 276.

6 Tbid., p. 680. 
physical processes, as universal and necessary truths.' The ample satisfaction afforded to our imagination by the entertaining variety of successions of images too often makes us forget how wholly unsatisfying they are to our reason.

Our extracts have already shown that Lotze speaks freely of the existence of a 'soul' in living things. Indeed he boldly maintains that view, and regards the indisposition of many to admit it as being due to those prejudices to which we have just adverted. Thus he observes: ${ }^{1}$ 'In granting that the essence of the soul is unknown, we do so only in a sense that includes the impossibility of saying what would be the essence of anything in the entire absence of the conditions that are the exciting occasions of its manifestations. Just as inpossible as to tell how things look in the dark, is it to know what the soul is before it enters on any of the situations in which alone its life unfolds.' To this 'soul ' he also unhesitatingly attributes pre-eminence, ${ }^{2}$ saying the 'rejection of a false conception of the mode in which the soul takes part in the construction of the body need not prevent us from holding such participation to be in itself great and important. The soul by reason of its more significant nature must always have a place of vantage.' He teaches $^{3}$ that the soul of every animal is that immanent principle of individuation, the existence of which we have again and again asserted, saying that the animal's soul unquestionably concentrates the multitude of impressions ' in a unity,' feels pain and pleasure in respect of them, and uses them as starting-points for future action. What is much more important, he denies ${ }^{4}$ that the human soul has any material 'organ.' 'The perfection of mental life is indeed (which has never been denied) connected by myriad roots with the soil of its bodily existence; but the soul does not, besides the general nutrition which it affords; send upwards
${ }^{1}$ Vol. i. p. 190.
2 Ibid., p. 288.
${ }^{3}$ Ibid., p. 633.
${ }^{4}$ Ibid., p. 323. 
a special organ of which the plant (i.e. the soul) must make use if it is to flourish.' 'When organs of understanding or of reason, instruments of thinking and judging, are spoken of, we confess that we have no idea either what end such theories can serve, or what advantage there could be for the higher intellectual life in all this apparatus of instruments.' 'If every several ${ }^{1}$ atom of the central mass is capable of retaining without confusion numberless impressions, why should the soul alone, like the atom of a simple being, be incapable of doing so? Why should it alone not possess the faculty of memory and recollection in itself without the aid of a corporeal organ, when we have to concede this faculty directly and without the mediation of a new instrument to every part of the assumed organ? Nay, we must in fact make the contrary assertion that the retention and reproduction of impressions is possible, not to a number of co-operant cerebral particles, but exclusively to the soul's undivided unity.'

Thus this noted upholder of the mechanical view of nature proves by his latest work that he is none the less fundamentally a supporter of all that to which mechanism is generally regarded as being the most opposed. We will conclude with one more citation, which we think forcibly points out the essential irrationality of Hume's modern followers' first article of faith. That article of faith affirms that we have not and cannot have supreme certainty of our own continued personal existence. As to this Lotze remarks: 'Among all the errors of the human mind it has always seemed to me the strangest that it could come to doubt its own existence, of which alone it has direct experience, or to take it at second hand as the product of an external nature which we know only indirectly, only by means of the knowledge of the very mind to which we would fain deny existence.'

1 Vol. i. p. 327. 


\section{A LIMIT TO EVOLUTION.}

THE limit to Evolution here referred to, is the limit which some persons assert and some deny to exist between man and the lower animals. Granting, if only for argument's sake, the truth of Evolution, can man have been evolved from the lower animals, or must his origin have been due to some different action from that by which animals arose? The great difference between man and the lower animals consists not in his body, but in his mind. In order, therefore, to examine this question, we must begin by looking a little carefully into our own minds, and by examining our own acts and mental nature.

Now we all know that we perceive ourselves, other people, and a variety of objects about us. Also that we can recollect them and reason about them and express our opinions by words or signs. This is what every sane man can do in every country in the world. But besides these intellectual endowments, we have certain other powers and capacities which we ought very carefully to note.

In the first place, we have all a power of feeling (we possess sensitivity), and we have many different kinds of feelings, apart from our intellect. Thus we all have appetites and desires, which, however they may be controlled by reason, are in no way due to reason any more than are feelings of pleasure and pain, with which new-born babes and even idiots are endowed. We do not need intellect in

VOL. II. 
order to feel hungry, or that we may make a hearty meal. We all of us have also the power of feeling special sensations, as of some colour or musical tone, or of bitterness or warmth; and feelings which have been experienced may again be reproduced in the imagination, wherein images arise which are faint reproductions of before-felt sensations.

We may next note our wonderful power of memory, not that intellectual faculty which we exercise in seeking to recall the past to mind, or by which the past flashes forth uncalled into consciousness, but that lower kind of memory, which we may distinguish as sensuous memory. This it is which enables us to perform a multitude of actions not only without the very intervention of our conscious intelligence, but so that the intervention of that intelligence may actually impair its action. We have familiar examples of this kind of memory in such acts as walking, running upstairs, playing the piano, etc. Almost every one who plays by heart knows that, if he happens to stumble in playing a familiar melody, his best plan is to turn away his mind from what he is doing and try to play it automatically. In other words, the melody is recalled by trusting entirely to that retentive sensuous memory which has become, as it were, imbedded in the nerves and muscles - the memory of the imagination.

We have, again (and this it is very important to note), a power of associating together sensations and imaginations in groups, and in groups of groups: so that when one or more of the thus associated feelings is freshly experienced, all the other feelings which have become associated therewith tend to be aroused also. Examples of this habit abound. The sound of a dinner-bell, the sight of an expanded umbrella, may instantly arouse in our minds images of food or of rain. It is not only that we intellectually know that the dinner-bell calls us to dinner, and that the umbrella is probably ex- 
panded on account of rain; but these associated images may arise before such thoughts, and images of the kind will often persist in spite of our efforts to expel them. In hearing, after an interval of many years, some melody of early days, very vivid images may be aroused. The old man may become in imagination a youth once more, and seem to feel his feeble limbs again treading the rhythmical measures of the waltz and his arm sustaining the pressure of a form dear to his memory. Thus we come to have those complex associations of pleasurable or painful feelings which we call senuous emotions, some of which may be occasionally aroused in us apart from the exercise of our reason.

We have, moreover, not only these pleasurable and painful feelings. We also possess an innate spontaneous tendency to rest in, or to pursue and plunge deeper into, whatever we find to be pleasurable, and also to avoid whatever is painful.

Again, when we act, we have a certain vague feeling of our self-activity. Our intellectual consciousness of what we may be doing is not here referred to, but that feeling which accompanies our actions when our attention is quite turned away from them-as when we walk unconsciously along, immersed in thought. It is plain that we do have this feeling, for if our progress is accelerated by something external - as a gust of wind-we immediately have a different and contrasted feeling. We have, indeed, a feeling of our passivity as well as of our activity; a power of feeling (apart from the intellect), the violent action upon us of anything external, and therefore a power of feeling (as well as of intellectual perceiving) a difference between our activity and our passivity - i.e. a feeling resulting from that difference.

If we draw a chain across our hand, we have feelings which correspond with the succession of its parts as they pass, and a feeling corresponding with the termination of 
that succession when the motion has come to an end. It is the same in hearing a series of sounds and seeing a series of objects in a line. In each case we have feelings corresponding with the succession of the things felt, and in each case the feelings are themselves successive. In so far, then, as there is a physical resemblance between series of things felt, there is a resemblance between the feelings they induce. There is, indeed, no feeling of succession itself. 'Succession' is only apprehended by our intellect. But, nevertheless, there is a distinct set of feelings which are severally connected with different orders of succeeding things. Just in the same way, in exploring any solid object with our eyes and hands, we have the intellectual perception of its three dimensions "of length, breadth, and thickness; but we also have a number of feelings of touch, of pressure, of movements of arms and fingers, etc., and thus we come to have a group or plexus of feelings corresponding with the extension. of the object felt, together with feelings corresponding with its limits-that is, with the felt terminations of its extension. Thus, also, we come to have certain plexuses or groups of feelings corresponding with the shapes of bodies; and we also get feelings corresponding with the sizes of bodies, according as they force us to extend our arms or fingers more or less widely to embrace them, or to move our head and eyes more or less extensively to survey them. Similarly, by the singleness of impressions, or by their multitude (as in a sharp hailstorm), we come to have feelings related to the unity or multiplicity, and others corresponding with the motion and cessation of motion (or rest) of the bodies which affect our senses.

Again, we experience a certain feeling of shock when, upon the occurrence of some sensations, other sensations different from those which association has connected with the former come unexpectedly upon us. Let us suppose 
that an orange has been so artfully imitated as not only to look like, but also to feel like an orange. Being deceived to such an extent, when we cut it open and find its interior very different from what we expected, we have, of course, our intellectual perception of the fact, but we also have, as I have said, a certain feeling of shock. Similarly, if the nature of any object seen by us is doubtful, we may have a feeling accompanying suspended action; and if we find out that it is in truth what we anticipated it to be, we may have, at the instant of finding this out, another different feeling of smooth und easy transition. These feelings we may distinguish as feelings induced by various congruities and incongruities between (1) sensations, and (2) feelings, which have become associated with them.

Thus it comes about that by the association of sensations, imaginations, feelings of pleasure and pain, feelings of activity and passivity, and groups of feelings corresponding with the succession, extension, figure, size, unity, multiplicity, motion, and rest of bodies, groups of feelings of the most varied kinds come to be formed, which groups of feelings correspond with a multitude of external objects which have given rise to them. These groups of feelings underlie and accompany our intellectual perceptions of material things (as self-observation shows us), and therefore these groups of feelings may not improperly be termed 'sense-perceptions.'

The consideration of this power and habit which we have of associating feelings together leads us on to yet another consequence worthy of note. When a group of feelings has become intimately associated with certain other sensations, then upon the occurrence of those other sensations an inagination of the group of feelings previously associated therewith spontaneously arises in the mind, and we have erpectant feelings of their proximate actual recurrence. Thus the sensation of a vivid flash of lightning has come by 
associating to lead to an expectant feeling of the thunder-clap to follow, and the sight of what looks like an orange leads in a thirsty man to an expectant feeling of sweet-juicinessquite apart from his intellectual perception of the properties of an orange or of the relation between lightning and thunder. This arousing of expectant feelings has a certain analogy with reasoning or inference, although altogether different from it essentially. We may then distinguish this kind of feeling as 'sensuous inference.'

Another important fact to note is that our feelings, and especially our emotions, may be expressed by external signs, which are so far from being rational and intentional, that we may be unaware of them, or, if aware of them, unable to suppress them. Thus the emotion of terror shows itself by tremblings of lip and limb, a dropping of the jaw, suppressed breathing, a deadly pallor of the face, and staring eyes. With the emotion of anger, the eyes glare, the hands are often clenched and raised, and the lips compressed or possibly distorted in a fierce grin. Such signs and accompanying cries produce sympathetic effects in the beholders, and thus we have an emotional language, expressing merely our feelings, in addition to that power of speech by which we communicate our ideas. Moreover, our emotions may thus be so communicated as to give rise, by sympathy, to similar emotions. in others, and this, again, is closely connected with a tendency to imitation we all possess, as to which a few remarks will be made a little further on.

Let us now glance at certain sets of bodily motions which correspond with different feelings. How wonderful, when we come to go into it, is the trivial act of a lad throwing a stone at a mark! What must be the amount of correct coordination between a multiplicity of parts and their actions to produce the result! The lad's mind has little to do with it beyond his one impulse to hit the mark. He knows 
nothing of anatomy, but simply sets going the wonderful mechanism of his body, and this works out the result for him. In the first place the various parts of his eyes must be adjusted to see the mark distinctly. Then his body must be held in a certain position, and for this a multitude of nervous and muscular co-ordinations are necessary. The stone must be grasped with a certain strength, the arm thrown back to the due extent, and its muscles contracted, in co-ordination with the organ of sight, and with just that degree of vigour, as his fingers are relaxed, which shall carry the stone as desired. Different feelings accompany these actions-feelings of activity, passivity, touch, tension, etc.and these feelings guide the action of his body as if it were a sort of automatic sensitive machine.

Thus we have, apart from the action of the intellect, a power of so regulating our various bodily movements as to produce an harmonious co-ordination, in which a number of subordinate movements are co-ordinated to produce a more general movement in obedience to sensuous impulses. That these complex and orderly combinations may take place without intellectual action and from sensuous impulses only, is plain from the fact that many idiots and sleep-walkers perform them. Even with respect to ourselves, we may set our bodily organism going in a certain direction, and then give up the mind entirely to other matters, so that we walk on, 'lost in thought,' till we are startled at finding we have reached_or it may be overshot_our destination, without having once thought about our journey on the road. But the remarkable power we have of co-ordinating our motions, in response to associated sensations, is excellently shown in such a thing as playing the piano by heart. Here the actions duly follow in orderly series in connection with felt touches of the keys and heard sound of the notes. Let a key stick, or a wire become dumb, and the automatic 
action ceases immediately, and the intellectual attention is aroused.

The result of all the foregoing powers of feeling and coordinated movements is, that we have an automatic power of uniting our various pleasurable tendencies into now one and now another dominant impulse, and of further co-ordinating our movements so as to unite them in one general movement directed to gratify such dominant impulse. As to our tendency to imitation, it is notorious that the sight of a yawn induces yawning. Such spontaneous imitation is often carried much further, notably by some idiots. Nor is it surprising it should be so, when we reflect that the sight of a motion performed by others slightly stimulates in us those very nerves by which such motions have been brought about in them. Let this nervous stimulation be much augmented, and actual movement on the part of the spectator may necessarily follow.

Lastly, we have, through the action of associated feelings and co-ordinated motions, the power unconsciously and automatically to employ what are practically 'means to effect some end.' Thus a sleep-walker will open a drawer to take out of it some desired object, or will turn a key to unlock a door, and so obtain entrance into some locality sought after. This seems strange, but it can be quite well accounted for by an action of the nervous system essentially similar to that which occurs through the association of feelings, and in imitation. For the senses have present to them groups of sensations, such as those from the walls and furniture of the room the sleep-walker is traversing on his way to the desired locality the door of which is locked. The sensations so felt arouse the imagination of the inside of the desired locality; this arouses the nervous channels habitually stimulated in overcoming the intervening obstruction; the hand automatically seeks the key, the stimulus of its touch stimulates the muscles of the arm, the key is turned and the 
door opened. Very complex motions of the kind are sometimes performed in order to complete a harmony which the imagination craves. It craves for fresh completing sensations, and is thus led to perform appropriate movements, when certain initial sensations, after which the completing sensations have (in past experience) habitually followed, have been afresh excited. This, then, is the practical imagination of means to effect a desired end, without any intellectual apprehension of either end or means. Such are some of the many and wonderful powers of feeling with which human nature is endowed-powers apart from the intellect, for they may be exhibited by persons who are permanently devoid of intellect or in whom it is temporarily dormant.

Now let us turn to the higher and intellectual powers of our nature, and examine two or three of them. As before said, we all know that we have perceptions of things about us. But what is a perception?

We perceive a handkerchief! How do we perceive it? Through a number of impressions which it makes on our senses-such as the feeling of a white colour, of a certain soltness and pliability, a certain smoothness, and other feelings such as those described a little time ago as culminating in 'sense-perception.' But all these feelings are only the means, not the object of perception. It is through and by them that we directly apprehend the object, the handkerchief itself, with its various properties.

So with all other external objects, the feelings they occasion in us, however intimately grouped, are but the signs of the object they make known. We can, however, attend to the signs themselves if we will. In looking at a house, for example, we can, if we please, observe the shape of the image made by it on our field of vision, and draw out its perspective lines. But when we look at a house ordinarily, we do not perceive them but $i t$. 
In looking at a revolving cube, we only see portions of it at a time, and its square faces, seen in perspective, do not look square. Nevertheless, through these imperfect sensible signs, we have an adequate perception of the whole cube as it is in itself. Observe, also, that the very revolution of the cube (and the consequent changing of our sensations) does not change our intellectual perception, which remains the same throughout. Perception, then, is a natural and spontaneous interpretation of sensible sights by a special power of our intelligence-a power which can be much improved by practice.

But into what does this natural power interpret the signs given through our sense-organs by external things? Into the apprehension of some object which, as standing, as it were opposite to our mind, we call 'objective'; while all the feelings that object produces in us, as being affections of us -of the subject who feels-we call 'subjective.' In every perception, then, we perceive an object of some kind. It may be we know it as 'a horse,' or if not that, as a 'quadruped,' or as ' a living creature' only, or merely as 'a solid body,' and if we cannot be sure even of that, then at least we perceive it as something.

'Something!' What a wonderful idea is enshrined in that most familiar expression something! It is the idea of 'existence,' the idea of 'being.' It is an idea which, however its latent implications may be unfolded, is itself inexplicable, for no one can even ask what it $i s$, without showing by his very question that he both possesses and understands it. The idea of being, or existence, is one which is applicable to everything which can be conceived of by the mind. Those other (much more restricted) apprehensions or ideas of objects just mentioned-' solid body,' ' living creature,' ' horse,' etc.-are also each applicable to a greater or less number of things. Thus even the idea 'horse,' is applicable to a multi- 
tude of individuals of the same kind-to all horses. At the same time, the idea or conception considered in itself is ONE. It is a single notion-not indeed a notion of any individual subsisting thing, but of a kind or class of things, real or possible, to each one of which the notion is applicable. It is therefore a general or universal idea.

The contrast, the difference of kind, which exists between this intellectual conception and the various forms of feeling, is very great.

Feelings, whether single or in groups of groups, are all modifications of the sentience of the being who is the subject of them. They are impressions made on our sensitivity by individual things, or faint revivals of plexuses of such impressions antecedently made. They are therefore essentially individual and subjective, while our intellectual perceptions are essentially universal and, as they always refer to objects, objective. ${ }^{1}$ In all our automatic actions, there is no reference of objects to their classes. Things affect our organs of sense and so excite appropriate corresponding movements, and similar causes excite similar effects; but sense-perception does not apprehend them as of this or that kind, while such apprehension is of the essence of the act of intellectual perception.

The profound difference between (1) an idea, and (2) a feeling or group of feelings, is particularly conspicuous with respect to our idea of 'being' or 'existence.' It is, as before said, applicable to everything; and is so fundamental that, without having it, nothing can be apprehended or understood.

1 As Mr. Lewes has well said (Problems of Life and Mind, 3rd series, p. 497): "No aggregations of mathematical lines can make a mathematical surface, for lines are without breadth. No aggregation of images will make an idea, for images are particular, and of concrete objects, whereas ideas are general, and abstracted from the concrete by a special operation. It is true we cannot imagine a line without breadth, nor a general object without particular qualities, but we can and do think these, and this mode of thinking is Ideation or Conception.' 
Yet no sensation or group of images, however complex, could give a feeling of being; because, though there are special groups of feelings corresponding with our self-activity, and special groups of feelings corresponding with our passivity, there neither is nor can be any kind of feeling embracing all feelings ; and yet, if there were any possible feeling of 'being,' it must necessarily be of this universal character, and, nevertheless, a distinguishable feeling of some sort. But though we have no feeling of being, the idea of being lies at the very root of all our conceptions, and exists at the beginning of our intellectual life. This supreme notion arises spontaneously in the mind of the little child who lisps, "What is that thing, mother ?' and may often be clearly perceived to have arisen long before any word whatever can be uttered.

It is, nevertheless, quite true that we cannot have any of the ideas or notions which perception gives us, without first having sense-impressions to act as their basis and support. This result of our bodily structure is a simple matter of observation. Our minds are first of all aroused to activity by the action of surrounding things on our senses, and afterwards by the play of our imagination; and throughout life some play of the imagination accompanies and supports all our intellectual action.

In every perception, then, we may distinguish two distinct elements, one sensuous, the other intellectual. (1) The sensuous element consists of the feelings produced in us by the action of any object on our sensitivity, and it may be called the subjective element; (2) The other is the apprehension of the object as it exists, and it is the intellectual or objective element. This latter element is twofold: on the one hand it apprehends what kind of thing the object may be, its 'whatness,' so to speak; and on the other, it apprehends the existence (or subsistence) of the thing itself.

Perception, then, is the apprehension of the subsistence of 
a thing the nature of which is revealed to us through the feelings we experience in connection with it, and is an implicit act of judgment that the thing perceived is of some definite kind. From this we may rapidly pass to an explicit and formal deliberate judgment that such is really the case, and the examination of this second act will serve to bring out yet more plainly the difference of being which exists between 'feelings ' and 'ideas.'

Every object which we perceive, possesses a number of different qualities-shape, size, colour, hardness, etc.-and acts on our sensitivity accordingly. Qur attention may be directed to various qualities according to the different circumstances of each case, and then these qualities may be distinctly and expressly recognised as really being qualities of the object observed. The power by which we thus ideally separate qualities is the power of abstraction, and by it our mind isolates (in order to apprehend them distinctly) the various qualities and conditions which, in truth, exist, intimately united in the concrete object perceived. Let us take as an example the explicit judgment, "That object is an oaktree.' In making this judgment, we abstract, mentally, certain qualities, such as 'solidity,' 'vitality,' 'branchingshape,' 'vegetable nature,' etc., which ideas are therefore 'abstract ideas,' because thus abstracted. To see this clearly, let us consider for a moment the quality 'branching-shape' of the oak, as it exists in reality, and as it exists as an 'abstract idea.' In reality, it exists as one of the qualities of that one particular, individual oak, a quality absolutely and indissolubly united with it, and not existing at all except in that one oak-tree. As an abstract idea, it is a general conception-an idea applicable not only to all oak-trees, but to all branching things.

One very important primary and fundamental abstraction, already glanced at, should be distinctly noted. In 
order to say, 'That object is an oak-tree,' we must have the conception, as before said, of the kind of thing the object is, 'what' it is, or the idea of its 'whatness.' At the same time, our intention is not to affirm that a kind exists, but that a real concrete thing exists of a certain kind. We must therefore have mentally separated the 'idea' of the oak-tree, from our perception of the concrete existence, or 'subsistence,' of that really existing material thing.

These processes of mental abstraction are a necessity of our nature. As soon as we begin to reason, as soon as we ask ourselves what anything is and try to have any clear and distinct notion about it, we are compelled thus to, mentally or ideally, separate its qualities by abstraction. Now comes the final act which completes the explicit judgment. This act consists in putting ideally together what has just been ideally separated. For during the very process of abstraction we have not ceased to feel the object acting on our sensitivity - or we have remembered it-and our mind has never lost sight of the real unity - the concrete identity - of the oaktree, the qualities of which have been mentally, or ideally, abstracted. It is the expression of this perception of unity, together with abstraction, which constitutes the explicit judgment. For this explicit judgment, then, three mental acts are necessary:-(1) The apprehension, through a union or 'synthesis' of feelings (produced by the qualities of an object) of a certain kind of thing; (2) a mental analysis or separation of its qualities by abstraction; and (3) a mental synthesis again of the qualities previously abstracted.

Judgments are amongst the elementary acts of the human intelligence which cannot exist without them. The human intellect, therefore, is an intelligence which necessarily proceeds by an alternate process of union or 'synthesis,' and of separation or 'analysis.' It is an active principle which operates by alternately uniting and dividing. This 
complicated process is necessary because our mental food, like our bodily food, needs to be digested in order that it may be assimilated. In this process it is abstraction which plays the part of a mental gastric juice. A moment's consideration will suffice to show us how much clearer and more luminous are the qualities of any object when they are thus abstracted and distinctly regarded, than when apprehended confusedly and indistinctly in one lump, in our first act of perception.

This complex process, which it has taken so long to describe, is performed by our mind with exceeding rapidity. It is all done while we say, 'That is an oak:' That we should do all this without being aware of it, may seem strange. Yet it need not do so. How many persons say B, without thinking, or even knowing, that in order to utter it they must, if the mouth be open, first close and then reopen the lips!

In perception, we form a notion from a number of elements. In abstraction, we resolve a notion into a number of elements. It might, then, be supposed that the elements into which any notion is resolved by abstraction are those very same elements through which that notion had previously been gained. In other words, it might be supposed that abstraction was some sort of return towards the condition existing the moment before perception. But to suppose this would be a great mistake. The elements which minister to perception are sensible elements-feelings of various kinds resulting from the sensible qualities of the objects perceived. In their ministering state, before they are apprehended by the intellect, they are mere feelings or affections of our sensitivity, and therefore (as we have seen) essentially individual and subjective. The elements which are separated by abstraction are ideal elements, and therefore essentially universal and objective.

Now that we have thus examined what we do in forming 
explicit judgments, we are in a position to appreciate more fully than before the fundamental difference which exists between feelings and ideas. We may now see that feelings are not only particular and subjective, but are also impressions made on our sensitivity by really subsisting and individual, that is, concrete, properties of bodies; while ideas are abstract as well as universal. Again, the same feelings are, under similar conditions, excited by the same sense impressions; while not only may the same idea be called forth by very different sets of sense impressions, but also the same set of sense impressions may call forth very different ideas. Thus the abstract idea 'Motion' may be apprehended through-(1) the passage of the image of an object over the retina; (2) the feeling of something slipping over our skin; (3) the feelings of tension, etc., produced by the muscles of our eye-balls in following an object with our eyes; (4) the sensations of touch given by a moving object while we grasp it, etc. Yet the resulting idea-'Motion'-is one and the same, however differently it may have been acquired. Again, the sight of a photograph of the Queen may give rise to very different ideas; for example-(1) to that of Her Majesty herself; (2) to that of 'royal rank'; (3) to that of 'womanhood'; (4) to that of 'humanity'; (5) to that of 'resemblance'; (6) to that of 'light and shade'; (7) to that of the sun's actinic power; (8) to that of 'chemical process'; or (9) to that of 'the substance paper,' etc., till we come at last to the idea of 'being' or 'existence.' Again, feelings can never be reflective. They can never reflect on feelings. We may also have, as has been pointed out, feelings of selfactivity, but not of any one feeling being of the kind it is. It is quite otherwise with our ideas; not only may an ideal abstract quality be made a direct object of thought, and be, as it were, held up opposite the mind for examination; but the idea itself may be perceived and recognised as being 


\section{A Limit to Evolution.}

whatever sort of idea it may happen to be. Moreover, the very intensity of the action of sensation (as with a very dazzling light or deafening sound) may make sense-perception impossible; but no amount of intensity of action of perception, no amount of vividness in ideas will mar intellectul perception.

No efforts of imagination can ever exceed sensuous experience, but it is quite otherwise with ideas. We can not only conceive, but we know perfectly well, both our power and our act of sight. Yet that act itself was never seen and cannot be imagined.

Feelings become associated according to their order of experience or contiguity. But ideas may become associated together according to the rational relations-the logical dependence of one upon another.

Different objects affect our feelings in different ways, so that we have groups of feelings corresponding with different classes of objects. But we have no feelings of kinds or classes, as such. On the other hand, ideas of kinds or classes, as such, are amongst our elementary intellectual acts

The significance of our idea of 'being' has already been pointed out, but ideas have also essential relations to 'unity' and 'truth'; while it is almost unnecessary to say no such relations exist as regards feelings.

As to unity, it is evident that in our typical judgment 'that is an oak,' our idea 'oak' refers to one kind o existence. A number of pieces of wood, iron, and canvas, looking like an oak, but not a unity, would not respond to our idea. As to truth, if what we take to be an oak were but an optical illusion produced by cleverly arranged glasses, that would not respond to our idea, nor would our judgment be what we thus evidently imply it to be-namely, true.

Such, then, is the fundamental difference of kind between feelings and ideas-between our lower and our higher facul-

VOL. II. 
ties. This distinction, which is really one of the most important in the whole study of mind and of man, is almost always entirely passed over and ignored. Yet it serves to make plain the existence of that limit to evolution which exists between man and the lower animals, and to show the 'how' and the 'why' this limit is a limit.

There is one plain and obvious difference between man and all brutes. Men speak, but animals are dumb. ${ }^{1}$

Some readers, however, may be inclined to reply that there are such beings as dumb men, and that many animals are eloquent with a language of their own. The songs and calls of birds have meanings which are practically understood by their fellows. Dogs will make certain facts known by their voice, as pointers and setters by their gestures will make known other facts; while parrots and jackdaws will learn actually to speak whole sentences!

All this is very true, but it is nothing to the point. As to mutes, the fact that some structural defect hinders one individual from speaking no more proves that man is not essentially a speaking animal than does the fact that another individual cannot speak because he is gagged! Moreover, most mutes possess a truly intellectual language of gestures. As to animals, no reasonable man can deny the expressiveness of their language, but it is nevertheless fundamentally different in kind from human language. To see this clearly, it is necessary accurately to understand what we do when we speak. Let us suppose a man and a brute to be standing under an oak-tree which begins to fall. The falling tree will produce similar effects upon the senses of both man and brute. Both will instinctively fly from the danger. Both may cry out from alarm, and both, by their cries and gestures, may give rise to similar feelings of alarm in other men and brutes. Such language, whether vocal or of gesture,

${ }^{1}$ See ante, pp. 182-185. 
is that emotional language which has been already adverted to as being possessed by us men as one of our lower and unintellectual powers; and this power is fully possessed by animals also. The man, however, may do what the brute cannot do. He may emit the vocal sounds: "That oak is falling:'

What is the nature of these sounds? The words are the embodiment and expression, not of feelings of any kind, but of three universal abstract ideas :-

(1) The word oak is, of course, a conventional sign for the idea 'oak,' and is a universal abstract term applicable, over and above the particular oak which is falling, to every other actual or possible oak. It denotes no single subsisting thing, but a kind or whole class of things.

(2) The word is denotes the most wonderful and important of all abstract ideas - the idea of 'existence ' or 'being.' It is an idea which we must have in order to perform any intellectual act. It is an idea which, though not itself at first adverted to, makes all other ideas intelligible to us, as light, though itself unseen, renders everything else visible to us.

(3) The word falling is a term denoting another abstraction - an abstract 'quality' or 'state.' This idea is evidently of very wide application - namely to everything, whatever it may be, which may fall. Yet the idea itself is one single idea.

Thus all human language (apart from mere emotional manifestations) necessarily implies, and gives expression to, a number of abstract ideas. It is impossible for any savage to speak the simplest sentence without having first formed for himself abstract ideas. Abstraction, then, is as universal as language. All our words, except proper nouns, pronouns, and certain determinating adjectives and participles, express abstract ideas. Universal abstract terms are made use of 
spontaneously by children as soon as they begin to speak, and 'quack-quack' and 'gee-gee' are just as good abstract universal terms as are 'duck' and 'horse.' Children begin by giving terms very wide meanings which they subsequently learn to restrict. This faculty of abstraction must, then, be possessed by every one who speaks, but it is also possessed by human beings who do not speak.

The difference between human rational language and the merely emotional language of animals and of men, does not depend upon the fact of Articulation. It consists in the appropriation or the non-appropriation of sounds and gestures to denote abstract ideas. Parrots articulate, but do not thereby express 'ideas.' Mutes do not articulate, but by their gestures they do express 'ideas.'

At an institution for the dumb in Edinburgh, the Lord's Prayer is acted by mutes in an elaborate manner. The idea 'Father' is expressed in an action indicating 'old man.' The idea 'name,' by touching the forehead and indicating spelling on the fingers. The idea 'done' by the hands working. The conception 'on earth as it is in heaven,' by two signs, for Heaven and Earth, and by putting the forefingers side by side to express 'equality', and so on. But the satisfactory nature to mutes of their gesture-language is shown by the protests in the newspapers recently made by some of them in its favour, and against the system of teaching them to utter articulate words. The great expressiveness of such gesture-language is also shown by the frequent performances of whole plays by gesture, without the utterance of a single word, as in various ballets. It is thus abundantly evident that rational conceptions-'abstract ideas'-can exist without spoken words. Language, therefore, is the consequence of thought, and abstract ideas are indispensable preliminaries of language. We see this in our common experience. When, in the cultivation of any science or art, newly observed facts 


\section{$A$ Limit to Evolution}

or newly devised processes give rise to new conceptions, new terms are invented to give expression to such conceptions. Thus new words arise as a consequence and not as an antecedent of such intellectual action. Nevertheless, these intellectual actions show themselves by bodily signs of sound or gesture, and even our silent thoughts are carried on by the aid of such imagined bodily signs, without which we could not continue to think. Human intelligence seems quite unable to grow or even to endure without some embodimentwithout corporeal expressions of some kind. Thus language is the means as well as the consequence of thought. The mental and bodily sides of language are so intimately united that, though the mental is anterior, it at once seeks, as it were, to incarnate itself (and under normal conditions does incarnate itself) in corporeal expression. But thought is deeper, wider reaching, and more perfect than are its bodily signs, and it is owing to this, and to the fact that thought is anterior, that we owe the growth and development of language.

By saying, then, that men speak while brutes are dumb, we mean that men are distinguished by the fact that they signify, either by words or gestures, universal, objective, abstract ideas, which are poles asunder from all powers and forms of feeling. Sense-perceptions, whether of men or animals, are groups of associated feelings; but ideas are apprehensions of objective qualities grouped round an objective unity about which various judgments may be affirmed. The former are but reinstatements of sense. The latter are unities abstracted from sense. They thus belong to utterly different categories, and a nature which has this power of abstraction is separated from any nature which has not that power, by a gulf which is an impassable limit to evolution, because feeling and intellect are both thus different in nature, and progress and develop along different and more or less diverging roads. 
But again, some readers may feel tempted to exclaim that certain animals are highly intelligent, and that very many animals know their homes, their friends, and their enemies; that, therefore, animals ' know' many things which we know, and that though they have not the use of 'words,' yet nevertheless they must have 'ideas.'

Now we should be sorry to deny the admirable and loveable endowments of the animal world. A man must have a very defective nature who does not love his faithful brute companions. But we ought not to allow affection, any more than hatred, to blind us and so mislead our judgment, and in considering the higher faculties of such creatures as dogs and monkeys, there are four rules which should ever be borne carefully in mind. These are :-

(1) To guard against the misleading tendency of our emotions with regard to pet animals. Their owners are constantly tempted to read into the actions of such animals meanings for which there is no real evidence, and to mistake imperfect influences, due to partiality, for real observations.

(2) To guard against our besetting tendency to judge everything by our own standard, and without reason to imagine the existence of human qualities in things which are not human. This is that error of undue anthropomorphism against which the opponents of all religion so often warn us.

(3) Not to suppose that unknown causes are acting, when known causes are sufficient to account for all the facts observed. This is that old well-known rule, called Occam's razor: Entia non sunt multiplicanda proter necessitatem.

(4) To bear in mind that if any cause, did it exist, would inevitably produce certain effects, we must not suppose the existence of that cause, when such effects are not to be discovered.

Now, of course, animals have 'intelligence,' 'understanding,' and 'knowledge' in the loose sense in which those terms 
are popularly used. In a sense, they have 'memories,' ' anticipations,' ' inferences,' a certain 'power of language,' etc. In a way, they ' recognise' classes of objects, seek, follow up, and rest in the pleasurable, and avoid the painful, and they also, in a sense, 'take means to attain desired ends.' What is the true nature of all these powers?

Of course we cannot while remaining human beings perfectly and fully appreciate what the mental state of an animal may be. But we can go a long way towards so doing because we are animals ourselves, and have animal as well as rational faculties. Men and the higher animals have similar sense-organs and similar feelings, imaginations, and emotions. Evidently also a similar power exists in both, of associating these feelings in groups and groups of groups, and of coordinating actions in response to such feelings. ${ }^{1}$

Now we do not for a moment hesitate to affirm that there is no known action of any animal which cannot be fully accounted for by the agency of those lower and merely sensitive powers-including the co-ordinated actions by which the pleasurable is adhered to and the painful avoided-which we know may act in animals without the co-operation of intellect, because they do so act in ourselves.

True 'intelligence,' therefore, is not (according to our third rule) to be asserted of animals, because their actions can be explained without it-can be explained by that mere sensitivity which physiology shows us they possess and which we possess.

1 The late Professor Green has observed as follows: 'We must remember that there is no reason to suppose, because the burnt dog shuns the fire, that he perceives any relation between it and the pain of being burnt. A sequence of one feeling upon another is not a consciousness of relation between them, much less of relation between facts which they represent. The dog's conduct may be accounted for by the simple sequence of an imagination of pain upon a visual sensation, resembling ones which actual pain has previously followed. . . . Till dogs can talk, what data have we on which to found another explanation?' 
But our fourth rule absolutely compels us to deny them intellectual faculties; for had they the higher mental powers they would very soon make us unmistakably aware that such was the case. To do this they need not speak, they need merely use a significant gesture-language, like that of the mutes reciting the Lord's Prayer, or like that which is used in ballets. The absence of all such unequivocal signs eloquently proclaims their essentially unintellectual nature. If animals really had ideas, those ideas would be sure to clothe themselves in a language at least of gesture. Bodily signs are necessary for the continued mental activity of even the highest human minds, and they would therefore certainly be necessary for intelligences very much lower in the scale, did such exist. Thus the so-called 'intelligence,' 'understanding,' and 'knowledge' of animals are not really intelligence, understanding, and knowledge. They are but sensuous simulations of such intellectual faculties.

The distinction between the human mind and the highest animal powers will be yet more clearly seen if we reconsider our perception of the qualities of objects. A dog may feel another dog as formidable, because courageous; but he will have no idea of 'courage' or 'courageousness' in the abstract. Many animals, even insects, will distinguish clearly between objects of different colours-the white from the blue, the red from the yellow--but no animal knows whiteness or blueness, or the conception 'colour.' Yet every savage who rewards a youth of his tribe for a brave action, or who smears his body with pigments, thereby shows us that these abstract ideas are familiar to him. Only the human mind has, and every human mind has, the power of making an abstract quality a direct and a distinct object of thought.

Thus it is that a most marked difference, a difference not of degree but of kind, divides men from all, even the highest brutes. There is a limit to evolution between human and 
merely animal nature, and something altogether new, a capacity for apprehending abstract ideas, first appeared on this planet with the coming of man.

This consequence indisposes many persons to recognise the fact of man's fundamentally different nature. They feel they cannot imagine man's distinct origin. Of course they cannot, for they have had no experience of anything of the kind. The present writer cannot in the least imagine it. But inability to imagine a thing is no ground whatever for not believing that thing, if reason supplies us with good evidence in its favour. We continually accept as true things we cannot imagine, and we do so very properly. No one can imagine the 'validity' of an argument logically deduced from its principles, but we none the less accept it and act on it. Many persons believe that our world, together with the whole solar system, once consisted of incandescent matter and was utterly devoid of life: if they are right, then the coming of life, when it came, must have constituted a new departure. If the first living creatures were plants of some kind, and were without any power of feeling, then the coming of sentient life, when it came, must have been another break in continuity. So also with the advent of rationality! But had we been present at man's advent we might have seen nothing whatever miraculous about it. The essence of humanity is reason acting as here described. It is not man's bodily shape. His body, with all its processes of nutrition, feeling, development, etc., is undoubtedly like that of some sort of ape. But man's mere body is not man. If Swift's tale about the Houyhnhnms and Yahoos was true, it would be the horse-shaped Houyhnhnms who would be the true men and the man-shaped Yahoos, the true brutes. Let, then, the progeny of some mere animal have acquired, or had infused into them-by some unimaginable process-the idea of 'being' and the power of perceiving the qualities of 
objects and their kinds, and such creatures would at once be men, even if unable to articulate, and only able to give in the most rudimentary way, bodily expression to their incipient ideas.

And now, in concluding, we would advert to a difficulty which has perhaps impressed not a few readers. They may very reasonably ask, How is it, if the doctrine of man's evolution is thus rationally untenable, that so many scientific men-learned zoologists and anatomists-hold it? The answer is, that the question of man's origin is a philosophic, not a scientific question, and that men may be very distinguished for scientific knowledge and yet be the victims of a very defective philosophy. Such is conspicuously the case in the present instance. The Darwinian view is supported by men, and only by men, who confound 'ideas' with 'faint revivals of past feelings.' It is on this account that not one of them has grappled with the essence of the question. But no progress can really be made in investigating the problem of man's origin except by those who have gained a true knowledge of what man is now. The present writer is profoundly convinced that the more deeply and thoroughly human nature is studied, the more clear and decisive will be the conviction arrived at, that the powers of mental abstraction, and of language, which is its external sign, mark the most interesting and impassable limit to evolution. 


\section{ORGANIC NATURE'S RIDDLE.}

$A$ MONGST the many sagacious sayings of the patient and A profound thinkers of Germany, not the least noteworthy was Schelling's affirmation that the phenomena of instinct are some of the most important of all phenomena, and capable of serving as a very touchstone whereby the value of competing theories of the universe may be effectually tested. His prescience has been justified by our experience. The greatest scientific event of the present time is the wide acceptance of the theory of Evolution, and its use as a weapon of offence and defence. It is used both against the belief that intelligent purpose is, as it were, incarnate in the living world about us, and also in favour of a merely mechanical theory of nature. Now it would be difficult to find a more searching test of that theory's truth than is supplied by a careful study of instinct. The essence of that view of nature which is associated with the name of Professor Haeckel, ${ }^{1}$ consists in a negation of the doctrine of final causes and an assertion of what he calls 'Dysteleology,'- that is, the doctrine of the purposelessness of the organs and organisms which people a purposeless planet. ${ }^{2}$ That doctrine may be called the gospel of the irrationality of the universe, and it is a doctrine to

${ }^{1}$ It is often associated unfairly with the illustrious name of the late $\mathrm{Mr}$. Darwin. His special views lend themselves indeed to Haeckelianism, and have been pressed into its service; yet they are by no means to be identified therewith.

${ }^{2}$ See ante, p. 268. 
which a proof of the real existence of such a thing as 'instinct' must necessarily be fatal. Instinct has been defined $^{1}$ as a 'special internal impulse, urging animals to the performance of certain actions which are useful to them or to their kind, but the use of which they do not themselves perceive, and their performance of which is a necessary consequence of their being placed in certain circumstances.' Such an impulse is always understood to be the result of sensations; actions which take place in response to unfelt stimuli being referred, not to instinct, but to what is termed reflex action. In such action it is commonly supposed that the mechanism of a living body occasions a prompt responsive muscular movement upon the occurrence of some unfelt stimulation of the nervous system. The nervous system, or total mass of nerve-stuff-which is technically called 'nerve-tissue' - in the body of an animal, such as a beast, bird, reptile, or fish, is composed of two parts or divisions. One of these divisions consist of a voluminous and continuous mass - the brain and spinal cord (or spinal marrow), which form what is called the central part of the nervous system. The second division consists of a multitude of white threads or cords-the nerves, which form what is called the peripheral part of the nervous system. Of these nerves one set proceed forth from the central part of the nervous system to the different muscles, which they can cause to contract by a peculiar action they exert upon them, thus producing motion. Another set of nerves proceed inwards, from the skin to the central part of the nervous system, and by their peculiar action give rise to various sensations, according as different influences or stimulations are brought to bear upon the skin at, or in the vicinity of, their peripheral extremities. Under ordinary circumstances, different stimulations of the surface of the body convey an influence inwards, which produces

${ }^{1}$ See Todd's Cyclopadia of Anatomy and Physiology, vol. iii. p. 3. 
sensation, and gives rise to an influence proceeding outwards to the muscles, resulting in definite and appropriate motions.

There are cases in which responsive actions take place under very abnormal conditions - as after a rupture of part of a man's spinal cord, or the removal of the whole brain in lower animals, such as the frog. A man so injured may have utterly lost the power of feeling any stimulation-pricking, cutting, or burning - of his legs and feet, the injury preventing the conveyance upwards to the brain of the influence necessary to produce sensation, and arresting it in the spinal cord below the point of injury. Nevertheless, such a man may execute movements in response to stimuli just as if he did feel, and often in an exaggerated manner. He will withdraw his foot if tickled with a feather, just as if he felt the tickling, which he is utterly incapable of feeling. Similarly a decapitated frog will make with his hind legs the most appropriate movements to remove any irritating object applied to the hinder part of its body. Such action is termed 'reflex action,' on the supposition that the influence conveyed inwards by nerves going from the skin to the spinal cord is reflected back from that cord to the muscles by the other set of nerves without any intervention of sensation. This action of the frog may be carried to a very singular extreme. At the breeding season the male frog tightly grasps the female behind her arms, and to enable him the more securely to maintain his hold, a warty prominence is then developed on the inner side of each of his hands. Now if such a male frog be taken, and not only decapitated, but the whole hinder part of the body removed also, so that nothing remains but the fragment of the trunk from which the two arms with their nerves proceed, and if under these circumstances the warty prominences be touched, the two arms will immediately close together like a spring, thus affording a most perfect example of reflex action. It 
has been objected (by the late Mr. G. H. Lewes and others) that we cannot be sure but that the spinal cord itself 'feels.' But there is often an ambiguity in the use of the term 'to feel.' By it we ordinarily mean a 'modification of consciousness'; but experiences such as those just adverted to, and others in ourselves to which I shall next advert, show clearly that surrounding agents may act upon our sense organs without the intervention of anything like consciousness, and yet produce effects otherwise similar to those which occur when they do arouse consciousness. Without, then, entering into any discussion as to whether 'sentiency' may or may not be attributed to the spinal cord, it seems evident that some definite term is required to denote such affections or modifications of living beings as those just referred to. Inasmuch as they are affections of creatures possessing a nervous system, which is the essential organ of sensation, and as they resemble sensation in their causes and effects though feeling itself may be absent, they may be provisionally distinguished as 'unfelt sensations.' Such are some of the actions with which instinct is contrasted, because, unlike instinct, they are not carried on by the aid of felt sensations, the highest of such insentient action being reflex action.

There are also a number of actions which constantly recur in ourselves, which more or less nearly approximate to reflex action. Thus the respiratory movements, the various muscular motions by the aid of which we breathe, are ordinarily performed by us without advertence; though we can, if we will, perform them with self-conscious deliberation. It is well also to note that when our mind is entirely directed upon some external object, or when we are almost in a state of somnolent unconsciousness, we have but a vague feeling of our existence-a feeling resulting from the unobserved synthesis of our sensations of all orders and degrees. This unintellectual sense of 'self' may be conveniently dis- 
tinguished from intellectual consciousness as ' consentience.' We may also, as everybody knows, suddenly recollect sights or sounds which were quite unnoticed at the time we experienced them; yet our very recollection of them proves that they must, nevertheless, have affected our sensorium. ${ }^{1}$ Such unnoticed modifications of our sense organs may also be provisionally included in the category of those actions of the lower animals, before provisionally denominated 'unfelt sensations.' It is not, however, with such inferior activities as reflex and other insentient actions that instinct is commonly contrasted, but with 'reason.' Now 'reasonable,' 'consciously intelligent' conduct is understood by all men to mean conduct in which there is a more or less wise adaptation of means to ends-a conscious, deliberate adaptation, not one due to accident only. No one would call an act done blindly a reasonable or intelligent action on the part of him who did it, however fortunate might be its result. Instinctive actions, then, hold a middle place between (1) those which are rational, or truly intelligent, and (2) those in which sensation has no place. But a great variety of actions of different kinds occupy this intermediate position, and we must next proceed to separate off from the others such actions as may be deemed truly instinctive.

M. Albert Lemoine, who has written the best treatise ${ }^{2}$ known to us on instinct and habit, distinguishes instinctive actions as those which are neither due to mechanical or chemical causes, nor to intelligence, experience, or will. They are actions which take place with a general fixity and precision, are present in all the individuals of each species, and can be perfectly performed the very first time their action is called for, so that they cannot be due to habit. Instinct, he very truly says, is more than a want and less than a desire. Instinct is a certain felt internal

${ }^{1}$ See ante, p. 220. $\quad{ }^{2}$ L'Habitude et l'Instinct. Baillière. Paris, 1875. 
stimulus to definite actions which has its foundation in a certain sense of want, but is not a definite feeling of want of the particular end to be attained. Were that recognised, it would not be instinct, but desire. It is but a vague craving to exercise certain activities the exercise of which conduces to useful or needful, but unforeseen, ends. Instinct often sets in motion organs quite different from those which feel the prick of want, and which do not (experience apart) seem to have relation with it. Hunger does not stimulate to action the organs of digestion which suffer from it, but excites the limbs and jaws to perform acts by which food may be obtained and eaten. In examining into instinct, we must be careful not to omit the consideration of it as it exists in man, since we can know no creature so well as we can, by the help of language and reflection, know ourselves and our own species. Nevertheless, it may be well to begin by calling attention to certain apparently undeniable cases of instinct in other animals, since in them instinct is much more apparent and complex than in man, in whom it is indeed reduced to a minimum. It might naturally be expected to be so reduced in himif it is a power serving to bridge over the gulf which exists between such almost mechanical action as reflex action, and true intelligence-since in man acts of intelligence, or habits originated through intelligence, come so constantly into play. But before enumerating cases of animal instinct, a word should be said as to one character which M. Lemoine attributes to instinctive action, namely, 'consciousness.' This term is an exceedingly ambiguous one, as it is often referred, not only to our distinct intellectual perception of our own being and acts, but also to every state of feeling however rudimentary it may be. I would therefore avoid the use of so equivocal a term, while fully admitting that no sensation in any animal is possible without some subjective 
psychical state analogous to what I have before denominated 'consentience.' Now, as to the lower animals : birds unquestionably possess instinctive powers. Chickens, two minutes after they have left the egg, ${ }^{1}$ will follow with their eyes the movements of crawling insects, and peck at them, judging distance and direction with almost infallible accuracy. They will instinctively appreciate sounds, readily running towards an invisible hen hidden in a box, when they hear her 'call.' Some young birds, also, have an innate, instinctive horror of the sight of a hawk and of the sound of its voice. Swallows, titmice, tomtits, and wrens, after having been confined from birth, are capable of flying successfully at once, when liberated, on their wings having attained the necessary growth to render flight possible. The Duke of Argyll $^{2}$ relates some very interesting particulars about the instincts of birds, especially of the water ousel, the merganser, and the wild duck. Even as to the class of beasts the following case has been recorded: ' 'Five young polecats were found comfortably embedded in dry withered grass; and in a side hole, of proper dimensions for such a larder, were forty frogs and two toads, all alive, but merely capable of sprawling a little. On examination the whole number, toads and all, proved to have been purposely and dexterously bitten through the brain.' Evidently the parent polecat had thus provided the young with food which could be kept perfectly fresh, because alive, and yet was rendered quite unable to escape. This singular instinct is like others which are yet more fully developed amongst insects - a class of animals the instincts of which are so numerous, wonderful, and notorious that it will be, probably, enough to refer to one or two examples. The female carpenter bee, in order to

1 As Mr. Spalding has shown. To him I am indebted for the other facts about young birds given in the text.

2 The Unity of Nature, chap. iii.

${ }^{3}$ See Magazine of Natural History, vol. vi. p. 206.

VOL. II. 
protect her eggs, excavates, in some piece of wood, a series of chambers, in special order, with a view to a peculiar mode of exit for her young: but the young mother can have no conscious knowledge of the series of actions subsequently to ensue. The female of the wasp sphex affords another well-known but very remarkable example of a complex instinct closely related to that already mentioned in the case of the polecat. The female wasp has to provide fresh, living animal food for her progeny, which, when it quits the egg, quits it in the form of an almost helpless grub, utterly unable to catch, retain, or kill an active, struggling prey. Accordingly the mother insect has not only to provide and place beside her eggs suitable living prey, but so to treat it that it may be a helpless, unresisting victim. That victim may be a caterpillar, or it may be a great, powerful grasshopper, or even that most fierce, active, and rapacious of insect tyrants, a fell and venomous spider. Whichever it may be, the wasp adroitly stings it at the spot which induces, or in the several spots which induce, complete paralysis as to motion, let us hope as to sensation also. This done, the wasp entombs the helpless being with its own egg, and leaves it for the support of the future grub. Another species feeds her young one from time to time with fresh food, visiting at suitable intervals the nest she has made and carefully covered and concealed with earth, which she removes and replaces, as far as necessary, at each visit. If the opening be made ready for her, this, instead of helping her to get at her young, altogether puzzles her, and she no longer seems to recognise her brood, thus showing how thoroughly ' instinctive' her proceedings are. Other instances of instinct, such as those of the stag-beetle and emperor moth, I will refer to presently. But most wonderful, perhaps, of all are the instincts of social insects, such as bees, where there are not only males and females, but a large population of prac- 
tically neuter insects, the special instincts and peculiarities of which have of course to be transmitted not directly by an antecedent set of neuter animals, but by females, the instincts and peculiarities of which are very different from those of the neutral portion of their progeny.

The instincts we have hitherto referred to, and, I may say briefly, the instincts of animals generally, are destined to subserve two functions, (1) the preservation and, mainly, the nutrition of the individual, and (2) the reproduction of the species. Armed with the facts we have now noticed, let us turn to consider instinct as it displays itself in ourselves. As one example, there is the instinctive action by which an infant first sucks the nipple, and then swallows the thenceextracted nourishment with which its mouth is filled. This action must be reckoned as instinctive, because it is done directly after birth, when there has been no time for learning to perform the action; it is one absolutely necessary for the life of the infant; it is an action which is definite and precise, similarly performed by all the individuals of the species, though effected by a very complex mechanism, and it is effected prior to experience. Yet it is not as mechanical as reflex action, for not only sensation, but consentience, accompanies the act. Thus sucking in man is an instinctive action, while spitting, on the other hand, is an art. The latter is not necessary to life, and the power of performing it is slowly acquired by experience, as are also our powers of walking and feeding ourselves. But the action of sucking in an adult human being is of course not instinctive; and because the child learns to walk, it by no means follows that the insect learns to fly. It is thus plain that actions may be instinctive in one animal and not in another; or at one period of life in the same animal and not at another. In a child, however, sucking, deglutition, inspiration, and expiration are instinctive actions, as are also those by which 
the products of excretion are removed from the body. The second class of instincts, those which ensure the continuance of the race, show themselves of course, only much later. Yet, long before the little girl can represent to herself future tributes to her charms, she seeks to decorate her tiny body with the arts of infant coquetry. Still less does she look forward to the pains and pleasures of maternity when she begins to caress and chastise, to soothe and cherish, her first doll, and fondly presses it to that region whence her future offspring will draw its nourishment. Again, when the lapse of a few years having made her a young woman and the boy a youth, they first feel the influence of love, however ignorant they may be of the physiology of their race, they will none the less, circumstances permitting, be surely impelled towards the performance of very definite actions. In the more refined individuals of the highest races of mankind, the material, merely animal, consummation of sexual love is most certainly far from being the one great end distinctly looked forward to by each pair of lovers. Yet every incident of affectionate intercourse, every tender glance, every contact of hand or lip, infallibly leads on towards the one useful end, indispensable to the race, which nature has in view. Such actions fully merit to be called 'instinctive.' Indeed the act of generation is ministered to in nature by the most manifold, imperious, general, and inexplicable of all the instincts, and its instinctive character is the most strongly marked of all. It has emphatically for its origin a rigorously determined and precise want, partly painful, partly pleasurable-a mixture of a feeling of privation with a sense of power. Its end is unknown to the agent, or if known is disregarded, and in almost all animals it demands the concurrent and reciprocal action of two diverse organisms. If any one would deny that it is instinctive in man, I would advise him to study the sad 
phenomena connected therewith which may be observed in our asylums for the insane.

There are other human actions which are sometimes reckoned as instinctive, such as guarding the eye against injury by suddenly closing the eyelids. This action, however, appears to be an acquired art, though the habitual act of winking to keep clean the surface of the eye may be instinctive. Some other actions, however, not generally regarded as instinctive, I should be disposed so to regard. Such are the first active exercises of the senses of seeing, hearing, smelling, tasting, and feeling (the first 'looking,' the first' listening,' etc.) which the child performs at the very beginning of its learning to perform them. It would seem, then, as if no one could deny the existence of such a thing as instinct, and yet it has been denied, not only in recent times, but centuries ago. Thus Montaigne sought to explain instinct as but a form of intelligence, while Descartes taught that it was but mechanism. Condillac regarded it as the result of individual experience, and Lamarck considered it to be merely 'habit' which had become hereditary. In our own day Darwin has sought to explain it as partly the result of accidental variations of activity, which variations have become naturally selected, and partly the result of intelligent, purposive action which has become habitual and inherited. Let us consider these attempts at explanation seriatim. First as to mechanism: This is an hypothesis no one at present entertains, as every one now credits animals with sensitivity. Moreover, instincts are not absolutely invariable, but are modifiable according to the degree of 'intelligence' which animals possess. They cannot, therefore, be due merely to a mechanism. The attempt to explain 'instinct' by mere 'reflex action' is equivalent to an attempt to explain a phenomenon by omitting its most striking characteristic. In 'reflex action' we have a sudden 
response to a stimulus, which response is more or less purposive as regards the time of its occurrence, but has no reference to future events to occur long after the faintest waves of the stimulating action have died out. The very essence of 'instinct,' however, is to provide for a more or less distant future, often, as we have seen, the future of another generation. It is essentially telic, and directed to a future unforeseen, but generally useful, end. This explanation, then, is fundamentally and necessarily inadequate. It is like an explanation of the building of a house, by 'bricks, mortar, bricklayers, and hodmen,' with the omission of all reference to any influence governing their motions and directing them towards a common and predetermined end which is not theirs. But though we cannot explain 'instinct' by 'reflex action,' there is none the less a certain obvious affinity between these two forms of animal activity, and it is in part my object to point out the nature of this very affinity.

Next we may pass in review the two hypotheses that instinct is but (1) a form of intelligence, or (2) individual experience. As to the first, I have already given instances of unquestionably instinctive actions performed by birds as soon as they quit the eggshell, and it would be but waste of time to argue against the view that the human infant is guided by intelligent purpose and conscious foresight in his very first acts of sucking, swallowing, and defecation. Actual intelligence, therefore, is a radically insufficient explanation, as also, for the very same reasons, is Condillac's hypothesis as to individual experience. About 'lapsed intelligence' I will speak later on. Lamarck's hypothesis, that instinct is but inherited habit, is one which is much more worthy of careful consideration than any we have yet considered. For it may be admitted at once that habits may be inherited. There are many in- 


\section{Organic Nature's Riddle}

stances of such inheritance in human beings, and as regards the lower animals, the barking of dogs may be taken as an instance of a habit thus perpetuated. In fact 'habit,' when inherited, so simulates instinct, that their confusion is far from surprising. There is, however, this radical difference between them: 'habit' enables an agent to repeat with facility and precision an act which has been done before, but 'instinct' determines with precision the first performance of such act. Referring instinct to habit but temporarily relieves the difficulty of those who object to instinct, by putting it a step back. It is impossible to believe that any of the progenitors of an infant of to-day first acquired, during his or her lifetime, the habit of sucking, or that the habits of neuter insects thus arose. But after all, if we could explain 'instinct' by 'habit,' should we thereby make the phenomena less mysterious? 'Habit' is due to an internal spontaneity of living things. A living thing no doubt requires some internal solicitation, in order that it should move, but when it does move that movement is its own. All living organisms tend to act. With them action is not only their nature, 'tis a want; and, within limits, their powers and energies increase with action, and diminish and finally perish through repose. The power of generating any 'habit,' lies in the very first act of the kind an organism performs, and it is only the first act which owes nothing to habit. If such were not the case, an act might be performed a thousand times and yet not generate habit. It is this mysterious internal active tendency which distinguishes all living organisms from inorganic bodies. The latter tend simply to persist as they are, and have no relations with the past or the future. They have, therefore, no relations with time at all-for the actual present ever evades us. Organisms, on the other hand, which are permanently more or less changed, through habit, by every new motion and sensation, have 
their future prepared by their past, and thus, as it were, at every present moment they live both in the past and in the future, a mode of existence which attains its fullest development in the highest living organism-man, the creature looking before and after! Thus those who would do away with mystery in nature would gain little by explaining instinct through habit, though, as we have seen, the phenomena presented to us by the human infant and by neuter insects absolutely bar any such explanation. Moreover, the attempt to explain 'instinct' through 'inheritance' is a contradiction, since 'inheritance' supposes something already obtained, otherwise it could not be transmitted. So far, then, from ' hereditary transmission' explaining 'instinct,' instinct, in whatever remote ancestor it first arose, must have been a violation of the law of hereditary transmission.

Now as to 'lapsed intelligence': This hypothesis assumes that a conscious, deliberate, discriminating faculty must have once been exercised by wasps, bees, ants, and other much more lowly animals, in the performance of all those actions which are now instinctive. But could the adult female insect be supposed to foresee the future needs of her first progeny, often so totally different from her own wants? It would surely be too much to ask us to believe that she could distinctly recollect all her past experience as a chrysalis and as a grub from the moment she first quitted the egg. Can we suppose that the generative acts of male insects, such as bees, could have been due to deliberate and rational choice, when every such act is necessarily fatal to him who performs it?

Nevertheless; persuaded as I am that 'lapsed intelligence' will not explain 'instinct' generally, I should be the last to deny that certain apparently instinctive actions may be so explained, and I fully admit that intelligent action in ourselves does tend to become practically though not really 
instinctive. It is, moreover, very fortunate for us that such is the case, as thereby we are saved great mental friction. Our intellect has first to be laboriously applied to learn what afterwards becomes almost automatic, as the actions of reading, writing, etc. Sensations and bodily actions having been duly kneaded together, the intellect becomes free to withdraw and apply itself to other work-fresh conquests over mere animality-leaving the organism to carry on automatically the new faculties thus acquired. Were it not for this power which we have of withdrawing our attention, our intellect would be absorbed and wasted in the merest routine work, instead of being set free to appropriate and render practically instinctive a continually wider and more important range of deliberate purposive actions.

We come now to the sixth and last attempt to explain instinct, namely, Mr. Darwin's attempt. He has recognised the futility of seeking to explain many instinctive actions in any of the modes we have yet considered, and he has proposed, as before said, to explain such residual instinctive phenomena by the play of natural selection, i.e. of the destructive forces of nature upon small, accidental abnormalities of action on the part of individuals of a species; such abnormalities, when favourable to the existence of the individual, being preserved and perpetuated by the destruction of the other individuals of the same species who adhered to their ancestral tendencies. But this proposed explanation is not an explanation of the origin of instincts, but only of the changes and transformations of instincts already acquired. But putting back the date or modifying the form of the original instinct in no way alters the essential nature of instinct or diminishes its mystery. Let us look at one or two strong cases of instinct, and see if it is credible that they should be due to mere accidental, haphazard, minute changes in habits already acquired. In the first place, there is the wonderful instinct 
of the duck, which feigns to have an injured wing in order to entice a dog away from the pursuit of her ducklings. Is it conceivable that such an act was first done by pure accident, and that the descendants of her who so acted, having inherited the tendency, have been alone selected and preserved? Again, there is the case of the wasp sphex, which stings spiders, caterpillars, and grasshoppers exactly in the spot, or spots, where their nervous ganglia lie, and so paralyses them. Even the strongest advocate of the intelligence of insects would not affirm that the mother sphex has a knowledge of the comparative anatomy of the nervous system of these very diversely formed insects. According to the doctrine of natural selection, either an ancestral wasp must have accidentally stung them each in the right places, and so our sphex of to-day is the naturally selected descendant of a line of insects which inherited this lucky tendency to sting different insects differently, but always in the exact situation of their nervous ganglia; or else the young.of the ancestral sphex originally fed on dead food, but the offspring of some individuals who happened to sting their prey so as to paralyse but not kill it were better nourished, and so the habit grew. But the incredible supposition that the ancestor should accidentally have acquired the habit of stinging different insects differently, but always in the right spot, is not eliminated by the latter hypothesis.

There is, again, the case of neuter insects and the highly complex instincts of insects living in communities, such as bees, ants, and termites. The Darwinian theory has the great advantage of only needing for its support the suggestion of some possible utility in each case; and as all structures and functions in nature have their utility, the task is not a difficult one for an ingenious, patient, and accomplished thinker. Yet Mr. Darwin, with all his ingenuity, patience, 
and accomplishments, has been unable to suggest a rational explanation for the accidental origin of these insect communities with their marvellously complex instincts. I will confine myself to one more instance of a highly noteworthy instinct, which no one has in any way succeeded in explaining. The instance I refer to is that by which an animal, when an enemy approaches, lies quite quiescent and apparently helpless, an action often spoken of as 'shamming death.' To evade the force of this remarkable case of instinct, it has been objected that the disposition of the limbs adopted by insects which thus act, is not the same as that which the limbs assume when such insects are really dead, and that all species are not when thus acting equally quiescent. The first observation, however, does not concern the matter really at issue. The remarkable thing is not that a helpless insect should assume the position of its own dead, but that such a creature, instead of trying to escape, should adopt a mode of procedure utterly hopeless unless the enemy's attention is thereby effectually eluded. It is impossible that this instinct could have been gradually gained by the elimination of all those individuals who did not practise it, for if the quiescence, whether absolutely complete or not, were not sufficient at once to make the creature elude observation, its destruction would be only the more fully insured by such ineffectual quiescence. The same argument applies to birds which seem to feign lameness or other injury. Yet even if we could account for these cases, which as a fact are as yet entirely unaccounted for, it would not do away with the need of recognising the real existence and peculiar nature of instinct. It would not do so on account both of man's highest and of man's lowest instinctive powers. To speak first of the former: as instinct, such as we have hitherto discovered, is the appointed bridge between mere organic and intellectual animal life, so there 
is in man a further development of instinct, peculiar to him, and serving to bridge over the gulf between mere intelligent animal faculty and distinctly human reflective intellectual activity. Such special intellectual instinct is that which impels man to the external manifestation by voice or gesture of the mental abstractions which his intellect spontaneously forms, and which are not formed by the lower animals, which give no evidence of this power of abstraction. Language could never have been deliberately invented nor have arisen by a mere accidental individual variation, for vocal and gesture signs are essentially conventional, and require more or less comprehension on the part of those to whom they are addressed as well as on the part of those who use them. Analogous considerations apply to the first beginnings of what cannot be reckoned as merely instinctive activities, but the origins of which must have been akin to instincts. I refer to the beginnings of literature, art, science, and politics, which were never deliberately invented. Even men who supposed they were inventing and constructing a certain new order of things with full purpose and much intelligence, have really been all the time so dominated by influences beyond their consciousness, that they really evolved something very different from what they supposed or intended. This fact has been most instructively shown by De Tocqueville and Taine with respect to the men who promoted and carried through the great French Revolution. So much, then, for man's highest instinctive powers: but our argument has no need to refer to them, for a consideration of man's lowest instinctive powers alone suffices to show that they cannot be due to 'natural selection,' even when aided by 'lapsed intelligence.' Can it be for a moment seriously maintained that such actions of the infant as those of the sucking, deglutition, and defecation, or the sexual instincts of later life, ever arose through the accidental conservation of hap- 
hazard variations of habit in ancestral animals ? If it cannot be maintained, as I am confident it cannot, then it is absolutely impossible successfully to evade the difficulty of the existence of instinct. However far we may put back the beginnings of instinct, the question as to its origin (with its subsequent modifications) ever returns, and indeed with increased importunity. How did the first sentient creatures obtain and swallow their food? How did they first come to fecundate their ova or suitably to deposit them? How did they first effect such movements as might be necessary for their respiratory processes ? Wherever such phenomena first manifested themselves in sentient organisms, we are compelled therein to recognise the manifest presence of instinct - the appointed means (as before said) of bridging over the interval between the purely vegetative functions and the intelligent activities of sentient animal life. 'Natural selection' is manifestly impotent to account for the existence of such a faculty as that of 'instinct.' We have already seen that the hypothesis of 'lapsed intelligence' is also impotent to account for it. Thus the most recently attempted explanation falls altogether to the ground. Nevertheless the theory of Evolution renders it necessary to assume that as new species of animals were from time to time evolved, so also were new and appropriate instincts. How then are we to account for the origin of such new instincts ? That a certain mystery attends such origin cannot be denied, but a parallel mystery attends all other kinds of vital phenomena. What can be more mysterious than the purely organic functions of animals? Though not truly instinctive, they are full of unconscious purpose, and so are akin to instinct. Our nutrition is a process of self-generation by which the various matters which constitute our food become transformed into our own substance. This process is effected by what is called assimilation, by which process the ultimate substance, 
or parenchyma, of our own body transforms part of what is immediately external to it into the parenchyma itself. Again, the process of secretion is, as it were, parallel to the process of alimentation or nutrition. In secretion, the body extracts from the blood new substances (the secretions) which do not exist as such within it. In nutrition, the body extracts from the blood new substances (the various tissues) which do not exist as such within it. The blood is not the only source of our nutrition, since it has the power of replenishing itself. Thus the living particles which form the ultimate substance of our body exercise a certain power of choice with respect to the contents of the fluids which come in contact with them. Such particles are not passive bodies; they are active living agents, and their action no one has yet really explained. Here, then, are a set of activities which, if duly pondered over, will be found to be fully as mysterious and inexplicable in their unconscious teleology as any phenomena of instinct as ordinarily understood. But there is another class of organic vital actions which also seem to have a decided affinity both to reflex action and to instinct, though they are not to be regarded as actual instances of either of these faculties. The actions I refer to are those which bring about the repair of injuries and the reproduction of lost parts. They are like reflex action inasmuch as they take place in perfect unconsciousness and without the will having any power over them. They are like instinct inasmuch as they are directed towards a useful and unforeseen end. In the process of healing and repair of a wounded part of the body, a fluid, perfectly structureless substance, is secreted, or poured forth, from the parts about the wound. In this substance cells arise and become abundant; so that the substance, at first structureless, becomes what is called cellular tissue. Then, by degrees, this structure transforms itself into vessels, tendons, nerves, 


\section{Organic Nature's Riddle}

bone, and membrane-into some or all of such partsaccording to the circumstances of the case. In a case of broken bone, the two broken ends of the bone soften, the sharp edges thus disappearing. Then a soft substance is secreted, and this becomes at first gelatinous, often afterwards cartilaginous, and, finally, osseous or bony. But not only do these different kinds of substance-these distinct tissues -thus arise and develop themselves in this neutral, or, as it is called, 'undifferentiated' substance, but very complex structures, appropriately formed and nicely adjusted for the performance of complex functions, may also be developed. We see this in the production of admirably formed joints in parts which were at first devoid of anything of the kind. I may quote, as an example, the case of a railway guard, whose arm had been so injured that he had been compelled to have the elbow with its joint cut out, but who afterwards developed a new joint almost as good as the old one. In the uninjured condition the outer bone of the lower armthe radius-ends above in a smooth-surfaced cup, which plays against part of the lower end of the bone of the upper arm, or humerus, while its side also plays against the side of the other bone of the lower arm, the ulna, with the interposition of a cartilaginous surface. The radius and ulna are united to the humerus by dense and strong membranes or ligaments, which pass between it and them, anteriorly, posteriorly, and on each side, and are attached to projecting processes; one on each side of the humerus. Such was the condition of the parts which were removed by the surgeon. Nine years after the operation the patient died, and Mr. Syme had the opportunity of dissecting the arm, which in the meantime had served the poor man perfectly well, he having been in the habit of swinging himself by it from one carriage to another, while the train was in motion, quite as easily and securely as with the other arm. On examination, Mr. Syme 
found that the amputated end of the radius had formed a fresh polished surface, and played both on the humerus and the ulna, a material something like cartilage being interposed. The ends of the bones of the forearm were locked in by two processes projecting downwards from the humerus, and also strong lateral and still stronger anterior and posterior ligaments again bound them fast to the lastnamed bone. ${ }^{1}$ It would be easy to bring forward a number of more or less similar cases. The amount of reproduction of lost parts which may take place in many of the lower animals is astonishing. Thus the tails of lizards, if broken off, will grow again, and the limbs of newts will be reproduced, with their bones, muscles, blood-vessels, and nerves. Even the eye and the lower jaw have been seen to be reproduced in the last-named animals. If certain worms be cut in two, each half will become a perfect animal, the head producing a new tail, and the tail a new head; and a worm called a nais has been cut into as many as twenty-five parts with a like result. But the most remarkable animal for its power of repairing injuries is the fresh-water hydra, almost any fragment of which will, under favourable circumstances, grow into a new and entire fresh animal. It is also a notorious and very noteworthy fact that, in both man and the lower animals, the processes of repair take place the more readily the younger the age of the injured individual may be. But these unconscious, yet practically teleological processes of repair, are often preceded by actions which every one would call instinctive.

There is yet another class of organic vital actions to which I must advert, which are at once utterly unconscious, while the fact that they are directed to a distinct end is indisputable; in fact they are purposive, in the very highest degree that any unconscious actions can be purposive. They

1 See Mr Timothy Holmes's System of Surgery, 3rd edit. vol. iii. p. 746. 
are the actions- of true reproduction, and they come before us naturally here, since a consideration of the process of remedial reproduction in the individual, naturally leads us on to the consideration of the reproduction of the species itself. In the cases of the frog and the butterfly, every one knows that the creature which comes forth from the egg is very different from the parent. Animals, in fact, mostly attain their adult condition by passing through a series of developmental changes; only as a rule that series is not abruptly interrupted by plainly marked pauses, as it is in the frog and butterfly, and, therefore, such changes, instead of being obvious, are only to be detected with difficulty and through patient research. Almost every animal thus goes through a series of very remarkable changes during its individual process of development, or, as it is called, during its 'ontogeny.' This process, in its perfect unconsciousness, is like reflex action, but it is far more wonderful, since in the earliest stages even nerve-tissue is absent and has itself to be formed. In the accuracy of its direction towards a useful end, it is the very counterpart of the most developed instinct; nor, if the impulses by which adult individuals are led to seek and to perform those processes which give rise to the embryo are to be called instinctive, is it easy to see how the analogical use of the term 'instinctive' can be refused to that impulse by which each developing embryo is led to go through those processes which give rise to the adult. The action of each organism during its individual development may be compared, and has evidently much affinity with, the processes of nutrition and the repair and reproduction of parts lost through some injury. These processes of nutrition and repair have also evidently a close relation to reflex action, and reflex action has also a close affinity to instinctive action. Instead, however, of explaining ' instinct' by 'reflex action,' I would rather explain reflex

VOL. II. 
action, processes of nutrition, processes of repair, and processes of individual development, by instinct-using this term in a wide analogical sense. For we know the wonderful action and nature of instinct as it exists in our own human activity, standing, as it were, at the head of the various unconsciously intelligent vital processes. These processes seem to me to be all diverse manifestations of what is fundamentally one kind of activity. Of these manifestations, instinctive action is the best type, because by it we can, to a certain extent, understand the others, whereas none of the others enable us to understand instinct.

A thoroughly mechanical conception of nature is the scientific ideal of a very large and a very influential school of thinkers, ${ }^{1}$ and the goal towards which they strive. In so striving they follow the lead of the earliest of modern philosophers, Descartes, who would probably have felt no small satisfaction could he have foreseen that the doctrine of animal automatism would be so eloquently advocated in the nineteenth century, as well as that of a mechanical evolution of new species of animals and plants.

Evidently the last-mentioned conception was necessary to render the mechanical theory complete. As long as men believed in the action of any mysterious intelligence hidden in nature, and working through it in specific evolution towards foreseen and intended ends, a mechanical conception of nature was obviously impossible. But no less impossible

1 Thus Kirchhoff has said (Prorectoratsrede; Heidelberg, 1865), "The highest object at which the natural sciences are constrained to aim is the reduction of all the phenomena of nature to mechanics'; and Helmholtz has declared (Populär-Wissenschaftliche Vorträge, 1869), 'The aim of the natural sciences is to resolve themselves into mechanics.' Wundt observes (Lehrbuch der Physiologie des Menschen), "The problem of physiology is a reduction of vital phenomena to general physical laws, and ultimately to the fundamental laws of mechanics'; while Haeckel tells (Freie Wissenschaft und freie Lehre) that 'all natural phenomena, without exception, from the motions of the celestial bodies to the growth of plants and the consciousness of men, . . . are ultimately to be reduced to atomic mechanics.' 
was the acceptance of such a mechanical hypothesis as long as any belief remained in the existence, in individual animals, of an innate and mysterious instinctive power directing their actions in ways beneficial to them or to their race, yet unintended and unforeseen by the creatures which performed those actions. A denial of the existence of any true 'instinct,' as well as of any unmechanical action in specific evolution, was then necessary for the maintenance of the mechanical theory, and accordingly such denials have been confidently made, as we have already seen.

While, however, this current of thought has been gaining in volume and velocity, another contrary current has no less made itself manifest, and amongst its exponents Edward Von Hartmann ${ }^{1}$ is an eloquent advocate of the manifest action of intelligence in nature, and of what may thus be called an 'intellectual' as opposed to a 'mechanical' conception of the universe. He lays much stress upon instinct, and is as earnest in asserting its distinct existence and nature as are the mechanicians in denying its existence.

As was said at the beginning of the former article, the great interest just now of the study of instinct, lies in its bearings on the Darwinian hypothesis, or rather on the philosophy therewith connected. Let us then proceed to examine whether or not the analogies before pointed out between instinct and other forms of vital activity can be carried further. Let us especially examine whether the consideration of instinct, in the widest sense of that term, throws any glimmerings of light upon that most recondite and still most mysterious process, the genesis of new species.

We may be encouraged to hope that such a result is possible from the words of one of those twin biologists who on the same night put forth their independently-arrived-at

${ }^{1}$ In his work on The Unconscious, a translation of which has been lately published by Messrs. Trübner \& Co. 
views as to what we are all agreed to regard as at least an important factor in the origin of species. No less a person than Mr. Wallace has written the following significant words :-

'No thoughtful person can contemplate without amazement the phenomena presented by the development of animals. We see the most diverse forms - a mollusk, a frog, and a mammal-arising from apparently identical primitive cells, and progressing for a time by very similar initial changes, but thereafter each pursuing its highly complex and often circuitous course of development with unerring certainty, by means of laws and forces of which we are totally igmorant. It is surely a not improbable supposition that the unknown power which determines and regulates this marvellous process may also determine the initiation of these more important changes of structure, and those developments of new parts and organs which characterise the successive stages of the evolutions of animal forms.'

These words advocate and confirm what I have elsewhere antecedently urged. Many influences doubtless may come into play in the origin of new species; but let us look a little narrowly at certain influences which must come into play therein, and the action of which no man can deny.

One of these influences (which no one has more richly illustrated than has the late Mr. Darwin) is that of heredity; but what is heredity?

In the first place it is obviously a property, not of new individuals, not of offspring, but of parental forms. As every one knows, it is the innate tendency which each organism possesses to reproduce its like. If any living creature, $x$, was self-impregnating and the outcome of a long line of self-impregnating predecessors, all existing in the midst of one uniform and continuously unvarying environment, then $x$ would produce offspring completely like itself. This fundamental biological law of reproduction may be compared with the physical first law of motion, according 
to which any body in motion will continue to move on uniformly at the same rate and in the same direction until some other force or motion is impressed upon it.

The fact that new individual organisms arise from both a paternal and a maternal influence, and from a line of ancestors every one of which had a similar bifold origin, modifies this first law of heredity only so far as to produce a more or less complex compound of hereditary reproductive tendencies in every individual, the effect of which must be analogous to that mechanical law of the composition of forces resulting in the production of a new creature resembling its immediate and more remote progenitors in varying degrees, according to (1) the amount of force springing from each ancestral strain, and (2) the compatibility or incompatibility ${ }^{1}$ of the prevailing tendencies, resulting in an intensification, perpetuation, modification, or neutralisation of ancestral characters, as the case may be.

All such action is but 'heredity' acting in one or other mode; but there is another and fundamentally different action which has to be considered, and that is the action of the environment upon nascent organisms-an action exercised either directly upon them, or indirectly upon them through its direct action upon their parents. That such actions produce unmistakable effects is notorious. It will be, I think, sufficient here to advert to such cases as the well-known brood-mare covered by a quagga, and the peculiar effects of a well-bred bitch being lined by a mongrel. These show how an action exercised upon the female parent (but with no direct action on the immediate offspring) may act indirectly upon her subsequent progeny.

As a rule, modifications accidentally or artificially induced in parents are not transmitted to their offspring, as is well

$1 \mathrm{Mr}$ Darwin tells us that two topknotted canaries produce bald offspring, due probably to some conflicting actions analogous to the interference of light. 
shown by the need of the repetition of circumcision, and of pressure of Indian children's heads and Chinese girls' feet, in each generation. Yet there is good evidence that such changes are occasionally inherited. The epileptic offspring of injured guinea-pigs is a case often referred to. Haeckel speaks of a bull which had lost its tail by accident, and which begot entirely tailless calves. With respect to cats, ${ }^{1}$ I am indebted to Mr. John Birkett for the knowledge of an instance in which a female with an injured tail produced some stump-tailed kittens in two litters.

There is evidence that certain variations are more apt to be inherited than others. Amongst those very apt to be inherited are skin affections, affections of the nervous system and of the generative organs, e.g. hypospadias and absence of the uterus. The last case is one especially interesting, because it can only be propagated indirectly.

Changes in the environment notoriously produce changes in certain cases, even in adults. The modifications which may result from the action of unusual agencies on the embryo have been well shown by M. C. Dareste. ${ }^{2}$ As has been already remarked, processes of repair take place the more readily the younger the age of the subject. Similarly, it is probable that the action of the environment generally acts more promptly and intensely on the embryo than in the older young. That the same organism will sometimes assume very different forms has been observed by Professor Lankester in the case of Bacterium rufescens. ${ }^{3}$

The effects of changed conditions is often very striking.

1 See The Cat (John Murray, 1881), p. 7.

2 See Archives de Zool. Expér. vol. ii. p. 414, vol. v. p. 174, vol. vi. p. 31 ; also Ann. des Sci. Nat. No. 4 série, Zoologie, vol. iii. p. 119, vol. xv. p. 1, vol. xvii. p. 243 ; and his work Recherches sur la Production artificielle des Monstruosités ou Essais de Tératogénie expérimentale.

${ }^{3}$ See Quarterly Journal of Micros. Soc., New Series (1873), vol. xiii. p. 408, and vol. xvi. (1876) p. 27. 
Ficus stipulata grown on a wall has small thin leaves, and clings to the surface like a large moss or a miniature ivy. Planted out, it forms a shrub, with large, coarse, leathery leaves.

Mr. Wallace has pointed out some of the curious direct effects of external conditions on organisms. He tells us ${ }^{1}$ that in the small island of Amboina the butterflies (twelve species, of nine different genera) are larger than those of any of the more considerable islands about it, and that this is an effect probably due to some local influence. In Celebes a whole series of butterflies are not only of a larger size, but have the same peculiar form of wing. The Duke of York's Island seems, he tells us, to have a tendency to make birds and insects white, or at least pale, and the Philippines to develop metallic colours; while the Moluccas and New Guinea seem to favour blackness and redness in parrots and pigeons. Species of butterflies which in India are provided with a tail to the wing begin to lose that appendage in the islands, and retain no trace of it on the borders of the Pacific. The Eneas group of papilios never have tails in the equatorial region of the Amazon Valley, but gradually acquire tails, in many cases, as they range towards the northern and southern tropics. Mr. Gould says that birds are more highly coloured under a clear atmosphere than in islands or on coasts-a condition which also seems to affect insects, while it is notorious that many shore plants have fleshy leaves. We need but refer to the English oysters mentioned by Costa, which, when transported to the Mediterranean, grew rapidly like the true Mediterranean oyster, and to the twenty different kinds of American trees said by Mr. Meehan to differ in the same manner from their nearest American allies, as well as to the dogs, cats, and rabbits which have been proved to undergo modifications directly induced by

1 Tropical Nature, pp. 254-259. Before quoted; see ante, p. 202. 
climatic change. But still more strange and striking changes have been recorded as due to external conditions. Thus it is said $^{1}$ that certain branchiopodous creatures of the crab and lobster class (certain crustacea) have been changed from the form characteristic of one genus (Artemia salina) into that of quite another (Branchipus), by having been introduced in large numbers by accident into very salt water. The latter form is not only larger than the former, but has an additional abdominal segment and a differently formed tail. Such changes tell strongly in favour of the existence in creatures of positive, innate tendencies to change in definite directions under special conditions.

It is also obvious that the very same influences (e.g. amounts of light, heat, moisture, etc.) will produce different effects in different species, as also that the nature of some species is more stubborn and less prone to variation than that of others. Such, for example, is the case with the ass, the guinea-fowl, and the goose, as compared with the dog, the horse, the domestic fowl, and the pigeon. Thus both the amount and the kind of variability differ in different races, and such constitutional capacities or incapacities tend to be inherited by their derivative forms, and so every kind of animal must have its own inherent powers of modifiability or resistance, so that no organism or race of organisms can vary in an absolutely indefinite manner; and if so, then unlimited variability must be a thing absolutely impossible.

The foregoing considerations tend to show that every variation is a function ${ }^{2}$ of ' heredity' and 'external influence' -i.e. is the result of the reaction of the special nature of each organism upon the stimuli of its environment.

I Nature, 1876, June 8, p. 133. Schmankevitsch at Odessa.

2 In the mathematical sense of the word. 
In addition to the action of heredity and the action of the environment, there is also a peculiar kind of action due to an internal force which has brought about so many interesting cases of what is called 'serial and lateral homology' which cannot be due to descent, but which demonstrate the existence of an intra-organic activity, the laws of which have yet to be investigated. Comparative anatomy, pathology, and teratology combine to point out the action of this internal force.

'Lateral homology' refers to the production of similar structures on either side of the body, as in the similarity of our right and left hands and feet. 'Serial homology' refers to the production of similar structures one behind the other, as in the series of similar segments in the body of a worm or a centipede, and the similar series of limbs in the latter animal.

These tendencies to lateral and serial repetition show themselves in ways which cannot be accounted for by inheritance from ancestral forms, but loudly proclaim the presence and action of some internal force tending to produce such homologous repetitions in organisms in different animals.

Thus even in ourselves, when we compare our leg and foot with our arm and hand, we find that they have homologous features which cannot be accounted for as being inheritances from supposed ancestral animals. Our extremities resemble each other in the texture of the skin, the shape of the nails, and other points, and these resemblances are not due to external conditions, but exist in spite of them; and comparative anatomy reveals to us countless similar examples in the animal kingdom. Limbs can hardly be more unlike in form and position than are the arms and legs of birds, and yet we meet with breeds of fowls and pigeons the feet of which are furnished with what are called 'boots,' that is, with long feathers which grow 
on the side of the foot, serially corresponding with that of the hand, which grow the feathers of the wing.

Again, in disease, and in cases of monstrosity or congenital malformation, nothing is more common than to find precisely similarly diseased conditions, or similar abnormalities of structure, affecting serially or laterally homologous parts, such as corresponding parts of the two arms or two legs, or of the right (or left) arm and hand and leg and foot respectively.

Altogether it seems then to be undeniable that the characters and the variations of species $^{1}$ are due to the combined action of internal and external agencies acting in a direct, positive, and constructive manner.

It is obvious, however, that no character very prejudicial to a species could ever be established, owing to the perpetual action of all the destructive forces of nature, which destructive forces, considered as one whole, have been personified under the name 'natural selection.'

Its action, of course, is, and must be, destructive and negative. The evolution of a new species is as necessarily a process which is constructive and positive, and, as all must admit, is one due to those variations upon which natural selection acts. Variation, which thus lies at the origin of every new species, is (as we have seen) the reaction of the nature of the varying animal upon all the multitudinous agencies which environ it. Thus 'the nature of the animal' must be taken as the cause, 'the environment' being the stimulus which sets that cause in action, and 'natural selection' the agency which restrains it within the bounds of physiological propriety.

1 The existence of internal force must be allowed. We cannot conceive of a universe consisting of atoms acted on indeed by external forces, but having no internal power of response to such actions. Even in such conceptions as those of 'physiological units' and 'gemmules' we have (as the late Mr. G. H. Lewes remarked) given as an explanation that very power the existence of which in larger organisms had itself to be explained. 


\section{Organic Nature's Riddle}

We may compare the production of a new species to the production of a statue. We have (1) the marble material responding to the matter of the organism; (2) the intelligent active force of the sculptor, directing his arm, responding to the psychic nature of the organism, which reacts according to law as surely as in the case of reflex action in healing, or in any other vital action; (3) the various conceptions of the artist, which stimulate him to model, responding to the environing agencies which evoke variation; and (4) the blows of the smiting chisel, corresponding to the action of natural selection. No one would call the mere blows of the chisel-apart from both the active force of the artist and the ideal conceptions which direct that force-the cause of the production of the statue: They are a cause-they help to produce it, and are absolutely necessary for its production. They are a material cause, but not the primary cause. This distinction runs through all spheres of activity. Thus the inadequacy of 'natural selection' to explain the origin of species runs parallel with its inadequacy to explain the origin of instinct, as before pointed out.

The formal discoverer of a new fossil is the naturalist who first sees it with an instructed eye, appreciates and describes it, not the labourer who accidentally uncovers but ignores it, and who cannot be accounted to be, any more than the spade he handles, other than a mere material cause of its discovery. So we must regard the sum of the destructive agencies of nature as a material cause of the origin of new species, their formal cause being the reaction of the nature of their parent organisms upon the sum of the multitudinous influences of their environment. This kind of action of 'the organism' - this formal cause-has been compared by Mr. Alfred Wallace, and by me, with the action of the organism in its embryonic development; and 
this, I have further urged, is to be likened to the processes of repair and reproduction of parts of the individual after injury, and this, again, to reflex action, and, finally, this last to instinct as manifested in ourselves and in other animals also.

The phenomena, then, exhibited in the various processes which have been passed in review-nutrition, growth, repair, reflex action, instinct, the evolution of the individual and of the species-will, I think, abundantly serve to convince him who carefully considers them, that a mechanical conception of nature is inadequate and untenable. For it cannot be denied that in all these various natural processes, performed by creatures devoid of self-conscious intellect, there is somehow and somewhere a latent rationality, by the imminent existence of which their various admirably calculated activities are alone explicable. We are compelled to admit that the merely animal and vegetal worlds, which we regard as irrational, possess a certain rationality. This innate mysterious rationality blindly executes the most elaborately contrived actions in order to effect necessary or useful ends not consciously in view. We have here to consider the question, 'How is this blind rationality, this practical but unconscious intelligence, explicable?'

Edward Von Hartmann, the eloquent prophet of the unconscious intelligence of nature, teaches us that such intelligence is the attribute of the very animals and plants themselves.

But can we limit the manifestations of intelligence and quasi-instinctive purpose to the organic world? By no means. The phenomena of crystallisation, the repair in due form of the broken angle of a crystal, the inherent tendencies of chemical substances to combine in definite proportions, and other laws of the inorganic world, speak to us of unconscious intelligence and volition latent in it also. 
A perception of this truth has led to the conception of the universal presence of true intelligence, as it were in a rudimentary form, throughout the whole material universe -the universal diffusion of what the late Professor Clifford called 'mind-stuff' in every particle of matter.

Such a belief can, however, be entertained only by those who neglect to note the differences of objects presented to the senses, attending solely to their resemblances, and describing them by inadequate and misleading terms. The habit of perverting language in this manner has been lately well spoken of as using intellectual false coin. By such an abuse of language and disregard of points of unlikeness, all diversities may easily be reduced to identity. Against such abuse the scientific biologist must energetically protest. The expression 'life' refers to definite phenomena which are not found but in animals and plants. The crystal is not really alive, because it does not undergo the cycle of changes characteristic of life. It does not sustain itself by alimentation, reproduce its kind, and die. Any one choosing to stretch terms may say that molecules of inorganic matter live, because molecules exist. But in that case we shall have to create a new term to denote what we now call life. We might as well say a lamp-post 'feels' because we can make an impression on it, or that crystals 'calculate' because of their geometrical proportions, or that oxygen 'lusts' after that which it rusts. As the late Mr. G. H. Lewes has said :-

'We deny that a crystal has sensibility; we deny it on the ground that crystals exhibit no more signs of sensibility than plants exhibit signs of civilisation, and we deny it on the ground that among the conditions of sensibility there are some positively known to us, and these are demonstrably absent from the crystal. We have full evidence that it is only special kinds of molecular change that exhibit the special signs called sentient; we have as good evidence 
that only special aggregations of molecules are vital, and that sensibility never appears except in a living organism, disappearing with the vital activities, as we know that banks and trades-unions are specifically human institutions.'

The considerations which are here applied to vital activity may be paralleled by others applied to intelligence. They will show us that however profoundly rational may be that world which is commonly spoken of as irrational, yet that its rationality is not really the attribute of the various animals which perform such admirably calculated actions, but truly belongs to what is the ultimate and common cause of them all, and to that only.

There is, indeed, a logic in mere 'feeling,' there is a logic even in insentient nature; but that logic is not the logic of the crystal nor of the brute; its true position must be sought elsewhere. It is in them, but it is not of them.

However, let us patiently consider a little this hypothesis of an innate, unconscious intelligence as the cause of the various strictly, or analogically, instinctive actions of animals.

It is in the first place plain that no intelligence could exist so as to adjust 'means' to 'ends,' except by the aid of memory; and 'memory' has therefore been freely attributed even to the lower animals. Let us see, then, what the term 'memory' really denotes. Now we cannot be said to remember anything unless we are conscious that what is again made present to our mind has been present to our mind before. An image might recur to our imagination a hundred times, but if at each recurrence it was for us something altogether new and unconnected with the past, we could not be said to remember it. It would rather be an example of extreme 'forgetfulness' than of 'memory.' In 'memory,' then, there are and must be two distinct elements. The first is the reproduction before the mind of what has been before the mind previously, and the 
second element is the recognition of what is so reproduced as being connected with the past.

There is yet a further distinction which may be drawn between acts of true recollection.

We are all aware that every now and then we direct our attention to try and recall something which we know we have for the moment forgotten, and which we instantly recognise when we have recalled it. But besides this voluntary memory we are sometimes startled by the flashing into consciousness of something we had forgotten, and which we were so far from trying to recollect that we were thinking of something entirely different.

There are, then, two kinds of true memory-one in which the will intervenes, and which may be spoken of as recollection, and the other in which it does not, and which may be termed reminiscence. ${ }^{1}$ Neither of these can exist in a creature destitute of true self-consciousness. There are, however, two other kinds of repeated action which take place even in ourselves, and which should be carefully distinguished.

The first of these are practically automatic actions, which are repeated unconsciously after having been learned, as in walking, reading, speaking, and often in playing some musical instrument. In a certain vague and improper sense we may be said-having learned how to do these things-to recollect how to do them; but unless the mind recognises the past in the present while performing them they are not instances of memory, but merely a form of habit in which consciousness may or may not intervene.

The second class of repeated actions just referred to are, on the other hand, those in which consciousness cannot be made to intervene, and are mere acts of organic habit. Thus a man wrecked on an island inhabited by savages, and long dwelling there, may at first have the due action of his

I See ante, p. 209. 
digestive organs impeded by the unwonted food on which he may have to live. After a little while, however, the evil diminishes, and in time his organism may have 'learnt' how to correspond perfectly with the new conditions. Then with each fresh meal the alimentary canal and glands must practically 'recognise' a return of the recently obtained experience, and repeat its freshly acquired power of healthy response thereto. Can 'memory' be properly predicated of such actions of the alimentary glands? It can be so predicated only by a perversion of language. It is not memory, because not only is it divorced from consciousness as it occurs, but it cannot anyhow be made present to consciousness. Again, a boy at school has had a kick at football, which has left a deep scar on his leg. That boy, now become an old man, still bears the same scar, though all his tissues have been again and again transformed in the course of seventy years. Can the constant reproduction of the mark, in any reasonable sense, be said to be an act of, or due to, memory? Evidently it cannot, and neither can it be reasonably predicated of any of the actions of plants or of the lowest animals.

As, then, 'memory' cannot be predicated, except by an abuse of language, of the lower forms of life, it would appear that neither intelligence nor rationality can truly exist in them, so as to preside over all those actions of nutrition, repair, reproduction, and instinct which we have examined and distinguished.

Nevertheless, Hartmann and his followers do not on this account hesitate to ascribe true intelligence to unconscious nature, and though such ascription may seem too absurd to deserve serious consideration, it would nevertheless be a great mistake to despise such opinions. For, as Mr. Lewes truly says, ' 'As there are many truths which

1 Problems of Life and Mind, ii. iii. iv. of Third Series, p. 85. 
cease to be appreciated because they are never disputed,' so there are many errors which are best exposed by allowing them to run to a head. Mr. Butler, who carries this hypothesis of unconscious intelligence to its last consequences, asks, ${ }^{1}$ 'What is to know how to do a thing?' His answer is, 'Surely, to do it.' And he represents how, when many things have been perfectly learnt, they may be performed unconsciously. In a very amusing chapter on 'Conscious and Unconscious Knowers,' he says, 'Whenever we find people knowing they know this or that... they do not yet know it perfectly.' In another place he says, ${ }^{2}$ 'We say of the chicken that it knows how to run about as soon as it is hatched . . . but had it no knowledge before it was hatched? It grew eyes, feathers, and bones; yet we say it knew nothing about all this. ... What, then, does it know? Whatever it knows so well as to be unconscious of knowing it. Knowledge dwells on the confines of uncertainty. When we are very certain we do not know that we know. When we will very strongly, we do not know that we will.'

Now the fact is that there is great ambiguity in the use of the word know. Just as before with the term memory, so also here, certain distinctions must be drawn if we would think coherently.

$A$. To ' know,' in the highest sense which we give to the word, is to be aware (by a reflex act) that we really have a certain given perception. It is a voluntary, intelligent, self-conscious act, parallel to that kind of memory which we before distinguished as ' recollection.'

$B$. We also say we 'know' when we do not use a reflex act, but yet have a true perception-a perception accompanied by consciousness-as when we teach, and in most of our ordinary intellectual acts.

1 Life and Habit, p. 55.

2 Unconscious Memory, p. 30.

VOL. II. 
C. When we so 'know' a thing that it can be done with perfect unconsciousness, we cannot be said to 'know' it intellectually, although in doing that thing our nervous and motor mechanism acts (in response to sensational stimuli) as perfectly as, or more perfectly than, in our conscious activity. The 'knowledge' which accompanies such 'unconscious action' is improperly so called, except in so far as we may be able to direct our minds to its perception, and so render it worthy of the name-as we have seen we may direct attention to our unconscious reminiscences, and so make them conscious ones. In the same way then in which we have already distinguished such acts of memory (while unconscious) as sensuous memory, so we may distinguish such acts of apprehension (while unconscious) as sensuous cognition. By it we can understand, to a certain extent, what may be the 'knowledge' or 'sensuous cognition' of mere animals.

$D$. Besides the above three kinds of apprehensions, we may distinguish others which can be only very remotely, if at all, compared with knowledge, since they can never, by any effort, be brought within the sphere of consciousness. Such are the actions of our organism by which it responds to impressions in an orderly and appropriate but unfelt manner-the intimate actions of our visceral organs, which can be modified, within limits, according to the influence brought to bear on them, as we may see in the oarsman's hand, the blacksmith's arm, and the balletdancer's leg.

If such actions could be spoken of as in any sense apprehensive, they would have to be spoken of as 'organic cognitions,' but they may be best distinguished as 'organic response' or 'organic correspondence.'

That the inorganic world, no less than the organic, is instinct with reason, and that we find in it objective con- 


\section{Organic Nature's Riddle}

ditions which correspond with our subjective conceptions, is perfectly true; but when once the profound difference between mere organic habit and intellectual memory is apprehended, there will be little difficulty in recognising the yet greater difference between 'organic correspondence' and the faithfulness of inorganic matter to the laws of its being.

That the absence of consciousness in actions which are perfectly performed does not make such actions into acts of ' perfect knowledge' is demonstrated by every calculating machine. ${ }^{1}$ No sane person can say that such a machine 'possesses' knowledge, though it is true that it 'exhibits' it. Similarly we must refuse to apply the terms 'memory' and 'intelligence' to the merely organic activity of animals and plants.

The assertion that in the vegetal and lowest animal forms of life there is an innate but unconscious intelligence, is an assertion which contains an inherent contradiction, and is therefore fundamentally irrational. Any one who says that blind actions (in which no end is perceived or intended) are truly intelligent ones, abuses language. The meaning of words is due to convention, and any one who calls such actions truly intelligent divides himself from the rest of mankind by refusing to speak their language.

What experience have we which can justify such a conception as that of 'unconscious intelligence'? We are indeed aware of a multitude of actions which are evidently the outcome of intelligence, but which (like the analogous action of a calculating machine) are performed by creatures really unconscious, though they may possess consentience. But consciousness is the accompaniment of all those actions which we know to be intellectual and rational. Our experience then contradicts the hypothesis of the existence of any such thing as 'unconscious intelligence.' Such a thing is

1 See ante, p. 98. 
indeed no true concept, for it is incapable not only of being imagined but also of being really conceived of. It resembles such unmeaning expressions as 'a square pentagon' or a ' pitch-dark luminosity.'

Nevertheless, our experience is in favour of the existence of an intelligence which can implant in and elicit from unconscious bodies activities which are intelligent in appearance and result. Thus we can construct calculating machines and train animals to perform many actions which have a delusive semblance of rationality.

'Truly intelligent action' we know as being intelligent and rational in its foresight, and therefore as necessarily conscious in the very principle of its being.

' Unconsciously intelligent action,' improperly called 'intelligent' or 'wise,' is that which is intelligent and wise only as to its results, and not in the innermost principle of the creatures (whether living or mere machines) which perform such action. To speak technically, we have 'formal' and 'material' intelligence, ${ }^{1}$ as we have 'formal' and 'material ' vice and virtue. ${ }^{2}$ We have already distinguished between the 'formal' and the merely 'material' discoverer of a new fossil, and this distinction is one which it is most important to bear in mind. It is the failure to apprehend this distinction which is the root of a vast number of modern philosophical errors, and the error which consists in asserting the reality of ' unconscious intelligence' is one of them.

In fact 'intelligence' exists very truly, in a certain sense, in the admirably directed actions blindly performed by living beings. It is not, however, 'formally' in them, but

1 See also ante, vol. i. p. 328.

2 Thus a man wishing to aid another, but who by miscalculation causes his death, does an action which is ' materially' homicidal, though 'formally' his action is a virtuous one. Similarly a man may be ' materially' a bigamist but not 'formally,' as when he has married a second wife being honestly convinced that his first wife was dead. 
exists formally in their ultimate cause. Nevertheless that intelligence is so implanted within them that it truly exists in them ' materially' though it is not ' formally' in them.

We have here, then, the answer to the question, 'What is the rationality of the irrational?' It is a rationality which is very really, though but materially, present in the irrational world, while it is formally present in that world's cause and origin.

To every Theist this answer will be a satisfactory one. To him who is not a Theist there is no really satisfactory answer possible. This is a question not of theology but of pure reason antecedent to all theology. To reason, and to reason only, I appeal when I affirm that the existence of a constant, pervading, sustaining, directing, and all-controlling but unfathomable intelligence which is not the intelligence of irrational creatures themselves, is the supreme truth which nature eloquently proclaims to him who with unprejudiced reason and loving sympathy will carefully consider her ways. He can hardly fail to discover, immanent in the material universe, ' an action the results of which harmonises with man's reason; an action which is orderly, and disaccords with blind chance, or " a fortuitous concurrence of atoms," but which ever eludes his grasp, and which acts in modes different from those by which we should attempt to accomplish similar ends.' ${ }^{1}$ For myself, I am bound humbly to confess that the more I study nature the more I am convinced that in the action of this all-pervading but inscrutable and unimaginable intelligence, of which selfconscious human rationality is the utterly inadequate image, though the only image attainable by us, is to be sought the sole possible explanation of the mysterious but undeniable presence in nature of a rationality in that which is in itself irrational.

1 Lessons from Nature, ch. xii. p. 374. John Murray, 1876. 


\section{WHAT ARE ANIMALS AND PLANTS?}

THIS question: 'What are animals and plants?' is a 1 large question. In order to be able to reply to it, we must know both (1) what animals and plants are, as contrasted with substances which are neither the one nor the other; and (2) how animals and plants stand towards each other-their relations and their differences. Only by learning these two things can we possibly know what animals and plants are.

The common-sense, however, of the overwhelming majority of men will make short work of the first question; they will say: 'Animals and plants are living things, while all other visible substances are but composed of dead matter.' Now, we have no quarrel with common-sense, we fully accept its dictates; but the patient and admirable researches of generations of men of science, and the speculations of modern philosophers, have made known so many curious phenomena, and have brought forward so many objections, that it is no longer possible for him who would be able to give an account of the belief that is in him concerning the world and its inhabitants, to rest satisfied with such a rough-and-ready reply.

Similarly, with regard to the second question-the relations between animals and plants-most men would, perhaps, reply that 'animals are living creatures, which move about, and get their living by the help of their senses, while plants 
are living creatures devoid of sense and, for the most part, rooted to the ground.'

Now, this is really a very good answer, as far as it goes, and truly expresses the distinction existing between the immense majority of the two groups of living things. Nevertheless, here again the discovery of fresh phenomena has brought us face to face with difficulties and puzzles, some of which seem, as yet, insoluble.

To put as shortly as possible what appears to be the outcome of modern scientific progress, it has, on the one hand, served to render more marked the distinction between living beings and creatures devoid of life; while, on the other hand, it has continually made more and more evident that (in spite of the distinctions between most of them) animals and plants form one great whole, and must be scientifically treated together, as well as separately.

Thus, to the two sciences of zoology and botany, which refer to animals and plants respectively, we have now added a fresh science, the science of BIoLOGY, which treats of animals and plants taken together, collectively, as forming one great group.

That the reader may have some faint notion how vast this great group is, it may be well hastily to survey the main classes of creatures which together compose it. We think it desirable to do so, because very inadequate images are apt to rise before the minds of most persons unacquainted with natural science, when they use such words as 'animals' and 'plants,' since they naturally think most of those with which they are the most familiar.

Thus, they are familiar with certain beasts, birds, reptiles, and fishes, but know little about the number of them. Of birds, ten thousand distinct kinds are known, and upwards of four thousand kinds of lizards, and sixteen hundred kinds of snakes have been described; while fishes are so rich in 
species that they probably equal in the number of their kinds the whole mass of beasts, birds, and reptiles taken together !

But such creatures as these form but a very small proportion of all animals. Creatures such as snails and oysters form another vast group, known as 'mollusks.'

Worms, also, have been formed into a division, so varied in nature and so prodigious in number that their proper classification is amongst the most difficult of zoological problems.

The star-fishes and their allies constitute another great group, rich both in species and diversities of form.

But the whole of the creatures we have yet referred to, taken together in one mass, are far exceeded in the number of their distinct species by the class of insects alone (of which one or more are associated with the life of each and every land plant, and probably that of every higher animal also); while closely allied to insects are the multitudinous tribes of lobsters, shrimps, crabs, spiders, and scorpions.

We have also to take into account those coral animals which have actually built up large tracts of the earth's habitable surface; and besides these, we have their humble followers, the sponges.

All the creatures yet referred to are cognisable by our ordinary senses; but there are, as is commonly known, myriads of kinds, either so small as to be altogether invisible to the naked eye, or else invisible as regards the main points of their structure without the aid of the microscope. All the lowest animals, the bodies of which are not made up of distinct organic substances, or tissues, are called ProtozoA.

Then, as to plants: besides the families of flowering trees, shrubs, creepers, and herbs, with members of which we unconsciously become more or less familiar, there are a multitude of other families, specimens of which we only see in our 
occasional visits to the hot-houses of our botanical gardens. To these follow the almost numberless kinds of plants which do not flower-the ferns, horse-tails, grasses, lichens, seaweeds (with their fresh-water allies), and fungi. Parallel with the microscopic creatures ordinarily classed as 'animals' are the microscopic plants, some of which have been, till of late years, the despair of the surgeon; while others are now recognised as, or suspected to be, the cause and origin of the most painful and dangerous diseases.

Multitudinous, however, as is the animal and vegetable life which we have about us to-day, it is but a remnant of that of which this planet has been the theatre; and especially wonderful are the discoveries of fossil remains which have been made in North America, revealing to us the past existence of living forms such as had not been pictured even in the recorded musings of any naturalist. Apart from such wonderful scientific novelties, we have in the ancient chalk cliffs, and the far more ancient coal-fields, abundant evidence of the prodigality and duration of past vitality. The chalk is, as it were, still in process of formation, as the ooze slowly forming in the bed of the Atlantic Ocean. The coal affords evidence that rich vegetable life flourished at a period so remote that during it the first appearance of the chalk might have seemed as the dream of an infinitely distant future.

It is this immensely complex mass of living beings which we have to regard, in their totality, as one whole, as well as in their two component groups, if we would know what 'animals' and 'plants' really are.

But in order that we may learn what they are, it will be well first to advert briefly to one or two facts concerning things which are neither plants nor animals, certain facts, that is, about the 'inorganic world,' by which we mean the solid earth with its two envelopes-water and air. All the substances of which this inorganic world is composed are 
either (1) elements, such e.g. as the gas oxygen or the metal iron; or (2) compounds of elements, such, e.g., as rust, which consists of oxygen and iron united to form a third substance which is neither the one nor the other.

Very many substances can exist (as water can) in three states, solid (ice), fluid (water), aëriform (vapour).

A solid inorganic substance may be either in the form of crystal (as marble) or not crystalline (as chalk), while having all the time the same chemical composition. Thus both marble and chalk can be resolved into (1) lime and (2) a gas, commonly known as carbonic acid gas, and carbonic acid is again resolvable into (1) oxygen and (2) carbon, or pure charcoal.

The aëriform envelope of this planet-that is, AIR-is a mixture of the two gases (1) oxygen and (2) nitrogen, with some carbonic acid gas and a certain amount of ammonia and the vapour of water.

Oxygen, itself incombustible, is the great burner or aider of combustion.

Nitrogen is remarkable at once both for its own inertness and for its instability; so that it is an ingredient in all the most explosive compounds, such as gunpowder, guncotton, nitroglycerine and the iodide, sulphide, and chloride of nitrogen.

Of carbonic acid there are ordinarily but four cubic feet in ten thousand cubic feet of air; yet so great is the quantity of it contained in the whole atmosphere that there are reckoned to be 371,475 tons of it in the column of atmosphere which extends above each square mile of the earth's surface.

WATER, the earth's fluid envelope, consists of oxygen, hydrogen, carbonic acid, ammonia, carbonate of lime, flint (in solution), and sundry salts. It is, as it were, the mother substance of life, both historically and physiologically, and has been a great agent in both the production and the destruction 
of fossil remains : the first, by its deposits; the second, by its croding agency. The Mississippi has formed thirty thousand square miles of deposits, which are in places several hundred feet thick. The Ganges carries down yearly to the sea as much mud as could be carried down by 730,000 ships, each of 1400 tons burthen. The eroding and destructive agency of water is, on the other hand, notorious.

Having acquired these preliminary notions concerning the inorganic or non-living world, we may next review such contrasts as may be drawn between it and the living world of animals and plants considered as one whole.

I. Now, in the first place, some inorganic substances are fluid and some solid, some moist and some dry; but every living creature, without exception, is more or less fluid, and composed to a greater or less degree of water, especially its more actively vital or growing parts.

Thus, in the human brain, seventy out of every hundred parts are composed of water, and in the jelly-fish no less than ninety-nine parts out of a hundred are so composed.

II. Many inorganic substance, such as crystals, are bounded by flat surfaces and straight lines, but living creatures have bodies which are bounded by curved surfaces and lines.

III. The chemical composition of inorganic substances is most various; some, like gold, consist of but a single element; others, like water, of two elements; others of several and very different ones.

All living bodies, on the other hand, are of very uniform chemical composition, as they invariably consist of oxygen, hydrogen, and carbon, together with the element nitrogenthe unstable nature of which has already been referred to in speaking of the inorganic compounds containing nitrogen, which thus seems a fitting element to enter into the composition of anything so prone to change as is living matter. 
IV. In every animal and plant these four elements (oxygen, hydrogen, carbon, and nitrogen) unite to form a special substance known as protoplasm, of which every living organism is at first entirely composed, while the whole inorganic world is destitute of such material.

This curious substance, while living, has six very remarkable powers :-

(1.) A power of internal circulation, or of the movement of various parts of its substance within the whole, unlike anything in the inorganic world.

(2.) A power of contraction and expansion under conditions different from those which contract and expand inorganic substances.

(3.) A power of performing chemical changes and evolving heat more gently and continuously than in the combustion of inorganic bodies.

(4.) A power of converting other adjacent substances into material like itself - into its own substance.

(5.) A power of forming from its own substance substances both different from its own and from substances adjacent to it. Thus it is that since every living creature consists at first entirely of protoplasm, every other kind of substance found in every animal or plant comes from protoplasm and is formed by its agency.

(6.) A power of exchanging gases with its environmentnotably of absorbing oxygen and giving out carbonic acid.

These exclusively vital powers of living particles of protoplasm give to each whole organism of which they form a part certain further characters by which they all differ from the inorganic world. Thus :-

V. Every living creature, whether plant or animal, affects that interchange of gases just mentioned (absorbing oxygen and giving out carbonic acid), that is to say, it respires or breathes-whatever other changes it may affect. 
VI. Every living being is a creature requiring food, which it has the power of changing into its own substance, and so, at least for a time, augmenting its size by a process of growth. This growth is not a mere external increment, like the growth of a crystal suspended in a suitable medium, but is an augmentation of its intimate innermost substance by what is called intussusception.

VII. Every living creature thus grows according to a more or less definite law, from a single, minute, spheroidal mass of protoplasm into that shape and structure which is characteristic of the group to which it belongs.

VIII. In this process each such creature forms certain substances which are not protoplasm,--at the very least it forms minute granules which may be fatty or starchy; while, as a general rule, living creatures do form the most complex structures, namely, all those found in the animal and vegetable kingdoms - the woods, resins, oils, and sugars of plants, and all the varied components of the bodies of animals; this process is known as 'secretion.'

By this latter process the living world, as one whole, is continually taking matter from the earth's aërial and aqueous envelopes and adding it to the substance of the earth's solid crust. The past effect of this action we see, as before mentioned, in the enormous fields of coal and peat; in the extensive chalk formations and coral reefs (one reef extending for a thousand miles along the coast of Australia, and such structures forming a great part of Florida); in the vast accumulations of fossil remains-evidenced by the fact that the fossil ear bones of whales (a valuable manure) have given rise to a lawsuit, and by the five million cubic feet of shellsand annually collected on the shores of Devon and Cornwall.

As to the present activity of the vegetable world in this direction, we have but to recollect that Brazil is mainly a forest region which may be roughly represented as an 
equilateral triangle, each side of which is twelve hundred miles long, and that other vast regions of the earth's surface are, like it, clothed not only with herbage, but with teeming vegetable produce of all kinds and dimensions.

Now, if we suppose two-thirds of the earth's dry land to be clothed with only such vegetation as may be estimated to produce an average increase of its substance, amounting to but one three hundred and sixty-fifth part of an inch daily, then we should have freshly formed each year as much vegetal matter as would constitute a cube fifteen miles in extent in each of such cube's three dimensions !

IX. But living creatures not only grow and develop their own bodies; they also reproduce their kind; and this is again an action to which there is nothing comparable or analogous in the whole inorganic world.

Thus every living being may be said to be a creature possessing an innate tendency to undergo a definite cycle of changes when exposed to certain fixed conditions; that is, when supplied with an adequate amount of temperature, moisture, suitable gaseous matter, food, etc. Inorganic and dead substances may tend to undergo a series of changes, but such series never constitutes a 'cycle'-i.e., a series returning to the point whence it set out. We see such a cycle of changes in the egg, the chick, the fowl, and the egg again; or the egg, the grub, the chrysalis, the butterfly, and ultimately its egg; or the seed, the young plant, the mature plant, the flower, the fruit, and the seed again.

Inorganic substances tend simply to persist as they are, and have no definite relations either to the past or to the future. Whence it comes, or what it has been or shall be, is nothing to its present being-which is its only being. But every living creature, at every step of its life, regards both the past and the future, and thus lives continually in a definite relation to both these as well as to the present. 
Every stage of its cycle of life, just because it is a cycle, is conditioned by the anterior states which alone have made it possible, and refers to future states for which it is in active preparation. Thus, as it were, at every present moment of its existence, it lives both in the past and in the future, a mode of existence which attains its fullest development in the highest living organism-man, the one creature emphatically, because consciously, 'looking before and after'!1

$\mathrm{X}$. But living creatures present another still more distinctive character, one which is indeed but obscurely indicated in plants, but is very evident in animals. This is the power of forming habits, which is itself the sign of the possession of a special internal spontaneity in living things, by which they each and all tend to act and to 'react' when acted upon.

For what is a 'habit'? A 'habit' is not formed by repeated actions, though it may be strengthened and confirmed by them. If an act performed once only had not in it some power of generating a 'habit,' then a thousand repetitions of that act would not generate it. ${ }^{2}$ Habit is the determination in one definite direction of a previously vague tendency to action. All living organisms tend to act. With them action is not only their nature, it is a positive want. Moreover, within limits, the powers and energies of living creatures increase with action, and diminish, and finally perish, through repose. Thus the general activity and power of organisms, and also the exercise of this power in definite modes and directions, are facilitated and increased by actions in the very first of which the power of 'generating habit' lies hid.

This second, mysterious, internal tendency, as we have said, eminently distinguishes living organisms from all inor-

${ }^{1}$ As we have before pointed out, see ante, p. 350.

2 See also ante, p. 327. 
ganic bodies, and leads naturally to the next point we would refer to.

Closely allied to habit is instinct, a power, the presence of which cannot indeed be adduced as a character distinguishing all living beings from bodies devoid of life, but which none the less is so remarkable a property of many animals that it may well claim, for our present purpose, to be here briefly referred to in passing.

We have no space here to describe at length examples of animal instinct; we can but very briefly refer to such wellknown instances as the simulated lameness of certain birds, the insects which become quiescent to escape an enemy (what is wrongly called shamming death), and provision for the future, as in the wasp sphex, the carpenter bee, and the stag beetle. Certain instincts, however, have a very peculiar significance; such are those by which a grub will repair its injured cocoon or a spider its injured web, and those by which lobsters and crabs, when one of their limbs is injured, will throw off the injured stump as far up as one of its joints, whence alone the limb can again grow forth and be reproduced. Such creatures cannot be supposed to know the effect of such spontaneous amputations, and therefore their actions lead us naturally to consider other unconscious organic actions by which lost parts are more or less perfectly reproduced-actions which display a purpose and intention (although unconscious) in a way which resembles nothing in the inorganic world.

In the process of healing and repair of a wounded part of our body we meet with wonderful phenomena. ${ }^{1}$ But repairs of injuries of a far more surprising kind are found amongst the lower animals, and repair in the vegetal world is so common that it ceases to excite our surprise. Such unconscious and purposive organic actions are allied to instinctive

${ }^{1}$ See ante, p. 335. 
action, using that term in a wide analogical sense. But truly instinctive actions take place IN Us at the dawn of life. It is by the aid of such alone that the infant lives. Instinctive also are many of the phenomena of adolescence and those of the earlier years of our own race-for no one can maintain that the first beginnings of literature, art, science, or politics were ever deliberately invented.

How, then, are we to regard that great world of living creatures, both the lower and the higher members of which present phenomena so different from anything to be found in the whole inorganic world? Are, or are not, the bodies of animals and plants vehicles for the exhibition of some force or energy radically different from any to be found in the nonliving world about them, or are all their actions to be regarded as only the very curious activities of very complex machines, moved by no other power than such as are inherent in the inanimate matters of this planet? Are we, in a word, to accept a merely mechanical explanation of the universe, or must we demand something more, and if so, what ?

To many of our readers it may seem altogether absurd to attempt to explain the phenomena of life in terms of the movements of solid particles. Their common-sense revolts at such an explanation, but 'common-sense' cannot be allowed by itself to decide any question when an appeal has once been made to the higher tribunal of pure reason, and such an appeal has been made.

For there can be no question but that a thoroughly mechanical conception of nature is the scientific ideal of a very large and a very influential school of thinkers, and is the goal towards which they strive-following the footsteps of their great predecessor Descartes. Thus, as we have elsewhere noted, ${ }^{1}$ Kirchhoff tells us that 'the highest object at which the natural sciences are constrained to aim is the

VOL. II. 
reduction of all the phenomena of nature to mechanics.' Helmholtz has declared that "the aim of the natural sciences is to resolve themselves into mechanics.' According to Wundt, 'the problem of physiology is a reduction of vital phenomena to general physical laws, and ultimately to the fundamental laws of mechanics'; and Haeckel tells us that 'all natural phenomena without exception, from the motions of the celestial bodies to the growth of plants and the consciousness of men ... are ultimately to be reduced to atomic mechanics.'

Many, if not most, of the scientific men of our day strongly favour a mechanical explanation of nature, and treat with disfavour, not to say contempt, the conception of a distinct kind of energy or a 'VITAL FORCE' - a conception which has been maintained by a school of physiologists called on that account 'vitalists.'

Now it is surely not to be supposed that this preference for 'mechanism' by so many distinguished men of science can be due to any mere prejudice on their part, or that there are not some good and substantial reasons why they should favour it, and yet it is hard to suppose that the commonsense of mankind, which has ever opposed the mechanical view, can be entirely due to a mere delusion either, and have no solid support from reason!

Let us first for a moment consider what is the aim and end of all physical science. Surely it is to understand the co-existences and successions of natural phenomena in such a way that they cannot only be arranged in convenient groups suitable for the limited powers of the human intellect to grasp, but also serve as a basis of scientific prediction-while the coming true of 'predictions' which men of science feel justified in making affords a strong ground for believing that the operations which served as a basis for such fulfilled predictions were themselves true. 
Thus, as regards the science of astronomy, who does not now see that our conceptions of the motions of the heavenly bodies have been greatly facilitated by the discovery of the law of gravitation? and who does not perceive in the verification of scientific prophecy, by the discovery of the planet Neptune, a signal triumph of modern astronomical science?

Nevertheless, the fulfilment of predictions alone will not always suffice to prove the absolute truth of the views upon which they are supposed to be based, or else the prediction of eclipses by astronomers who followed the Ptolemaic system would have proved the truth of that erroneous theory.

Bearing in mind, however, the aim and end of physical science, let us next glance at the only means which it is in the power of scientific men to use. These means are the employment of present sense-impressions, together with the reproduction in the investigation of groups of past senseimpressions.

All our knowledge is called forth by the play of surrounding nature upon our sense-organs; nor can we imagine anything which we have not previously had sensuous experience of-at least in its elements or component parts.

Again, there is a quality of distinctness and vividness in our sense-impressions. How vague, for example, is our imagination of a perfume, compared with our imagination of a visible triangular figure, or of a cube, or of a ball, held in the hand?

It is especially what is visible and tangible that comes home most readily to the imagination ; vague internal sensations are always described by us in terms of sight or touch. We speak of a 'gnawing' pain, a 'sharp' pain, like a knife, a 'rough' taste, and even a 'bright' intellect, and a ' hard' heart.'

Now, the 'explanation' of any phenomenon may be its reference to the causes which produce it; but its 'explana-

\footnotetext{
${ }^{1}$ See ante, p. 282.
} 
tion' is very often nothing more than the assigning of some new or unfamiliar object to a class of objects which has. already become familiar; and our minds are so formed that they feel an almost inevitable satisfaction in the reference of some object or action, difficult or impossible to imagine, to a class of objects or actions easy to imagine, and this whether or not such reference, when closely examined, turns out to be really justifiable, and therefore truly satisfactory.

Now there is nothing so easy for us to imagine as the motions of solid bodies, phenomena which appeal both to sight and touch. Thus it is that (apart from scientific utilities we shall shortly refer to) 'heat,' 'light,' 'chemical phenomena,' the action of nerves and of brain cells, are apt to appear easier to understand, and to be more or less 'explained,' when they are spoken of as 'ModEs of Motion.'

Nevertheless, such an explanation of the action of living beings is, as we have said, shocking to common-sense, and therefore, as has just been mentioned, another force was invented to account for them, and the actions of living beings have been explained as being due to the energising within them of a 'ViTAL Force.'

But the doctrine of the existence of any such force has been more and more successfully opposed by men of science on the ground that (1) living beings are not isolated phenomena in nature, but are affected by and react upon all physical forces; (2) that no distinct evidence is forthcoming of the existence of any such 'vital force'; and (3) that while the use of such a conception in no way furthers the ends of science, the mechanical conception of nature aids in the discovery of natural laws, and has powerfully helped on the progress of science.

And it is true that living beings are far indeed from being isolated; for the life of each of us largely consists of an 
interplay between what we consider our own body and environing nature. So intimate, in fact, is the connection between each of us and his environment, that it is even difficult to determine, in minute detail, the line of separation between the two. Food, even when swallowed, is far indeed from having become 'the tissue it is destined to renovate.' Even when digested and entering the absorbents which convey it to the blood-vessels which carry it to the intimate tissues of the body, who can say exactly how soon the foreign substance becomes the living being, or precisely when and where it is transformed into our very substance? It is the same with the streams of air carrying inwards the life-sustaining oxygen and outwards the deleterious vapours. By such agencies the outer world blends with us and we with it. Far from finding any such indubitable evidence of the existence of a 'vital force,' as we have of those phenomena we speak of as 'heat,' 'motion,' and 'light,' each living organismthus viewed purely from the standpoint of physical science - seems, in the words of a distinguished German philosopher, Lotze, only as a place in space where the matter, the forces, and the motions of the general course of nature meet each other in relations favourable for the production of vital phenomena. These phenomena excite our admiration, as do the phenomena of heat and pictorial transmission in that part of space near a lens which is called its 'focus.' Yet the phenomena of the focus are not explained by any peculiar force common to all 'foci' (and so comparable with the agency of 'vital force'), but are scientifically accounted for by light and the agencies of media of different densities, through which it is said to be transmitted.

The life of an organism may be compared (from the physical science point of view) to the quiet light of a wax candle which seems, to the uninstructed observer, to be the simple action of what he calls 'fire,' while to the man of 
science it is a most complicated series of changes, chemical and physical-oxygenation, decomposition, the formation of water, capillary attraction, etc., etc., all of which must be taken together to explain by their diverse simultaneous activities the apparently simple effect.

But not only is the existence of a diffused 'vital force' not demonstrable, and not only do men of science jield to a general tendency of human nature in imaging forth the world's activities generally, in terms of moving matter; but they very properly advocate the use of a means which experience has shown them to be most efficacious for their own legitimate end, which is the progress of physical science. The wonderful discoveries which modern research has made, have been made, not by investigating the ebb and flow of an imaginary 'vital force,' but by the application to the study of living nature of the previously ascertained laws of chemistry and physics. The discovered laws of the phenomena of digestion, of respiration, of the circulation of the nutritive fluids, etc., are all instances of the successful application of physics to the investigation of the phenomena of life. To that fruitful source alone we have also to look for the remedies of the physical ills of bodily life, for the perfecting of the trained skill of the physician, as well as, and no less than, that of the more obriously mechanical art of surgery.

Physical science can repose upon and appeal to nothing but things evident to the senses. It is thus compelled to make use of a mechanical imagination of nature, and no blame can therefore attach to physicists who regard this as their practical ideal, and attend exclusively to the physical forces, disregarding that discredited figment termed 'vital force.'

Should we, then, really accept the mechanical theory of the universe as an ABSOLCTE TRCTH? and are we to regard 
the world of animals and plants as presenting no really essential difference from that of the inorganic world?

We are far from thinking men are compelled to do this, and we will endeavour briefly to give our reasons why we think men are not so compelled.

Physical science is great, but it is not everything; and it cannot, by its very nature, be supreme. It essentially reposes upon our sense-perceptions, but it is not 'sense,' but intellect,' which is and must be supreme in us. It is not ' sense,' but 'thought,' which tells us that we have senseperceptions at all, and which criticises them and makes use of them. They are the indispensable servants of our intellect; without them it cannot move a step, but they are none the less its servants. Though we can have no imagination, and therefore no thoughts, till our minds are roused to activity by the action of the world about us on our senseorgans; though we can imagine nothing, of the elements of which we have not had sensuous experience, nevertheless we gain through the ministry of sense that which is not sensuous, but which regulates our every thought and rational action. The great principle, called that of contradiction, which lies at the root of our intellectual life-the principle that nothing can, at the same time, 'be' and 'not be,' may be taken as the type of conceptions which are gained through sense, but are not of sense.

Reason in man is supreme; and it relates to those first principles which have been recognised by one of our best-known living biologists as 'underlying all physical science.' Great therefore, as may be the utility of a mechanical view of nature, fully justified as men of science are in making use of it, and advocating its use for their own ends, it by no means follows that we should regard this useful working hypothesis as the very truth! We should or should not so regard it according as it may appear when viewed, not in the light of 
physical science, but in that of philosophy, which is the judge of physical science.

Here, then, we may return, for a moment, to the consideration of nature as the arena for the play of forces, whether 'physical' or 'vital.'

It is, as we know, the scientific fashion of the day (and a practically useful fashion) to regard the phenomena of living beings as 'physical,' and to also consider the various physical forces, heat, light, chemical affinity, etc., as so many modes of motion.

But when we raise ourselves above the horizon of physical science to the broader outlook of philosophy, can we then regard this practical reduction of all things to 'motion' as really an explanation?

We have freely conceded that 'vital force' is a figment, but what are we to say of heat, light, and motion also? Are they realities?

In fact, they are in themselves nothing more than abstractions of the mind. There is no such thing as 'heat,' or as 'motion'; though, of course, there are numberless warn bodies of different temperatures, while as to the quality ' moving,' nothing, so far as we know, is absolutely at rest. But they are commonly spoken of as if ther were not mere qualities of bodies, but actual substances, which may pass from one body into another and mutually transform themselves. To explain the phenomena of living beings, then, by 'mechanical motion,' however practically convenient for the investigation of physical science, is, from the point of view of pure reason, a philosophical absurdity. It is an attempt to explain them by a nonentity-a mental abstraction from a certain quality found in things. Moreover, as living creatures make known to us various different 'qualities,' to attempt to explain them all by different quantities of one only quality is an attempt to extract the 
category of QUALITY out of the category of QUANTITY, which every one at all versed in philosophy will recognise as a self-evident absurdity.

Please recollect that we are in no way objecting to the use of such conceptions as that of the 'transformation of force' for the purpose of aiding calculations and for general advance in physical science; we only object to the incautious use of such language as may lead persons to believe that 'forces' are substances, or to the notion that such conceptions are really profound truths; as if we really knew physical motion better than we do thought or will.

What essential distinction, then, does there remain to draw between living beings and beings devoid of life? There remains that distinction which was drawn more than two thousand two hundred years ago by the greatest of philosophers, and which has the advantage of agreeing with what common-sense tells us to-day.

It is the view that each living being, in addition to possessing those properties of which the senses inform us, also possesses, or rather Is, a unifying principle, ' a principle "f individuation' which altogether escapes the cognisance of our senses, though reflective reason agrees with commonsense in assuring us that it is by it that an animal concentrates into one centre the multitude of impressions made simultaneously and successively upon its various organs of sense.

This view, at onceTpopular and philosophic, has of late years received a remarkable adhesion from one who has been amongst the foremost advocates of a mechanical conception of nature. We refer to the German philosopher, Hermann Lotze, ${ }^{1}$ a man free altogether from theological or other prejudices or prepossessions. Moved alone by a profound and patient exercise of his reason, he has come to

${ }^{1}$ See ante, p. 279. 
enunciate in the most uncompromising way that view (so long ago maintained by Aristotle), the existence in each living being of a 'psyche' - a term most difficult to render into our own tongue because of the misleading connotation of the word 'soul,' which is its nearest English equivalent.'

The existence of such an internal principle in ourselves, is the most certain object of all knowledge. It is conceivable that we may doubt as to the existence of our body, but it is absolutely impossible to doubt the existence of a something which is actually thinking and feeling, and which recollects more or less of its own past. This knowledge, as to our own nature, enables us to conceive the existence of a principle of individuation in other living beings, though we can never imagine such a thing, which, as Lotze says, is as impossible as to know how things look in the dark. ${ }^{2}$

The recognition of the existence of this principle, however, is a matter of philosophy, or pure science, and not of mere physical science, which must ignore it, since it cannot rise to its recognition without going beyond its own province, which is nature, as cognisable to us in and by our senses.

Nevertheless, physical science may serve to confirm the teaching of philosophy, inasmuch as the whole tendency of modern researches is to show that living creatures do not arise except from antecedent living creatures and refutes the notion of 'spontaneous generation.' We have no disinclination to believe in spontaneous generation; we confess, it has been with reluctance that we have found ourselves forced by experimental evidence-especially by the evidence adduced by M. Pasteur, to whom we are all so greatly indebted-to reject all belief in it.

According to our present knowledge, then, a great gulf yawns between the living world and the world devoid of life-a gulf which nothing we can imagine seems capable

1 See ante, p. 216, note.

2 See ante, p. 287. 
of bridging over. It is true that certain physicists think that though spontaneous generation cannot take place now, it must have taken place a long while ago; but if asked why they think this, they have no reply but that they cannot otherwise imagine how living creatures could have ever come to be! But we have had no experience of creatures 'coming to be.' No wonder, then, if we cannot imagine it; for we can imagine nothing of which we have not had sensuous experience. The wisest course, I venture to think, is at present to say that physical science affords us no ground for affirming anything one way or another about the mode in which living things came to be, though it affirms the fact that all our experience is against the spontaneous origin of living things.

If this conception, that the essential, intimate nature of living things is something beyond the reach of the senses, commends itself, on reflection, to the reader's reason, he will then see how pregnant with true philosophy, and how essentially sufficient is the popular, common-sense reply to the question, 'What are animals and plants ?' namely, the answer that 'they are living things,' in so far as it implies that each has its own principle of individuation and of spontaneous internal activity.

Apart, however, from the acceptance of this view, we have seen that the totality of animals and plants form together a single immense group of creatures, possessing the ten characteristics which we have hereinbefore briefly enumerated, namely, that they are more or less rounded, aqueous, protoplasmic bodies, of very uniform chemical composition-breathing, feeding, secreting, and growing by intussusception, according to definite laws, reproducing their kind by a series of cyclical changes, and more or less able to form habits through their internal spontaneity.

Such is our answer to the first question: 'What are 
animals and plants, as contrasted with substances which are neither the one nor the other?' It remains to say a few words as to the second question-that concerning the relations of animals and plants, one to the other.

At first sight nothing could seem more obvious than the distinctness of animals from plants; but a very little science soon shows that to draw a distinction is not so easy a matter. Elaborate and recondite distinctions have been, one after another, drawn out, but these have, one after another, broken down, until there remains no one character which can be at the same time affirmed of all animals and denied of all plants (or vice versa), while these two great groups remain such as they are generally taken to be, the creatures known as Protozoa being reckoned as animals; that is, the lowest socalled animals, the bodies of which are not constituted of 'tissues.'

Let us look at these distinctions, beginning with the most obvious :-

1. The first of these relates to external form. The predominant branching vegetal form is denoted by the word ' c arborescent,' but many species of the animals (allied to the Corals) are arborescent also, while multitudes of the lowest plants are more or less spheroidal, and some are worm-like in figure.

2. Secondly, locomotion is common to almost all animals, but some are permanently fixed, like plants, while certain lower plants, especially in the earlier stages of their existence, are actively locomotive.

3. Animals generally live on more or less solid food, which they take into an internal digestive cavity. All animals, however, do not do this, notably the Entozoa, while certain plants are said to more or less nourish themselves on captured prey, as is the case with Venus's fly-trap and Dionœa (the sun-dew), while others, as the Pitcher plants, 
can receive them into a cavity, which is, to a certain extent, comparable with the animal alimentary cavity, since that is, morphologically, but an involution of the external surface.

4. Plants generally contain a greater amount of nonnitrogenous material in their composition than do animals generally, but this distinction is of little avail as regards the lowest forms of life of both groups.

5. Plants generally have a less evident power of forming habits or of responding to stimuli by increased activity; but this again does not serve as a distinction as regards the lower plants and animals.

6. Until quite recently it could be said that no animals possess that power of liberating carbonic acid and fixing carbon which is possessed by plants; but now it is known that certain worms also exercise this power. Nevertheless, we may still say that plants generally possess the power of feeding directly on the inorganic world and building up organic matter from it, while the animal kingdom has it not; and this difference constitutes what is sometimes spoken of as 'the circulation of the elements.'

Until the other day it could have been said that with the exception of a lowly species called myxomycetes, all plants were organisms composed of one, few, or many small masses of protoplasm, separated from each other by partitions of a non-nitrogenous substance called 'cellulose,' while in animals the protoplasmic particles were not so separated. Quite recently, however, it has been found that in some, and probably in very many if not in all plants, protoplasm is continuous, passing by minute filaments from cell to cell, through such cellulose partitions.

With the failure of this dfferential character, the very last distinction between the two kingdoms, as ordinarily understood, falls to the ground. We must profess ourselves 
utterly unable to frame any definition which shall at the same time include all kinds of one of these two groups, while excluding all kinds of the other group.

Nevertheless, it is obvious that there is an immense difference between animals and plants generally-a difference well expressed by that common-sense assertion we quoted at starting, that 'animals are creatures which get their living by the help of their senses, while plants are senseless.' Now, this common-sense view accords with the distinction drawn so many centuries ago by Aristotle, that animals feel, while plants do not.

In biology, however, groups are characterised by structure rather than by function, and we know, moreover, that every difference in 'function' has some difference in 'structure' as its accompaniment. But what is the structure which is related to the function of feeling? It is the nervous system. 'Nervous tissue' is the 'organ of feeling,' and modifications of it, with accessory accompaniments, constitute every organ of special sense, i.e. of sight, hearing, smell, taste, and touch.

Now, no plant is yet known to possess anything like nervous tissue, and the same may be affirmed of the lowest organisms commonly recognised as animals. We know at present no way of defining a plant save the negative one of saying 'a plant is an organism which is not an animal,' while the essence of animal life seems to us to be the power of 'feeling,' together with its necessary correlate, the 'possession of a nervous system.' If, then, we must draw a hard-and-fast line between the two kingdoms, we see no way left for us but that of transferring to the vegetal kingdom those lower organisms generally reckoned as animals, which possess no nervous systems. To botanists they will perhaps be an unwelcome present, but they can hardly be refused on any valid scientific grounds. The activity and irritability of many of them are, no doubt, very suggestive of animal life, 
but so are the activities of some of the lowest organisms always recognised as plants-many of the Algæe, especially in their younger stages and reproductive parts, together with such curious plants of prey as Venus's fly-trap and its allies -lately referred to.

We do not, indeed, yet positively advocate, though we regard with favour, such a mode of dividing the two component groups which together constitute animated nature; but we confess that we see no possible manner in which these two predominently diverse groups of organisms can be divided, if the whole mass of living creatures which we have seen to be so sharply and distinctly separated off from the non-living world are to be completely, sharply, and distinctly separated, one from the other.

Thus, we venture to think, may at present best be answered the two questions with which we set out: (1) What animals and plants are, as contrasted with substances which are neither the one nor the other; and (2) How animals and plants stand towards each other; the answers to which constitute the only reply we know of to the fundamental question we have taken as the title of this paper: 'What are Animals and Plants ?' 


\section{WEISMANN'S THEORIES_THE BEGINNING AND END OF LIFE.}

Essays upon Heredity and kindred Biological Problems. By Dr. August Weismann. The Clarendon Press, Oxford, 1889.

$\mathrm{O}^{\mathrm{NE}}$ noteworthy characteristic of the latter half of the present century has been the increasing interest taken by the general public in the deeper problems which underlie the natural history of living organisms. At its commencement, the veteran anatomist, Sir Richard Owen, facile princeps of his class, had drawn the attention of many thoughtful minds to questions of biology. He had done so by his skilful restoration of the extinct gigantic birds of New Zealand; his elaborate monographs on the man-like apesespecially the gorilla-and his fascinating theories concerning the archetypal principles of our own bodily structure, and the essential nature of the processes of generation and repair. We recollect a brilliant lecture given at the College of Surgeons to a distinguished audience-whereof one of the most interested was the then Bishop of Oxford, Dr. Wilberforce-wherein were expounded certain far-reaching sugges: tions concerning the then little known lucina sine concubitu - a process termed Parthenogenesis by the learned Hunterian Professor of that day. But however industriously and well Professor Owen may have prepared the way for him who was to follow, it was Charles Darwin who first compelled attention 
to biology by the efforts he called forth from opponents, as well as by the admiration he excited amongst his followers and disciples. The interest thus forcibly aroused has never been allowed to drop, and it has been recently intensified by the writings of Professor Weismann of Freiburg, upon whom the mantle of Darwin is declared to have fallen by not a few admirers. Strange to say, the subject about which the Freiburg Professor has aroused men's minds of late is mainly the very same as that about which our own Hunterian Professor discoursed so learnedly some forty years ago. A great injustice has been unwittingly committed by those amongst us who, while lauding or criticising Professor Weismann, have failed to make any reference to the work of their aged and illustrious copatriot, ${ }^{1}$ who in many respects actually anticipated the ideas of the Freiburg Professor himself. The theories of Professor Weismann, which are now the subject of such earnest discussion amongst our leading men of science, deal especially with what concerns both the beginning and the end of life. Although they do not mainly refer to human life and death, yet the progress of science is continually making more and more evident the close relationship which exists between our own life and the lives of our humbler fellow-creatures-even the very humblest of them. Attention has also become increasingly concentrated upon the processes by which each individual animal or plant is developed from its germ. To this study was devoted the brilliant but far too brief career of the lamented Francis Balfour, of whom it is difficult to say whether he was more esteemed for his scientific knowledge or beloved for his most attractive personal qualities. Investigations concerning development and reproduction have been found to be exceptionally profitable scientifically, so that more varied lines of inquiry have converged upon that mystery of mysteries.

1 See his work on Parthenogenesis. Van Voorst, 1848.

VOL. II. 
The position which the minds of men interested in the study of living things has thus taken up in our own time, is more or less a return to that mental attitude which marked the earliest days of scientific investigation whereof we have any knowledge. A very large part of Aristotle's biological treatises were directed to this subject, and wonderful indeed are those five books, when studied in the light of our most modern theories. Not of course that such questions were not debated at a yet earlier period. Indeed, a passage in the second chapter of his second book shows that certain very modern theories were rife amongst his predecessors. These he refuted as he refuted Ionian materialism, and his influence for centuries preserved the world from errors of this kind. Owing to this, certain rational ideas about development were retained throughout the Middle Ages-ideas from which the microscopists of the last century went strangely astray.

Every one is now familiar with the word 'Evolution,' but during the controversies of the seventeenth and eighteenth centuries it was employed in a very different sense from that in which we now use it. The theory then in fashion was that of 'preformation,' according to which the embryo was a perfect miniature of the adult, its development being a mere process of growth, and the unfolding of what already actually existed. Such were the views of Swammerdam, Vallisneri, Boerhaave, Malpighi, and other celebrated observers. But the same arguments which led to such a belief as regards the individual, logically compelled its supporters to maintain that all the individuals destined to arise in the course of ages also existed 'preformed in miniature'- -such preformed germs existing one within the other in ever-diminishing proportions. This was the celebrated theory of 'emboitement' which, for speculative reasons, received the patronage of Leibnitz and Malebranche.

On the other side, our own immortal Harvey (1615) 
followed the teaching of Aristotle, according to which there took place a gradual formation of what previously had no actual existence but only a potential one. This view, known in modern times as Epigenesis, was strongly reinforced (in 1759) by the careful observations of Caspar Friedrich Wolff; but his efforts remained without effect for two generationsso firmly had the strange theory of 'preformation' become rooted in men's minds. It was deliberately adopted by the great physiologist Haller, was adhered to by Buffon and Bonnet, and not positively rejected even by Cuvier himself. Yet now it is upheld by no one, and the views of Aristotle, Harvey, and Wolff have obtained universal, unhesitating acceptance.

Another dispute was independently carried on concerning the predominant effect of paternal or maternal influences. From the most ancient times predominant influence was ascribed to the former, the maternal organism being regarded merely as an agent for nutrition. Ancient Indian teaching was but echoed by Eschylus ${ }^{1}$ in the words :-

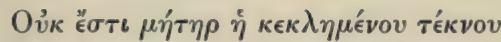

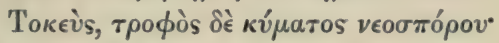

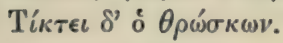

'The bearer of the so-called offspring is not the mother of it, but only the nurse of the newly-conceived foetus. It is the male who is the author of its being.'

Modern supporters of this view came to be known as Animalculists, ${ }^{2}$ their opponents being the Ovists. Both notions have now passed, along with 'preformationism,' into the limbo of discarded hypotheses, while the views of Aris-

${ }^{1}$ Eumenid., 658.

2 After the discovery by Leeuwenhoek and others of seminal particles which he considered to be animalcules. If the reader will refer to a German translation of Vallisneri by Berger, Erzeugung der Menschen und Thiere, he will see marvellous illustrations of the extent to which a prejudiced imagination may mislead an observer. 
totle (also expressed by Empedocles) have become solidly established through the researches of modern science. We now know that both these influences play their part, although it is still keenly debated whether or not there is any essential difference between them. This question, with the problem how and why the offspring resembles the parent to the wonderful extent it may, are amongst the subjects treated of in Professor Weismann's essays. Another relates to the first introduction of death into the world, and its bearing upon that 'struggle for existence' between species and species, with which the writings of Darwin and of Wallace have made us all familiar. He considers the whole mass of living animals and plants as divisible into two great groups, between which the strongest contrast exists both as to structure and vitality. The overwhelming majority of animal and vegetable organisms consists, as we do ourselves, of different kinds of substances-different tissues ${ }^{1}$-each made up of, or having been formed from, a multitude of cells. ${ }^{2}$ A natural death is now the inevitable fate of all creatures thus complexly formed. But there is another set of animals and plants, mostly of minute size, which each consist of but a single cell, and none of these, according to Professor Weis-

1 Such, e.g., as muscle, nerve, bone, blood, etc., each of which is a different kind of 'tissue.'

2 The minute structures termed 'cells' were first observed in plants, which indeed are mainly composed of them. Each cell is a minute bag with fluid contents, in which there is commonly present a certain denser body termed the 'nucleus,' as was shown by the illustrious botanists Robert Brown and Schleiden. This generalisation was subsequently extended to the animal kingdom by Schwann, and thus that general conception known as 'the celltheory' was promulgated. It became generally accepted about 1840. In 1849 Nägeli showed that the wall of the bag might be wanting, and by 1854 Max Schultze and others had shown that the nucleus also might be absent. Thus the 'cell' came to be regarded as a minute portion of semifluid substance, to which the now famous term of 'Protoplasm' came ultimately to be applied. This term was first used in a definite manner by Van Mohl, who employed it to denote the soft contents of the cell of plants. Within the nucleus of a cell a still smaller body is to be found known as the nucleolus, or nucleoli if more than one. Recent observers have discovered 
mann, can ever die a natural death. Like higher organisms, however, they have to take nourishment, which leads to growth. Such unicellular, generally spheroidal, organisms absorb nourishment at their surface and grow, but the effect of growth leads to a constantly increasing disproportion between their very rapidly augmenting mass, which needs to be nourished, and their much less rapidly expanding nourishment-receiving surface. The consequence of this must be either a state of stagnation, death, or-what really ensues - a process of spontaneous division by means of which a due balance of functions is for a time restored, followed by reaugmentation of bulk and renewed division, and so on continually. Obviously in a creature which divides into two exactly similar halves, each half has an equal claim to be considered as the continuation of the previously undivided whole, and this the more, since there is no evidence of any cessation of life during the process. Certainly there is no unequivocal corpse, and, as Professor Weismann observes, there can be no death when there is no dead body. But if the very living being of an organism is continued on by means of the two halves into which it spontaneously divides, then it must also be continued on into the subsequently and similarly divided portions of those halves themselves, and thus the being of the original undivided whole must also be continued on into all the organisms to which it, by its spontaneous division, gave rise. It therefore logically follows not only that each kind of unicellular organism is, accidents apart, immortal, but also that all the separate reprethat neither the structure of the nucleus nor that of the cell contents in which it is situated is simple, but that each contains a complex arrangement of most delicate fibres. Cells multiply by spontaneous division, and in so doing very singular and definite changes take place in the arrangement of these fibres, the sum of such changes being denoted by the term karyokynesis. The egg or ovum is a cell with its nucleus, the corresponding male project is but the nucleus of a cell with which a portion of cell contents is probably conjoined. 
sentatives of each kind may be regarded as together really forming but one self-segmented individual.

Such organisms, as being the simplest and lowest, are regarded by evolutionists as having been at first the only living creatures in the world. The formation of multicellular organisms, and the prevalence of death as we know it, the Professor accounts for as follows:-From time to time some unicellular organisms failed to subdivide themselves completely, and so, by degrees, carne to consist of aggregations of imperfectly divided, or at least of coherent cells. Some of these were better able, on account of their state of aggregation, to support the struggle of life, and were therefore preserved. They were the more surely preserved, by reason of the death and replacement of more or less of the individual cells of which they were composed. He tells us (p. 60):-

'The replacement of the cells of the tissues must be more advantageous for the functions of the whole organism than the unlimited activity of the same cells, inasmuch as the power of single cells would be much increased by these means. . . . The organism may thus, figuratively speaking, venture to demand from the various specific cells of tissues a greater amount of work than they are able to bear.'

Obviously an organism will be more vigorous and active if the cells of which it is composed have adopted the principle of 'the division of labour,' and mutually aid each other by respectively dedicating themselves to one function exclusively. But the consequence of such increased life must ultimately be death, through a failure in such cells to reproduce themselves, and without an adequate supply of all, the processes of life cannot be continued. Yet although a natural mortality, thus induced, must be fatal to the individual, it must be all the better for the race or species, provided the individuals only live long enough to sufficiently reproduce their kind.

Professor Weismann, however, affirms that the death of 
each kind of animal has come to take place naturally just at that time which is most beneficial to its species, and has so been fixed for each by the operation of natural selection. He argues that once the period of reproduction is finally over, any further survival of parental organisms must be prejudicial to the race, unless by their care of the young, or some other benefit to the community, they more than compensate for the loss of nourishment their survival occasions to the still reproductive members of the species. The Professor brings forward a great number of interesting facts with regard to the vitality of different groups of animals, and the facts brought forward by him of course tend on the whole to support his hypothesis. But the duration of life differs greatly in different creatures, even belonging to the same natural group.

As a rule, birds live long, and a white-headed vulture has lived for one hundred and eighteen years in captivity. This prolongation of bird-life Professor Weismann considers to be due to the very large proportion of eggs destroyed by enemies of so many different kinds, a circumstance which demands a greater production of young by way of compensation. Beasts, the immature progeny of which are sheltered within the maternal organism, lose much less, and consequently may produce less also, without risk to the permanence of the species. Most insects are short-lived in the final or imago stage of their existence. The Ephemerida, the female moths, Solenobia, and the male of Psyche calcella, do not live even one entire day in that condition. On the other hand, Sir John Lubbock has kept a queen-ant alive for nearly fifteen years, and a beetle (Buprestis splendens) has been known to live over thirty years. A very lowly organism (the sea-anemone, Actinia mesembryanthemum) has even been found capable of living for no less than sixtysix years. 
Even the males and females of the same species may differ greatly as to duration of life. There are certain minute parasites of bees the males of which only live for two or three hours, while the females will continue to exist for over a week. Whatever may have determined the period during which different kinds of multicellular animals live, there is no doubt that they have sooner or later to die naturally, if they escape all the various circumstances which occasion accidental death.

Nevertheless, just as the simplest unicellular organisms produce, without dying, others like them-by means of a process of self-division-so even the highest multicellular organisms produce, without dying, others like them by ineans of a process of self-division. For they separate off those reproductive elements, which subsequently initiate a new existence.

Therefore it would seem that there must be an immortal, corporeal part of every normal organism, however simple or however complex may be that organism's structure. The simplest creatures (as we have seen) are each immortal as a whole; but all the higher organisms are obviously and universally. mortal as regards the visible mass of their structure.

Therefore every multicellular organism, from a Medusa to a man, must consist of two parts:-(1) the great visible mass of the body, which Professor Weismann speaks of as the soma; and (2) some minute, ordinarily invisible, constituent, and such a constituent is affirmed by the Professor to exist and be transmitted, and this is named by him germplasm.

According to his views, if we return in imagination to the period when the first unicellular organisms were beginning to cohere in more and more complex aggregations, we shall see that, with the increasing division of labour amongst the 


\section{The Beginning and End of Life}

cells, some must have been set aside for reproducing not inerely themselves, but the whole complex organism of which they had come to form a part, and thus the distinction arose, between the general whole, or soma, on the one hand, and the contents-the germ-plasm-of such reproductive cells on the other.

In this way the mystery of heredity seems satisfactorily explained; for the continuity of germ-plasm is like the continuity of multiplying single cells. Since the continuity of the latter makes succeeding generations in a sense really one, there is little wonder that the child is like his forebears; for the continuity of the germ-plasm also makes succeeding generations in a sense really one.

But the Professor's theory carries with it one very remarkable consequence. If all the characters and powers possessed by every living creature are exclusively due to those portions of the parental organisms which consist of germ-plasm, it follows that no character acquired by the s.ma of either can ever be transmitted. However much bodily or mental activity may have developed the powers of a father, he can never hope to transmit to his offspring any similar capacity. All he can transmit must be such faculties as he himself brought with him into the world, and which were latent in the unimaginably minute structure of his own germ-plasm. All post-natal modifications of the soma, and all such mental acquisitions, Professor Weismann terms ' acquired characters,' and he absolutely and categorically denies that any acquired character can be transmitted.

Such is the great theory which has excited so much interest in the world of science, and has begun even to attract the attention of the general public. Such is the main contention of this disting'uished naturalist, upon whose shoulders, as we have said, the mantle of Darwin has descended, according to not a few of his admirers-admirers 
who mainly rest his claim to such distinction upon the fact of his having propounded this very theory.

We propose now to examine his theory, noting points in its favour, but also noting certain facts which seem to us to cast grave doubts on its validity and consequent permanence.

We will begin by considering the question concerning the inheritance of 'acquired characters,' and whether it is possible to believe that there is such a complete separation and distinctness of nature between the germ-plasm of a creature and the rest of that creature's body, as the Professor so unequivocably affirms to exist. In the first place he himself makes some noteworthy admissions, the consequences of which he does not appear adequately to appreciate.

Professor Hoffmann, of Marburg, has long been occupied in making experiments as to the effects, in producing variations, which'changed conditions may call forth in plants. He found that by cultivating certain wild plants in garden soil for several generations he could produce double flowers, change their colours, and also the shape of the green leaves of their foliage. He also found that the wild pansy could thus be made to produce larger flowers with different coloration, and that, after some generations, these changes were perpetuated through the plant's seed. This would seem plain evidence that acquired characters may be inherited, but Professor Weismann nevertheless denies it, affirming that the contained germ-plasm had thus itself become modified, so that the inherited changes were due to it alone, and not to the structure of the plant generally. But, in the first place, it is impossible to believe that a modification of enclosed and protected germ-plasm can take place, save through t'ie body-substance which so encloses and protects it, and therefore inherited character thus produced must be due to the response of such body-substance to the action of 


\section{The Beginning and End of Life}

its environment. Secondly, we may ask why is it less credible that the body-substance, or soma, should affect the germ-plasm, than that the germ-plasm should affect the soma? If the germ-plasm can be directly affected by physical influences which pass through the soma, on what possible ground can it be pronounced absolutely unmodifiable by the soma itself?

There are, however, certain facts which go far to demonstrate the direct action of the body-substance on the reproductive elements. Thus in the well-known case of Lord Zetland's brood mare which had a foal by a quagga, her subsequent progeny, though the offspring of thoroughbred horses, all bore quagga marks. It is also a fact familiar to dog-fanciers, that a thoroughbred bitch will produce imperfectly bred puppies if the father of her first puppy was a mongrel. Such cases prove both that the developing young may constitutionally affect the maternal organism (a fact pathologically evident), and that the thus constitutionally modified soma of the parent can modify the structure of the germs of its future progeny. But, indeed, pathological evidence on this matter is still much debated amongst experts; and Mr. Francis Galton, who has paid so much ttention to this subject, allows some transmissibility to acquired characters. One very curious point is the fact that the footprints of some insects seem so to have impressed themselves on certain plants, that the marks have become hereditary specific characters.

Another very curious and suggestive fact has been of late years ascertained by an observer named Yung, ${ }^{1}$ who ascertained that the sex of tadpoles could be changed by altering the nature and quantity of their food. Now no food

1 See his Contributions à l'Histoire de l'Influence des milieux physiques sur les êtres vivants, Archiv. Zool. Expérimentale, vii. (1878), pp. 251-282, and (1883) pp. 31-55; also Arch. Sci. Phys. Nat., xiv. (1885), pp. 502-522. 
taken into the body can possibly affect directly the organs thus modified. It can only do so through the action of the digestive organs and the circulation. Since change of sex necessarily implies changes in the germ-plasm contained within the organism, this amounts to a demonstration that changes in the soma can affect the substance which Professor Weismann regards as being so unmodifiable.

Our author argues at great length against the possibility of any transmission of mutilations. No doubt in the immense majority of cases such suddenly violently produced modifications are not transmitted, but there is nevertheless a certain amount of evidence that they occasionally are so.

An esteemed medical practitioner in the west of England informs us that a blood mare belonging to the late Sir F. Williams, Bart., on the night of the day she had been put to horse, was placed in an old stable prior to being turned out to grass for a summer's run. When the groom entered the stable the following morning, he found that the mare had lost one of its eyes, which he then found adhering to a rusty nail in the wall. In due course the mare gave birth to a foal with only one eye, and the same thing occurred in the following year. Afterwards she had foals with perfect eyes. The previous foals with only one eye each were without an eye on the same side of the head as that in which the injury to the mother had taken place.

From noting cases of injury, we turn naturally to consider instances of the repair and reproduction of lost parts in individuals which have sustained injury. Very remarkable instances of such repair occur sometimes in the human subject, but that which takes place in many of the lower animals is far greater. Thus if the tail of a lizard be broken off, it will grow again. The limbs of efts will also be reproduced, with their bones, muscles, blood-vessels, and nerves. Even the eye and lower jaw have been seen to 
be reproduced in the last-named animals. The legs and claws of lobsters will similarly grow again if removed at one of their joints. If certain worms be cut in two, each half will become a perfect animal, the head producing a new tail and the tail a new head, and a worm of the genus Nais has been cut into as many as twenty-five parts with a like result.

In higher animals, artificially separated parts often continue for a time to exhibit a certain vitality. A tadpole's tail will, for a short period, continue to grow, and a separate lizard's tail will also move rapidly. Frogs' amputated legs long continue to respond to stimuli. The heart will continue to beat on removal from the body, and after death the various tissues of the bodily frame continue for different extents of time to show signs of vitality. The animal which is perhaps the most remarkable for its power of repairing injuries is the Hydra, almost any fragment of which will, under favourable circumstances, grow into a new and entire animal. The sea-anemone (Actinia) has also very great power of the same kind. This process, which excites our surprise and admiration in the case of animals, is so familiar to us in plants, that no one thinks the formation of new individuals by 'cuttings' a matter of wonder. Certain buds also of some plants, notably tiger lilies, will detach themselves, and develop into plants like those which bore them.

We must confess that Professor Weismann's theory does not appear to us to harmonise with such facts as these. He attempts to explain them by affirming that the germ-plasm must be present in all such parts of divided or injured organisms. But it hardly seems credible that this hypothetical substance can be so distributed through the body that each part or organ should have just that portion of it needed to bring about its own repair when injured. As to the difference between the germ-plasm of the embryo 
plant and that which Professor Weismann supposes to be present in a bud, he affirms (p. 322) that it

'must be very slight, and perhaps quite insignificant, for it is possible that the difference between the secondary shoots and the primary plant may chiefly depend upon the changed conditions of development which takes place beneath the earth in the latter case, and in the tissues of the plant in the former.'

But in the seed of plants we may plainly see, as e.g. in the bean, the rudimentary stem or plumule, and also the incipient root or radicle, but no such rudimentary root is ever formed in the bud. Yet if there be real germ-plasm there, such as the Professor supposes, it is to us inconceivable that its mere situation should render such a fundamental structure as the radicle absolutely abortive.

But Dr. Weismann's position mainly reposes upon the great distinction which he draws between the lowest or unicellular animals, and all the other higher forms, from sponges up to man, which are known amongst naturalists as Metazoa. In drawing the great distinction he does, he but carries somewhat further that previously drawn by most zoologists along the same lines. We, however, have for years been inclined to regard the popular view with distrust. That view has been based upon what we deem an exaggerated estimate of the value and significance of the cell, as Professor Weismann's is based upon, what, in our opinion is an exaggerated estimate of the value and significance of the cell-nucleus. But recent discoveries have shown that early stages of individual development, which have been attributed exclusively to the activity of 'cells,' can take place without them, ${ }^{1}$ and that changes in the nucleus hitherto thought to be due to its own inherent activity are carried on by the agency of the surrounding substance, ${ }^{2}$

1 As in the archaic, insect-like creature named Peripatus.

2 See Boveri, Zellen Studien. Jenaïsche Zeitschrift für Naturwissenschaften, 1887-1888. 
which had previously been considered relatively functionless and inert. Although muscular fibres, as commonly understood, are products of cells, it has long been known that in some unicellular animals, as in the little Vorticella of our ponds, a practical equivalent exists within the stalk by which the creature is sustained, and which contracts with all the force and activity of true muscle upon the slightest stimulus. Now, however, Boveri gives us reason to suspect the existence of something essentially similar within the germ-cell itself, even before it has begun its process of spontaneous fission. We now also know that processes performed by the subdivisions of parts of the contents of the one cell of which such creatures consist, must be regarded as sexual processes, and such subdivisions themselves as practically sexual organs; so that from this point of view the minute organism becomes the equivalent of an entire higher animal instead of being the equivalent of merely one of its component cells. Thus if the higher animals are to be regarded as consisting of a soma containing germ-plasm, an essentially similar complexity must exist in unicellular organisms which are so far sexual, and Dr. Weismann's antithesis between them entirely breaks down. That such an essential similarity in minute structure does indeed exist has become a matter of direct observation. That veteran and prince of microscopists, Dr. Dallinger, has ascertained that in even the minutest and lowest organisins, precisely equivalent changes occur to those which take place in the nucleus of higher animals, and have been supposed (by Weismann and others) to show the distinctness between the germ-plasm containing chromatin, and the other constituents of the ovum. ${ }^{1}$

Further consideration will, we think, show that the anti-

1 See Dr. Dallinger's Presidential Address delivered to the Royal Microscopical Society on February 10th, 1886. 
thesis he draws between the immortality of the Protozoa and the mortality of the Metazoa breaks down also.

As to this matter, Dr. Dallinger has further observed that after a prolonged continuity of fission (measured by following persistently one-half of the fission in every case to the end), there comes a period of death-absolute devitalisation-to a majority of the individuals, after from six to ten hours, according to the species; while those which do not thus die fuse together, and end by producing a multitude of minute spores.

This perfectly agrees with what M. E. Maupas has also quite recently observed in Infusoria. ${ }^{1}$ After two hundred and fifteen generations had been produced by ordinary division, they either died a natural death, or blended with individuals derived from another source, and so ceased individually to exist.

One of the most curious of the Professor's hypotheses is that which denies all difference of sex, that is, of course, all essential difference. This denial is indeed but one aspect of his far wider denial of all differences of a qualitative kind (p. 101), to the consideration of which we shall return later. It is a fortunate denial, since certain consequences of the position he has assumed can be tested by observation, and have been so tested quite recently.

If, as the Professor affirms, there is no difference of quality between the sexes, then the fertilisation of flowers or insects can but consist in a modification of its quantity. But among lowly animals, certain so-called water-fleas, a few moths, wheel-animalcules, and the green aphides which so affect pelargoniums kept in dwelling-rooms, reproduce parthenogenetically. It follows, therefore, if Professor Weismann is right, that there must be a special quantitative difference between the ova of such creatures and the ova of allied ${ }^{1}$ Archives de Zoologie Expérimentale, 1888. 
forms which reproduce normally. This he unhesitatingly affirms, and stakes the validity of his view upon the alleged fact that while two 'polar-bodies' are expelled from ordinary ova, all parthenogenetic ova expel but one.

The ova of animals of the most varied kinds (but not so far as known of all classes) agree in the performance of a process, the meaning of which is much disputed. As each ovum becomes ripe for fertilisation it extrudes from one end, or ' pole,' a minute particle of its substance, and, a little later, another apparently similar. These extrusions Professor Weismann explains as nevertheless being of quite different natures. He declares that every egg contains two substances-one devoted to the completing the structure of the egg itself, and the other substance to the formation of the future young. The first particle excluded he declares to be formed of the eggmaking substance only; while the second he considers to be part of the essential reproductive substance, or germ-plasm of the egg. When this is, as usual, extruded, then, according to him, there does not remain enough of the germ-plasm for the formation of the embryo. This sufficiency must be made good by the addition of similar germ-plasm from without, and such he deems to be the only meaning of fertilisation. When, however, the second particle is not excluded, then, he says, enough substance exists for development without any addition from another source, and hence parthenogenesis takes place without difficulty. Now, in the first place we must observe his assertion that there are two such different substances in the egg is a mere hypothesis without a shadow of proof; and in the second place his assertion that the two particles extruded are really different in nature though apparently alike, is another mere hypothesis without a shadow of proof. But there is not merely an absence of proof, there is now proof to the contrary. Amongst the creatures which are parthenogenetically produced is the male, or drone, of voL. II. 
the hive-bee, and from the egg of this insect, it has recently been ascertained, a second polar body is extruded. ${ }^{1}$ Therefore, according to Professor Weismann, there cannot be substance enough for its development. But it is developed notwithstanding. Therefore fertilisation must be something more than a mere addition of like to like, and the male influence must have some difference in kind or nature from the female. This is the view now strongly held by that most indefatigable and rising young naturalist, Professor Geddes, F.R.S.E., of Dundee. He holds, and has quite lately brought forward a mass of evidence in support of his contention, that in every male element there is an essential activity compared with which the female is essentially passive and inert. It would be foreign to the scope of this article to pursue the details of this contention, but we note with exceeding interest that here again the most recent scientific advance harmonises with the views put forward so many centuries ago by Aristotle. The modes of expression are, of course, different. Professor Geddes employs terms familiar in the most recent physiological teaching, ${ }^{2}$ but when we come to analyse the ultimate signification of his terms, we find that, deeply considered, they are really reducible to the conception of the ancient sage of Macedonia.

But Professor Weismann's views are to be refuted by following out the consequences of his doctrine in another direction, and contrasting them with facts. He is an enthusiastic Darwinian, and ascribes all the adaptations met with in organic nature and all new species to that agency. As, however, he denies that any acquired character can be inherited, he derives everything from accidental variations in the disposition of the germ-plasm, by which an enormously

${ }^{1}$ By Blochman : see his paper on the polar bodies of the drone's egg, Morphol. Jahrbuch, vol. xv. part i. pp. 85-96.

${ }^{2} \mathrm{He}$ regards it as a difference of metabolism, the male being predominantly Katabolic, and the female Anabolic. 
increased task is placed upon natural selection. On this account he also denies that favourable variations can occur in parthenogenetic reproduction, or at least that it can be more than minute and insignificant when compared with the effects of ordinary reproduction. The Professor says (p. 275): 'If it could be shown that a purely parthenogenetic species had become transformed into a new one, such an observation would prove the existence of some force of transformation other than selective processes, for the new species could not have been produced by the latter.' But we have the authority of Professor Sydney H. Vines for affirming that new. species have appeared in parthenogenetic plants, and the same thing appears certainly to have occurred amongst the parthenogetic wheel-animalcules. But not only, according to Professor Weismann, are such forms unable to evolve new species, they are also unlikely to have themselves a long existence. But amongst the Fungi, a number of genera and species are admittedly parthenogenetic, and yet these plants exhibit not the slightest tendency to die out. These fungi, such as our common mushroom, fairy rings, etc., ' afford an example of a vast family of plants, of the most varied form and habit, including hundreds of genera and species, in which, so far as minute and long-continued investigation has shown, there is not, and probably never has been, any trace of a soxual process.' 1 Professor Vines may well ask how, on Professor Weismann's hypothesis, can all the variations and evolutions of new forms which have taken place in this group of organisms be accounted for? It appears to us to be a second absolutely fatal objection-that concerning the two polar bodies in the drone's egg being the first such.

But if the Weismann theory renders the evolution of new parthenogenetic species impossible, it appears to us to make the evolution of non-parthenogenetic species impossible also.

1. Nature, Oct. 24th, 1889, p. 626. 
According to him the germ-plasm has but one power and function, the exact reproduction of the form from whence it came. The germ-plasms of the parents can then produce nothing whatever which is new, and yet new forms have (as the Professor would be the first to assert) constantly and repeatedly arisen. He will no doubt explain these novelties as results of conflicting tendencies, producing in each case a tertium quid. But this is a mere verbal explanation which is equivalent to the abandonment of his whole theory. If the germ-plasms of each or either parent is thus modifiable, it is not, as he affirms, rigidly confined to a mere exact repetition of what it has been. It must possess some peculiar plastic power and a capacity for reciprocal influence which, when deeply considered, will be seen to be fully as mysterious as any of the phenomena the Professor set out to explain.

But the extreme complexity of his theory seems to us to be also fatal to it. He admits that the complexity of Pangenesis is too great for belief, but that of his own hypothesis is at least as great. He tells us (p. 191) that 'every detail of the whole organism must be represented in the germ-plasm by its own special and peculiar arrangement of molecules,' and (p. 146) that 'the number of generations of somatic cells which can succeed one another in the course of a single life is predetermined in the germ.'

Moreover, none of these circumstances can be explained by any difference of quality (since at p. 101 he has denied the existence of such a thing as quality), and must therefore be supposed to be due to differences in the size, number, and arrangement of the component parts, and to nothing else.

If we only consider what must be the complexity of the arrangement of minute structures in order that that arrangement alone may efficiently determine once for all in the germ, the precise number of all the epithelial scales of the skin which have to be cast off during the whole of sub- 
sequent life, as well as every one of the rapidly removed and replaced cells of all the glands of the body, and every blood corpuscle which shall be found between the first to appear and the last reproduced at the end of the longest life, we may well be astonished. But mere complexity of this kind is but an initial difficulty. We must also believe that every modification of structure, every process of healing and repair, and the nerve accompaniments of every feeling and thought in each one's life-history, must be similarly provided for in a definite manner at starting. In many animals great changes take place during life, the food and habits of the earlier stage of existence being widely different from those of the adult. Thus a small beetle, called Sitaris, instead of leaving its egg as a mere grub in the ordinary fashion, and subsequently changing into the adult, or imago condition, begins and ends its life in full activity, with an intermediate stage of torpidity. It is hatched in the nests of bees, and is at first active, and furnished with six legs, two long antennæ, and four eyes. It attaches itself to a drone-bee, and when the drones and the queen sally forth, passes to the latter. Subsequently, when the queen-bee lays her eggs, it springs upon one, and when enclosed with it in the wax cell, it first devours that egg, and then, transforming itself into a grub, feeds on the honey it finds ready to hand. Ultimately it undergoes another transformation, and reacquiring its legs, etc., emerges a perfect beetle! Now, according to Dr. Weismann, there must be present in the germ an arrangement of molecules such as infallibly to bring about all these processes, and provide at starting for all the complex changes of arrangement which may be necessary to build up reflex mechanisms capable not only of compelling complex instinctive actions occurring at one time of life, but of so successively changing as to be able successively to make necessary the successively 
occurring very different instinctive actions of different periods of life, as in this Sitaris and a multitude of similar forms. All this, he tells us, is to be explained exclusively by a mechanical arrangement of particles in the germ. Now Professor Weismann, in criticising Nägeli's hypothesis, which would explain heredity by 'conditions of tension and movement,' declares (p. 182) that 'it would be hardly possible to form even one approximate conception' of such an explanation. We confess to being in the very same position with respect to Professor Weismann himself. We do not believe that such an arrangement of particles as he supposes is a possible one-namely such an arrangement of particles in the germ as to enable mere shock and impact to produce all the phenomena of the life of a creature of a certain kind; including all pathological modifications and all instinctive actions. Such an hypothesis makes greater demands on our credulity than does even the now discredited theory of Pangenesis itself.

Professor Weismann is an enthusiastic Darwinian, and carries the principle of natural selection to much greater lengths than it was carried by the venerable naturalist who (with Mr. Wallace) promulgated it. Our judgment concerning that principle has been expressed without ambiguity, ${ }^{1}$ and to that judgment we firmly adhere. We shall therefore enter into no further controversy on the subject now, though we are compelled to notice certain of Professor Weismann's references to it. He would explain all adaptive phenomena and every specific origin exclusively by the preservation through natural selection of accidental differences in the disposition of particles within the germ, excluding all direct action on progeny, through modifications induced by the environment in the soma of their parents-a conception which of course very heavily handi-

${ }^{1}$ See ante, pp. 1-102. 
caps natural selection, and makes its acceptance as the one great cause of specific origin much more difficult. $\mathrm{He}$ believes all instincts to have been produced by it, and his confidence in that principle is so robust, that he does not hesitate to cite instances which may well stagger the faith of less devoted adherents. Thus he tells us (p. 93) :-

' The queen-bee takes her nuptial flight only once, and yet how many and complex are the instincts and the reflex mechanisms which come into play on that occasion! Again, in many insects the deposition of eggs occurs but once in a lifetime, and yet such insects always fulfil the necessary conditions with unfailing accuracy. . . It is indeed astonishing to watch one of the Cynipidce (Rhodites roses) depositing her eggs in the tissues of a young bud. She first carefully examines the bud on all sides, and feels it with her legs and antennæ. Then she slowly inserts her long ovipositor between the closely-rolled leaves of the bud, but if it does not reach exactly the right spot, she will withdraw and reinsert it many times, until at length, when the proper place has been found, she will slowly bore deep into the very centre of the bud, so that the eggs will reach the exact spot-and here the necessary conditions for its development alone exist. . . . It is the same with the deposition of eggs in most insects. How can practice have had any influence upon the origin of the instinct which leads one of our butterflies (Vanessa levana) to lay its green eggs in single file, as columns, which project freely from the stem or leaf, so that protection is gained by their close resemblance to the flower-buds of the stinging-nettle, which forms the food-plant of the caterpillars?'

How, we may ask in turn, can natural selection have produced so admirable a result by mere chance variation in the collocation of the molecules of the germ-plasms of a creature which before had them not?

It has of late been ascertained that the gall which is found in plants punctured by the ichneumon-fly Cynips, is not produced as was supposed by the effect of the puncture itself. It is produced subsequently by the movements of the larva which is hatched from the egg laid by the Cynips when it effected the puncture. The presence 
of this small moving body so stimulates the plant as to produce a definite result - the growth of the gall. This growth is useful enough to the grub, but is certainly useless to the plant, if not more or less prejudicial to it. It is surely too much to ask us to believe that the germ-plasm of the plant, in the first instance, before even, say, a single Cynips had visited it, had had the particles of its germplasm so arranged as to compel the plant to grow a complex structure beneficial not to $i t$, but to its parasite! Surely the action of natural selection would have led to the formation of a secretion or growth suitable for killing the intruder, not for nourishing and sheltering it! Professor Weismann's whole system is built up on Natural Selection. One instance therefore really irreconcilable with the latter theory is necessarily destructive to his own.

More nearly connected with the question of instinct than may at first appear, is the question of death-its nature and its origin. We have already seen how the Professor attributes immortality to unicellular organisms, and asserts that death becomes established through the benefit thence arising to the race; but its absolutely first occurrence is very inadequately explained, nor can we agree with his representation of what death is. In the first place, why did cells which had been immortal for untold ages begin naturally to die? The Professor affirms (p. 29) it to be 'conceivable that all cells may possess the power of refusing to absorb nutriment' - a refusal necessarily fatal to them. But we are quite at a loss to conceive why a cell should begin to practise so extraordinary an abstinencean abstinence for which no foundation had been laid in its forebears, from whose spontaneous division it had itself resulted. We do not regard such a process as conceivable, though it is imaginable enough-as are a countless number of admitted absurdities of all kinds. The absolute origin 


\section{The Beginning and End of Life}

and nature of natural death our author leaves as mysterious as he found them. We are certainly far from professing to be able to explain death. Indeed we strongly suspect that it must remain inexplicable till life, its opposite, can be accounted for and explained. In our eyes death can only be a consequence of something which causes a natural revival of a dead organism to be impossible. But what can that something be? Here Professor J. S. Burdon Sanderson comes very appositely to our assistance. The luminous and highly suggestive remarks he has recently made in his address to the Biological Section of the British Association (at Newcastle) should be carefully read and maturely pondered over by all those who are interested in that at once most familiar and most obscure of all subjects of investigation-life.

Adopting as a fundamental principle the constant correlation between function and structure-of the form and organisation of parts with the active processes they perform-he proceeds to show how microscopic observations have been altogether outrun by physiological investigations, so that structural conditions have to be imagined, which are altogether unverifiable by sight, however much it can as yet be aided by art. In considering the ultimate lessons to be derived from the subject he selected for exposition, Professor Burdon Sanderson, in concluding his address, uses the following pregnant words :-

'The word Life is used in physiology in what, if you like, may be called a technical sense, and denotes only that state of change with permanence which I have endeavoured to set forth to you. In this restricted sense of the word, therefore, the question, "What is Life?" is one to which the answer is approachable; but I need not say that in a higher sense-higher because it appeals to higher faculties in our nature - the word suggests something outside mechanism, which may perchance be its cause rather than its effect.

'The tendency to recognise such a relation as this is what we 
mean by vitalism. At the beginning of this discourse I referred to the anti-vitalistic tendency which accompanied the great advance in knowledge that took place at the middle of the century. But even at the height of this movement there was a reaction towards vitalism, of which Virchow, the founder of modern pathology, was the greatest exponent. Now, a generation later, a tendency in the same direction is manifesting itself in various quarters. What does this tendency mean? It has to my mind the same significance now that it had then. Thirty years ago the discovery of the cell as the basis of vital function was new, and the mystery which before belonged to the organism was transferred to the unit, which, while it served to explain everything, was itself unexplained. The discovery of the cell seemed to be a very close approach to the mechanism of life, but now we are striving to get even closer, and with the same result. Our measurements are more exact, our methods finer; but these very methods bring us to close quarters with phenomena which, although within reach of exact investigation, are, as regards their essence, involved in a mystery which is the more profound the more it is brought into contrast with the exact knowledge we possess of surrounding conditions.' 1

These words point clearly to what we take to be one of the profoundest and most important truths in the whole range of science; one which may be called the very truth of truths of biological science. It is a truth which has the most direct and important bearing upon all those laws of life to the investigation of which Professor Weismann has devoted so many years and so much labour. He is a worthy worker in the cause of science, and yet, like not a few of his fellow-workers, he strangely under-estimates and misrepresents that good cause of which he is, in a subordinate field, so zealous a servant. Scientific knowledge, par excellence, is and must be the most complete, accurate, and certain knowledge attainable by man. We do and should speak of the science of botany, the science of mathematics, the science of history and biological science; but when we use the word 'science' simply by itself and without qualification, it should ${ }^{1}$ Nature, vol. xl. No. 1039, Sept. 26, 1889, p. 521. 
be used to denote that which is the highest and most certain science. No branch of science can arrogate exclusively to itself that which is common to all sciences, and still less that to which it has itself to appeal to establish when need be its truth and validity.

The word 'science' thus used should denote the highest and most certain knowledge to which we can attain-namely the knowledge of necessary truths, of the laws of thought, and the fact of our continuous existence.

If we cannot reason validly we can infer nothing with certainty, and there can be no such thing as science, and the same destructive result follows the negation, or non-affirmation, of necessary truth and the continuity of our own personal existence. To doubt such continuity is to render every operation doubtful, and is logically fatal to any scientific certainty whatever. To doubt about necessary truth is the most destructive and absurd of all dubitation. To any one who should object that we cannot know such a truth, and that nothing can both be and not be at the same time, it may be replied that 'if we know necessary truth at all we know that truth,' and no one can deny that this hypothetical assertion is absolutely, necessarily, and categorically true. This alone, therefore, suffices to demonstrate that such truth does exist and is attainable. It also suffices to demolish materialism and the absurd conceptions of mechanical philosophy. For if we affirm that we know anything material at all, and any forces which are only physical, we are compelled yet more strongly to assert an existence which is immaterial and non-mechanical.

For we know intimately by and in our own consciousness, something continuously existing, conscious of successive objects and events, and capable of holding all of them before it in one conception, as parts of a series which it transcends. Such a principle, aware of the kinds and directions of its 
activities, present to them all, and capable of reviewing its own states and external objects and events in various orders, cannot itself be multitudinous, but must be as much a unity as anything we can think of. If then we do know any material bodies, any physical force at all, it is simply certain that this principle is neither the one nor the other, but stands out in the strongest contrast with both. Thus since each man knows that it is he who merely feels as well as he who thinks, he knows, if he reflects upon it, that if he has a body, his body and his thinking principle are to his experience one unity-he knows that he is a unity with two sets of faculties, material and mechanical in one aspect, immaterial and non-mechanical in the other aspect. No certainty we can attain to about any other objects can be nearly so certain as this certainty which we have about our own being; first, its dynamic, immaterial aspect, and secondly, its material, mechanical aspect. That each man is a material, definitely organised substance in one unity, with a dynamic, immaterial principle of individuation revealed in consciousness, is the first truth of physical science. It is emphatically the fundamental truth of biological science; for biology deals exclusively with living things, and of no living thing can any one have so complete a knowledge as of himself.

Looking out upon the world about us we find a multitude of living beings, the world of animals, more or less like us, some of them so evidently like us, we cannot but deem it probable that each such being is also the seat of an immaterial, dynamic principle of individuation, however different in kind and in powers it may be from our own. Extending our gaze over nature, we find on all sides of us a network of living animal and vegetable forms so like each other, in spite of small gradations of differences, that we cannot well draw a line, and say below it, such living creatures have no such dynamic individuating principle. 
All analogy is in favour of this view of nature, and no one fact in nature is in contradiction or out of harmony therewith. Its acceptance throws light on the phenomena of growth, repair, reproduction, development, and specific evolution. The words above cited from Professor Burdon Sanderson fully harmonise with the view. As he says, the discovery of cells served for a time to discredit vitalism, because men jumped to the absurd conclusion that, because another step in the mechanism of nature was discovered, all that was non-mechanical was thereby abolished. It is ever thus when physical science turns on a fresh limelight. Men, who have not sheltered their mental vision by a medium of philosophy, are thereby dazzled and temporarily blinded. Such fresh illuminations are continually recurring, and as soon as the retina of the intellect becomes accustomed to the novelty, the old lines, temporarily invisible, become plainly recognisable once more with, as Professor B. Sanderson says, 'the same result.' Without such a dynamical conception as we advocate, merely mechanical hypotheses show their insufficiency one after the other in an invariable succession; whereas, being reinforced by this conception, they have just that aid which is needed for their validity. Similarly the conception of dynamic principles of individuation in nature is, taken by itself, unsatisfactory and insufficient. We must, as Professor B. Sanderson says, 'ever have structure and function in harmonious correlation.' The ultimate structural elements of bodies are beyond the range of anatomical microscopic examination, as the ultimate dynamic agencies are beyond the range of detection in the physiological laboratory. Both, though thus beyond the scrutiny of the senses, are alike within the range of the fully instructed student of nature's mental vision. Here, as in so many other instances, it is only what is unpicturable to the imagination which is satisfying to the cultivated intellect. 
With this conception of life we might with more hope enter upon the question of the essential nature of death. But our present space is exhausted. We can but reiterate that, thus considered, death may well be 'a consequence of something which makes natural revival impossible.' What that something is, physical science at least can never tell us. If life consists, as we believe it does, in the presence of an immaterial principle of individuation, then death must consist in the absence of that principle. The conception of the appearance and the disappearance of such principles in nature is obscured by the demand of the imagination to know 'where' such entities can go to, or 'whence' they may have come-for spatial and temporal relations are necessities of the imagination. We know, however, that the intellect can transcend the imagination, and though we cannot reply in terms which may satisfy the bond-slave of the imagination, we can do so effectually for him who has gone beyond sense to the freedom of thought of the intellect. As an illustration, we may say that when a man is reading a book by the light of a candle his eyes are fixed upon its pages, and there is so far a union between those pages and his organs of vision. Let the light be suddenly extinguished; there need be no movement of the eyes or of book, and yet that union which before existed between them has nevertheless ceased to be, and has been followed by separation. The relation which previously existed has not gone anywhere, though it has actually ceased to be, and has lapsed into a mere potential existence. Let light be restored, and the union which previously existed may be restored also. Yet if it is so restored it does not come from any place, though it none the less has definite spatial relations as soon as ever it actually exists. The categories 'whence' and 'where' apply only to material existences, and to our own imagination as being so intimately connected with existences of that kind. 


\section{The Beginning and End of Life}

We have been led to these reflections by our apprehension of the bearing upon Professor Weismann's theories of the declarations of Professor Burdon Sanderson, and before terminating this article we must cite a few more of our Oxford Professor's words of wisdom.

Speaking of merely physical inquiries, he observes :-

'Let those who are so inclined cross the frontier and philosophise; but to me it appears to be more conducive to progress that we should do our best to furnish professed philosophers with such facts relating to structure and function as may serve them as aids in the investigation of those deeper problems which concern man's relation to the past, the present, and the unknown future.'

Most cordially do we echo these judicious words which form so striking a contrast to the declarations of mere physicists of the School of Haeckel, who, arrogating to themselves the title of 'Men of Science,' attempt dogmatically to explain the phenomena of nature, including the mind of man and all its powers and attributes, on a material basis alone, judging them exclusively by a consideration of anatomical' structures and physical forces.

In concluding our brief review of Professor Weismann's hypotheses, we desire to express our thanks to the naturalist of Freiburg for his many valuable labours. If we deem them without result as affording support to the philosophical views he appears to favour, we are none the less confident that they are full of interest and profit for biological science. Nor do we doubt but that they will also conduce to the advantage and development of the highest science also, although we are persuaded that these ultimate effects will be widely different from those which their learned and accomplished author himself contemplates. They have already had the effect of greatly stimulating inquiring minds and directing research into new channels, and we have so high an opinion of Pro- 
fessor Weismann, that we feel sure he will be sufficiently consoled for any non-acceptance of his special hypotheses by a clear perception that his enunciation of them has importantly accelerated and aided the pursuit and attainment of higher scientific truth. 


\section{EIMER ON GROWTH AND INHERITANCE.}

Organic Evolution as the Result of the Inheritance of Acquired Characters. By Dr. G. H. Theodor Eimer. Translated by J. T. Cunningham, M.A., F.R.S.E. London, 1890.

COULD 'the Father of Experimental Philosophy,' with his Novum Organum under his arm, once more visit the scenes of his earthly pilgrimage, he would certainly view with a qualified approbation the present aspect of some physical science. He would, no doubt, feel great delight at the wonderful progress which has, in so many directions, been achieved. He could hardly fail to be gratified by the tributes to his method, and still more to his spirit, which he would everywhere meet with. Nevertheless, when he came to understand what the current scientific conceptions of our day are, and what the nature of the questions most keenly debated by the men who have caught the popular ear, his surprise would not be an altogether pleasurable one. His keen disapprobation would certainly be called forth by the extent to which he would find that mere speculation had passed beyond the safe and modest bounds of either direct observation and experiment, or of sure and valid inference. In the first half of the present century the speculative dreams of our Teutonic neighbours were trite subjects of ridicule. We laughed, not without reason, at the farthing'sworth of fact on which such an unconscionable quantity of theory was too often based. But the century's second half finds not a few Englishmen following suit, although, we

VOL. II. 
rejoice to say, without the fantastic extravagances which are now to be found at Tübingen or Jena, as others were at Göttingen in the days of our fathers.

We are singularly fortunate in that we have now provided for us the best means of estimating the arguments of the great champions of the two contending schools. These are Professor Eimer and Professor Weismann, who, in our judgment, in spite of the great ability of each, outrage common-sense in opposite directions, so that a gain to the cause of truth may reasonably be anticipated from the vigorous conflict they have entered upon.

Opportunity of assisting at this combat has just been afforded us by the work referred to at the head of this review. The excellent translation of Professor Eimer's speculations, for which we are indebted to Mr. Cunningham, follows very appropriately on the translation of Professor Weismann's Essays which was published the year before by the Clarendon Press.

No one now holds a more conspicuous position in the world of biological science than does Professor Weismann of Freiburg, who has startled the world by some very strange doctrines. Thus he teaches us that there is really no such thing as a distinction of sex; such seeming difference as we do find having been developed in order to introduce a little pleasing variety into a too monotonous world. He also tells us that no animal, whether a hyena or a tapeworm, lives for itself, but for the benefit of posterity, each creature only dying in order to benefit its race; so that every organism, from a wheel-animalcule to a whale, is, unknowingly, a sort of zoological Marcus Curtius.

But this state of things is, according to him, a modern improvement, seeing that the first organisms were all potentially immortal. They were creatures which each consisted of only one cell, that multiplied by dividing into two 
equal halves, whereof each moiety had an equal right to declare itself to be the continuation of the original undivided whole. As countless myriads of such unicellular organisms still exist, we still dwell amidst immortals. Thus, according to Weismann, the life of the whole human race has no appreciable duration compared with that of the simplest animalcule of the nearest pond. Such an animalcule had already lived for a practical eternity at a time when Labyrinthodonts first began to wallow in the swamps of those primeval forests which now constitute our coal-beds. The animalcule is the Wandering Jew of biology, and even more; for he almost saw the dawn of life on this planet, and will continue his course in restless activity through the twilight of its close.

The Professor then speculates as to how death first arose by the spontaneous joining together of many such unicellular organisms to form a complex whole, followed by the voluntary starvation of some such constituents, resulting in the death of such whole. Natural death having thus once appeared, he teaches us that it was hailed with enthusiasm by nature as a cause of life. That organisms should live long enough to breed is, of course, absolutely essential for the race; but Weismann tells us that nature has been too good to allow them to live any longer, save when they could redeem themselves by some extraordinary service: Death, he tell us, has become as universal and inevitable as it now is, simply on account of the advantage accruing to those races which were relieved by it from the bane of 'useless mouths' - that is, of parents which continued to exist after their progeny had begun to breed.

Species which still continued to have many immortal individuals of such a fuseless kind-like the Struldbrugs ${ }^{1}$ of Swift-had to give way, in the struggle for existence, to races

1 In his Voyage to Laputa, c. x. 
entirely mortal, and endowed, by death, with greater health: and vigour. Those conservative 'immortals' who were so unreasonable as to decline the acquisition of a natural death were forced, by degrees, to succumb to a violent one.

But the most distinctive characteristic of Weismann's teaching is his absolute denial that any acquired characters can be inherited. No skill of hand, no activity of brain, which has been acquired through use and wont, can ever pass from sire to son. We may do much to educate the boy, but when he has grown a man, his offspring will have to begin de novo as entirely as if their parent had never opened a book or learned a line by heart.

Yet it is notorious that parental and ancestral characters. are transmitted. How is this? He tells us it is due to the fact that every creature which consists of more than one cell has a body made up of two parts: one constituting the bulk of the body (called by him the 'soma'); the other a minute portion of matter termed by him 'germ-plasm,' and supposed to retain the immortality which once belonged to the unicellular ancestor. Thus we each and all bear within us. an immortal part, living in eternal unconsciousness, and unconsciously served by fool and philosopher, peer and peasant, none of whom dreams that such service is, as it is according to Weismann, his being's one real end and aim.

But seeing that, in addition to our parents, we all have an unimaginable quantity of ancestors, how are we to explain the fact that only the characteristics of a very few of them seem to be transmitted? This he explains by a most amusing piece of pure and gratuitous assumption.

The eggs of most animals successively expel from their substance two particles, known as the first and second 'polar bodies.' These he finds, in the depth of his own consciousness, to be of quite different natures. The first, he tells us, is superfluous material, fit for building up the egg itself. 
The second he affirms to be a similarly superfluous quantity of ancestral germ-plasm. We learn from him that, as generation succeeds to generation, an ever-increasing competition takes place between such ancestral germ-plasms, the most ancient becoming gradually 'crowded out.' Thus we may imagine that, with the extrusion of a second polar body to-day, there may be excluded the germ-plasm of a contemporary of Boadicea, or of one who fought at Hastings or Agincourt, Worcester, or Waterloo, as the case may be. We may imagine this and a great deal more; but when we ask for any evidence on which such hypothesis may be seen to securely repose, we ask what we most certainly do not get. There is, no doubt, a method in the Professor's madness, but it is madness all the same.

It is time for us now to turn from the dreamer of Freiburg to consider the teaching of the visionary of Tübingen, whose work it is the purpose of this essay to review. It has been necessary to give some account here of Weismann's views, because without a knowledge of them we could not appreciate, or even really understand, the drift and meaning of Professor Eimer's book. Its avowed purpose is to review the newest evolutionary theories, and especially to deal with the laws of growth and the question whether or not any acquired characters can, under any circumstances, be inherited.

But before considering the words of Professor Eimer himself, we desire to call attention to some noteworthy remarks of his translator on the same subject.

According to Weismann, every character possessed by every animal is due to the preservation in the struggle for life of minute accidental variations in the molecular structure of germ-plasm, which alone has adapted every being to its environment. But Mr. Cunningham is prepared to maintain not only that many structural features can be 
pointed out which are not useful to their possessors, but also that all adaptations are due to the inheritance of acquired characters.

'What,' he asks, 'is the use of the coiling of the shell and the torsion of the organs in the greater number of Gasteropods? Professor Lankester has admitted recently, in the pages of Nature, that he has been teaching for many years that this torsion was due to a mechanical cause, namely, the weight of the shell over to one side, without realising that the explanation was Lamarckian. ${ }^{1}$ Now that it has been pointed out to him that such an explanation is inconsistent with the theory of Natural Selection, he admits that he can find no explanation of the phenomenon which would be consistent with that theory.'

We may, indeed, ask with him what is the use of that scrotal character whereby various mammalia differ from all other animals? What is the use of phosphorescence to pelagic animals? What is the use of that fragility of Ophiurid star-fishes which has gained them the name of brittle-stars? A great deal has been said about the utility of the colour of flat fishes; but the soles in aquaria are nearly always buried in the sand on which they live; they come out mostly at night, when, to our eyes at least, no colours can be distinguished: and when they move about by day, they are almost always covered with a thin layer of sand sprinkled over their upper sides, by which their colour is concealed.

But what can be the good of the white colour of the lower side? This is usually concealed, and when by their rising to feed it is displayed, they thereby become conspicuous to their enemies.

A powerful argument against Weismann's view may be

1 Lamarck taught that new powers and structures were due to the inheritance of modifications induced by circumstances in parent organisms. This is, of course, deadly heresy in the eyes of Weismann, while in those of Eimer it is the first article of the orthodox faith. 
drawn from the phenomena presented by the eyes of flat fishes, and this is brought forward by Mr. Cunningham in support of his, and Eimer's, Neo-Lamarckism. The very same argument was, indeed, brought forward by us twenty years ago. ${ }^{1}$ Flat fishes (that is, such fishes as the sole, flounder, brill, turbot, etc.) when young, have the eyes situated as usual, i.e. one on each side. As they become adult, however, one passes over, so that both eyes come to be upon one side (right or left) of the head. This could not have been brought about by the minute changes of natural selection, since the mere transit of the eye for a small fraction of its ultimate journey could never have been the means of saving a life. This is the more evident since in the young turbot and brill the metamorphosis is very nearly or quite completed long before the little fish have retired to the seabottom.

Mr. Cunningham well observes :- 2

'Nothing can test better the claims of the two theories-the NeoLamarckian and the Neo-Darwinian ${ }^{3}$ - to be accepted in explanation of the origin of adaptations than the case of the woodpecker. This bird lives entirely on insects, and only catches insects in one way-a very peculiar way. It probes the holes in the bark of trees made by insects, or makes holes itself, and then inserts its long, pointed tongne, whose tip is provided with recurved papillæ, like a narrow bottlebrush, and with this extracts the maggots. The rapid protrusion of the tongue to a considerable distance, and its sudden retraction, are rendered possible by the elongation of the processes of the hyoid bone, to which the tongue is attached. These processes are bent upwards and forwards over the back of the skull, and inserted near the orkits. Now, in all birds the tongue is attached to the hyoid bone, and moved by the muscles connected with it; in nearly all birds the tongue is

1 See The Genesis of Species, p. 41.

2 Page xvi.

3 The term 'Neo-Darwinian' is applied to Professor Weismann and to each of his supporters, in spite of the fact that he to whom they appeal would have repudiated them. The epithet 'Neo-Lamarckian' is given to those who sympathise with Professor Eimer. 


\section{4}

muscular and mobile. It is admitted even by Weismann's adherents that the size and shape of bones, the size and shape of muscles, are in the individual modified by the use which is made of them. It will also probably be admitted that the modification is such as to facilitate the operations in which they are used. Therefore, in every generation of woodpeckers-which birds, in the struggle for existence, had to be content to pick up a living on tree-trunks, or starve-the constant use of the tongue in extracting insects from holes in trees must have elongated the tongue and hyoid bone, and increased the power of protrusion of the organ in each individual. The Neo-Lamarckians believe that these individual modifications were inherited in some degree, so that a greater modification in the same direction was produced in the offspring, and in this way it is easy to understand how the degree of specialisation we now see was produced.

'The Neo-Darwinians say that it is quite true that such modifications were produced by functional activity in the individuals, but these modifications were never inherited; other modifications of the same kind arose by congenital [purely accidental] variation in some of the same individuals, and the individuals that had these survived; and then the favoured individuals pairing together, some of their offspring, inheriting from both parents, had the modification in a greater degree, and so on; which is very much like the argument that the Iliad and the Odyssey were not written by Homer, but by another man of the same name who lived at the same time. . . Selection, whether natural or artificial, is perfectly analogous to the process of denudation in geology. It explains the extinction of innumerable forms and the consequent gaps and intervals which separate species, families, orders, etc., just as denudation explains the want of continuity in the stratified rocks. But geologists have never been blind enough to suppose that the evolution of the structure of a given rock was due to denudation; they have always believed that the structure of each rock was due to the effects of the forces which have acted upon it since its formation, and they have devoted their energies to tracing by observation and experiment the effects of the various forces.'

The fact is, both the Neo-Lamarckian and Neo-Darwinian theories are potent in attack, but impotent in defence. In order to have a rational conception of nature, we need a tertium quid to give solidity to the elements of truth they 
each contain: this it will be our business, later on, to endeavour to point out.

It is most true, as Mr. Cunningham says, that Professor Weismann's view of heredity is not, as he seems to think, in any sense an explanation. Whether the reappearance in offspring of characteristics possessed by parents be due to any influence of a parental organism, or merely to a fixed tendency in germ-plasm, it remains in either case equally and absolutely unexplained. The use made of the word 'heredity' often shows that our contemporaries are as ready as were any of their forefathers to rest content with mere words and phrases. The term 'heredity' merely serves to denote the fact that characters remain constant, within narrow limits, through succeeding generations.

The persistence of characters implied by heredity is as mysterious as, and no more so than, the process of change which external conditions may induce.

' Everybody knows that in a given district, even on a given farm, certain varieties of animals and plants cannot be produced in perfection. Individuals may be procured, the most perfect in existence, but in a particular district or on a particular farm they do not "thrive"; that is to say, the qualities for which they are valued disappear in the individuals, or, as is more often the case, in a few generations, in spite of all care and selection, . . . there is evidence that physiological change precedes morphological. There is a climbing kangaroo in Papua which shows so little adaptation of structure to the climbing habit that no naturalist would believe from the mere study of its body that it lived in trees. But, as a matter of fact it does live entirely in trees.'

Professor Eimer's work consists of eight chapters, referring respectively to the following subjects. In the first we have a brief exposition of the newest theories concerning Evolution. The second treats of 'the organic growth of the living world.' The third deals with the 'influence of adaptation in the formation of species.' The fourth is 
devoted to a consideration of acquired characters. The fifth describes what the author believes to be the effects of the disuse of organs and of indiscriminate breeding. In the sixth, 'mental faculties as acquired and inherited characters' are considered. The seventh chapter treats of the 'evolution of the living world as the result of function'; and in the eighth and last, an examination of 'the idea of Organic Growth' leads to his conclusion.

Before examining these chapters seriatim, it may be well -in order to make plain what is the mental standpoint from which he has set forth to contemplate the living world about him-if we begin with an examination of his 'conclusion.'

- We shall thus also be enabled to gain a fuller knowledge of this 'standpoint' if we likewise briefly review a popular lecture of his, here given as an appendix, and entitled, 'On the Idea of the Individual in the Animal Kingdom.'

The conclusion at which he arrives ${ }^{1}$ may be thus summarised. One principle of unity runs through the whole organic world, and is essentially the same in the vital manifestations of the lowest alga and the highest reflections of the mind of man. Any one, he tells us, who completely renders allegiance to his doctrine and

' rejects everything which contradiets this principle, cannot help admitting that in truth, as I [Eimer] assert, the ultimate origin of the various kinships in the animal and vegetable kingdom is to be traced to individual differences, and that the differences between the former, like the latter, must be essentially determined by external conditions, by the modifications of organic growth.'

Thus we have given us the keynote of the symphony to which we will shortly give an ear. One expression of Professor Eimer's, however, must by no means be passed over. He tells us ${ }^{2}$ it is a 'self-evident truth' that 'if species are only a collection of individuals, and genera a P. 409 .

2 P. 410. The italics are ours. 
collection of species, families only a collection of genera, and so on, ... then ... the causes which modify an individual within the boundaries of a species must be the same as those which modify it beyond these boundaries.'

Here is, indeed, a sentence worthy of being long pondered over and carefully analysed. Truly it is a most precious morsel; for it shows clearly what is the real value of much seemingly profound teaching both of the Neo-Lamarckian and Neo-Darwinian schools. The unfortunate general public, who take a ready and laudable interest in natural history, are seized upon by erudite professors, who, with solemn admonition or playful banter, discourse to them on subjects of which they, the said professors, are profoundly ignorant. Yet they are believed to know all about it on the strength of their unquestionable proficiency in physical science. On this subject it is time to speak plainly: Physical science is admirable and useful, and men of physical science fully deserve our respect and recognition. Nevertheless, a great deal too much fuss is now made about it. Men of science themselves know well enough that to dissect, to become familiar with the different bodily structures, to use the microscope dexterously, etc., require a certain readiness and perseverance. But they also know quite well that these are, after all, mechanical arts, and no more. Men of science themselves also know well enough that to obtain a wide and firm grasp of their subject; to be well aware of what has been done by their predecessors and is now being elaborated by their contemporaries; to reason accurately from facts observed to the probabilities concerning other facts as yet unobserved; they know that these things need a certain quickness and flexibility of mind and a considerable power of memory. But they also know quite well that such quickness, flexibility, and power need be in no way exceptional, and that the very same qualities must be 
possessed by any true classical scholar, and certainly by any successful statesman. As Cicero. wondered how two augurs could ever meet without laughing, so we wonder how experts in merely physical science can sit with grave faces and listen to the exaggerated praises and unmerited professions of exceptional veneration which are now so commonly uttered in their presence on festive occasionstoo often by timid Churchmen who little know their own strength and the real feebleness of those before whom they tremble.

But to return to the sentence which called forth these remarks. Eimer says: 'Species are only a collection of individuals, and genera a collection of species.' But certainly he would not (no naturalist could) deny that 'individuals' are really existing things-substantial, material entities in rerum natura. Yet no less certainly he must deny that 'species' are anything of the kind. He may have in his cabinet few or many 'individuals' of any given 'species,' but we utterly defy him to place there a 'species' either impaled with an insect-pin or preserved in a bottle of alcohol. Species, genera, families, etc., are ideal entities; real in so far as their essential characters may be exemplified in really subsisting things, but in themselves they are mental conceptions-essential, ideal, and immaterial. We claim to be very earnest realists ourselves, but most certainly we should never think of locking up the 'species' horse in our stable, or trusting ourselves to its guidance over moor and field.

In this passage Eimer has hopelessly and inost obtusely confounded not only two distinct things, but two things of quite opposite natures. A man who has given forth such a statement has thereby proclaimed himself to be one who is absolutely unfit to teach.

With this clue to the intellectual calibre of our professor, 
we may be enabled to estimate the value of his 'idea of the individual in the animal kingdom,' as portrayed in his address delivered at the Fifth Congress of German Naturalists.

It is but too probable that very many of those naturalists were not in the habit of frequenting any place of worship, and thus a discourse smacking so strongly of the language of the conventicle may have had enough charm of novelty for them to enable them to sit it out.

The discourse is, indeed, brim-full of unction, and begins with a solemnity distant but 'one step' from the sublime :-

'Man loves to isolate himself from Nature.

' $\mathrm{He}$ is reluctant to confess his kinship with beings which he thinks beneath him.

' He alone will be lord, alone wise; he the crown of creation.

'But who gives him the right to assume this pre-eminence?

'How small is his power!

'Man the mighty is powerless against the infinitesimal organisms which seek to enter his blood and destroy him.

'A wave kills him, while the ocean is teeming with life that mocks his sovereignty,' etc., etc.

We can only speak for ourselves, and we only claim to be one of the crowd-the man in the next street,- - but we are quite sure we do not love to 'isolate ourselves.' Nor are we in the least ashamed of what we have in common with the beasts and birds, insects and creeping things about us. Nevertheless we are firmly convinced that we possess an intellectual power which such things have not. Nor do we see how the chance of our being poisoned by a parasite, or knocked down by a wave, in the least militates against our mental superiority to the parasite or to any living thing which may be within the wave which buffets us.

He then proceeds to carry out his purpose, which, he tells us, ${ }^{1}$ is 'to attack the apparent independence of the animal

1 P. 415. 
organism which is implied in the word individual,' and 'to prove that the conception of an indivisible entity is unable to withstand a more exact investigation.'

In support of his proof he begins by affirming that animals have been declared to differ from plants in that no part can be separated without injury to the whole-a belief he affirms to have been connected with, and to be indispensable to, the doctrine 'that the animal as distinguished from the plant possesses an indivisible soul.' We do not know any one who has 'declared' this ; certainly no such declaration has, so far as we know, been made by any writer of authority or reputation.

The old doctrine of Aristotle and the schoolmen, to which we suppose Professor Eimer refers, was that every plant, like every animal, has indeed a 'soul' (by which was meant what we should call a dynamic principle of individuation), but that the divisibility or non-divisibility of such plant or animal depended on the material organism informed by that soul, which is simple common-sense. The experiments of Trembley, Bonnet, and others no doubt excited astonishment in the last century; but that was because the men of that age had left far behind them and ignorantly despised that Aristotelian teaching with which the most recent advances of physiology have so fully concurred. We recollect that, when quite a youth, Sir Richard Owen once said to us at the College of Surgeons, 'I do not think that, in matters of philosophy, the human mind will ever get much beyond Aristotle.' We have grown to be very much of his opinion.

Now there is no reason whatever why ordinary men should trouble themselves with the study of philosophy. There are, indeed, wide fields for the intellect to do good work in, without that, especially within the domain of physical science. But when a devotee of physical science, merely on the strength of his physical knowledge, goes on to preach 
metaphysical doctrines, he is stultifying himself, and runs a risk of stultifying his hearers also. But this is just what such men as Eimer, Weismann, Haeckel, etc., are always doing, and the lecture which terminates Professor Eimer's book is a forcible example of the kind. He objects ${ }^{1}$ strongly enough to Nägeli's attempt to confine biological speculation to 'physiologists by profession.' We sympathise with him in his protest against 'such a close corporation,' and we have no wish to confine speculation to 'philosophers by profession'; but what we do affirm is that some preliminary knowledge of philosophy is necessary for any one who would not only speculate, but also teach it.

On the strength of the familiar facts that all animals feed and get rid of effete material, and that they can, in varying degrees, endure a certain amount of mutilation, he argues ${ }^{2}$ that there are really no individuals at all, and that the entire animal world forms one whole, wherein what are commonly regarded as individuals are but so many 'organs.' On the very same system it is quite possible to maintain that animals and vegetables together form one being, or that such is the case with the whole mass of our planet, or of the solar system, or of the whole sidereal universe.

Dreams such as these are possible enough, and visionary professors may go about preaching them, but plain men will remain quite as certain as before that their individual existence is unaffected by the fact that they can have their hair cut with impunity. Nor will they be persuaded that they, together with their dogs and horses, are but so many mere organs of another individual, and they will be as certain of this as they are sure that they are individually distinct from the plants in their conservatory, or the stars over their heads.

But Professor Eimer's real end and aim is shown by his 1 P. 53.

2 P. 433. 
conclusion. $\mathrm{He}$ is one of those whose great object it is to try and persuade themselves and others that they are not what we mean by 'men,' but mere 'irrational animals,' free from the rule of any Higher Being here, and free also from any responsibility for their actions hereafter. It would be wonderful and inexplicable that any one should be animated by such a passion for self-degradation, did we not know how strongly many a man may be tempted to feel 'Lord of himself, that heritage of woe.' Few things seem unwelcome to such persons, if only they can escape the dreaded need of being called on to adore, obey, and serve.

'Good,' Eimer tells us, ${ }^{1}$ ' is not something prescribed from without; we call only this the good which is serviceable to the common well-being, and because it has become serviceable to the common well-being.'

This amounts to a denial that there is such a thing as 'goodness' at all.

Of course, concomitantly with the degradation of his own species, he treats us to that exaggeration of the psychical powers of mere animals which is a characteristic of the school to which he belongs, and which, as we shall see, has a tendency as fatal to freedom as to intellectual life.

Thus, as to the 'Mental Life of a Bee,' he affirms- 2

' that it shows reason in a high degree. The animals act throughout according to the requirements of a well-organised State in various directions. They act in complete accordance with the common interest of all the single members of the State, and with the requirements of the future. It is true that it seems to the observer as if this action was in many cases mechanical, as if the animal's conduct was in particular instances not the direct result of mental reasoning, but as if they performed reasonable actions mechanically. But in other instances we are compelled to admit that, after fully considering the particular circumstances, they do what is best for the future and for the common weal. If we suppose, for example, that the collec-

${ }^{1}$ P. 434.

2 P. 424. The italics are ours throughout. 


\section{Eimer on Growth and Inheritance}

tion of honey has become mechanical, that the bees no longer reason consciously in performing this labour, yet we must assume that originally they began to collect honey from reflection and reasoning; for otherwise they would never have come to do so mechanically.'

The application of his principles speedily follows. He lays it down ${ }^{1}$ that the system he advocates-his ideal-

' is the most uncompromising opponent of that confused idea of freedom so injurious to the common good which claims unlimited independence for the individual.'

' Unlimited independence' is, of course, absurd and impossible, but his ideal is in reality no less hostile to limited freedom also, and would reduce the rational human being to a mere animated machine. He continues :-

'It [his ideal] takes in some sense the social life of the bees for its model, in which the work of the individual for the community has become automatic action.'

This would indeed be a glorious prospect for mankinda truly noble goal to strive after: to become a crowd of automata, utterly devoid of both intelligence and goodwill; but co-operating and interacting so as to nourish themselves and breed most effectively. The last rudiments of intelligence or benevolence having been annihilated by an ever-increasing complexity of mere reflex action, the social machine working with continually-increasing efficiency may persist till the inevitable annihilation, to be produced by the gradual dissipation of energy, puts a final end (none too soon) to the whole mass of most efficiently co-operating idiots.

We have so recently considered ${ }^{2}$ the question of the essential difference of kind which exists between the mind of

1 P. 434.

2 See ante, pp. 289-314, also the Edinburgh Review for October 1889, on the 'Origin of the Intellect,' especially pp. 359-372. Since the publication of that article we have published a work entitled, The Origin of Human Reason, wherein the distinctions to which we have briefly adverted are brought out distinctly and at full length.

VOL. II. 
man and the highest faculties of any other animal, that we forbear to say more upon that subject now. Assuming that our readers have grasped the profound distinction which exists between our own higher and lower faculties (a distinction which well enables us to understand the so-called intelligence of animals, and especially the difference between intellectual sign-making-whether by sounds or gesturesand merely emotional language), we will now proceed to make the few remarks which seem to us necessary upon the different chapters of Professor Eimer's book.

His first chapter is deroted to a statement of those doctrines of Weismann which have been described by us in the beginning of this article, with an account of the speculations of another theorist-Nägeli-whose notion is that the whole organic world develops and grows by an internal force, as does an ordinary tree. To this innate power he ascribes the different directions in which organisms vary, and the first commencements of new structures, matters for which Darwinism is, as was long ago pointed out, impotent to account. The action of natural selection can, according to Nägeli, be no more than that of a gardener's pruning-knife-an illustration before made use of by ourselves.

In his second chapter, on 'The Organic Growth of the Living World,' Eimer states his somewhat singular theory as to the true cause of the origin of species, which he attributes to the lagging behind of certain individuals in that rate of organic change which surrounding influences impress upon their fellows.

'We have before us,' he says, ${ }^{1}$-' a graduated evolution, and the essential cause of the separation of species is seen to be the persistence of a number of individuals at a definite lower grade of this evolution while the rest advance further in modification. This mode of origin of varieties or species, as the case may be, I have named Genepistasis

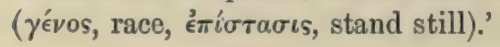


He strongly combats the idea that mere utility will account for the characters of organisms, and pertinently remarks :- ${ }^{1}$

' There can be nothing indeed more splendid in colour than the iridescence of Labradorite, and is this useful to the stone, and are colour and brightness useful to gold and countless other minerals? Are they useful to the soap-bubble?'

In stating his views as to the influence of fathers and mothers, respectively, on their families, he makes some interesting remarks concerning what he believes to be the gradual extension of dark hair and eyes amongst the Germanic races. He says :- ${ }^{2}$

' Dark and fair parents together do not usually produce children which in colour are intermediate between them, but fair and dark again. Dark, however, according to my observations, has a preponderance over fair. When it is once there it is not easily eradicated from the blood. . . . The length of time for which the dark and the blond type can constantly recur separately in the children of light and dark complexioned parents is particularly well shown by several South German villages, like those in the immediate neighbourhood of Tübingen, where a thoroughly dark, almost Romance, and a purely Germanic race of people appear often enough sharply distinguished in the children of one and the same family-notwithstanding the fact that in these little villages, intermixture is continually taking place, for the people usually marry among one another, and seldom outside the village. . . . That darkness of hair and eyes is, among us, something newly ingrafted, and is on the increase, is proved by the universally known fact that the children of dark German parents are, as a rule, in the earlier years of life, fair, and have blue or grey eyes; here also characters which were dominant in the ancestors are repeated in youth. This biogenetic fact struck me first, and very forcibly, in the Upper Engadine, where obviously an intermixture of blonde Germans with dark Romans has taken place, and where it is the more surprising because the climate in that region would favour rather lightness of colour. For example, in the neighbourhood of SilsMaria, in villages where the adults are all perfectly Romance in

$$
{ }^{1} \text { P. } 34 .
$$$$
2 \text { P. } 36 .
$$ 
darkness of complexion, one sees children of such dark parents with quite fair flaxen hair and blue eyes.'

Professor Eimer is a strong believer in the predominant influence of the male parent. He regards this as at once the cause of, and proved by, the fact that we are often able to recognise family characteristics in pictures of the earliest male ancestors to be found in galleries of family portraits.

'If this prepotency of the male did not exist, if the female element in all unions had exactly the same value as the male, then, after comparatively few generations, all similarity to ancestors, excluding cases of one-sided reversion, would be completely effaced.'

He adduces as palpable evidence of the truth of his view the long persistence of the well-known Habsburg lip.

'Portraits of Rudolf r. of Habsburg,' he tells us, ' 'already show it. It was inherited by his descendants up till the last of them, the Emperor Charles vi. (1740) - that is, for five hundred years. With Charles vi. the male line of the Habsburgers became extinct. Its place was supplied by the Thuringian line, derived from the marriage of Francis of Thuringia with the Habsburger Maria Theresa. In the male descendants of this couple the great under-lip appeared again, and has been transmitted up to the present day, although the wives of the Habsburgers, coming from various families, could not possibly have possessed it by chance, and did not possess it.'

These remarks about parental influences lead on to a criticism of Kölliker's theory of evolution. According to that naturalist it is the egg, and not the adult organism, which produces new forms of life. He conceives that the seminal principles of creatures thus give rise to new varieties and species through the stimulus of external conditions acting upon internal causes. These internal causes, however, he regards as being nothing essentially vital, but as the merely physical and chemical conditions in which any organismsor, rather, the reproductive parts of organisms-happen to find themselves. Kölliker's view is judged ${ }^{2}$ by Eimer to be

$$
{ }^{3} \text { P. } 4 \text { ? }{ }^{2} \text { P. } 51 .
$$


no more supported by facts than some other propositions of his, and to rest, in fact, upon nothing but assumptions concerning mere possibilities. To us, however, it appears clear that every one of the various hypotheses hitherto proposed is manifestly insufficient to account for the facts. For Kölliker's theory, as for Eimer's, Weismann's, and Nägeli's, there is required, besides some actual evidence, a further intellectual conception to make it even thinkable-a matter we shall have occasion to indicate more fully in the course of this review.

In his third section he brings out his own views more distinctly, corroborating the view of Weismann that every structure is a useful adaptation which has been brought about by natural selection acting in accidental infinitesimal changes in germ-plasm. At first sight it would seem that he advocates the action of some distinctive vital power, but this he categorically denies.

'I repudiate,' he declares, ${ }^{1}$ 'any special internal force of evolution. According to my view, everything in evolution is due to . . . material, physical causes, ... a "crystallisation," resulting from the physical and chemical action of external agents on the material of the organism subjected to them.'

This idea we will consider presently; for the present we will limit our attention to his opposition to Weismann's views as to the distinction between unicellular and multicellular animals with respect to immortality. He would place some limits to the immortality of the former on account of their 'metabolism' - that is, the constant minute changes in their structure which are inseparable from life. As to multicellular organisms, he admits the mortality of the general substance of their body-their soma-because 'the latter is not really an end in itself.' But, as his translator, Mr. Cunningham, very pertinently observes: 'It would be 
just as true to say that the germ cells are not an end in themselves, but serve only to produce the soma.' In spite of this obvious slip, Professor Eimer has good reason on his side when he says that we have as much right to predicate immortality of many of the multicellular animals as of those which are unicellular. It often happens that sea-anemones which have been well fed will spontaneously bisect themselves. This process will occur again and again, and seeing that some of them can live at least sixty years without it, it is quite impossible to deny immortality to them if, on similar grounds, we attribute it to the lowest organisms.

As an example of characters which have been developed independently of any 'natural or sexual selection,' Eimer adduces ${ }^{1}$ the markings of certain garden snails.

'The striping,' he observes, 'might be regarded as an ornament which acted as an advantage in sexual selection, but such an assumption is inconsistent with the following facts. I have observed for years in my garden that striped and unstriped individuals of Helix hortensis unite without any selection; and what makes this case particularly noteworthy as a support for my view of the comparatively slight effect of sexual crossing in the production of intermediate forms (one-sided heredity) is this, that the offspring of these striped and unstriped parents are again striped or unstriped-in spite of constant crossing (panmixis) these two forms appear everywhere side by side, with no connecting forms between them.'

That some kind of internal force-though not ' a special force of evolution'-regulates the efflorescence of new characters is fully affirmed by Eimer, and this conclusion he deems supported by phenomena to be observed in caterpillars, which have not only a tendency to repeat the same markings in their successive segments, but to exhibit them at an earlier and earlier age, although no advantage to them appears thence to arise. He also cites ${ }^{2}$ an earlier utterance of Weismann himiself in the same sense, and yet the position
${ }^{1}$ P. 75.
2 P. 73. 


\section{Eimer on Growth and Inheritance}

they both assume is avowedly antagonistic thereto. Truly we may urge on the attention of both these naturalists the Tübingen Professor's own words:1 'If we philosophise about nature at all, the naturalist who desires to be thorough must not halt half way.'

In his fourth chapter our author applies himself to the main question - that of the transmission of characters acquired by parents. Very curious effects on organisms may sometimes be produced, which cannot be considered as resulting from any inherited capacity, since structures are developed which the parent organisms never possessed. The following ${ }^{2}$ is one example :-

'Very pretty experiments 'in relation to this point have been made by Fraulein Von Chauvin upon the Alpine salamander, Salamandra atra. The gill-bearing larvæ of this animal were taken out of the oviduct of the mother and put into water. It is well known that these larvæ under the usual conditions at a later time, while still within the mother's body, lose their gills, and, what is very rare among amphibians, are born as completely terrestrial animals. The gills of the larvæ placed in water at so early an age were disproportionately large and hindered the animals in their movements, and in some cases they were cast off, whereupon new smaller organs arose in their place. These new gills persisted in one case for a surprisingly long time (fourteen weeks), and then atrophied. This larva, like the rest, ultimately developed into a land animal. But the remarkable fact remains that on account of the peeuliar conditions of life artificially produced, after the original gills, which were unadapted for use in a free state of life, had perished, new and suitable gills were formed, not in the struggle for existence against competitors with the cumulative effect of selection, but, as I believe, directly from purely physiological causes.'

As to acquired characters which are due to direct external action, he brings forward many interesting examples concerning the relation of colour in organisms to the light to which they may be exposed. The green colour of plants

$$
\text { P. } 70 .
$$

P. 81. 
cannot be said to be an inherited one in spite of the millions of generations of vegetable organisms which have all possessed that tint; because when young plants are reared in the dark they remain colourless. ${ }^{1}$

'The profound action of light on the whole physical constitution of the plant body, on the whole physiology of plants, is shown by the fast that many tropical plants-as, for example, the South Americin species of Bougainvillea, in European hothouses either do not bloom at all, or only incompletely, in spite of all application of warmth, on account of the deficiency of light.'

Various kinds of tropical plants die in our botanic gardens in the Regent's Park when we have a succession of such days of overhead darkness as now and then occur in London. No amount of warmth supplied to them will enable them to escape the fatal consequences of such darkness. An instructive example is found amongst animals in the case of the Proteus of the caverns of Carniola and Istria. This animal is at first colourless, but if it be kept in the light it becomes coloured. ${ }^{2}$

The effects of climate on cultivated plants have been well shown by P. C. Schübeler with respect to those of Scandinavia. When various cereals in Norway and Sweden are gradually transported from the plains to mountain districts, they can be accustomed not only to develop in the same or even in a shorter time than in their native region, but even at a lower average temperature!

When such grain, after it has been grown for several years in the mountain regions, is again sown in its native soil, it ripens at first earlier than other grain of the same kind which has been cultivated uninterruptedly in the plains.

With respect to a variety of phenomena of this kind Professor Eimer observes:- 3

'It is a proposition of special importance to my argument, as well
${ }^{1}$ P. 90.
2 P. 144.
3.Pp. 95, 96. 
as in itself self-evident, that physiological changes must always precede morphological changes of structure in the organic world, because the former determines the latter.'

The significance of this, taken in conjunction with other assertions, will appear later on.

In considering the effeets of temperature, some interesting facts noticed by Dorfmeister are described. ${ }^{1}$ This observer has

'ever since 1845 made experiments on the effect of temperature in the colour and marking of butterflies. He explains first of all that through many years' experience in rearing caterpillars, he has been convinced that the production of varieties of butterflies depends much more on climatic conditions, in which temperature is a chief factor, than on either food or hybridisation. Dorfmeister learns from his experiments that temperature exercises the greatest influence on the colour and markings of butterflies when it acts upon them during the change into the pupa, or shortly afterwards. In many, a rise of temperature produces a lighter, more brilliant ground colour, a fall a darker or less brilliant; for example in Vanessa, Io, Utricæ, etc. In Eupressia Caja the red-yellow ground colour of the posterior wings is changed by a rise of temperature into vermilion-red; by a fall, into ochre-yellows'

The specially stimulating effects of surrounding colours is very curious, and has been well worked out by Mr. Poulton of Oxford. As Eimer says, pupæ have assumed the red colour of a cloth investing them, a colour to which they could scarcely be exposed under natural conditions, and to which in any case they could not have been adapted by selection. Well may he say, "Many really wonderful cases of adaptation, apparently due to selection, probably come 'under this category,' a category including such cases as the common frog, which changes its hue according to the colour of the ground, not rapidly, but gradually.

The power the frog has of thus changing was experi(mentally ascertained by the Professor :-

1 P. 131.

${ }^{2}$ P. 144. 
'Three frogs' (he tells ${ }^{1}$ us) 'approximately similar in colour, were placed in three vessels, of which the first stood on a black, the second on a green, and the third on a white surface, being surrounded to the height of some five centimetres with the same colour.

'After about an hour and a half, the frog $a$ on the black surface was the darkest, $b$ on the white the lightest, while the frog $c$ surrounded by green was intermediate in colour between the two. Hereupon the frog $a$ was transferred to the glass on the white, frog $b$ into the one on the black surface. After three-quarters of an hour they were again examined, and $a$ was the lightest, $b$ the darkest. Then $c$ and $b$ were interchanged, and in a quarter of an hour $c$ was the darkest, while $b$ was intermediate in colour between $c$ and $a$. When, finally, $b$ and $a$ were interchanged, a change of colouring appeared immediately; $b$ became light again, and $a$ took the intermediate tint between $b$ and $c$. '

With regard to the inheritance of injuries, the work supplies us with some valuable facts. In the first place its translator severely criticises what he regards as a great misrepresentation made by Professor Weismann of a case adduced by Dr. Emil Schmidt, and regarded by the latter as a plain instance of the inheritance by a son of a malformation in the ear, due to his mother having had her earring accidently torn out when a child. ${ }^{2}$ But Dr. Meissan, of Falkenberg, has recorded ${ }^{3}$ the following case of injury in his own family :-

'When I was seven or eight years old I had the chicken-pox, and I recollect with complete distinctness that I scratched one of the pustules on the right temple, in consequence of which I had a small white scar on this spot. Exactly the same scar, which I had of course ceased to think of, on exactly the same spot, was present on my little son, now fifteen months old, when he came into the world. The resemblance is so perfect that it surprises every one who sees the little mark.'

Dr. Eimer's assistant, Dr. Vosseler, relates that his mother in her eighteenth year injured the ring finger of her right hand by squeezing it between the door latch and the door,

${ }^{1}$ P. 148. $\quad{ }^{2} \mathrm{Pp}$. viii to $\mathrm{x} . \quad{ }^{3}$ In the number of Humboldt for June 1887. 
so that it was bent between the last and middle joints. Two of her sons were born with the very same peculiarity, and Dr. Vosseler was one of them.

It may be a relief to some of our readers to turn from these questions to our author's remarks concerning the higher faculties of animals. His whole contention is indeed vitiated by his non-comprehension of his own higher faculties; but that does not hinder his anecdotes from being amusing, nor is there any danger of our being misled by them if only such facts and laws as we have elsewhere called attention to be duly borne in mind. That Professor Eimer does indeed misunderstand his own higher powers is plainly shown by his definition of consciousness. ' By conscionsness,' he tells us, ${ }^{1}$ 'I understand the sensation of the condition, as affected by the outer world, of the brain at the moment.' As if 'consciousness' and 'sensation' were not widely different; and as if we could not be perfectly, intensely conscious without even believing that either a 'brain' or 'an outer world' existed. We leave Professor Eimer to settle this matter with the idealists.

Here, also, he reiterates that sad confusion between the abstract and the concrete-the ideal and the real-which we before stigmatised. No wonder that he confounds the intellectual state we call 'consciousness' with a 'feeling about the condition of the brain'!

'It is certain,' he exclaims, ${ }^{2}$ 'that rigidly logical reasoning' must necessarily admit the conception that individuals are organs; and species and genera, by virtue of their definite structure adapted to definite ends, are organs of a higher order of the whole living world.' This is just as if he said that a cannon was a weapon, and that an implement of war was a weapon of a higher order !

Such errors, however, in no way impair his credit as a ${ }^{1}$ P. 223.

2 P. 225. 
careful observer of interesting natural facts. They only do away with the value of his explanations of them. We should be the last to deny to animals the keenest powers of perception, and so great a facility for associating past experiences, feelings and emotions, as to make their powers of practical inference obvious. What we deny to them is a power of reflection, and the conscious possession of ideas as such. We deny them the power of forming true abstract ideas, and therefore of expressing such ideas in abstract language. But no reasonable person would think of denying that many of them possess a rich and copious language of feeling. As to their sentiments of fear and confidence being modified by circumstances, he tells us ${ }^{1}$ the following anecdote:-

'Some years ago a male chaffinch in my garden had become so tame with me that he flew after me everywhere, in order to take the hemp-seed and meal-worms which I offered him. Wherever I went or stood in the garden the finch appeared from the bushes, perched on the nearest branch or on the ground in front of me, and with his powerful chirp-" "pink, pink"- -demanded his food. But if he had not noticed me, I had only to whistle in imitation of his chirp and he appeared. At last he used to come after me even into the house, and follow me from room to room asking to be fed. Yet, in spite of his trustfulness, I could not induce him to feed out of my hand. It was evident that he constantly endeavoured to overcome the remnant of timidity which still survived in him, but he could not yet succeed. Still I strove to attain this end, and the visible progress made permitted the hope that I should shortly succeed; then an unfortunate accident suddenly altered the condition of affairs, and put an abrupt end to his confidence. One day a sparrow on a tree in front of my window was piping indefatigably his monotonous shrill chirp, which pierces the ear the more irritatingly the more energetically it is uttered, and the greater its well-known deficiency of cadence. As the fellow had repeatedly disturbed me at my work in this way, I resolved on his destruction, and, creeping within range, I fired at him with a small chamber gun loaded with small shot. At the shot my beloved finch flew suddenly from the tree where he had been perched

1 P. 232. 
unnoticed by me. The shot must have passed around him. My sorrow for the accident was deep, for what was to be expected occurred - the finch afterwards carefully avoided me, and notwithstanding all enticements, I could only with difficulty induce him again to take from the ground at a great distance from me food which I had scattered. But after a short time he disappeared entirely from my garden with the family which he had established.'

We most of us know something of the cunning and prudence of sparrows. As to this we have the following anecdote :-

'One snowy winter recently, when the sparrows around the house were very hungry, I made an attempt to eatch a number under a large sieve, the edge of which was supported on one side by a piece of wood, which was connected with a long string; the string was covered up in the snow, and passed through an opening in the door into the house, where my little son watched, ready to pull the string as soon as some sparrows went under the sieve. Corn was strewed about under the sieve and around it as bait. The sparrows gathered in dozens round the sieve, and picked up the corn to its very edge to the last grain, then flew round and screamed at the sieve in hunger and rage, but not one was enticed under it.'

On the subject of the same caution as displayed by a dog who, after accompanying him to the shore, ran away when the Professor had undressed and entered the water, he makes some curious, not to say singularly nonsensical, remarks.

'The whole occurrence,' he tells us, ${ }^{1}$ ' gave me the impression that the dog was terrified at the appearance, to him previously unknown, of an almost unclothed and afterwards naked man, and that he did not give way to the panic from the first, before I went into the bath, because he had not yet drawn the conclusion that he had to do with a spectre. . . Fear of things incomprehensible is indeed the cause of such conceptions among men, and among many savage peoples is still at the present day clearly the cause of their belief in a higher being. It is stated that dogs do not bark at naked men, which is probably to be attributed to fear of the unknown.' 
Certain observations made by the Professor with respect to chickens newly hatched seem to us to be valuable. To some which had been artificially hatched he threw a little millet-seed, letting it fall so that the grains rebounded. The chickens at once pecked at it; but he adds : ${ }^{1}$ -

'The thing which surprised me most was this: A fly flew close by the eyes of a chicken which had only left the egg-shell about half an hour before, and the little creature pecked at it as if it had been long accustomed to catch flies. Similar cases have indeed been frequently observed. It may be objected that this was nothing but reflex action --and of course it is reflex action. ${ }^{2}$ But the wonderful fact is, that that action was so perfectly adapted to the external requirements: the chick snapped at the fly in order to catch it; it made with accuracy all the movements suited to this purpose. . . . In short, the chicken's behaviour towards the fly was a consequence of innate instinct, like that of itself and brethren towards the millet-seed.'

The merely instinctive, as opposed to intellectually purposive, actions of these chicks, was shown by their scratching on boards (which formed the first surface they walked on) just as mature fowls scratch in sand or earth in search of food.

'To see them scratching on the smooth board, from which there was nothing to scratch out, was exceeding comical.'

His view of instinct is, as before said, that it consists of truly rational actions which have become habitual, and is therefore absolutely opposed to that of Professor Weismann, who regards it as the result of merely minute accidental changes in the molecules of germ-plasm. But, as Professor Eimer pertinently asks, "How is it conceivable that the variability of germ-plasm, inherited from unicellular organisms, in combination with continued sexual mixture, could

1 P. 245.

2 The term 'reflex action' should be reserved for motor responses to stimuli which are not felt. Such reflex action as the chicken's is 'sensori motor' action.

${ }^{3}$ P. 253. 
lead to such innate faculties as our chicken has shown?' We also fully agree with him in his remarks concerning the very singular instinct of the cuckoo. He does not hesitate to declare ${ }^{1}$ that it appears to him to be $\dot{a}$ priori impossible that 'instincts can be explained by mere accidents,' and especially impossible that the young bird derived from an egg which was for the first time accidentally laid in the nest of another species should itself repeat that action-an action which, by the hypothesis, was opposed to inherited tendencies derived from countless generations of ancestors. But if Eimer sees clearly the moat in the eye of Weismann, he is none the less blind to the beam which is in his own. $\mathrm{He}$ tells ${ }^{2}$ us that he believes that the original progenitors of the cuckoo, when they first began to lay their eggs in the nests of other birds, 'acted by reflection and with design.' Again, he says, 'Every bird must, from the first time it hatches its eggs, draw the conclusion that young will also be produced from the eggs which it lays afterwards.' As if the instinct which induces it to hatch its first brood was not enough to induce it to hatch those which succeeded! Even more strange is his remark ${ }^{3}$ that ' it is undecided how far all birds, even before they begin to incubate themselves, obtain a knowledge of their origin from eggs by observing others incubating.'

Once more, with respect to that wonderful instinct which results in the production of imperfect females, or workers, to constitute the great mass of the inhabitants of a hive, the Professor again supposes the presence of true intellectimagining that the habit arose from some humble bee having been aided in the hard task of feeding all her grubs by certain workers accidentally produced.

'The insect must,' he says, ${ }^{4}$ 'have recognised this advantage afterwards; and ac rdingly reared similar workers intentionally by

1 P. 257.

P. 258.

3 P. 264.

4 P. 278. 
insufficient feeding. Another explanation which might be given is that certain individuals began to sacrifice themselves to the requirements of the community by neglecting to feed themselves to such an extent that their organs no longer attained their full development.'

He seems to attach no importance to the character thus assigned to our own highest powers. He adinits ${ }^{1}$ that on his view 'intelligence and reason become merely mechanical, but in a way which does not diminish the importance of instinct.' Most certainly it does not, nor have we the slightest desire to diminish its importance. But it becomes obvious on the slightest reflection that we are compelled to estimate instinct by means of reason, and that it is impossible to estimate reason by means of instinct. Reason is our only and ultimate standard in every judgment we make, and we know that the activity of our highest mental powers is certainly not an activity which is merely mechanical; then any theory which necessarily and logically results in the conclusion that our own highest powers are 'merely mechanical' is thereby refuted by a reductio ad absurdum.

But Professor Eimer's criticisms on the speculations of some other dreamers (the fabric of whose visions he considers baseless, as we do many of both theirs and his) are very noteworthy.

The question referred to is how, upon the principles of those he criticises, life, sensibility, intelligence, and volition, could ever come to be? This problem is made short work of by assuming that sensibility and will are possessed not only by every fragment of every living thing, but by every atom of every dead thing also-an assumption which we need hardly say is absolutely gratuitous, and is taken as proved on the implied argument, 'How otherwise should our system be true?'

1 P. 284. 


\section{Eimer on Growth and Inheritance}

Thus Haeckel explains ${ }^{1}$ the chemical attractions and repulsions of bodies by attributing to them definite inclinations which they possess the will and the power to obey by moving towards or away from one another.

"If the "will" of man ... seems free in contrast with the "fixed" will of the atoms, this is a deception caused by the contrast hetween the extremely complex voluntary motions of the former and the extremely simple voluntary motions of the latter. ... As the mass of the atom is indestructible and unchangeable, so the atomic soul inseparably connected therewith is eternal and imperishable. . . . This monistic conception of atoms is alone in harmony with the great laws of the "conservation of energy" and the "indestructibility of matter," which the natural philosophy of the present day rightly regards as its irremovable foundations.'

Now though Professor Eimer is as unreasonable as Haeckel in seeking to maintain ${ }^{2}$ a mere 'mechanical conception of the idea of will,' he nevertheless draws a very sound distinction between a faculty of mere irritability (as when upon a touch the squirting cucumber ejects its seeds) and a true power of sensation. It is true, as he says, that we have no unequivocal evidence that sensibility exists in any organism which does not possess nervous substance.

' The very fact,' he contends, ${ }^{3}$ ' that in animals a special nervous system, nerve fibres and nerve cells, have arisen, which are absent in plants, proves of itself that the reception and conduction of stimuli in animals must be quite different to those in plants. . . . For the single reason, then, that the substance which reacts to stimuli in animals, which in any case in the higher animals is the instrument of sensation and voluntary action, is quite peculiar to animals, it is allowable to infer that the two latter faculties belong to animals only. We might thus, in a sense, recur to the old aphorism of Linnæus: "Lapides crescunt, plantæ crescunt et vivunt, animalia crescunt, vivunt et sentiunt.",

He also gives a very interesting account ${ }^{4}$ of various move-

${ }^{1}$ Die Perigenesis der Plastidule oder die Wellenzeugung der Lebenstheilchen. Berlin.

2 P. 309.

${ }^{3}$ P. 310.

4 Pp. 312-314.

VOL. II. 
ments of very lowly organisms, which might, at first sight, be mistaken for voluntary movements. Thus, Myxomycetes, which, at one stage of its existence, seems to wander as an almost fluid mass of protoplasm, is an example of such lowly organisms. He tells us how its gradual, creeping motion is determined by the progressive drying up of the substance on which it rests, which causes it to be attracted to adjacent parts, which retain their moisture longer. Unequal distributions of warmth, or of oxygen, have similar effects. If its fluid substance, or 'plasmodium,' is brought in contact, on one side, with solutions of common salt, saltpetre, or carbonate of potash, it will withdraw from such dangerous vicinity, while infusions of tan, or dilute solutions of sugar, will attract it. It will also withdraw itself from light, and it has a truly wonderful faculty of avoiding harmful matter, traversing its supporting substance in all directions and taking up such materials as it may require.

But besides giving evidence in favour of the essential distinctness of sensitive from non-sensitive organisms, Professor Eimer makes some valuable remarks in opposition to the view that unicellular and multicellular organisms are so distinct as they have, we believe too hastily, been assumed to be. This distinctness is generally assumed to be so great that no structure formed from cells in the latter group can be really equivalent to any differentiation which can arise within a single cell. Those minute infusorians known as vorticellæ are each supported on a long stalk which, upon a very light stimulus, will suddenly coil upon itself, and so bring the vorticella attached to it near to the point where the stalk is itself attached. Now the vorticella, with its stalk, together consist but of one single cell. In all multicellular animals, organs of motion or muscles are formed from cells, and are equivalent to a greater or less number of such. It would seem, therefore, ${ }^{1}$ that a whole 
vorticella with its stalk could only be equivalent to one of the cellular elements whereof the muscular tissue of any multicellular animal is composed. Yet Professor Eimer does not doubt but that the protoplasm in the stalk of a vorticella is really equivalent to the muscular substance of higher animals, and he quotes Kühne ${ }^{1}$ to the effect that this particle of vorticella protoplasm 'behaves exactly like frog's muscle, and, even when isolated from the rest of the animal, can be made to contract, and even be tetanised, by the stimulus of variations of an electric current.' But whatever may be the degree of equivalence existing between such practically similar parts, we think the Professor is fully justified in asking," 'How could selection, or even sexual mixture, produce muscles at particular parts of the body where previously none were present? Selection and mixture can only deal with what is in existence.'

The most important part of the remaining portion of the book treats first of the evolution of the organs of sense, and secondly of the evolution of the whole organism by physical activities which are supposed not to be mysterious. We shall find, however, that these explanations, when even slightly analysed, turn out to be mere words or phrases, which either imply the existence of forces the Professor ignores, or are utterly impotent to suggest any real explanation whatever.

Thus he supposes the ultimate material constituents of the several sense-organs to have been derived from one common layer of cells placed on the external surface of supposed primitive and as yet actually insentient organisms. The most external layer came, and comes, first into contact with the outer world. 'All external stimuli acted first upon it. By the repeated incidence of stimuli this layer,' he tells $\mathrm{us}^{3}{ }^{3}$ ' must have become more and more fitted for their recep-

${ }^{1}$ Myologische Untersuchungen. Leipsic. $\quad{ }^{2}$ P. $328 . \quad{ }^{3}$ P. 332. 
tion, and subsequently for dealing with them, must have had their capacities exercised and strengthened.

To these representations we have no objection, provided that it be admitted that in such sentient organisms there must first be a latent power different from that possessed by purely non-sensitive organisms, such as Professor Eimer admits plants to be. But what is a 'different power'? It is and must be something dynamic and non-material. Let the existence of such an entity (one perfectly conceivable, though necessarily unimaginable) be allowed, and then we can understand that stimuli, and incipient activity thence resulting, may call forth into active exercise what before was but potential.

He says," later on, 'Only function could impress upon nervous, as on other cells, a definite morphological character.' Yet nothing can act before it is; but the dynamic agency, we affirm, can be understood as simultaneously giving rise both to morphological characters and physiological activities.

From this similarity of origin, common to the different sense-organs, he infers ${ }^{2}$ that all the external activities which stimulate diverse sense-organs in sich different manners ' may be but different qualities of one and the same stimulus, different forms of motion of external media - even the stimuli of taste and smell.' But all that need be inferred from such similarity as there is between our different organs of sense, is that the objective causes-the various activities -which act on such organs possess a similarity as regards their modes of action. It does not on that account really follow that sight and taste should be 'motion' any more than that motion and hearing should be really 'smell.' Our readiness to refer other activities to 'motion' is the simple and necessary result of our constant and universal experience of 'motion,' which cause it to be so much more easy to

$$
1 \text { P. } 342 .
$$

${ }^{8}$ P. 333. 
imagine. But our feeling of 'motion' is as purely and simply a feeling, as is any other sensation or group of sensations. It is the omission to recognise the necessary presence in every living being of a dynamic, immaterial principle of individuation, not numerically separate from it, but forming one substance with it, which renders Neo-Lamarekism, Neo1)arwinism, and all the other popular views as to the organic world, alike unsatisfactory and untenable. This is the truth to which we have antecedently more than once referred, and no healthy and sound biology is possible till it is recognised.

Professor Eimer may indeed be logically compelled to admit the existence of that immaterial, dynamic agency, the necessary existence of which was plain to Aristotle, unless he will forswear his own words. He affirms, ${ }^{1}$ in opposition to Weismann, that-

' the evolution of the characters of sense cells could not possibly have been produced by sexual mixture and selection-by variation of the germ cells-although I do not deny to the first two processes a share in the accomplishment of the result. Not variation of the germ cells which occurred by chance in a definite direction, but a definite capacity of modification, . . . has determined this modification.'

In fact, neither mere minute, accidental variations on the one hand, nor the play of external forces on the other, can of themselves give origin to definite organs. Let, however, similar kinds of dynamic immaterial agency be present in different organisms, and then we may expect to find similar structures evolved in similar cases-we may expect to find 'the independent origin of similar structures.'

And this is just what the Professor asserts ${ }^{2}$ he does find. Worms and jelly-fishes are different animals indeed, and neither can be said to be the parent of the other. But not only are the auditory organs which have been evolved in the two groups wonderfully alike, but those of some jelly-fishes

$$
{ }^{1} \text { P. } 336 .
$$$$
2 \text { P. } 337 .
$$ 
are more like those of certain worms than they are like the auditory organs of some other jelly-fishes; and, similarly, the auditory organs of certain worms are more like those of certain jelly-fishes than they are like the auditory organs of some other worms. To the wonderful resemblance which exists between the eyes of cuttle-fishes and true fishes it has been objected that the disposition of the retina in the one is the opposite to the disposition of the retina in the other, but we have learnt from Semper that in the slug Onchidium the retina, in these respects, agrees with that which exists in the eyes of fishes and other backboned animals-including, of course, ourselves.

The truth that similar structures have thus arisen independently tells with great force, as Professor Eimer says, ${ }^{1}$ 'against the prevailing fashion of dogmatically referring all similarities of form to blood-relationship.'

Experiments performed by him on jelly fishes ${ }^{2}$ lead him to the conclusion-

' that a single will can exist with a number of brains. . . . I have shown how the eight brains of Aurelia produce single movements; the impulse proceeds always from one of the brains, and passes immediately to the others-sometimes one, sometimes another originating the impulse-but this does not exclude the possibility of all eight acting at the same time; indeed, this is probably necessary for the production of certain movements.'

He adds as a conclusion (which may startle some readers) the assertion:-

'Whether in a given animal there are eight such central points of nervous activity or thousands-as many as there are nerve cells or cetoderm cells on the body surface-makes no difference.'

This assertion we have no more desire to contest than to support. We regard it as an interesting speculation, but not 1 P. 339. 2 P. 348. 
an important one for us. The position we take up is quite unaffected by it, and accords with either alternative.

His next contention - in favour of that belief in a universal unity which is the foundation of his system-is ${ }^{1}$ that-

' no fundamental distinction exists between the language formed by the voices of animals and human speech.'

Now we have no space left to develop our argument against this assertion; but there is the less need so to do as the question has quite recently been considered by us at great length, ${ }^{2}$ and in a manner which we hope is satisfactory and conclusive. Lest, however, our readers should imagine that we are at all disposed to ignore the power of animals in this direction, we quote with pleasure a passage cited $^{3}$ from Jäger in support of Eimer's position :-

'By means of looks, gestures, and sounds animals speak a very plain language, and it requires only a somewhat persevering attention to learn this language. . . The sound-language which most mammals and birds, and some reptiles, fishes, and insects possess, consists of cries expressing feelings, like the utterances of a child in its earliest years. The interjections of our word-language are the most closely related to the cries of sensation of animals. The cries of animals, however, have not merely the value of interjections, they are something more. Thus the animal can express several sensations by modification of its voice, by modulation of its tones. Thereby animals are able to communicate their sensations and conditions even during the night when they cannot see each other's gestures.

As to certain monkeys, J. von Fischer is quoted as saying:-

' I understood the sound-language of each of my monkeys, and knew exactly thereby the state of its feelings at any particular time.

1 P. 374.

${ }^{2}$ See The Origin of Human Reason. Kegan Paul, Trench, Trübner \& Co. 1889.

3 P. 368. 
... When he desired a thing, he cried "oh," or "o-oh," in the latter case the second syllable being higher than the first. At the same time he laid his ears close to his head, drew back his brows, and pouted his lips. Joy and pleasure he expressed by a grunting or gurgling throat-sound. At the same time he laid back his ears for a short time, drew back all the skin of his head for a moment with ir jerk, his eyebrows being thus also drawn back, and stretched out his mouth with the lips narrowed. In extreme pleasurable excitement he disclosed his teeth as far back as the middle of the molar series, and uttered a slight tittering sound like "ki ki ki," and so on.

As to all this we will only remark that it is improper and misleading to describe inarticulate sounds by articulate expression, such as ' ki ki ki.'

The truth concerning the real nature of brute language is well expressed by Schleicher, although he takes what we regard as a mistaken view of the origin of human speech. $\mathrm{He}$ says :-

'Sound-gestures, in some cases highly developed sound-gestures, for the direct expression of its feelings and desires, the animal possesses, and by means of these, or by means of other gestures, animals are able to communicate their feelings to one another. Accordingly, it is usual to talk of the speech of animals. But the faculty of directly expressing thought by means of sound is possessed by no animal, and this alone is the meaning of speech. How fully this is in fact recognised in our ordinary consciousness is shown by the consideration that an ape endowed with speech, or even an animal utterly different from man externally, if it possesses the power of speech would be regarded by us as a man.' ${ }^{1}$

If it truly possessed the power of speech-that is, if it had the power of expressing abstract ideas, though only by gesture-it would properly be so regarded, for it would plainly be 'a rational animal.' But it might make use of articulate sounds like a parrot, or it might have learned to use articulate sounds as a dog begs, and not otherwise. In that case

$$
{ }^{1} \text { P. } 370 .
$$


its language, though articulate, would be but a sign of its feelings, and not true speech.

Highly unreasonable, then, are Professor Eimer's remarks on this subject. A blackbird having been said ${ }^{1}$ to utter the cry 'dag, dag, dag,' as a warning cry, and the ancient German expression for ' $I$ ' having been declared ${ }^{2}$ to have been 'dha, Alla, ma', our Professor remarks : ${ }^{3}$ 'I think the above completely justifies me in speaking of the sounds uttered by blackbirds as their language. "Dag, dag, dag," is as good a sound as "dha, dha, dha."” But the blackbird did not really say 'dag' at all, and the man did not say 'dha, dha, dha,' but 'dha, dha, ma,' which is a distinct manifestation of highly abstract thought-the thought of the Ego as existing and active.

We come, last of all, to Professor Eimer's treatment of 'the idea of organic growth'- the growth of the individual and the growth of the species, or phyletic growth. Of growth itself he has formed a somewhat peculiar conception, since he says :4 'Growth is by no means necessarily the result of the assimilation of food: the action of any external stimuli is capable of causing changes in the position of the particles of the body, and thereby of causing growth in my sense of that term.' Surely the enlargement of a bladder due to heat expanding the air within it cannot justly be called 'growth'? The expression 'change of shape' would become superfluous if every such change could be called 'growth.' Change with auginentation of substance and change without augmentation of substance are two distinct ideas, and require to be denoted by two different terms; and it is at least convenient to call the former by the term commonly accepted to denote itnamely, by the term 'growth.'

In speaking ${ }^{5}$ of the effect of physical forces on organisms, he asks, 'Is it not the force of gravity which determines the
${ }^{1}$ P. 367.
${ }^{2}$ P. 372.
${ }^{3}$ P. 373.
${ }^{4}$ P. 180.
${ }^{5}$ P. 385. 
form of roots and causes them to grow towards the centre of the earth?' That it has acted and acts therein we do not question; but we deny that it can be termed the determinating agency, and we deny it on the strength of Professor Eimer's own words. He tells us ${ }^{1}$ that 'Vöchting hung up a twig of willow in a position the reverse of the natural, in a vessel where it was exposed to moisture and the other conditions favourable to growth. This twig produced roots not only at the lower end, where their development was favoured by gravity, but also, and in superior numbers, at the upper end.'

In that plant of the Cactus tribe named Lepismium radicans, roots will be produced on any part of its sprouts from which light is excluded. Nevertheless, as a rule, roots are thrown out from the underside of plants only, as we should naturally anticipate.

With respect to the re-formation of parts removed-extraordinary instances of the process of repair-Professor Eimer remarks :- ${ }^{2}$

"The old explanation was that it was due to the "formative tendency," and this was deemed sufficient. We may still use the same term, provided that we get rid of the meaning which the earlier school attached to it, namely, that of a spontaneous impulse more or less independent of matter. If we guard against this, and employ the term in the sense of the action of definitely directed forces contained in the material of the organism, then there is nothing to be said against it.'

But the earlier school, to which we presume Professor Eimer refers, did not regard such impulse as in any way 'independent of matter,' but as absolutely dependent upon matter for its manifestation. It held, as we hold, no more than what Professor Eimer must, if he is logical, mean when

${ }^{1}$ P. 400.

2 P. 393. 
he speaks ${ }^{1}$ of 'inherited definite tendencies' as alone constituting 'the specific qualities of the various species.' But though thus occasionally lapsing into such dynamical expressions with respect to vital actions, he ordinarily follows the prevailing school in relying on mere words as explanations. Thus, he tells us, ${ }^{2}$ "it has come about that heredity not only constitutes this unity by development, but also endeavours to reconstitute it after injury.' 'Heredity' is, of course, a term now current; but in what is it really clearer or more explanatory than the term nisus formativus? What is there really more intelligible in his own expressions, ${ }^{3}$ 'growth tendency' and 'formative power'? Again, he tells us that a mutilated whole is reformed because in each of its particles 'there is something of the tendency to form a whole;' and he speaks of ' a tendency to develop into the whole by 'growth' being 'impressed upon the several particles of an organism by heredity.' Thus heredity is personified and made an active agent, regardless of the fact that it is a mere abstract term denoting various phenomena. An actual, concrete, dynamic, immaterial agency, immanent in every living organism, is, however, a conception which (be it true or false) does at least serve to explain the phenomena of growth, repair, development, and phyletic evolution. That processes of repair are not mere processes of vital crystallisation taking part upon a 'polarised terminal surface' is, to our mind, sufficiently demonstrated by the differences of tissue and of internal arrangements of parts which may be found in a reformed part, externally like its normal predecessor-as, e.g., in a re-formed lizard's tail. That normal development is due to nothing of the kind is also shown by the fact that in the developing embryo there is no 'polarised terminal surface,' as there is the stump of a tail or limb which has been removed.
1 P. 386.
2 P. 394.
${ }^{3}$ P. 407. 
Such development and such re-growth are not to be explained as Professor Eimer would explain them. He speaks only of the establishment 'in every developing and every adult organism' of ' a relation of the particles to one another, which finds its expression in their striving to form themselves into the whole, and to maintain or re-establish the co-ordinated whole.' The striving of separate particles, each governed only by its own innate forces, can never serve to explain their definite, mutual, orderly collocation as one organic whole. Try as we may, the profoundly rational conception of the great Macedonian philosopher will again and again force itself upon the unprejudiced mind, for the explanation it affords is a natural explanation, and in philosophy no less than in the conduct of human life we may indeed say, 'Naturam expellas furca, tamen usque recurret.'

The controversy between the Professors of Tübingen and Freiburg is to us a very interesting one. So far Professor Eimer appears, in our judgment, to have, on the whole, the best of the dispute. But, effective as he is in his attack upon Professor Weismann's doctrines, he exhibits marvellously little capability of defence. The doctrine that merely minute haphazard changes in the molecular constitution of germplasm are sufficient to account for all the beauty, all the variety, all the adaptations, and all the varieties of feeling, habit, and instinct to be found in the living world, he indeed triumphantly demolishes. But his attempt to show that all these powers, harmonies, and beauties are due to nothing but the hereditary transmission of the action of the environment he fails, almost ludicrously, to establish. However thoroughly the faith of the Neo-Darwinians may be overthrown, we certainly shall not thereby be led to take so retrograde a step as would be a return to the old discredited hypothesis of Lamarck and the 'Vestiges of Creation.' Nevertheless we 
are thankful to Professor Eimer for his labours. His book is full of interesting matter, and we can cordially recommend its perusal to such of our readers as are interested in those biological speculations which have become one of the most notable features of the latter half of the nineteenth century. 
0 




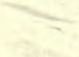



QH

367

M5

v.2

Biological

\& Medical
Mivart, St. George Jacksor Essays and criticisms

\section{PLEASE DO NOT REMOVE} CARDS OR SLIPS FROM THIS POCKET

\section{UNIVERSITY OF TORONTO LIBRARY}




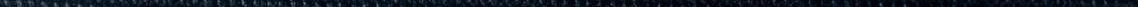

